


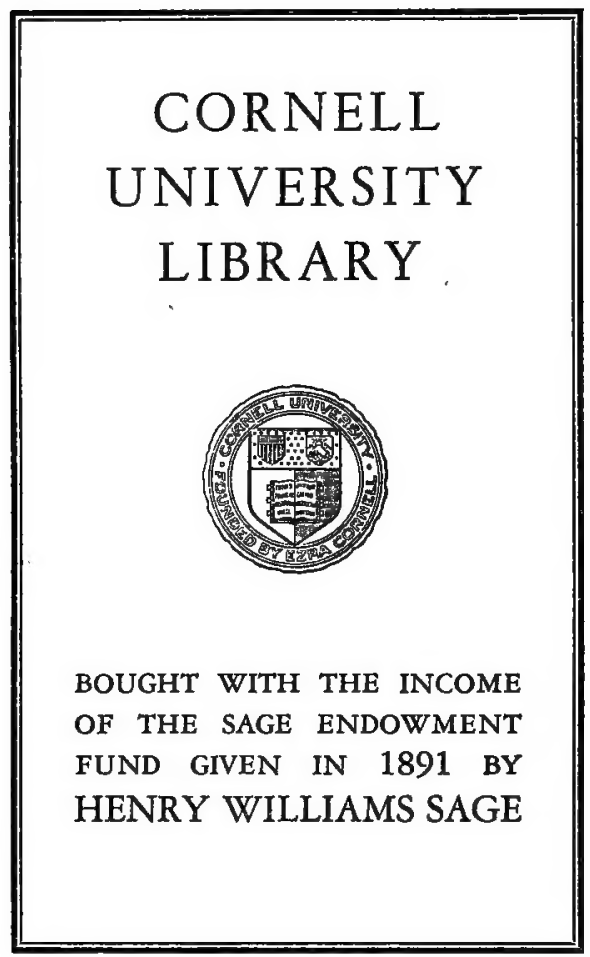


CL 607 Cornell University Library

Catalogue of vertebrates found in New Je

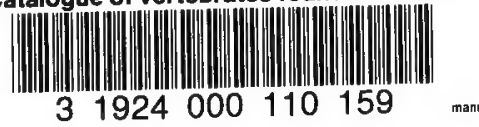




\section{Cornell University Library}

The original of this book is in the Cornell University Library.

There are no known copyright restrictions in the United States on the use of the text.

http://www.archive.org/details/cu31924000110159 






\section{DESCRIPTIVE CATALOGUE OF THE VERTEBRATES OF NEW JERSEY.}

BY JULIUS NELSON, PH.D. 



\section{DESCRIPTIVE CATALOGUE \\ OF THE VERTEBRATES OF NEW JERSEY.}

(A revision of Dr. Abbott's Catalogue of 1868.)

PREPARED BY JULIUS NELSON, PH.D.

INTRODUCTION.

At the request of the late Dr. Cook, I herewith present a revision of Dr. Charles C. Abbott's Catalogue of the Vertebrated Animals of New Jersey, published as "Appendix E, Geology of New Jersey, 1868."

Owing to the numerous changes in nomenclature and classification which have been made within the last twenty years, the labor of merely revising the synonymy of 'Dr. Abbott's Catalogue has been great.

Before publishing his Catalogue, Dr. Abbott spent several years in acquainting himself particularly with the fauna of the State. The valuable knowledge thus obtained, he appended as notes to the name of each species. It bas been thought best to retain this feature in the new Catalogue. Accordingly, all these notes have been inserted in quotation marks without change, except such as was called for in the inter-references among the species, due to their new arrangement. Wherever statements occur of a personal character or such as are given upon the authority of Dr. Abbott, and the truth of which I am able neither to controvert nor to confirm, I have thought best to add the initials [C. C. A.] at the close of the paragraph containing such statements.

To increase the usefulness of the Catalogue $I$ have added a description of each species, with particular reference to features distinguishing it from its allies, for purposes of identification. This seemed especially needful for species that are often confounded by the general observer. These descriptions have been made more complete for the birds and fishes, because these two groups are most numerous in species, are of special interest to the sportsman and angler, and con- 
tain many forms which are only transient visitors to our State. The diagnoses have been prepared for persons of general education who may be interested in identifying species, rather than for the scientific specialist. So far as possible, technical terms and anatomical characteristics have been avoided, although it was impossible to omit them entirely. Such terms are defined in any standard dictionary, and the symbols and abbreviations used are explained at the close of this Catalogue.

Professor Jordan's excellent "Manual of the Vertebrates of the Northern United States"* has been used in the preparation of the lists of Mammals, Reptiles and Amphibia. In numerous instances, the language of the Manual has been copied verbatim or nearly so, but much valuable matter has been necessarily omitted. The reader who desires fuller information is referred to the above work. For the birds, the recently-issued "Manual of the Birds of North America," by Robert Ridgway, has been used more freely, but in rare instances have any sentences been copied verbatim, and only a small portion of each of Mr. Ridgway's full descriptions has been used. But Prof. Jordan's descriptions have been used wherever they appeared satisfactory to our purpose.

For the fishes, free use has been made of Jordan and Gilbert's "Synopsis of the Fishes of North America" (Smithsonian Collections, Vol. XXIV., 1883).

The general arrangement of the generic, specific and common names of the groups of animals which was adopted by Dr. Abbott has been followed, except that in giving the scientific name of the species the generic name is repeated by initial only. The names of authors, usually abbreviated-see list of abbreviations at close of Catalogueare added in Roman type after the scientific name of the genus and the species or variety. Then come synonyms, added in brackets, and when following a generic term are generic names, and usually are of specific value if occurring after the specific designation; but it often happens that a particular species has been referred to several different genera, and has had various specific names given by different authors that are now to be set aside; and, furthermore, a succeeding species belonging to the same genus as now adopted has been referred to another set of genera different from those applied to the former species. In all such cases the specific name is followed by the series

\footnotetext{
* Fourth edition. The fifth edition came to hand too late for use in this work.
} 
of generic and specific designations in parentheses-the generic terms being placed first, beginning with capitals, while the specific terms do not begin with capitals. No attempt has been made to indicate which specific terms have been coupled with each generic term.* In some cases every specific term is to be associated with each generic term. But the simple list of the different generic and specific terms that have been applied to an animal seemed sufficient for the general reader. After the scientific designations follow the common names, and then the descriptions, and finally Dr. Abbott's notes, to which additions have been made by the writer in several instances.

In this work the Classes of Vertebrata are arranged in what may be called the inverse order-that is, proceeding from the highest to the lowest.

\section{Mammals. \\ Birds. \\ REPTILES. \\ Amphibians. \\ Fishes.}

Of these, the Orders, Families, \&c., of Mammals, Reptiles and Amphibians also follow the inverse order of arrangement, as in Jordan's Manual.

The Orders of Birds are also arranged inversely, but the Families under each Order follow the plan of Ridgway's Manual. The fishes are arranged throughout according to the natural order, from lowest to highest, as in Jordan and Gilbert's "Synopsis."

It is hoped that persons using this Catalogue will communicate with the Biologist of Rutgers College, whenever specimens are found that do not appear to be in this list. Very nearly all the rare forms have been included, but it would unduly extend the work to include every migratory species that may, by some extremely infrequent accident, visit our State. So many of these accidental species have been included that the chance that any species will be found that are not described in this list, appears to the writer to be very small. This remark refers to forms well known elsewhere, but does not refer to species that are not thoroughly diagnosed, even where they are quite abundant. We will now give an example of such a case.

Among mammals it is particularly desirable to gain information concerning the number of species of shrew mice and their worth or

* To some extent these connections are shown in the index. 
destructiveness, and similarly of the field mice. The two are often confounded, although they belong to two separate orders, the Insectivora and Rodentia, respectively. The general characteristics of the former make them insect-eaters, while the latter are more destructive to grain, roots, fruits, \&c. In any individual case it is desirable to know if the good or bad qualities of the group are exemplified in the particular species.

So many of the birds are migratory and likely to be met with only temporarily, that we encounter peculiar difficulties in respect to making a catalogue of them. Yet, to the sportsman the migratory birds are of the greatest interest, and cannot be left out.

The reptiles form a class that is easily exterminated in a eivilized community, and yet there are remote hiding-places in swamps and mountains where such forms may linger a long time and only rarely be seen. While, to the ordinary observation, certain species would be practically extinct, it would be rash to say that they are actually extinct. The list must therefore be considered incomplete in this respect, and information concerning snakes and other reptiles that may be seen, not included in the present list, is earnestly desired.

It is the desire of the Biologist to make a collection of the fishes of New Jersey, in connection with which group of animals so much of the practical and scientific work of the biological department of the Experiment Station will lie. All public-spirited persons who are interested in having at the Station a representation of the various fishes of their locality are invited to send specimens to the Station. Such specimens can be sent packed in dry salt (in most instances), in receptacles convenient for the transport of fish. In cold weather no salt is needed.

The following synopsis (which may serve as a table of contents), shows the order in which the groups of Vertebrates are arranged in the Catalogue which follows, and the page where the consideration of each begins:

Class mammalía.

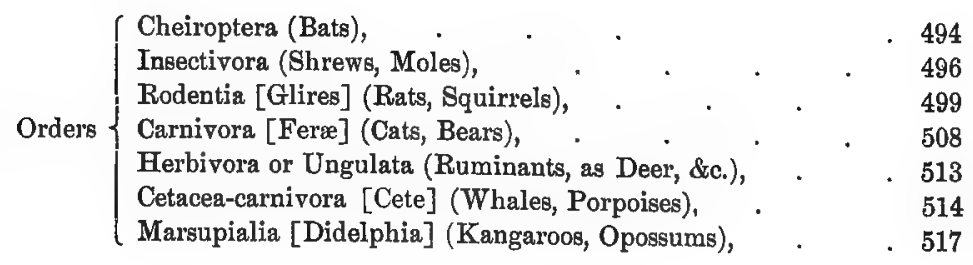


CLASS AVES (Birds).

8. Sc.ANsores (Climbing Birds).

( Pici (Woodpeckers), . . . . 518

Orders Cuculi [Coccyges] (Cuckoos, Kingfishers), . 522

[ Cypseli [Macrochires] (Swifts, Humming-birds), — 523

8. INSESSORers (Porching Birds).

Orders $\{$ Passeres (Sparrows, Crows, Larks, Swallows, \&c.), . . 525

Raptatores [Raptores] (Owls, Eagles, Birds of prey), . . 573

3 CURsores (Running Birds).

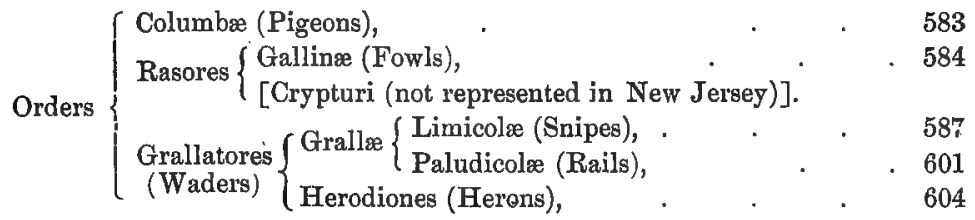

\& NATAToRes (Swimming Birds).

Orders $\begin{cases}\text { Lamellirostres } \begin{cases}\text { Anseres (Ducks, Geese), } \\ \text { [Odontoglossæ (Flamingoes)]. }\end{cases} & 609 \\ \text { Steganopodes [Stegani] (Pelicans, Cormorants), } & 621 \\ \text { Longipennati [Cecomorphæ] }\left\{\begin{array}{l}\text { Tubinares (Albatrosses), } \\ \text { Longipennes (Gulls), }\end{array}\right. & 623 \\ \text { Brevipennati [Pygopodes] }\left\{\begin{array}{l}\text { [Impennes (Penguins)]. } \\ \text { Urinatores (Auks, Grebes, \&c.), }\end{array}\right. & 631\end{cases}$

Class REPTILIA.

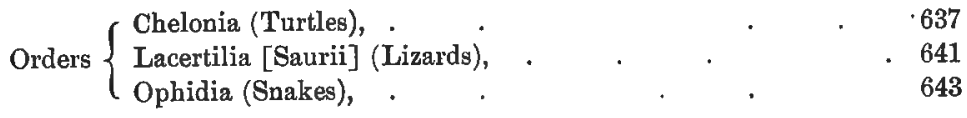

CLASS AMPHIBIA [Batrachia].

Orders $\left\{\begin{array}{l}\text { Anoura, or Anura (Frogs), } \\ \text { Urodelo }\end{array}\right.$

Cuass PISCES (Fishes).

Sub-Class Marsipobranchir [Cyclostomi].

Orders $\left\{\begin{array}{l}\text { Hyperotreta (Hag-fishes), } \\ \text { Hyperoartia (Lampreys), }\end{array}\right.$.

Sub-Class Elasmobranchir (Selachians).

\& Piagiostomi.

Orders $\left\{\begin{array}{llllll}\text { Squalides or Squali [Selachii] (Sharks), } & . & & & & 659 \\ \text { Rajides or Raiæ (Rays), } & . & . & 663\end{array}\right.$

Sub-Class Ganomer.

\& Chondrostei.

Order-Glaniostomi (Sturgeons), . $\quad . \quad$. . . . . $\quad .668$ 
of a tree, generally sheltered from the sun's light. The females produce their young towards the end of June, three to five at a litter. In the winter they lie dormant, generally choosing a hollow tree for their winter quarters, many individuals occupying the same tree."

V. subulatus, var. lucifugus, Le C. Blunt-nosed Bat.

In this case, and in that of $V$. fusous, these varieties which stand as distinct species in the old Catalogue, perhaps scarcely merit the special designation we have given them.

"Appears to be more common during some summers than others. After a cold northeast storm in July, and while the air was still unseasonably cool, a 'festoon' of bats was found by the author, containing nine in all, two of which were of this species. These 'festoons' are not unfrequently met with during cool weather." $-[$ C. C. A.]

\section{Order INSECTIVORA.}

\section{Family SORICIDE.}

Shrews.

SOREX, L.

S. forsteri, Rich. Long-tailed Shrew.

Tail two-thirds length of head and body; snout slender; ears small. Length, $4 \frac{1}{2}$ inehes.

"Not abundant, and have met with it only in the northern counties of the State, and once in Mercer county. Lives generally near water, and like the preceding, burrows a short distance below the sod, for a place of refuge and a nest. Feeds on larvæ of insects and on crickets." - [C. C. A.]

\section{BLARINA, Gray.}

B. brevicauda, Say. (talpoides, Gap.) [De Kay's Shrew.] Shorttailed Shrew. Mole Shrew.

Fur short and coarse; color dark ashy gray. Length, $4 \frac{1}{2}$ inches. 
"Frequents the banks of streams. Its nest is quite under the ground, smoothly lined with fine grass. Females litter in May and July. Feeds wholly on worms, larvæ of insects, and similar food. When disturbed, will dive readily, and swims easily. Probably devours the ova of the sunfish. Abundant."

There are probably other species of Shrews or Shrew-mice besides those noted above. Farmers should be on the lookout for the following (specimens of which will be gladly received at the Station):

SOREX.

S. platyrhinus, De $\mathrm{K}$.

\& Teeth colored, $32-2 \frac{0}{2}$ (Sorex).

Ears very large for a shrew ; tail scant-haired; color chestnutty. Length, $3 \frac{3}{4}$ inches; tail, $1 \frac{1}{2}$ inches.

S. cooperi, Bach.

Same as preceding, except ears a little smaller and color chestnut brown.

S. personatus, Geof.

Smallest of our shrews. Length, $2 \frac{3}{4}$ inches; tail, 1 inch. Color and ears as in the preceding.

\& Teeth, 30-1 $\frac{1}{1} \frac{8}{2}$ (Microsorex, Baird).

S. hoyi, Bd. Hoy's Shrew:

Very small and slender; ears large; olive brown. Length, 3 inches ; tail, $1 \frac{1}{4}$ inches.

\section{BLARINA.}

Short-tailed Shrews.

B. angusticeps, $\mathrm{Bd}$.

$$
\text { \& Teeth, 32-120 (Blarina). }
$$

Size intermediate; skull narrow; color uniformly leaden. Length, $3 \frac{1}{2}$ inches; tail, 1 inch.

$$
\text { z Toeth, 30-1星 (Soriciscus, Coues). }
$$

B. parva, Say (cinerea, Bach.)

Body stout ; iron gray, with brown gloss. Length, $3 \frac{1}{4}$ inches ; tail, $\frac{3}{4}$ inch. 


\section{Family TALPID}

Moles.

Moles differ from shrews in having more numerous teeth, in the presence of canines, in having concealed eyes, and in the peculiar development of the fore legs, which are short, stout and adapted for digging.

\section{SOALOPS, OUV.}

S. aquaticus, L. Common Mole.

Dark leaden color, paler below; feet full webbed; eyes not covered by skin ; tail short, nearly naked. 36 teeth.

"Common everywhere, provided the soil is loose enough to permit its subterranean travels. Is probably more abundant in the moist meadow lands than in the high and dryer sections. Feeds almost wholly upon earth-worms, and destroys so many that unless they (the moles) are very abundant, are more useful than otherwise. Mroles arrange their nests at a somewhat greater depth than they usually burrow at. The young are littered in May, seldom more than three being born at one littering. The prevalent idea that moles are blind is erroneous."

\section{SOAPANUS, Pom.}

(Scalops-Abbott's Catalogue.)

S. 'breweri, Bach. Hairy-tailed Mole.

Color dark leaden, with brown gloss. Tail short and very hairy. 44 teeth.

"Is much less abundant than the preceding, to which it bears a great resemblance. This mole seems to prefer wet, low grounds, even more than the preceding species, and burrows somewhat deeper. The nests are also further below the surface. They feed almost wholly upon the common earth-worm, and when placed in a box with a quantity of worms, they have been known to kill themselves by over-eating."

CONDYLURA, Illig.

C. cristata, L. Star-nosed Mole.

Color blackish; tail nearly as long as body. Liong nose, fringed at end with a circle of fleshy projections. 44 teeth. 
"Not at all abundant." Prefers moist land, and is more frequently found burrowing in the banks of streams than elsewhere. Does not differ materially in its habits from the more common species. Is more frequently met with in the central than the northern or southern sections of the State."

\section{Order RODENTIA.}

\section{Family SCIURID}

\section{Squirrels.}

"The true squirrel is arboreal. His home is in the trees, and his legitimate food their fruits and buds. Should he go to the ground, it is only in search of food; and this obtained, he returns to his airy dwelling-place. Here in summer he builds him a nest of leaves, taken from the branches at hand, and in a hole in the same tree, or in one that he can attain by springing from branch to branch without going to the ground, he has a more secure retreat, to which he can retire during inclement weather, or escape the attacks of an enemy, and in which the young are generally reared.

" 'This class of squirrels possesses a muscular but light and graceful form, with the toes long and the nails strong and sharp, by which they are enabled to climb trees and take long leaps among the branches with wonderful ease. In these leaps, they are also aided by their large and bushy tails, which serve as rudders to steer by. They use their fore feet as hands, seizing their food with them, and stand upon their hind feet when eating. On the ground they either run or move by springs made mainly by the hind legs. Unlike most of the order, they move about by day, and keep in their retreats at night, to which they also retire for a few hours during the middle of the day. Though their food is properly vegetable, squirrels are known to eat insects. By a slighter departure from their natural food, they exhibit a fondness for corn, and more rarely wheat and other grains, which is highly prejudicial to their good standing in a community of farmers. In fact, these animals are much more injurious than is generally known.'-Kennicott. So far as the latter clauses of the above 
quotation are concerned, they are scarcely applicable to New Jersey, for no species is at present so abundant as to render its 'grain depredations' appreciable. Partly on account of a general cutting off of large timber, and largely in consequence of the persistent shooting, at all times of the year, the squirrels have become, we may almost say, uncommon. In no county of the State could five hundred probably be found, during the proper shooting season. As they are, in so small a degree, insectivorous, it is perhaps of little moment whether they be numerous or otherwise, and probably their absence is more than compensated for by the true insectivorous birds (whose nests are frequently destroyed by squirrels), which are, when undisturbed by squirrels or men, really valuable beyond calculation."-[C. C. A.]

\section{SOIUROS, L.}

s. niger, L., var. cinereus. Fox Squirrel.

No cheek pouches; tail bushy, as long as body; ears long; no black stripes; color rusty gray, but very variable. Length, 26 inches; tail, 14 inches. The two following species of Abbott's. Catalogue are merely varieties of $S$. niger.

"This squirrel is not an abundant species in the State, and is the largest of the squirrel tribe found with us. A pair or two, when this species is met with, are found inhabiting large trees, and waging determined war with the hudsonius and striatus, also with the following species. In Mercer county specimens of this squirrel have been quite frequently met with during the past. three years. They seem to prefer a clump of large shell-bark hickories with open ground about them, and do not wander far from the tree containing their nest. Are occasionally seen during a warm spell of weather in winter."

B. migratorius (Abbott's Catalogue). Gray and Black Squirrel. '

A variety of $S$. niger.

"A greater number of this species are to be found in New Jersey than of the preceding, but as it frequents deep swamps and beavily-timbered tracts, away from houses, it is not more frequently seen in every-day life, and appears no more abundant. It is nowhere sufficiently numerous to be destructive to any extent." 
S. niger, L. (Abbott's Catalogue.) Black Squirrel.

Consider this as var. niger of $S$. niger, above.

"Very rarely met with, although probably only a variety of the preceding, which is an abundant species. Have seen but two specimens, both taken in Passaic county in December, 1860."

S. carolinensis, Auct. Gray Squirrel, Black Squirrel.

Varies from grizzly yellowish gray to pure black. Length, 24 inches; tail, 13 inches.

"It is not improbable that this, a southern species, may be occasionally met with in New Jersey, as one specimen has met my notice, known to have been shot in Essex county. There is a probability, however, of its having been a caged squirrel, escaped from its owner."

S. hudsonius, Pal. Chickadee. Red Squirrel. Chickaree.

Rusty red. Length, 14 inches; tail, $6 \frac{1}{2}$ inches.

"In many portions of the State this little squirrel, formerly very abundant, has become quite scarce. Such is the case throughout Mercer county in a marked degree. Before the large pine tracts in the southern counties were cut off, it was there found abundantly. Occasionally burrows quite deeply among the roots of trees. Lays up large stocks of food for winter use, and during this season is as lively as in midsummer."

\section{SCIUROPTERUS, CuV.}

(Pteromys, Cuv.)

S. volucella, Pal. Flying Squirrel.

Yellowish brown, creamy white below; a furred membrane extends along the sides from the fore to the hind legs. Tail flattened and densely furred.

"Quite common. Found only among large trees, especially large nut-bearing species. During the day they lie quietly in the hollow of a partially-decayed tree-frequently a balf dozen together-and as the sun goes down make their appearance, sailing about from branch to branch, and seldom coming to the ground. The females produce two litters during the summer, three to five the usual number. The nests are in hollow trees, and occasionally a deserted bird's nest is occupied. The food of this species is that of squirrels generally, and unlike them, a 
certain amount is stored away in autumn for winter use, duringwhich season they are very active. When barns are so situated that they can be reached by this species without their being compelled to travel over the ground, these squirrels are occasionally found in the mows, although it is not probable that the females: ever make their nests there."

\section{TAMIAS, Illig.}

T. striatus, L. Ground Squirrel. Chipmunk.

With 3 to 5 black stripes along the back, with cheek pouches and with the tail not bushy, but shorter than body. Length, 11 inches; tail, $4 \frac{1}{2}$ inches.

"Very abundant, and although a certain amount of yellow corn is eaten by them, are an inoffensive species. Live in burrows, and remain on the ground, or run along fences. They store up many nuts for winter use, and by the middle of October have generally crept into their burrows, where they remain in a state of semi-hibernation. Very rarely met with during the winter, even in long-continued mild weather."

\section{ARCTOMYs, Ichr.}

A. monax, L. Ground-hog. Marmot. Woodchuck.

Thumb rudimentary; soles naked; grizzly gray to blackish. Body large, thick set.

"Very abundant in certain localities and very seldom met. with in others throughout the State. The author has seen twelve killed along the bluffy banks of Crosswicks Creek, in Ocean county, during a three hours' hunt. Ground-hogs burrow very deeply, in open fields, on hill-sides, and in heavy timber land, though most frequently in open positions, so that when out of its burrows, the animal can see well about it. They are very wild and watchful, and never wander very far from their holes. The females have but one litter in a year, generally as early as April, and the young are always sufficiently grown by autumn to take care of themselves. Ground-hogs, or woodchucks, are strictly herbivorous, and do more damage in their visits to clover fields than by any other habit. When their burrows are near gardens, they will occasionally enter the gardens and eat largely 
of the vegetables there planted-peas and lima beans especially. Although not apparently a favorite locality, they burrow frequently on the banks of streams but little elevated." Besides, by means of trapping, woodchucks may be killed by putting a handful of rags, upon which a tablespoonful of bisulphide of carbon has been poured, into their burrows, and closing the opening by means of a sod.

\section{Family CASTORID}

\section{Beavers.}

Aquatic rodents of large size; fore feet with five distinct toes and claws; hind feet webbed; tail broad, flat and scaly.

\section{CASTOR.}

C. fiber; L. (canadensis.) Beaver.

"Probably no longer found in the State, but may possibly. still exist in very limited numbers about the northern boundary line. It was found in Cape May county twenty-five years ago occasionally, but in all probability has ceased to exist there. Was formerly very abundant, especially along the Assanpink Creek, Mercer county" (1868).-[C. C. A.]

\section{Family ZAPODIDA.}

\section{ZAPUS, Coues.}

(Jaculus, Wagl.)

Z. hudsonius, Zim. Jumping Mouse.

Yellowish brown; variable. Hind legs very long; fore legs short.

"Not very abundant. Frequents woods, but never goes very far from open ground. Occasionally it burrows, but not deeply, making a nest of fine grass. More frequently the nest is beneath the bark of a decayed tree. The young number from three to five in a litter, two litters generally being produced. Their 
food consists largely of seeds of plants and nuts. The 'chinkapin' or dwarf-chestnut they are extravagantly fond of, and they appear to store up quantities for winter use, but as they hibernate the nuts are not intended for such use, but are their 'stand-by' during November and so much of December as is sufficiently mild to warrant their remaining above the sod, for when it becomes really cold they burrow quite deeply down. They eat, too, little grain, and are too little abundant to be offensive." When animals are rare, it is a shame to wantonly destroy them.

\section{Family MURID Ż.}

Mice.

MUS, L.

M. decumanus, Pal. Brown Rat. Norway Rat.

Tail scaly, shorter than head and body; feet dusky white; fur mixed with stiff hairs. Introduced into America about 1775.

"Everywhere abundant, troublesome and boldly impudent. Very frequently met with in fields, burrowing and otherwise living as a strictly wild species. Their burrows are often very extensive, tortuous and deep, one large chamber frequently having several entries leading to it. They feed largely on grain when accessible, but are omnivorous."

M. rattus, L. Black Rat.

Tail not shorter than head and body ; feet brown. Introduced into America about 1544, but now giving way to the preceding.

"Formerly an abundant species-is now nearly, if not quite extinct. The author has met with but a single specimen, which was taken in Essex county in 1846 and preserved as a curiosity." - [C. C. A. $]$

M. musculus, L. Mouse.

"Abundant at all times and under all circumstances. More than it is generally believed of this species live out of doors. When thus living, they burrow quite extensively, generally under the shelter of corn-shocks, and still more frequently about the roots of trees, especially trees standing on the borders of fields. It lays up quite large stores of grain for its winter use." 


\section{NEOTOMA, Say.}

N. floridana, S. Wood Rat.

Tail scantily hairy ; feet white, soles hairy. Length, 14 inches; tail, 6 inches. Should not be confounded with the brown rat, which bas naked soles. This species ranges from the Gulf States to Massachusetts, and probably occurs in New Jersey.

\section{HESPEROMYS, Wat.}

H. leucopus, Raf. White-footed Mouse. Deer Mouse.

Yellowish brown; tail bicolor, closely hairy, about as long as head and body; $€$ ars large.

"Quite abundant, and a most interesting little animal. Frequently confounded with the 'jumping mouse,' but is easily distinguished by its lighter color and shorter tail. Found wholly in woods, living, nesting and gathering its winter store from the trees of the forest almost entirely. When grain-fields are skirted by timber land, they make incursions and gather corn and buckwheat, but do not travel any distance to secure grain if chestnuts and acorns are attainable in the woods. Do not hibernate. They build a nest not unlike a bird's nest, or use a deserted bird's nest. Three litters annually."

H. palustris, Har. Rice-field Mouse.

Blackish and ashy above, paler below ; fur harsh and com-' pact. A large, rat-like species of the Southern States, possibly likely to occur in Southern New Jersey.

\section{ARVICOLA, Lac.}

A. pennsylvanicus, Ord. (riparia.) Meadow Mouse.

Fore claws not longer than hind claws. Tail $\frac{1}{3}$ length of head and body, or more.

"The 'meadow mouse' of New Jersey. This species is quite abundant, and as its common name would suggest, lives almost - wholly in marshy, meadow lands. They burrow generally beneath the roots of a small bush or tree, and occasionally in the decayed stump of a tree. They are also found in hollow, 
prostrate trees. The females have generally three litters during the spring and summer, probably a fourth. Do not libernate. Feed on seeds of grasses and some grain, and lay up considerable stores for winter use. Is very seldom met with in woods, and scarcely more frequent is it in grain-fields."

A. pinetorum, Le C. Field Mouse. Pine Mouse.

Tail $\frac{1}{4}$ length of head and body.

"Abundant. Frequents high and dry fields, and burrows and lives more in corn-fields than other localities. During the winter its nest is generally found under a fence, and very frequently close to the fence-post if it be at all rotten. Stores up large supplies of grain and roots, also beech-nuts, when the mice are nesting near beech trees."

FIBER, Cuv.

F. zibethicus, L. Muskrat.

The largest of our Murida.

"Formerly was much more abundant than at present, but is still numerous. Strictly aquatic, in a measure gregarious, and at all times omnivorous. Muskrats feed largely upón Unios in the summer, and the roots of aquatic plants at other times. Occasionally suckers are caught and devoured by them, they being abcut the only fish too sluggish in movement to easily escape pursuit. They build nests of hay in trees, a short distance above the water, and during the day lie on them, sunning themselves. These nests are used by them in winter, when they sleep the greater portion of the time. They also burrow into the banks of the streams, and frequently these burrows are but several entrances to one chamber. The opening is always under water. In the chamber the young are born, and it is in these burrows they spend most of their time during the summer; but if drowned out by freshets they take refuge in the winter nests in the trees. Although so frequently seen moving about during the day, they are strictly a nocturnal animal. The fur of the animal is valued sufficiently to render them worthy the trapping, and their flesh is by no means unpalatable, especially the tails." 


\section{Family LEPORID里.}

\section{Rabbits.}

LEPUS, L.

L. americanus, Erxl. Northern Hare. White Rabbit.

Large size; hind feet longer than head; ears about equal in length to head; fur brown in summer, white in winter (at the tip of hairs). Lives in woods. Perhaps occurs in the northern counties.

L. sylvaticus, Bach. Rabbit. Gray Rabbit.

Size small; hind feet not longer than head; ears $\frac{2}{3}$ of head; color grayish, tinged with brown and black, white below. More southern than the preceding. It does not change to lighter color in winter.

"Abundant throughout the State. During the summer the majority of the rabbits remain in the woods and swamps and move about but little. The does have two litters in a year, the first dropped" in May and the second in August. The nest is variously placed, and frequently is so exposed that not only the old fall victims to hawks, but the young to prowling mammals. Very frequently pigs come across the nests, and eagerly devour the occupants. Rabbits are quite tame during the latter part of the summer, and are found frequently in gardens; but later in the season they seem to know they are more prized by mankind, and they become wilder and seek less frequented localities. They are easily trapped by baiting a 'figure-of-four' box-trap with apple, especially during the winter, when the snow is over their favorite food. Rabbits frequently do serious mischief by gnawing the bark of young fruit trees, very generally killing the trees. During heavy snows rabbits make for themselves slight. burrows and protect them overhead by overarching the grass. In this way they secure for themselves a comfortable little cave during the storm and while the snow lasts. They seem to be able to go a long time without food. Though very lively when disturbed during the day, rabbits are really nocturnal." 


\section{Order CARNivora.}

\section{Family FELID ZE. \\ Cats.}

LYNX, Raf.

L. rufus, Guld. Wild-cat.

Inner sides of legs with dark cross bands; tail with a black patch at end above, preceded by half rings.

"Very rare, and probably will be wholly extinct in a year or two. In the southern counties, among the still undisturbed swamps, there are yet, no doubt, perhaps two or three pairs still living. In Mercer, Middlesex, Essex, Hunterdon, \&c., they have been for some years extinct, and it is merely a matter of speculation as to whether or not they are found about the Blue Mountains and that portion of the State [1868].

"In 1852 a specimen came down the Delaware during a high freshet-was taken near Trenton, and although apparently dead when found, it revived. This may have come from the northern part of the State, but it is by no means certain. The females have a single litter about May, the kittens shifting for themselves in August. Wild-cats frequent heavy timber land and prey upon birds principally, and also upon rabbits and squirrels. Domestic cats not unfrequently ' run wild,' and have, when tawny-colored, been mistaken for the Lynx rufus. The smaller size and longer tail of the former ought to readily undeceive any one."

\section{Family CANID}

Dogs.

\section{VULPES, Bris.}

V. vulpes, L. (fulvus,) ' Red Fox. Cross Fox. Silver Fox. Black Fox. Chiefly red, with black feet and ears; tip of tail white; quite variable in color. 
"Formerly was very abundant throughout the State, but now is very rarely met with. Like the wolf and cougar, it has been too much persecuted to still add to the fame of our State, and were it not that its burrows rendered it less easily found, it would have long since been extinct. The last specimen seen in Mercer county was in 1850, and it is doubtful if others are now living in that or the adjoining counties. The northern and extreme southern sections of the State are the favored localities, if they exist at all. They prefer heavily-timbered hillsides to any other locality, and at night make 'telling' raids on hen-roosts."

\section{UROCYON, Bd.}

U. cinereo-argentatus, Sehr. (V. virginianus.) Gray Fox.

Fur dusky; hairs hoary at tip ; tip of tail usually dark.

"In the southern counties that have salt-marsh and sea-coast boundaries, and in those localities where the timber and brush give sufficient shelter, the gray fox is still quite abundant. They do not appear to be found in the central portion of our State, or along the Delaware River. About May the bitches litter, producing generally five young. The gray fox feeds largely on crabs and fish; it also robs the nests of the 'mud-hen,' Rallus crepitans, and not unfrequently is sufficiently quick in its movements to capture the sitting bird. They are frequently caught and kept in hopes of their becoming tame, but they never become so far domesticated as to stay at home if they are left unchained" (1868).

\section{Family MUSTELID Ė. \\ Weasels.}

\section{MUSTELA, L.}

M. pennantii, Erxl. Fisher. Black Cat.

Color variable; belly, legs, tail and hind parts chiefly black ; length more than two feet.

"Rarely met with. None exist in the central part of the State, probably none in the southern section. About the moun- 
tains in the northern counties a few are still living, but in no appreciable numbers. Frequent water-courses, feeding largely upon fish. Seldom approach farm-houses, or attack poultry."

\section{PUTORIUS, Cuv.}

P. ermineus, Cuv. (noveboracencis.) Weasel. Ermine.

Color various; tip of tail usually black; white in winter. Length, 8 to 11 inches.

"Common. Known throughout the State and about equally abundant in the several counties, but still is nowhere actually numerous. Frequent timbered lands principally, but frequently met with in the open meadows, and when so found is a useful animal, as it now lives wholly on meadow mice. Weasels litter but once in the summer, usually May, producing generally five at a birth. Were it not for its ugly habit of raiding on poultry roosts and doing so much damage, the weasel could not be complained of, but under the circumstances merits the wrath of the farmer."

P. vison, Gap. Mink.

Brownish chestnut; tail black; length of body, 15'to 20 inches.

"Common. Probably equally abundant throughout the State, and in some localities is more numerous. Frequents meadow lands and the banks of streams principally, although frequently found in high, dry timber land. Minks litter but once during the summer, generally about the middle of June.

"If birds, meadow mice and 'chipmunks' are at all abundant in any neighborhood where minks are common, then the poultry is in a great measure free from their attacks; and only in midwinter do they ever do serious damage. In condemning them for their sins, so far as poultry is concerned, it may be as well to give them credit for the good they do-as valuable they really are, in the destruction of meadow mice."

\section{LUTRA, L.}

I. canadensis, Sab. Otter.

Color, liver brown; length, $4 \frac{1}{2}$ feet. 
"Not now abundant, although still found in the central counties of the State, but in the northern and southern sections they are still quite numerous. A water-loving animal, it is generally found about the banks and on the small islands of creeks and ponds, but occasionally in swamps, where there is but little running water. A creek traversing a thickly-grown maple and birch swamp is ever a favorite locality. About the Assanpink Creek they were, twenty-five years ago, very common, and a few still are found, this creek being the principal locality for them in the central third of the State. Otters live almost wholly on fish, and are nearly as much at home in the water as their prey. During the annual spring freshets the otter is very frequently carried down the river from its haunts, and in this way otters have made their appearance about Trenton and about New Brunswick, creating for a time no little excitement until they are captured, when the 'strange visitor' of the local columns of our papers proves to be-an otter."

\section{MEPHITIS, Ouv.}

M. mephitica, Shaw. Skunk.

Usually black, with tip of tail, the dorsal stripes and neck patch white; but it may be all black or sometimes nearly white.

"Is not very abundant in any portion of the State, nor yet entirely wanting in the fauna of any county. It appears to prefer farms to uncultivated tracts, and yet is always found to live in timber land. Any small strip of heavy timber, within half a mile of a farm-house, very generally harbors at least one skunk. Occasionally they take up their abode in winter in a haymow, and a ruining of the hay is apt to be a consequence. They prey upon poultry occasionally, but are not very destructive in this respect. The skunk is nocturnal, or in a measure so, in its habits, prowling about during the dusk of the evening, and into the night when moonlight. In the northern counties of the State they do not appear to be as frequently met with as in the central and southern sections. Judging from old records, they were formerly very abundant, and looked upon as destructive." 


\section{Family URSID Z2.}

\section{Bears.}

\section{PROCYON, Stor.}

P. lotor, L. Raccoon.

Slender, plantigrade, carnivorous; with well-developed tail, with black rings; snout elongated; color grayish white; hairs black at tip.

"Quite frequently met with in every cuunty of the State, and yet is nowhere so abundant as to be looked upon as an animal of every-day occurrence. In the northern counties they are probably less numerous than in the southern, although more common than about the central third of the State. In Mercer county they are but little seen, and when found are generally met with about the Assanpink, which traverses in part swampy, overgrown land, such as 'coons' prefer. 'Coons,' when pursued, readily take to trees, and, indeed, are seldom met with at any great distance from heavy timber. The young are brought forth in May, from four to seven being in a litter. During the spring the raccoon is a valuable beast, as it at this time of year eagerly searches out and devours quantities of grubs, and by this destruction of the larvæ of obnoxious insects largely compensates for the corn eaten by them in August. When the water-courses are strongly frozen up, and especially if there has much snow fallen, raccoons will burrow under haystacks, and less frequently under barns, living at such times in a great degree upon mice, and occasionally attacking poultry. It is doubtful if at any time they are so destructive as to warrant the persecution they seem doomed to suffer."

\section{URSUS, L.}

U. americanus, Pal. Black Bear. Brown Bear. Cinnamon Bear.

Color variable.

"Fast disappearing from the State. Now never met with in the central counties; in inappreciable numbers in the northern mountainous districts, and not more than half a dozen are annually killed in the southern section of the State. The bear has been the last of the three large carnivorous animals of the 
State (panther, wolf and bear) to disappear before the settling and clearing off of the land. Of these three the bear is the least carnivorous and less roaming, thus giving it more of a chance while any thick swamps remained" (1868).

\section{Order UNGUlata.}

(HERBIVORA.)

Hoofed Mammals.

\section{Sub-Order RUMINANTIA.}

\section{Family CERVIDE.}

Deer.

\section{OARIAOUS, Gray. \\ (Cervus, L.)}

O. virginianus, Bod. Red Deer. Virginia Deer.

Color chestnut red, grayish in winter.

"Found now only in a circumscribed locality in the southern portion of the State. Although frequently protected by law, they have never become very numerous, and the encroachments. of agricultural interests upon the now wild lands will soon cause the deer entirely to pass away. Formerly they were very abundant throughout the whole State, and a century ago the central counties were, no doubt, the favorite haunts of this animal." 


\section{Order Cetacea-CARnivora.}

\section{Sub-Order MYSTICETE.}

\section{Family, BAL \\ Whales.}

\section{BAL 开NA，L。}

(Eubalæna, Cope.)

B. mysticetes (eisarctica). Right Whale. Whalebone Whale. Black Whale, \&c.

Head very large; no teeth; 600 baleen plates in upper jaw ; no dorsal fin; 2 spiracles; eye above angle of mouth; length, 40 to 60 feet.

"Individuals of several species are occasionally cast ashore eastward, and some are known to enter New York harbor. They were formerly abundant about the mouth of the Delaware."-Cope, Proc. Acad. Nat. Sc. Phil., 1866. The finback whale (Dubertus or Gubartas) Sibaldius tectirostris, Cope, is abundant off Massachusetts. They swim so as to expose a part of the back. The sperm whale (Physeter maerocephalus, Lac.) was once abundant on our coast. De Kay mentions two species of Rorquals, Rorqualus rostratus and $R$. borealis, as having been captured in New York Bay, 1822, and in the Delaware, 1804, respectively. 


\title{
Sub-Order Odontocete.
}

\section{Family DELPHINID}

\author{
Porpoises.
}

TURSIOPE, Gerv.

T. tursio, Fabr. (Delphinus, Phocæna, metis, \&c.) Bottle-nosed Dolphin. Sea Hog, \&c.

Beak moderate, tapering, marked off from forehead; dorsal and pectoral fins falcate; color greenish gray, white below, sometimes spotted; teeth, 22 in each half jaw; length, 9 feet. Not common on our coast.

\section{DELPEINUS, L.}

D. delphis, L. Sea Porpoise. "Dolphin."

Body slender; head slopes gradually into long beak; pectorals narrow; color black above, lighter below, with gray lateral bands; teeth, 46 to 51 in each half jaw; length, 7 feet. This species frequents the high seas; it should not be confounded with a true fish called the "Dolphin."

\section{PRODELPEINUS, Gerv.}

(Delphinus.)

P. plagiodon, Cope. Spotted Dolphin.

Beak stout, shorter than preceding; color dark purplish above, with gray spots, and whitish below, with dark-gray oblong spots; teeth, 37; length, 7 feet. Southern-ranges northward to Cape Hatteras. Inserted here for sake of comparison.

P. frcenatus, F. Cuv. (D. clymene, Gr.) True Dolphin.

Smaller than preceding; color of belly sharply separated from dark upper parts; spotted like former but smaller and more numerous above; teeth, 38 ; length, 6 feet. Rare. A specimen from our coast is in the Philadelphia Academy. 


\section{LAGENOREYNCHUS, Gr.}

L. acutus, Gr. (perspicillatus.) Skunk Porpoise. Bay Porpoise.

Beak short, plowshare-like; body largest forward; flukes large; color black above, gray laterally, yellow patch on tail and white patch further forward, also irregular dark bands; teeth, 35 to 37 ; length, 8 feet. Abundant about Cape Cod.

\section{PHOC纽NA, Cuv.}

P. communis, Less. (D. brachycion.) Harbor Porpoise. Herring Hog. Common Porpoise.

Jaws equal, size small ; color blackish above, fading to whitish belly, sometimes with yellowish tinge; margin of lower jaw black; teeth, 26 ; length, 5 feet.

"This is the abundant species so common not only along the coast, but in the mouths of the rivers. They have been seen in the Delaware as high up as Trenton, and are common in the Hudson north of the New Jersey State line.

"They frequently are seen sailing along with a slow and measured motion, just appearing at the surface by elevating the crown of the head, and then diving short, so as to make their bodies describe the are of a small circle, exposing themselves to. view only from the crown of the head to a short distance behind the dorsal fin. Occasionally a troop of them may be seen scudding along, rising in this manner in quick succession, as if anxious each to get in advance of the other, while again a single individual may be observed successively rising and falling in the same way, as if engaged in the act of catching a prey."

Have been known to kill schools of drumfish.

\section{GRAMPUS, Gr.}

G. griseus, Cuv. (D. globiocephalus.) Grampus. Cowfish.

Head globular; lips beak-like; mouth oblique; dorsal fin high; pectorals long and falcate; flukes narrow; above dark gray and variegated, laterally, with yellowish and gray; whitish belly, with streaks; no teeth in upper jaw ; length, 10 feet.

True, in his "Review of the Delphinidæ," Bul. No. 36, U. S. 
Nat. Mus., to whom I am indebted for this list of identifications, includes Atlantic City, New Jersey, in the habitat of this species. It is rare south of Cape Cod.

\section{GLOBIOEPHALUS, Gr.}

G. melas, Traill. (Phocana, Delphinus, intermedius.) Blackfish. Black Whale. Social Whale. Pilot Fish.

Forehead protuberant; body deep at dorsal fin; uniformly black, except a white arrow-shaped line on belly; teeth, 10; length, 15 feet. Breed in summer about Cape Cod. Rare on New Jersey coast.

G. brachypterus, Cope.

Like preceding, but with shorter pectorals ; dorsal fin far forward and color all black; teeth, 8. Rare.

\section{ORCA, Gr.}

O. gladiator, Lac. Gladiator Dolphin. Killer, \&c.

Dorsal fin "very high in male; head broad and flat; no beak; pectorals short; color black, with a trident-shaped white mark on belly. Pelagic and of great size, and a terror to all other Cetaceans. Both jaws studded with conical teeth. Rare inshore.

\section{Order Marsupialia.}

\section{Family DIDELPHID止.}

\section{DIDELPHYS, L.}

D. virginiana, Shaw. Opossum.

Tail long, nearly naked, scaly, with few hairs; toes prehensile; dirty white color ; legs dark. Length, 35 inches ; tail, 14 inches.

"Common, and about equally abundant in the several counties of the State. It frequents wooded tracts principally, and spends the greater portion of its time in trees, or in burrows at the roots of large trees. They are nocturnal in their habits, and it is 
seldom they are met with during the day, as they, when sleeping in trees, lie so closely to the branch on which they rest as tc escape observation. The opossum moves with great facility among trees, and not unfrequently captures birds while sitting on their nests. On birds and their eggs and young they rely mainly for food. The mother carries her young with her in a pouch peculiar to the order, and when the young fill this pouch to its utmost capacity, they still move freely about trees. Occasionally they hang from a limb, head downwards, holding on by a turn and a half of their tails. After the persimmons have been touched with the frost and lost. their excessive astringency: the opossum feeds upon thẹm very greedily, and a 'possum hunt' by moonlight is most successful when they are sought for among persimmon trees. Although it occasionally happens that poultry is attacked by these animals, such is so seldom the case that it is hardly just to them to say they are an offensive animal."

\section{Cuass aVEs. \\ Birds.* \\ Section SCANSORES.}

Climbing Birds.

Order PICl.

Family PICID az.

Woodpeckers.

DRYOBATES, Boie.

(Picus, L.)

D. villosue, L. Big Sap-sucker. Hairy Woodpecker.

Spotted and lengthwise streaked, but not banded; back black: with a long white stripe; outer tail feathers wholly white Length, 9 inches; tail, $3 \frac{1}{2}$ inches. Male with a scarlet nucha] band.

* Ridgway's Manual of North American Birds has been followed in the nomencla. ture of the families and smaller groups. 
"Resident; everywhere abundant. Frequents apple orchards perhaps more than other places, and is in a measure destructive to the younger trees, and to all growing timber, by the innumerable perforations it makes in the bark, sometimes completely girdling the tree. Feeds exclusively on insects and their larvæ. Builds in decayed trees, in May."

D. pubescens, L. Downy Woodpecker. Little Sap-sucker.

Outer tail feathers black and white, barred. Length, $6 \frac{1}{2}$ inches; tail, $2 \frac{3}{4}$ inches. Otherwise like preceding.

"Equally abundant, and with the same habits as the preceding. It has been suggested that this and the preceding species only perforated the bark of young trees when they have discovered larvæ of insects beneath; but such is not the case, as they perforate to see if larvæ are beneath, not knowing beforehand. The insects themselves are more injurious than the birds, many times over; and were only 'insect-ridden' trees visited by the woodpeckers, it would be our duty to defend them. Still, it is doubtful if the injury they inflict overbalances the good."

D. borealis, Vieill: Red-cockaded Woodpecker.

Black and white, spotted and crosswise banded, but not streaked; a red line on each side of the head in males. Length, $8 \frac{1}{2}$ inches; tail, $3 \frac{1}{2}$ inches. A southern form inhabiting swamps, and ranging north as far as Pennsylvania. A few possibly may visit our southern swamps.

\section{SPEYRAPICUS, Bd.}

Sap-Sucking Woodpeckers.

S. varius, L. Yellow-bellied Woodpecker, or Sap-Sucker.

Black and white above; black on breast, chiefly yellowish below; white wing patch; crown red in the adult; chin scarlet in males. Length, $8 \frac{1}{4}$ inches ; tail, $3 \frac{1}{3}$ inches. The young are of a mottled brownish tint. The adult female has the chin and throat white.

"More abundant during spring and autumn. Seldom seen during the summer, although a few breed in the northern hilly sections of the State. Strazglers occasionally seen during the 
winter about barns, in which they, not improbably, take refuge during the severer weather. The 'flicker' has also been known to do this."

\section{CEOPHLEUS, Cab.}

(Hylotomus, Bd.)

C. pileatus, L. Black Woodcock. Pileated Woodpecker. Black Logcock.

Black, with white streak down neck; males with crest and cheek patch scarlet; and general color may vary from black to slaty. Females with the head without scarlet, but color brownish gray. Length, 18 inches; tail, 7 inches.

"Stragglers occasionally seen; occasionally in the dark swamps of Cape May county; but more frequently in the mountainous portion of the State. This is one of a number of birds formerly very abundant, but now nearly extinct, being driven off by the destruction of the heavy timber, in which they lived."

\section{MELANERPES, Swains.}

M. erythrocephalus, L. Red-headed Woodpecker.

Head, neck and chest a rich crimson, with a black collar separating the white of breast from the crimson above; the back glossy blue black; lower back, rump, \&c., pure white; the inner secondaries spotted with black in the female. In young, the upper and forward parts brownish gray; the back dull grayish, barred with dusky gray; the secondaries crossed by black bands. Length, $9 \frac{1}{2}$ inches; tail, $3 \frac{1}{2}$ inches.

"Formerly a very abundant species, but now quite scarce. Have found two or three pairs breeding about Stony Brook, near Princeton, Mercer county. Partially migratory, probably twofifths of their numbers remaining in the State during winter. Occarionally hollows out a nest in sound timber-not otherwise objectionable. More abundant in the northern than southern and central portions of the State. Like the 'yellow-bellied woodpecker,' the ' red-head' has been found in hay-mows during severe winter weather, and noticed gathering up hibernating insects from beneath the weather-boards. Is more beneficial than the smaller species." - [C. C. A.] 
M. carolinus, L. (Centurus, Swains.) Red-bellied Woodpecker.

Grayish, much barred above with black and white; crown and nape crimson in male; crown ashy in female; belly reddish. Length, $9 \frac{3}{4}$ inches; tail, $3 \frac{1}{2}$ inches.

"Not common; migratory; arrives in April, and generally passes on. Have seen but one nest of the species; which nest was in Ocean county, and when discovered contained young birds; the date of finding it was May 29th, 1861. In September they are generally more common, and often remain for six weeks, about old apple orchards principally. Have seen none in winter."-[C. C. A.]

\section{COLAPTES, Swains.}

C. auratus, L. Flicker. Golden-winged Woodpecker. Yellow Hammer. High-holer. Yarup.

Head ashy, with red nuchal crescent; back olivaceous, barred with black; rump white; below, pinkish shading into yellowish; a black crescent and many round black spots on breast; shafts and under-surface of quills golden yellow; a black "mustache" in male. Length, $12 \frac{1}{2}$ inches ; tail, $4 \frac{1}{2}$ inches.

"Resident and migratory. Very abundant. Flickers build almost always in decayed wood, and have this in their favor. Are very ravenous, and destroy more insects than all the other woodpeckers together. In August they become partially gregarious, and in a measure forsaking timber, frequent meadows, and feed largely upon crickets and grasshoppers. After the appearance of several severe frosts, they seek the timber again, and are especially abundant about gum-trees, the berries of which , they are very fond of. They are the most noisy of their tribe among us, and their guttural note has given rise to several names, as 'Yucker,' 'Wake-up,' 'Flicker,' \&c. They are also known as 'Yellow Hammers,' 'High-holes,' 'Claips,' \&c. The name 'High-hole' probably arises from their generally building at as great an elevation as, the tree selected will admit. As has been stated, they frequent out-buildings in midwinter, especially barns, roosting in hay-mows." 


\section{Order Cuculi.}

(COCCYGES.)

\section{Family CUCULID E.}

\section{Cuckoos.}

\section{OOOCYZUS, Vieill.}

O. americanus, L. Yellow-billed Cuckoo.

Bill yellow below; wings with much cinnamon red; middle tail feathers like back, olive gray; outer ones black, with broad white tips. Length, 12 inches; tail, 6 inches. Inner and outer toes turn back.

"Makes its appearance in May, and remains till October. Feeds exclusively upon insects, generally caterpillars. Builds a loose nest of sticks, raising one brood only."

C. erythrophthalmus, Wils. Black-billed Cuckoo.

Bill chiefly black; little or no red on wings; tail feathers all brownish, obscurely white at tips. Length, $11 \frac{1}{2}$ inches; tail, $6 \frac{1}{4}$ inches.

"In its habits this cuckoo is similar to the above, but it is not as abundant a species, and is apparently more shy and frequents less populated localities."

\section{Family ALCEDINID}

\section{Kingfishers.}

OERYLE, Boie.

C. alcyon, L. Belted Kingfisher.

Ashy blue above; a band across breast, bluish in male, chestnut in female; white below; tail transversely spotted with white. Length, 13 inches ; tail, $3 \frac{1}{2}$ inches ; bill, 2 inches. 
"Although a migratory species, a few not unfrequently remain throughout the winter, and seem to find a sufficiency of food when the streams are frozen. It appears in numbers as early as February, if the weather is moderate, and seldom wanders far from fishing-grounds. Is an inoffensive species, except in the destruction of young pike."

\section{Order Cypseli.}

(MACROCHIRES.)

\section{Family CAPRIMULGIDA.}

\section{Goatsuckers.}

\section{ANTROSTOMUS, Gould.}

A. vociferus, Wils. Whip-poor-will. Night Jar.

Grayish, much variegated; "the mouth is margined by enormous stiff bristles more than an inch long; the wings are short, not reaching the end of the tail, which is very broad and rounded. There are bars of rufous spots on the wing quills, but no white whatever. The tail is white beneath for its terminal half" in males, tawny in females. Length, 10 inches; tail, 5 inches. Do not confound this with the next species.

"Migratory and in the extreme sections of the State, only, abundant. Their nests are shallow scooped holes in the dead leaves, two eggs being deposited. The food is exclusively insects. Habits nocturnal. Strictly inoffensive."

\section{CHORDEILES, Swains.}

(Popetue-Abbott's Catalogue.)

C. virginianus, Gmel. Night Hawk. Bull Bat.

Blackish, variegated; a V-shaped blotch on throat-white in male, tawny in female; "the bristles of the bill are scarcely appreciable; the wings are sharp-pointed, longer than the tail, uniformly brown, with a broad spot of white across the middle of the long quills, and without any rufous spots. The tail is rather 


\section{4}

narrow, forked" and with a square blotch or a bar of white near the end. Length, $9 \frac{1}{2}$ inches; tail, 5 inches.

"Migratory. Moderately abundant throughout the State. Sociable in their habits, when on the wing, flying frequently low down through the streets of our towns. Semi-nocturnal. Their food consists exclusively of insects. Strictly inoffensive."

\section{Family CYPSELIDZz.}

(Micropodidæ.)

Swifts.

\section{OH无TURA, Steph.}

C. pelagica, L. Chimney Swallow, or Swift.

Sooty brown; throat paler. Length, 5 inches; tail, 2 inches. "Abundant. Arrive early in April, remaining until late in October. Their nests, as is well known, are generally in chimneys. Not unfrequently they are in hollow trees, even near a town. They raise three broods generally. Their food is exclusively of insects. Strictly inoffensive."

\section{Family TROCHILID A.}

\section{Humming Birds. \\ TROCHILUS, L.}

T. colubris, L. Ruby-throated Humming Bird.

Bill long; tongue capable of great protrusion; wings long and pointed, the secondaries short, only six in number; rectrices ten; feet very small, with sharp claws; male, metallic green above, chin velvet black; a ruby-red gorget; tail deeply forked. Female without red; tail double-rounded and variegated (green, white and black). Young male resembles adult female; young female like young male, but no streaks on throat, and tail more rounded. Length, $3 \frac{1}{4}$ inches; tail, $1 \frac{1}{4}$ inches; bill, $\frac{2}{8}$ inch. 
"Arrive in May, and by twos or threes are seen hovering about flowers, or darting now and then among swarms of minute insects then beginning to fill the atmosphere. Humming birds are more sociable than they are supposed to be; and although their nests are generally in unfrequented positions, yet it is by no means always so, and the author has found them building in trees whose branches were in direct contact with the house. It may be that the flowers they most love are the cultivated ones, but this is by no means certain. The nest is built of fine grass, is lined with hair, and covered upon its exterior with lichen, rendering it very difficult to detect, as generally a scrubby oak is chosen, which has its branches frequently well covered with the same growth. The eggs are two in number. During incubation the males are very bold, and fearlessly attack any intruder. The author has had them to fly directly in his face, while inspecting their nests. They have generally disappeared by September 15th, but the writer has seen them after severe frostsone as late as October 19th. During some summers are much more abundant than others."-[C. C. A.]

\section{Section INSESSORES.}

Perching Birds.

\section{Order passeres.}

\section{Family TYRANNIDE.}

Tyrant Flyoatchers.

\section{MILVULUS, Swains.}

M. tyrannus, L. Fork-tailed Flycatcher.

Top of head deep black, with a concealed patch of yellow in middle of crown; back light bluish gray; lower parts white. Length, 15 inches; tail, $9 \frac{1}{2}$ inches. Female somewhat smaller; the tail much shorter and less forked. No yellow crown spot or 
- forked tail in the young, and colors duller. Tropical birds, accidentally found in New Jersey.

M. forficatus, Gmel. Scissor-tailed Flycatcher.

Tail feathers chiefly white; top of head ash gray; back tinged with red; scarlet crown patch (concealed); white parts below washed with salmon pink; bluish gray anteriorly. Length, 14 inches; tail, 9 inches. Female smaller and duller. Young, no crown spot. Accidental in New Jersey.

\section{TYRANNUS, Cuv.}

T. tyrannus, L. (carolinensis.) Kingbird. Bee Martin.

Blackish ash, white below ; tail black, white tipped. Length, $8 \frac{1}{2}$ inches ; tail, $3 \frac{1}{2}$ inches.

"Migratory. Very abundant from May till November. Were it not that they destroyed very many honey-bees would be very useful. But a single brood is raised in a season. The nest is generally in an apple tree."-[C. C. A.] "Destroys a thousand noxious insects for every bee it eats."-Coues.

'T. dominincensis, Gmel. Gray Kingbird.

Color leaden gray above; concealed orange crown patch. Accidental in Massachusetts (from the South), possibly also in New Jersey.

T. verticalis, Say. Arkansas Kingbird, or Flycatcher.

Belly yellow; tail deep black, white edged; ash gray above; concealed crown spot of yellow. Length, 9 inches; tail, $3 \frac{3}{4}$ inches. Western-straying to New Jersey.

MYIARCHUS, Oab.

M. crinitus, L. Great-crested Flycatcher.

Throat and chest deep ash gray; belly bright sulphur yellow; back, \&c., decidedly olive; bright chestnut on wings and tail. "Scarcely crested." Length, 9 inches; tail, 4 inches. Uses cast-off snake skins in the construction of its nest.

"Migratory. Not numerous. This species is a solitary bird, only single specimens being found, except during incubation. They feed upon insects generally, and are not sufficiently numerous to affect the bee colonies." 


\section{SAYORNIS, Bonap.}

S. phœbe, L. (fuscus.) Pee-wee. Phœbe. Pee-wit.

Olive brown; head and tail darker; yellowish or white below. Length, $6 \frac{3}{4}$ inches; tail, $3 \frac{1}{4}$ inches.

"Late in February or early in March, according to the weather, this little bird makes its appearance. It builds a nest generally about bridges or the eaves of a house, if sufficiently projecting, raising two broods. Strictly inoffensive."

\section{CONTOPUS, Cab.}

C. virens, L. Wood Pee-wee.

Rictal bristles half length of bill; olive brown above; pale or yellowish below; whitish or rusty bands on wings. Length, $6 \frac{1}{4}$ inches; tail, 3 inches.

"Very similar in general appearance to the above, but differing in its habits. It builds a nest on the upper surface of a branch of a tree and covers it with lichen externally. The eggs are spotted with red, and not pure white as with the $S$. fuscus. Frequents orchards and woody districts, and is as solitary as the above is sociable. Feeds exclusively on insects, and is a valuable bird."

o. borealis, Swains. Olive-sided Flycatcher.

Rictal bristles short, $\frac{1}{4}$ length of bill ; tuft of cottony feathers on each side of rump, conspicuous; a white line along middle of

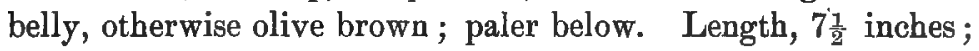
tail, 3 inches. A northern form ranging as far south as New York, ànd should be looked for in our northern counties.

\section{gMPIDONAX, Cab.}

F. pusillus-traillii, Aud. Traill's Flycatcher.

Dull olive brown; bill pale below; lower parts tinged with yellow. Length, $5 \frac{3}{4}$ inches; tail, $2 \frac{1}{2}$ inches.

"Arrives in May, remaining till October. This flycatcher is restless and stays generally among the tops of tall trees. A single brood is raised in a season, the young leaving the nest in July. Strictly inoffensive." 
E. minimus, Bd. Least Flycatcher.

Olive gray; bill blackish below, length less than $\frac{1}{2}$ inch; wing-bands usually whiter than in preceding; middle toe half as long as tarsus (shorter than in preceding); otherwise difficult to. distinguish from preceding.

"Numerous from May till October. Prefers tall trees, but is more sociable than the foregoing. Is frequently seen in towns, especially about old mulberry trees.' Nidificate in May, raising one brood. Strictly inoffensive."

E. acadicus, Gmel. Blue-gray Flycatcher. Small Green-crested Flycatcher. Acadian Flycatcher.

Clear olive green, with buffy wing bands ; whitish or yellowish below ; yellow ring about eyes; bill pale below. Length, 6 inches ; tail, $2 \frac{3}{4}$ inches.

"Abundant everywhere from May till late in October. Like the foregoing, prefers tall trees, and is a sociable little bird, although abundant in secluded timber lands. Nidificate in May, and occasionally again in July."

E. flaviventrie, Bd. Yellow-bellied Flycatcher.

Clear olive green; yellow below; bright yellow on belly; bill yellow below. Length, $5 \frac{1}{4}$ inches; tail, $2 \frac{1}{2}$ inches.

"Although numerous in the northern portions of the State, this bird generally is not an abundant species. Prefers unfrequented localities and is seldom seen in towns, as are the flycatchers generally."

\section{Family ALAUDID五.}

Larks.

\section{OTOCORIS, Bonap.}

O. alpestris, L. (Eremophila cornuta.) Shore Lark. Horned Lark.

Tarsus sentellate in front and behind; nostrils concealed by tuft of feathers; a slight tuft of feathers over each ear. Nest imbedded in ground under shelter of grass, \&c. Pinkish brown, thickly streaked; a black crescent on breast and strip under eye; 
chin, throat and line over eye more or less yellow; less black in females; white below. Winter plumage with markings more obscure. Length, $7 \frac{1}{4}$ inches; tail, 3 inches.

"Resident. Abundant. This lark is always found in flocks, except during the breeding season. They are equally numerous throughout the State. They feed upon insects principally, and in October become very fat. During a visit to Barnegat in November, 1862, the author daily saw very many on the beach, moving about like sand-pipers."-[C. C. A.]

\section{Family CORVIDAz.}

\section{Crows.}

CYANOCITTA, Strick. (Cyanura.)

C. cristata, L. Blue Jay.

Blue; collar and frontlet black; grayish below; wings and tail clear blue, barred; outer tail feathers and secondaries tipped with white. Length, 12 inches; tail, $5 \frac{3}{4}$ inches. Conspicuously crested.

"Resident. Common. The jay appears to be equally abundant throughout the State. During the summer they are shy and live entirely in secluded woods, where they breed, raising one brood. During the winter they are more sociable and occasionally bold. They feed upon birds' eggs during the spring, and at other seasons are omnivorous. They occasionally peck at corn stored in cribs."

\section{CORVUS, L.}

C. corax principalis, Ridg. (carnivorus, Bartr.) Northern Raven.

Feathers of throat stiffened, elongated and narrow ; tail shorter than the long-pointed wings. Length, 25 inches ; tail, 10 inches. Nests among rocks.

"Though frequently seen along the sea-coast, the raven is a rare bird inland, in New Jersey. A few are occasionally above 
Trenton, about the Delaware, but no nests have been found. Their larger size, and loose, lace-like feathers of the neck; distinguish them from "crows." "

C.'americanus, Aud. (frugivorus, Bartr.) American Crow.

Feathers of throat short, broad, with their webs blended; gloss of plumage purplish violet; head and neck hardly lustrous. Length, 20 inches ; tail, $7 \frac{1}{2}$ inches.

"Resident. Abundant. Crows are so numerous that from this fact alone they are supposed to be thoroughly understood by every one; in reality they are misunderstood and misjudged by nearly every one. Crows build in March, in tall trees, and raise generally two broods, the second leaving the nest in June. During the spring they are troublesome, on account of a habit of removing the. lately-planted corn, but if any one will take the trouble to kill a crow after feeding on the corn, and examine the contents of the crop, he will find a large number of worms therein, and the corn that they have eaten, worm-eaten. Corn washed with coal-tar before being planted is always undisturbed, but the crows frequent the fields as numerously as ever, now carrying off worms only. Were this generally done, the crows now'so persistently shot at would be soon appreciated and protected. Crows destroy annually many bushels of grain in the State, and at the same time destroy many millions of noxious worms. If these were left undisturbed, a thousand-fold more grain would be destroyed. During the summer, autumn and winter, crows are emphatically omnivorous, feeding upon whatever may come in their way. In very shallow water they gather mussels, and letting them drop from a height, they break the shells and devour the animal."

C. ossifragus, Wils. (maritimus, Bartr.) Fish Crow.

Gloss of plumage green and violet, evident on head and neck. Length, 16 inches; tail, 7 inches.

"Not abundant on the coast and very seldom seen inland. They are smaller than the common crow and have a rather more musical 'caw.' They feed upon fish, crabs and the debris of the beach, and are very inoffensive. During some seasons they are more numerous than others." 


\section{Family ICTERID ze. \\ Orioles.}

\section{DOLICEONYX, Swains.}

D. oryzivorus, L. Reedbird. Ricebird. Bobolink.

Male in spring black; neck buffy; shoulders and rump ashy white; back streaky; in autumn yellowish brown, streaked above. Female like fall male, dull yellow, resembling sparrows, but with acute tail feathers. Length, $7 \frac{1}{2}$ inches; tail, 3 inches. In autumn migrate southward to fatten in the rice swamps.

"Arrives early in May, and soon after nidification commences. But a single brood is reared. In August, after moulting, the males are feathered similarly to the females, and they now become gregarious. In flocks frequently of a thousand individuals, they frequent the reeds, and are then called 'reedbirds,' having been known as 'bobolinks' during the early summer. In September they are very fat, and are eagerly sought for as a delicate article of food. They remain on the reeds until the appearance of several sharp frosts, when they go south, migrating at night. The male birds during the spring have a varied, beautiful song, but in August it has changed, as has also the female's chatters, to a single note."

\section{MOLOTHRUS, Swains.}

M. ater, Bodd. (pecoris.) Cow Bird.

Male iridescent black; head and neck glossy brown; female smaller; dusky gray brown, with short blackish bill. Length (male), 8 inches; tail, 3 inches.

"Arrives early in April, and is found generally in meadows in loose flocks until May, when the females scatter through the country and deposit two or three eggs, one each in a nest of another bird. The warblers and sparrows are the birds generally so favored. Later. in the summer, after the young can fly, they become partially gregarious, and usually are found with the 'red-wings.' They are known throughout the State as 'sheep blackbirds.' Feed on insects and are strictly inoffensive." 


\section{XANTHOOEPHALUS, Swains.}

X. xanthocephalus, Bonap. Yellow-headed Blackbird.

Male black, with white wing patch; head and neck rich yellow; female smaller, browner and less yellow. Length, 10 inches; tail, $4 \frac{1}{2}$ inches. A western form straying occasionally to the Atlantic border from Massachusetts to Florida.

\section{AGELAIUS, Vieill.}

A. phœniceus, L. Red-winged Blackbird, or Starling. Swamp Blackbird.

Male glossy (not iridescent) black; lesser wing coverts scarlet, with buffy paler edgings; female dusky; plumage everywhere streaked; rusty tinge on throat. Length, 9 inches; tail 4 inches.

"Equally abundant throughout the central and southern portions of the State. Numerous about the northern, hilly sections. 'Red-wings' are migratory and do not, as is the case with 'grackles,' remain in scattered flocks during the winter, probably amounting to one-fourth of their number. Appearing in scattered twos and threes, often as early as March 1st, they frequent now only the meadows and vicinity of creeks, the males singing continually, and when courtship has ended, suitable localities for nidification are sought, and two broods are raised, the eggs of the second being deposited about a week after the previous brood has left the nest. The second brood is usually fully fledged by the middle of July. During the breeding season, the 'red-wings' live largely upon worms, grubs and aquatic insects, and after numerous examinations, it has been found that they do not feed their young upon grain, although at this time they are generally very attentive to corn-fields, and certainly do exhume a considerable quantity, but it is seldom the case that corn has to be replanted solely in consequence of the previous planting having been taken up by ' red-wings.' In September, these birds collect in flocks, frequently numbering à thousand individuals, and frequent now only the low marshy lands. In company with the ' reedbirds,' they are mostly found about the reeds, and feed almost wholly on the seeds of this plant, and insects. By No- 
vember 1st they have all gone south, frequenting rice plantations generally.

"Red-winged blackbirds are always looked upon as injurious to agriculture, and treated accordingly. The Patent Office Report for 1856-Agriculture-advocates their destruction as an injurious bird, but we doubt very much if the author of the article above referred to ever suffered from their attacks any more than he or any other has from the predatory visits of that largely useful and wholly inoffensive bird, the rose-breasted grosbeak, which also is considered as deserving of persecution. 'Red-wings' do take corn up when it is planted, and do feed upon it when in the milky state, but their diet of grubs, worms and noxious insects, throughout the greater part of the year, far more than compensates for any injury they do the corn-crop. The 'red-wing' following the plow in early spring, and careless of the plowman, devours the grubs the plow exposes, preserves more grain by each worm destroyed than the bird will itself eat, in August, an hundred times over. The 'red-wings' are about as frequently innocent as guilty, when accused of ' taking up' the corn, the grubs being the real offenders, and their destructiveness, when the corn is in a milky state, is largely exaggerated, and if they are killed at this time the contents of their crop will show that four-fifths of their food has been the insects always to be found on corn-stalks, and the angle-worms that the loose ground about the corn invariably contains."-[C. C. A.]

\section{STURNELLA, Vieill.}

s. magna, L. Meadow Lark.

Brownish and much streaked above; chiefly yellow below; a black crescent on breast; bill long; tail short, with acute feathers; crown feathers bristle tipped. Length, 10 inches; tail, $3 \frac{1}{2}$ inches.

"Resident. In the spring they are in a measure gregarious, and frequent the meadows. About the middle of May they pair and build a nest of grass, on the ground, raising two broods, the young of the latter brood not flying before August 15th. About this time they become again partially gregarious, and in a measure forsake the meadows for the uplands, generally frequenting the stubble-fields. In October they are frequently 
very fat and afford excellent eating, but being, during the summer, a strictly insectivorous species, it is doubtful if it were proper to kill them."

ICTERUS, Briss.

I. spurius, L. Orchard Oriole.

Male black; rump, bend of wing and lower parts deep. chestnut; bill acute, bluish; female yellowish olive; smaller than male; young yellow, with chestnut traces. Length, 7 inches; tail, 3 inches.

"Arrives in May and remains during the summer. Has no preference of locality, except in building its nest-as it chooses a tall tree and places the nest usually very near the top. Feeds. largely upon insects. Seldom carries off any fruit. Returns. south in October. Strictly inoffensive."

I. galbula, L. (baltimore.) Baltimore Oriole. Golden Robin. Fire Bird.

Male black; tips of greater wing coverts white; lesser and middle wing coverts, base and tip of tail, rich cadmium orange, orange red or lemon yellow; female variable, duller; olivaceous and yellow, spotted with black; white bands to most of wing feathers. Length, 7 inches ; tail, 3 inches.

"Arrives in May, and remains during the summer. Is a more sociable bird than the preceding, and generally more abundant. Builds in willow and elm trees principally, raising but one brood. Refits the old nest, year after year, if undisturbed. Feeds on insects, and is very fond of cherries, though it generally takes the wormy in preference to the sound ones. Has generally gone by September 15th. Feeding so largely upon insects, is a valuable bird."

\section{SOOLECOPHAGUS, Swains.}

S. carolinus, Müll. (ferrugineus-Abbott's Catalogue.) Rusty Blackbird.

Wings longer than tail; plumage black, often obscured by brownish or rusty; no red or yellow; bill slender; male glossy black and rusty in autumn; female dusky and lusterless. Length, $9 \frac{1}{2}$ inches; tail, 4 inches.

"Arrives in New Jersey about the 1st of April, occasionally sooner, and in small flocks is dispersed generally throughout the State. Is nowhere abundant, and among the people generally, 
passes as a 'crow blackbird,' as it indeed seems to be, when seen flying, or is in company with the Quiscali. There is no marked difference in the habits of this bird as compared with allied species, and in so far as usefulness and destructiveness are concerned, is upon a par with them. It is probable that this species is found in New Jersey only occasionally, as search for it has proved unsuccessful in about two summers of every five.[C. C. A.]

"Low meadow lands and the immediate neighborhood of our rivers and larger creeks, are their favorite haunts, and in trees, in such situations, they build their nests. Small fresh-water shells and spiders are eagerly devoured by them, and on "such food they preferably subsist, when obtainable; at least, such is the case so far as their habits have been noticed by the author.

"This bird is easily distinguished from the grackle by the marked difference in the bill, and the general ferruginous tint of the plumage. They seldom remain after the middle of September, appearing to be remarkably sensitive to atmospheric changes."

\section{QUISCALUS, Vieill.}

Q. quiscula, L. (versicolor.) Purple Grackle. Crow Blackbird.

Iridescent black; wings scarcely longer than tail; luster on head purplish, on body bronzy. Length, 13 inches; tail, $5 \frac{1}{3}$ inches.

"Purple grackles, or crow blackbirds, as they are more generally known, are very abundant throughout most portions of the State, from February 15 th until November; and not unfrequently single specimens or two or three together are met with during the winter. In proportion as meadow lands abound, especially when skirted by well-grown timber, they appear to be numerous, and during the whole of their stay they are gregarious, though never seen in such immense flocks as in the case of the 'red-wing.'

"About April 25th nidification commences, and generally a large number of nests are in close proximity; occasionally three upon the same tree, if the tree be large or bushy, as a cedar or hemlock. Very frequently an orchard will be the favored locality with the grackles, and the author has seen in an orchard of seventy trees one hundred and thirty-one nests, being nearly two 
nests to a tree; the distribution was not very even, however, as one tree had five nests on, and nine trees none. Two broods are generally raised, the second leaving the nests about July 15th.[C. C. A.]

"If the habits of this species, as well as some of the preceding, be studied during their whole stay in the State, conclusions will be arrived at that will be in a marked degree at variance with the one popular idea, that 'crow blackbirds' hurt the corn-crop and ought to be exterminated. Without a doubt, these birds do destroy much grain, and prove a great annoyance to the farmer by causing a necessity for replanting, but the corn-hills very probably have suffered fully as much from grubs beneath the surface, as from birds above it. . Not unfrequently has it proved to be the case that the stomachs of blackbirds killed upon cornfields, in May, have revealed masses of semi-digested grubs, and a mere trace of grain.

"If, as is recommended by many, a bounty be put upon every dozen blackbirds killed, and so favor their extermination, then nature's equilibrium will be destroyed, and the unavoidable excess of noxious worms will annihilate the corn-crops. It cannot be too emphatically announced or too persistently maintained, that birds as a tribe are useful, and those apparently least so are suffciently so to warrant their protection rather than destruction. There is no bird of the many found in New Jersey that does not confer actual benefit upon the agriculturist, the nearest approach to an exception being the 'cedar bird ;' and when as in the case of the crow-blacks, at certain times, they are injurious to corn, it is the farmer's duty to devise means of frightening them off, for the time being, and not to destroy them, for it must be remembered that their services are of no mean value, when, following the plow in the spring, they gather up greater enemies to the crops than their necessities ever caused them (the blackbirds) to be."-[C. C. A.]

Q. quiscula æneus, Ridg. Bronzed Grackle.

Plumage of body brassy olive or bronze; neck blue, violet, purple or brassy green; wing coverts without metallic tints; wings and tail violet purple, never bluish; female smaller than male. Length, $12 \frac{3}{4}$ inches; tail, $5 \frac{1}{2}$ inches. Occasional in New Jersey, crossing the Alleghanies or from New England. 


\section{Family FRINGILLID}

\section{Finches.}

A very large family. "One-eighth of all the North American birds are Fringillidoe."-Jordan. "Any one locality of average attractiveness to birds has a bird fauna of over two hundred species, and if it be away from the sea-coast and consequently uninhabited by marine birds, about one-fourth of the species are Sylvicolidoe and Fringillidce together, the latter somewhat in excess of the former."-Coues.

All are granivorous, feeding on seeds, and occasionally berries and insects. Nearly all sing; most are plain, but a few are brilliant of plumage. The bill is short, thick and conical, with the "corners of the mouth drawn down," as in the more slender-billed Icteridoe.

\section{PINICOLA, Vieill.}

P. enucleator canadensis, Cab. American Pine Grosbeak.

Male chiefly red; white wing bars; female brownish yellow on head and rump. Length, $8 \frac{1}{2}$ inches; tail, 4 inches. Northern form, coming south to northern United States in winter.

"Twice has been seen by the author in winter, but is a rare visitant. Those seen by the author were in cedar trees."[C. C. A.]

\section{CARPODAOUS, Kaup.}

C. purpureus, Gmel. Purple Finch.

Tail feathers rounded and soft, none white; male flushed with red, most intense on head and neck, fading below and behind; female olive brown, with no red; bill stout. Length, 6 inches; tail, $2 \frac{1}{2}$ inches.

"Quite common. Irregularly abundant. Prefers hillsides with a southern exposure, and during the winter is found generally in small flocks. Inoffensive."

\section{LOXIA, L.}

(Curvirostra.)

L. curvirostra minor, Brehm. (Curvirostra americana-Abbott's Catalogue). Red Crossbill. American Crossbill.

Points of mandibles crossed, reddish; male brick red, wings unmarked; female brownish olive. Length, 6 inches; tail, $2 \frac{1}{2}$ inches. 
"A northern species that visits New. Jersey in loose flocks about November, and remains throughout the winter. It has been supposed to breed in the State, but it is doubtful. Strictly inoffensive."-[C. C. A.]

L. leucoptera, Gmel. White-winged Crossbill.

Male rose red; white wing bars; female brownish olive, speckled with dusky; rump yellow. Length, $6 \frac{1}{4}$ inches; tail, $2 \frac{1}{2}$ inches.

"Not as common as the above, with which it is generally found associated. Like the above, it may breed in this State, but it is not probable. Graminivorous. Strictly inoffensive."

\section{AOANTHIS, Bechst.}

(퍼giothus-Abbott's Catalogue.)

A. linaria, L. Lesser Redpoll Linnet.

Crown crimson in both sexes; throat, breast and rump rosy in male; chin blackish; much streaked above. Length, 5亲 inches; tail, $2 \frac{1}{2}$ inches.

"A northern species that visits New Jersey during severe winters, and frequently in large numbers. In a measure gregarious. Graminivorous. Strictly inoffensive."

A. linaria rostrata, Coues. Greater Redpoll.

Colors darker and size larger than preceding. A Greenland form that comes south as far as the lower Hudson valley in winter.

A. breweteri, Ridg. Brewster's Linnet.

With no red on top of head; rump rosy in male, yellow in female; is represented by a single specimen taken in Massachusetts in 1870, and is mentioned here that hunters in the northeastern parts of the State may be on the lookout. Should any specimens be found they will be of great scientific importance.

\section{SPINUS, Koch.}

(Chrysomitris, Boie.)

S. trietis, L. Yellow Bird. Thistle Bird. American Goldfinch.

Male rich yellow; rump whitish, white wing bars; black on crown, wings and tail; female more olivaceous; fall plumage 
pale yellow brown; young variously ochraceous, with yellow or not. Length, 5 inches; tail, 2 inches.

"Abundant. Throughout the year this finch remains in loose gangs, and after nidification they wander in flocks of from ten to fifty. Graminivorous. Inoffensive."

8. pinus, Wils. Pine Finch. "Pine Linnet. Pine Siskin.

Sexes alike; plumage thickly streaked; no black on head; bill very sharp; in breeding season plumage suffused with yellow. Length, 43 inches; tail, 2 inches. A northern species. Rare in New Jersey.

"In the depths of winter a few are occasionally seen about pine and cedar trees. Strictly inoffensive."

\section{OARDUELIS, Briss.}

O. carduelis, L. European Goldfinch.

Sexes alike; fore part of head crimson; hinder part of head black; rest of head white and buff; back brown, and upper tail coverts white; wings and tail black, marked with white and yellow; lower parts dull white; sides and flanks cinnamon brown. Length, 5 inches; tail, 2 inches. Introduced from Europe. It breeds in Central Park, New York City, and in parts of adjacent country.

\section{PASSER, Briss.}

P. domesticus, L. European House Sparrow. English Sparrow.

Male chestnut brown above, thickly streaked; ashy below; throat, lores and chin black; female duller, without black; feet small; not streaked below ; wing with two white bands. Lengtb, 6 inches ; tail, $2 \frac{1}{2}$ inches. Nest a bulky structure of dried grasses, lined with feathers, placed in nooks about houses, trees, \&c. Eggs. four to seven, dull whitish, thickly speckled with dark brown and purplish gray. Introduced into the United States 1853, is now so abundant in cities as to be a nuisance. The tree sparrow, also introduced with preceding, has a chestnut crown and is reported as being naturalized about St. Louis. As it is likely to spread, it is one of the furms to be on the lookout for. According to Bulletin No. 1, issued by the Division of Economic Orni- 
thology of the United States Department of Agriculture, the "tree sparrow" is a variety of house sparrow which has taken to trees from being crowded out by too great numbers from available nesting-places in the cities. Sparrows destroy young buds by wantonly picking them off. Their food is anything eatable, and they drive off useful insect-eating birds. The sparrow hawk (Falco sparverius), the northern shrike (Lanius borealis), the blue jay (Cyanocitta cristata), the purple grackle (Quiscalus quiscula), and other birds are its natural enemies, and should be encouraged. The hose should be turned on their nests, to wash and drown them out. They also make excellent pot-pie, and should be shot or trapped for this purpose. Poisoned wheat is an effective but risky destructive agent. Each pair of sparrows raises about twelve pairs of young per year, in about five broods.

\section{PLEOTROPHENAX, Stejn.}

P. nivalis, L. Snowflake. Snow Bunting.

Bill small, with a ruff; hind claw long, but curved; color white in breeding season, with black on back, wings and tail; bill and feet black. In the United States this species is white, clouded with warm brown, and the bill is pale. Length, 7 inches; tail, 3 inches. A northern species, migrating south in winter.

"This beautiful bird is only occasionally seen during very severe winters. But two specimens have come under the author's notice, that were killed within State limits."-[C. C. A.]

\section{CALCARIUS, Bechst.}

C. lapponicus, L. Lapland Longspur.

Bill larger, without ruff; hind claw nearly straight; male with head and throat mostly black; a chestnut collar ; back black and streaky, whitish below; outer tail feathers with white; legs and feet black ; female and winter birds with less black. Length, $6 \frac{1}{4}$ inches; tail, $2 \frac{3}{4}$ inches. A northern form; ranges south in winter, even to the Carolinas at times. 


\section{AMMODRAMUS, Swains.}

A. princeps, Mayn. (passerculus, Bonap.) Ipswich Sparrow.

Outer pair of tail feathers longer than middle pair; bill decidedly compressed; above pale grayish; top of head and back streaked with blackish, margined with pale brown; lower parts white, tinged with buff. Length, $6 \frac{1}{2}$ inches; tail, $2 \frac{1}{3}$ inches. Breeds in Nova Scotia; migrates south as far as the Gulf in winter.

A. sandwichensis savanna, Wils. (passerculus, Bonap.) Savanna. Sparrow.

Sharply streaked; streaks blackish on back; edge of wing yellowish; yellowish stripe over eye. Length, $5 \frac{1}{2}$ inches; tail, 2 inches. Abundant on shores.

"Occurs in New Jersey in May principally. Probably does not breed within State limits. Few seen in September."

A. savannarum passerinus, Wils. (Corturniculus passerinus.) Yellowwinged Sparrow. Grasshopper Sparrow.

Much streaked above; feathers edged with bay ; breast buffy, unstreaked; wings and tail short; edge and bend of wing and line over eye, yellow. Length, 5 inches; tail, 2 inches. Noteis grasshopper-like.

"Quite common. Arrive in April. Frequents fields, especially those skirted by woodland. Nests are placed in low busbes, one brood being raised. None seen in winter."

A. henslowi. Henslow's Sparrow.

Smaller than preceding; more yellow above; black streaks on breast; bill stout; head and neck buffy olive, crown heavily streaked; hind neck narrowly streaked; back and wings chestnut, the feathers black in center and bordered with whitish; belly whitish; chest and sides buffy whitish. Winters in the Gulf States; breeds north of our region.

A. caudacutus nelsoni, Allen. Nelson's Sparrow. Sharp-tailed Finch.

Back sharply streaked; no yellow spot over eye; a bright

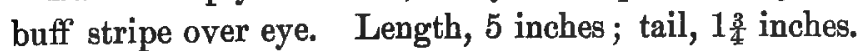

"Like the above, common in Cape May county and 'along 
the shore.' Occasionally seen along the Delaware. Has been killed at Trenton, Mercer county. 'Breeds in the salt meadows."

A. maritimus, Wils. Sea-side Finch, or Sparrow.

Olive gray; back obscurely streaked; a yellow spot over eye. Length, 6 inches; tail, 2 inches.

"Common in Cape May county and along the coast generally. Breeds in the salt marshes, raising two broods."

\section{POOC开THS, Bd.}

P. gramineus, Gmel. Vesper Sparrow. Grass Finch. Bay-winged Bunting. Ground Bird.

Thickly streaked everywhere; slightly buffy below; outer tail feathers white; bend of wing chestnut; tail shorter than wings. Length, 6 inches ; tail, $2 \frac{1}{2}$ inches.

"Abundant. Resident. This 'chippy' is a great lover of fences, and a sociable, lively bird. It builds a nest upon the ground, generally among dewberry vines, raising two broods during the summer. Graminivorous. Strictly inoffensive."

\section{OHONDESTES, Swains.}

C. grammacus, Say. Lark Sparrow, or Finch.

Streaked above, ashy below; crown and ear coverts chestnut, blackening on forehead; with whitish median and superciliary stripes; black lines through and below eye; a black line on each side of white throat; a black breast spot; middle tail feathers like back, the rest blackish and white tipped. Length, $6 \frac{1}{2}$ inches; tail, 3 inches. A western songster, frequenting prairies and river bluffs; occasional on the Atlantic coast.

\section{ZONOTRICHIA, Swains.}

Z. leucophrys, Forst. White-crowned Sparrow.

Streaked above with but little chestnut; crown with broad white median band and a narrow white and narrow black band on each side of it; no yellow anywhere: throat like breast; young with crown rich brown. Length, 7 inches; tail, $3 \frac{1}{4}$ inches.

"Not uncommon in April and in October. Two or three 
occasionally seen together. Does not breed within State limits. Less abundant in autumn than spring."

Z. albicollis, Gmel. White-throated Sparrow. Peabody Bird,

Much chestnut-streaked above; crown black, with white median stripe and white superciliary stripes; a jellow spot over eye and edge of wing; ashy below, whitening on throat; female duller. Length, 7 inches; tail, $3 \frac{1}{4}$ inches.

"More abundant than the above. They are freqently seen together. Arrive in April, and are then more abundant than in October, when they re-appear. None seen in summer."

\section{SPIZELLA, Bonap.}

s. monticola, Gmel. Tree Sparrow.

Streaked above; crown chestnut; bill black above, yellow below; line over eye, lower parts and neck, ashy gray; white wing bars; a dark pectoral blotch. Length, $6 \frac{1}{4}$ inches; tail, 3 inches.

"Resident. Abundant. Though feeding principally on seeds, they not unfrequently prey upon small insects. Of decided value to the agriculturist."

S. socialis, Wils. (domestica, Bartr.) Chipping Sparrow. Chippy. Hair Bird.

Streaked above with dull bay ; crown chestnut; bill, forehead and streak through eye, black; ashy below. Length, $5 \frac{1}{4}$ inches; tail, $2 \frac{1}{2}$ inches.

"Resident. Abundant. Graminivorous. The nest is built in trees generally, two broods being raised during the summer. Strictly inoffensive."

s. pusilla, Wils. (agrestis, Bartr.) Field Sparrow.

Wing usually shorter than tail ; upper parts with more or less of rusty; no dusky streaks on top of head and hind neck, but two rusty lateral stripes on head; back streaked with black on a buffy-grayish ground; rusty spot on side of breast; lower parts whitish, tinged with gray or buff; bill reddish cinnamon; wing bands obscure; general color paler and duller than with S. monticola. Length, $5 \frac{1}{2}$ inches; tail, $2 \frac{1}{3}$ inches.

"Very abundant. Arrives as early as April 1st, and remains 
till late in October. Frequents uncultivated fields, and builds its nest in them, generally on the ground."

\section{JUNĆO, Wagl.}

J. hyemalis, L. Snow Bird. Slate-colored Junco.

No white wing bands; slate gray, darker to blackish on head; female and young tinged with brown; bill pinkish. Length, $6 \frac{1}{4}$ inches; tail, 3 inches. Breeds in the Canadas.

"Makes its first appearance about the middle of November, and remains with us till the middle of March. Frequently their plumage becomes very mottled in March, giving them a handsome appearance. They are graminivorous. Entirely inoffensive. None breed in the State."

\section{MELOSPIZA, Bd.}

M. fasciata, Gmel. (melodia.) Song Sparrow.

Much streaked above and on breast and sides ; crown with an obscure pale median stripe; white below; pectoral streaks form a blotch. Length, $6 \frac{1}{2}$ inches; tail, 3 inches.

"Resident. Abundant. The song sparrow is too well known to need any remarks concerning it. It is found in all parts of the State, even close to the ocean. Strictly inoffensive."

M. lincolni, Aud. Lincoln's Finch, or Sparrow.

Everywhere thickly, sharply and narrowly streaked; breast with broad band of pale buffy or yellowish brown; sides washed with same. Length, $5 \frac{1}{2}$ inches; tail, $2 \frac{1}{2}$ inches. Very shy.

"Very rare, and seen only as a spring visitor. Have seen no specimens during the autumn. Never breeds in the State."[C. C. A.]

M. georgiana, Lath. (palustris, Wils.) Swamp Sparrow.

Crown chestnut; wings tinged with chestnut; few or no streaks on breast and below; tail shorter than in $M$. fasciata; browner in winter. Length, $5 \frac{3}{4}$ inches ; tail, $2 \frac{1}{3}$ inches.

"Not uncommon, and it undoubtedly breeds annually in the Delaware meadows, about Bordentown, where it is frequently seen from April till October." 


\section{PASSERELLA, Ewains.}

P. iliaca, Merr. Fox-colored sparrow. ' Fox Sparrow.

Ashy above, overlaid and streaked with rusty red, which becomes bright bay on rump, tail and wings; white below, with large arrow-shaped spots and streaks, numerous on breast; feet stout, with long claws. Length, 7 inches; tail, 3 inches. Breeds in the Canadas ; migrates early.

"This fine sparrow is more abundant in February than any other month, according to the author's observations. They remain in few numbers during the year, but no nests have yet been seen. Entirely inoffensive."-[C. C. A.]

\section{PIPILO, Vieill.}

P. erythrophthalmus, L. Chewink. Towhee Bunting. Marsh Robin.

Black; belly white; sides chestnut; white markings on tail and wing feathers; iris bright carmine red; in female, head, neck, chest and back brown instead of black. Length, $8 \frac{1}{2}$ inches ; tail, 4 inches.

"Very abundant. Arrives in May, and remains during the summer. Frequents swampy grounds, and is nearly the whole of the time on the ground, except during incubation, when the male birds remain in the trees about the nest, which is always on the ground, and keep guard, warning the hen bird of the approach of danger. Are occasionally seen about gardens, especially where gooseberries are cultivated. Feed exclusively upon insects, and are very strictly an inoffensive species. Retires south in October."

\section{CARDINALIS, Bonap.}

O. cardinalis, L. (virginianus-Abbott's Catalogue.) Cardinal Grosbeak. Redbird.

Clear red; ashy on back ; chin and forehead black ; conspicuous crest; female ashy brown, washed with red. Length, $8 \frac{1}{2}$ inches; tail, $4 \frac{1}{2}$ inches. A brilliant songster.

"Resident. Known generally as 'winter redbird,' and as it frequents leafless bushes, after all other small birds almost have departed, appears to be more numerous in winter than at any 
other season. Build annually in cedar trees, raising but one brood. During the summer spends much of its time on the ground, scratching among the dead leaves. Were it not for its shrill whistle and bright plumage, would, like the 'tanager,' be difficult to detect."

\section{GUIRACA, Swaing.}

G. ccrulea, L. Blue Grosbeak.

Male rich blue; feathers about bill, wings and tail, black; wing bars chestnut; female yellowish brown, with whitish wing

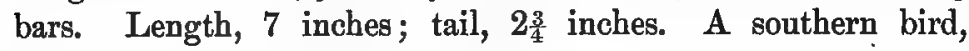
locally rare in summer in our latitude.

\section{HABIA, Reich. \\ (Zamelodia, Coues.)}

\section{H. ludoviciana, L. Rose-breasted Grosbeak.}

Under wing coverts rose red in male, saffron yellow in female ; male with head, neck and upper parts mostly black, with white on rump, wings and tail ; belly white; female olive brown, much streaked; head with whitish bands. Length, $8 \frac{1}{2}$ inches; tail, $3 \frac{1}{4}$ inches. Brilliant in plumage and in song.

"This magnificent bird arrives in May, remaining till October. Not abundant, and, as its plumage is so beautiful, they are eagerly sought after by taxidermists. Their nests are built in closely-leaved trees, one brood being raised. Their food consists of beetles principally, and seeds. They are strictly inoffensive, and should be protected."

\section{PASSERINA, Vieill.}

P. cyanea, L. Indigo Bunting.

Male indigo blue, clear on head, greenish behind; female plain, warm brown, obscurely streaked; a dusky line along the

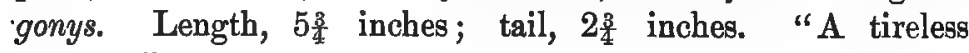
songster."

"Arrives early in May, and is an abundant species. Nidificates in June, building its nest in briar-patches. Prefers unfrequented, woody districts, but is not unfrequently seen in towns. Strictly inoffensive. Disappears in September." 


\section{SPIZA, Bonap.}

S. americana, Gmel. Black-throated Bunting.

Grayish, and streaked above; wing coverts chestnut; line over eye, maxillary stripe, edge of wing, breast and part of belly, yellow; throat patch black; otherwise white below; female with little chestnut, and the black reduced to a few streaks. Length, $6 \frac{3}{4}$ inches ; tail, $2 \frac{3}{4}$ inches.

"Rare. Appears in meadow lands in May, but none probably remain during the summer. Re-appears in September, and remains for several weeks, in few numbers."

S. townsendii, Aud. Townsend's Bunting.

Upper parts, head, \&c., slaty blue; no chestnut, and little yellow or black. Only one specimen known, found in Eastern Pennsylvania.

\section{CALAMOSPIZA, Bonap.}

C. melanocorys, Stejn (bicolor.) Lark Bunting. White-winged Blackbird.

Male in summer black, with slaty tint; white patch on wing; female, above brownish gray, streaked with dusky; lower parts white, streaked on breast and sides with. dusky; patch on wing smaller. In winter, male is like female, though the feathers on belly show black beneath the surface when disarranged. Length, 7 inches; tail, 3 inches. Inhabits the Great Plains; accidental east of Alleghanies.

\section{Family TANAGRID}

\section{PIRANGA, Vieill.}

P. erythromelas, Vieill (rubra, L.) Scarlet Tanager. Fire Tanager.

Middle of cutting edge of upper mandible is toothed; male brilliant scarlet; wings and tail black; no wing bars; female clear olive green above; wings and tail grayish ; greenish yellow below. Length, $7 \frac{1}{3}$ inches; tail, 3 inches. Abundant in woodland. "A respectable songster."-Jordan. 
"Arrives about May 20th, and remains wholly among wellgrown trees. Is much more abundant during some summers than others, although can never be said to be rare. Are shy, restless, and a silent bird. Were it not for the brilliancy of their plumage, would seldom be noticed. They build in trees, generally at considerable elevation, raising but the one brood. They feed principally upon coleopterous insects. Strictly inoffensive. Are largely destroyed by law-breaking 'bird-stuffers,' who well know their value when mounted in a "case of birds." " - [C. C. A.]

P. rubra, L. (æstiva, L.) Summer Redbird, or Tanager.

Cutting edge of upper mandible not toothed; male bright rose red throughout; winga a little dusky; female dull brownish olive above, dull yellowish below; no wing bars. Length, $7 \frac{1}{2}$ inches; tail, 3 inches.

"During the past fifteen years this bird has been emphatically a rare bird, but up to 1850 was almost as numerous as the preceding. Without any decided alteration in the surface of the country generally, or material change in the climate, as compared with twenty years ago, to account for it, we have the statement to make that the summer redbird is now 'rare.' Were we writing in 1845 , we would record it as 'abundant.' The last specimen seen by the author was in June, 1862-a female-ard although the most careful search was instituted, no . other was detected in the neighborhood. On making inquiry in many and distant localities, I have been very frequently assured of their presence, but it has always proved that the 'cardinal' was the bird which they supposed was referred to.- [C. C. A.]

"Breeds in tangled briar-patches, raising a single brood. Have occasionally-not since 1855 -found the nests in cedar trees. They feed largely upon coleopterous insects, and are in nowise injurious to fruit growers. Generally remained during September, though were not found after the appearance of a hard frost."

P. Iudoviciana, Wils. Louisiana Tanager.

The Louisiana tanager has been found accidentally in Massachusetts. The female is as in preceding, but has wing bars; the male is bright yellow, with black tail, and wings black; the head scarlet; yellow wing bars. 


\section{Family HIRUNDINID za.}

\section{Swallows.}

PROGNE, Boie.

P. subie, L. (purpurea-Abbott's Catalogue.) Purple Martin.

Lustrous blue black throughout; female duller; whitish and streaky below; bill stout, nearly hooked. Length, $7 \frac{1}{2}$ inches; tail, $3 \frac{1}{3}$ inches.

"Migratory. Abundant. The martin builds in boxes erected for his accommodation, but has been known to occupy a hollow tree for breeding purposes. They probably destroy more insects than any other one species. Arrive in May, and are generally all gone by the 20th of August."

\section{PETROCHELIDON, Cab.}

P. lunifrons, Say. Cliff Swallow. Eaves Swallow.

Lustrous steel blue; forehead, sides of head, throat, rump, \&c., various shades of chestnut; belly whitish; a blue spot on breast. Length, $5 \frac{1}{2}$ inches; tail, $2 \frac{1}{3}$ inches.

"Abundant, and in some places seem to have taken the place of the barn swallow. Builds under the eaves of buildings, generally under barns and stables. Goes south earlier."

\section{CHELIDON, Forst.}

C. erythrogaster, Bodd. Barn Swallow.

Lustrous steel blue; pale chestnut below; forehead and throat deep chestnut; an imperfect steel-blue collar ; tail deeply forked. Length, 7 inches ; tail, $4 \frac{1}{2}$ inches.

"Very abundant, though probably less so than ten years ago [1858]. Arrive early in May, and remain till the 25th of August, after which they have generally disappeared. Build in barns, and raise generally two broods. Feed exclusively upon insects. Strictly inoffensive."-[C. C. A.]

\section{TACHYOINETA, Cab.}

T. bicolor, Vieill. White-bellied Swallow.

Lustrous green; pure white below; female duller. Length, $6 \frac{1}{4}$ inches; tail, $2 \frac{2}{3}$ inches. 
"Abundant about the coast and along the rivers. Is the species that literally by the million skim over the rivers, crowd the bridges, and sometimes conceal a hundred yards of telegraph, by sitting upon the wires in one unbroken row."

OLIVICOLA, Forst.

(Riparia. Cotyle, Boie.)

C. riparia, L. Bank Swallow. Sand Martin.

Dark gray, not iridescent; white below; a shade of brown on breast. Length, $4 \frac{3}{4}$ inches; tail, 2 inches. A little tuft of feathers at base of hind toe.

"Abundant. A water-loving species, and builds its nest generally in the banks of the river, or about creeks, when far inland. Appears to be rather more abundant in the central and southern portions of the State than in the northern. Arrives late in May, and disappears early in August."

\section{STELGIDOPTERYX, Bd.}

(Cotyle, Boie.)

S. serripennis, Aud. Rough-winged Swallow.

Outer web of first primary saw-like, with a series of weak, small recurved hooks; no tarsal tuft; color brownish gray, darker on wings and tail; lower parts white. Length, $5 \frac{1}{2}$ inches ; tail, $2 \frac{1}{4}$ inches.

"Not an abundant species, and in its habits does not differ from the above. Less seldom seen inland than the 'riparia,' but is more strictly a water-haunting species."

\section{Family AMPELIDz.}

(Bombycillidx-Abbott's Catalogue.)

Wax-wings.

\section{AMPELIS, L.}

A. garrulus, L. Bohemian Wax-wing. Northern Wax.wing.

Tail short and square, tipped with yellow; wings long; color silky, ashy brown, with a red tinge; front and sides of head 
shaded with purplish cinnamon; a black band across forehead and around head; throat black; under tail coverts chestnut red; two white and broad wing bars; bill stout, flattened, notched and hooked ; with wide gape. Length, $77 \frac{1}{3}$ inches; tail, 3 inches.

"A northern species, that is occasionally shot as far south as New Jersey. The author has seen two specimens, one shot in Cape May county, the other in Morris county."-[C. C. A.]

A. cedrorum, Vieill. Cedar Bird. Cedar Wax-wing. Cherry Bird. Southern Wax-wing.

Similar to, but smaller than preceding; less cinnamon tinged; chin black; black stripe across face, bordered above by whitish ; belly yellowish; under tail coverts white; no wing bars; waxlike tips of the wing secondaries, \&c., small or absent in the female. Length, $6 \frac{1}{2}$ inches; tail, $2 \frac{1}{2}$ inches.

"A rambling, apparently useless bird. They remain the greater part of the year in flocks, and destroy large quantities of half-ripe cherries. They build a loose nest of sticks, generally in an apple tree, raising a single brood. They grow very fat in September, and are excellent eating."

\section{Family LANIID As.}

\section{Shrikes.}

\section{LANIUS, L.}

\section{L. borealis, Vieill. Great Northern Shrike. Butcher Bird.}

Clear bluish ash above; black bars on sides of head, not meeting in front, interrupted by white crescent on under eyelid; rump and shoulders whitish; wings black; white below, waved with blackish; both mandibles notched; bill hawk-like. Length, $9 \frac{1}{2}$ inches; tail, $4 \frac{3}{4}$ inches.

"Resident, but not numerous. During the winter they visit, us from the north, and are occasionally very abundant. They feed upon small birds, and killing more than they require, impale them upon thorns." 
L. ludovicianus, var. excubitorides, Swains. Loggerhead Shrike. White-rumped Shrike.

Clear ashy blue; a white superciliary line; black bars on sides of head meet across forehead; no crescent on under eyelid; white below, scarcely dark waved. Length, $8 \frac{1}{4}$ inches; tail, $4 \frac{1}{4}$ inches. Western; sporadic in northern New York. Scarcely to be expected in New Jersey.

L. ludovicianus, L. Loggerhead Shrike.

Slate colored above, darker than in preceding; the rump scarcely paler; black head stripe not bordered above by hoary. Length, $8 \frac{1}{4}$ inches; tail, $4 \frac{1}{2}$ inches. Southern; occasional as far north as Vermont.

\title{
Family VIREONIDEE.
}

\author{
VIREO, Vieill. \\ (Vireosylvia, Bonap.)
}

V. olivaceus, L. Red-eyed Flycatcher, or Vireo.

Bill much as in Lanius; wings long and pointed; slender build; no wing bars; color olive green, with ashy crown, edged with blackish; a white superciliary line, below which is a dusky streak; below, olive shaded; eyes red. Length, $3 \frac{1}{3}$ inches; tail, $2 \frac{1}{2}$ inches. An energetic songster.

"Very abundant. Appears in May, and immediately commences nidification. Builds generally in birches or maples, high up in the trees. Have generally disappeared by September 15th. Prefers trees to bushes, and being strictly insectivorous, is a most valuable bird."

V. philadelphicus, Cass. Pbiladelphia Warbler, or Vireo or Greenlet.

Dull olive green, becoming ashy on crown; no black lines on head; a whitish line on eyebrow; below faintly yellowish, fading to white on throat. Length, $4 \frac{3}{4}$ inches; tail, $2 \frac{1}{4}$ inches. "Scarce."-Jordan.

"Probably not rare. Author has seen but two specimens. In habits very similar to the $V$. gilvus. Strictly inoffensive."[C. C. A.] 
V. gilvus, Vieill. Warbling Flycatcher, or Vireo.

Colors like preceding, but has evidently ten primaries instead of nine apparent, as in the two preceding. Length, $5 \frac{1}{3}$ inches; tail, $2 \frac{1}{4}$ inches. Nests in trees at a considerable height.

"Abundant. Arrives in May, and a few remain during the summer. Re-appears in August and September. Sociable, being frequently seen in shade trees of the streets. Insectivorous."

V. flavifrons, Vieill. Yellow-throated Flycatcher, or Vireo.

Stout build; short bill and feet; white wing bars ; rich olive green above, becoming ashy on rump; bright yellow below; belly white; yellow ring around eye. Length, 53 inches; tail, 2 inches. Only nine primaries apparent.

"More common than the following. Arrives in May, and is found more frequently in open country than in secluded localities. Prefers deciduous to evergreen trees. They breed in June, building their nests at considerable elevation, in maple and elm trees. Have generally disappeared by September 10th. Insectivorous. Inoffensive."

V. solitarius, Wils. Blue-headed Flycatcher, or Vireo. Solitary Greenlet.

Ten primaries apparent; color bright olive green ; crown and sides of head bluish ash ; stripe to and around eye white, a dusky line below it; white below, somewhat washed with pale yellow. Length, $5 \frac{2}{3}$ inches; tail, $2 \frac{1}{3}$ inches. Stout and handsome.

"Not numerous. More generally found in the northern hilly sections of the State. Arrives in May. Some few probably remain. Re appears in September. Prefers woodland."

V. noveboracencis, Gmel. White-eyed Flycatcher, or Vireo.

Wings short and rounded; bright olive green above; white below; sides and under tail coverts bright yellow; wing bars pale; stripe to and around eye yellow; eyes white. Length, 5 inches; tail, $2 \frac{1}{4}$ inches. Found in thickets.

"Uncommon. Seen occasionally in May and again in September. It probably breeds in the State. Strictly inoffensive." 


\section{Family MNIOTILTID 2 .}

Wood Warblers.

MNIOTILTA, Vieill.

M. varia, L. Black and White Warbler or Creeper.

Streaked; colors only black and white; a broad white stripe on crown; white wing bars; female somewhat grayer. Length, 5 inches; tail, $2 \frac{1}{4}$ inches.

"Migratory. Arrives from the South in May, and from the North during the last week in August and in September. Frequents the larger trees-deciduous rather than evergreens-and sings more than many of the migrating species. A few remain during the summer, and are then generally to be found in the dark, silent swamps."

\section{HELMITHERUS, Raf.}

H. vermivorus, Gmel. Worm-eating Swamp Warbler.

Wings longer than tail; olive green; head yellowish, with four black stripes; buffy below; sexes alike. Length, $5 \frac{1}{2}$ inches; tail, $2 \frac{1}{3}$ inches.

"Rare. Seen occasionally in May, but more frequently in September, when the warblers are generally returning to the South. Author knows of no instance of its breeding in the State."-[C, C. A. $]$

\section{HELMINTHOPHILA, Ridg.}

H. chrysoptera, L. Blue Golden-winged Warbler.

Tail feathers blotched with white; back and rump ashy blue; forehead, crown and wing bars bright yellow; throat and broad stripe through eye black; white below ; female duller. Length, 5 inches; tail, $2 \frac{1}{4}$ inches. Throat of female deep gray.

"Unusual. When warblers are more than ordinarily abundant, are occasionally detected. Several were shot in May of 1860 , after a rain of two days' duration."

H. lawrencei. Lawrence's Warbler.

Supposed to be a variety of preceding; has wing bars white and narrower; yellow below; back and rump olive green; throat of female olive greenish. 
H. pinus, L. Blue-winged Yellow Warbler.

Olive yellow; crown and all under parts bright yellow; wing bars whitish ; black stripe from eye to bill ; sexes alike. Length, $4 \frac{1}{2}$ inches ; tail, 2 inches. Resembles a Protonotaria, or Golden Swamp Warbler, but is smaller. The latter belongs to the Lower Mississippi Valley, in willow swamps, and rarely visits the Atlantic coast north of Georgia.

"Not very rare. Seen generally in Cape May county when found in the State. Re-appears in September for a few days. Prefers large evergreen trees, keeping generally near their tops."

H. leucobronchialis, Brewst. Brewster's Warbler. White-throated Warbler.

Probably a variety of preceding, with back and rump ash gray; lower parts white; sides tinged ash gray; wing bands yellow or white, broad or narrow; varies by small gradations into the preceding ( $H$. pinus).

H. peregrina, Wils. Tennessee Warbler.

Olive green; no crown patch; white or slightly yellow below; no white blotches on tail feathers. Length, $4 \frac{1}{2}$ inches; tail, $1 \frac{3}{4}$ inches.

"Rare. Arrives in May and again in September. Author shot a single specimen in July, 1863, but saw no others at that time. Thickly-tangled vegetation is its preferred haunt."[C. C. A.]

H. celata, Say. Orange-crowned Warbler.

Olive green; never ashy on head; orange-brown crown patch more or less concealed; greenish yellow below; female duller. Length, $4 \frac{3}{4}$ inches; tail, 2 inches. Migrates from Alaskan region south through Mississippi Valley. Rare east of Alleghanies.

H. ruflcapilla, Wils. Nashville Warbler.

Olive green; ashy on head and neck; bright chestnut crown patch more or less concealed; bright yellow below ; ring around eye pale. Length, 4 2 inches; tail, 2 inches.

"Moderately abundant. Arrives in May, and again in September. A few remain during the summer. Prefers large deciduous trees, keeping near the tops of them. Strictly inoffensive." 


\section{COMPSOTHLYPIS, Cab.}

(Chloris, Boie. Parula, Bonap.)

C. americana, L. Blue Yellow-backed Warbler. Parula Warbler.

Clear ashy blue; large golden-green patch on back; yellow below; belly white; brown band across breast; white wing bars ; female paler. Length, $4 \frac{3}{4}$ inches ; tail, 2 inches.

"Abundant from the beginning of May. Seldom remains during the summer. Returns in August. Prefers pines and cedars to other trees, and is not as restless as warblers generally are, but remains on one tree for a long time. 'Have found no nests of this species." - [C. C. A.]

\section{DENDROICA, Gr.}

D. tigrina, Gimel. (Perissoglossa, Baird.) Fringed-tongue Warbler. Cape May Warbler.

Olivaceous above, with darker streaks ; rump and sides of neck bright yellow; yellow below, streaked with black; crown nearly or quite black; a white wing patch; orange-brown ear coverts ; female duller, with no reddish or black about head. Length, $5 \frac{1}{2}$ inches; tail 2 inches.

"Arrives in May, but is not an abundant species. Author has met with but two specimens. The common name would seem to suggest New Jersey as its principal 'habitat.' "-[C. C. A.]

D. æstiva, Gmel. Summer Warbler. Golden Warbler. Yellow Warbler.

Plumage chiefly yellow; wings and tail dusky, edged with yellow; back olive yellow; breast and sides with orange-brown streaks; female scarcely streaked. Length, $5 \frac{1}{4}$ inches; tail, $2 \frac{1}{4}$ inches.

"Very abundant. Arrives in May, and remains during the summer. Builds in birch trees, especially those skirting streams, though by no means there exclusively. Is a sociable bird, and seldom seen in the woods or unfrequented swamps. Lives like all the tribe, exclusively on insects, and is a very useful bird to fruit-growers. Have generally all disappeared by September 20th." 
D. corulescens, Gmel. (canadensis-Abbott's Catalogue.) Blackthroated Blue Warbler.

No wing bars; a white spot on primaries near their bases; color rich gray blue, with dusky streaks on back; black throat, neck and sides of body; white below; quills black, edged with blue; female obscurely marked, dull olive green. Length, $5 \frac{1}{2}$ inches; tail, $2 \frac{1}{4}$ inches.

"Arrives earlier than any of the warblers, and is a very common species. Has not been noticed breeding in the State. Reappears in September, and lingers with us till frost."

D. coronata, L. Yellow-rumped Warbler. Myrtle Warbler.

Throat white; crown and rump (and sides of breast) yellow; white and streaked below; wing patch white; no white blotch on primaries; bluish ash above, streaked with black; female and young with less yellow on breast and head; brownish. Length, $5 \frac{3}{4}$ inches; tail, $2 \frac{1}{2}$ inches.

"Very abundant, arriving not unfrequently as early as March. Do not remain during the summer. Appears to prefer the neighborhood of small creeks, though is everywhere to be found, especially where there are large deciduous trees."

D. auduboni, Towns. Audubon's Warbler.

Similar to $D$. coronata, but throat yellow and sides of head dark leaden; no white streaks above and behind eye, but a white spot on each eyelid; male has a large white wing patch ; female with two white wing bars, and chest ashy, spotted with black. Length, $5 \frac{1}{2}$ inches; tail, $2 \frac{1}{3}$ inches. A western species; rare in the east:

"Very rare. Single specimens have occasionally been taken; the last seen by the author was shot May 29th, 1860."-[C. C. A.]

D. malculosa, Gmel. Black and Yellow Warbler. Magnolia Warbler.

Rump yellow; crown clear ash; yellow and streaked below; back black, with olive skirtings; a white stripe behind eye; sides of head black; under tail coverts white; female more olivaceous, with less black. Length, 5 inches; tail, $2 \frac{1}{4}$ inches.

"Arrives early in May, and is one of the most active and restless of the warblers. Seems to have no preference of locality, and is abundant among the shade trees of the cities. None remain during the summer. Re-appears in September." 
D. cœrulea, Wils. Cœrulean or Blue Warbler.

Spots at end of nearly all tail feathers; crown and back blue, with black streaks; white below; no yellow; female greenish above; slightly yellow below. Length, $4 \frac{1}{4}$ inches ; tail, 2 inches.

"Like the castanea, is a rare species, and only to be met with once or twice in a series of springs. Author has killed but one." - [C. C. A.]

D. pennøylvanica, L. Chestnut-sided Warbler.

Much streaked; blackish above; crown clear yellow ; black about eye; pure white below; chestnut streaks along sides; wing patch yellowish (never pure white); female has less black and chestnut. Length, 5 inches; tail, $2 \frac{1}{4}$ inches.

"Common. Arrives about May 1st, and many remain during the summer. Prefers swamps to open ground, and haunts, where it builds its nest, low, tangled vines and bushes."

D. castanea, Wils. Bay-breasted Warbler. Autumn Warbler.

Back black and olive; thickly-streaked forehead and sides of head black, enclosing a deep chestnut crown patch ; chin, throat and sides, dull chestnut; otherwise pale; buffy below; female more olivaceous, with less chestnut; young nearly. like young of D. striata, but more buffy below. Length, 5 inches; tail, $2 \frac{1}{2}$ inches.

"Rarely seen. During the month of May, occasionally a severe northeast storm detains the warblers generally, and when such is the case, the above, with several others, are sometimes seen."

D. striata, Forst. Black-poll Warbler.

Crown pure black; general color black and olivaceous, everywhere streaked; female more olivaceous, and slightly yellow below. Young male olive green, streaked; rump grayish, white and olive; olive yellow below ; flanks rusty; female not streaked, and flanks not rusty. In second year general color is dull gray, streaked; a dull white below, spotted with black. Length, $5 \frac{3}{4}$ inches; tail, $2 \frac{1}{4}$ inches. The last to migrate.

"Very abundant, frequenting elm trees in preference to all others, and remains longer during both spring and autumn, but none have been noticed to remain during the summer." 
D. dominica, L. (superciliosa-Abbott's Catalogue.) Yellow-throated Warbler.

Some yellow on crown; back ashy blue ; cheeks black ; throat yellow; belly white. Length, 5 inches; tail, $2 \frac{1}{3}$ inches. Southern. Very rare in New Jersey. Last one seen by C. C. A. was shot May 29th, 1860.

D. blackburniæ, Gmel. Orange-throated Warbler. Blackburnian Warbler. Hemlock Warbler.

Black above, with whitish streaks; brilliant orange crown patch and throat, fading into yellowish on belly; outer tail feathers white edged externally; female has olive instead of black, and yellow instead of orange. Length, $5 \frac{1}{2}$ inches; tail, $2 \frac{1}{4}$ inches. A most brilliant species.

"Not abundant. Arrives about May 10th, and frequents maple and elm trees principally, keeping among the higher branches. May occasionally remain during the summer. Reappears in September, frequenting deciduous trees."

D. virens, Gmel. Black-throated Green Warbler.

Clear yellow olive; outer tail feathers white edged; sides of head rich yellow; whole throat, breast and sides jet black; whitish below; throat feathers sometimes edged with yellow, especially in the female and winter birds. Length, 5 inches; tail, $2 \frac{1}{4}$ inches.

"Arrives early in May, and frequents city and country alike. Is partial to elm trees. Seldom seen during the summer, though a few breed in the State. Re-appears in September for a few days."

D. _vigorsii, Aud. (pinus,Wils.) Pine-creeping Warbler. Pine Warbler.

Yellow olive above; yellow below; wing bars white; white oblique tail spots at end of two outer feathers only; female more grayish. Length, $5 \frac{2}{3}$ inches ; tail, $2 \frac{1}{3}$ inches.

"Arrive in April, and are most abundant in the southern counties of the State, though numerous everywhere, where pine trees are to be met with. Remains during the summer."

D. kirtlandi, Bd. Kirtland's Warbler.

Ashy blue above; yellow and streaked below; lores black; back brownish gray, streaked with black; wings and tail black, with brownish edgings; in female, the gray on head, rump, \&c., 
is duller. Length, $5 \frac{2}{3}$ inches ; tail, $2 \frac{1}{3}$ inches. Winters in the Bahamas. Summer residence unknown. Rare. Seen during migration.

D. discolor, Vieill. Prairie Warbler.

Olive yellow; patch of red spots on back; forehead, wing bars and belly, yellow; streaked below; sides of head black; sexes alike. Length, 43 inches; tail, 2 inches. Chiefly in evergreen thickets.

"Not very abundant. More numerous during some years than others. Always remains during the summer. Frequents old, uncultivated fields, spending much of its time upon the ground. Sings more, and with a greater variation of notes, than warblers generally. Remains till October."

D. palmarum, Gmel. Yellow Redpoll Warbler. Palm Warbler.

Brownish olive above, somewhat streaked; rump brighter; crown bright chestnut; under parts yellow, with brown streaks; no obvious wing bars (brownish); sexes alike; tail spots square and at ends of two outer tail feathers only; sides reddish streaked. Length, 5 inches; tail, $2 \frac{1}{4}$ inches.

"Arrives early in April, and in loose flocks roam restlessly about dwarfish trees and blackberry briars, frequently in company with other species. None remain during the summer. Re-appear late in August and during September, when they are more scattered and frequent wet, marshy grounds."

D. palmarum, var. hypochrysea, Ridg. Yellow Palm Warbler.

Larger and more brightly colored; entire lower parts bright yellow; upper parts less grayish, but richer olive than in preceding. Length, $5 \frac{1}{2}$ inches; tail, $2 \frac{1}{3}$ inches. Breeds in the Labrador region; southward to Gulf States in winter.

\section{SQIURUS, Swains.}

S. aurocapillus, L. Golden-crowned Thrush. Oven Bird.

Bright olive green; white below; sharply spotted on breast and sides; crown orange brown, with two black stripes. Length, $6 \frac{1}{4}$ inches; tail, $2 \frac{1}{2}$ inches. Builds on the ground or in old logs, stumps, \&c., an oven-shaped nest; has a loud, ringing note; is largest of true warblers; lives in thickets, but spends " most of its time on the ground."-Jordan. 
"Migratory. Abundant. Arrives in April and remains till October. They live along streams of water or about marshes, but spend much of their time in the trees. They are seldom seen on open ground. Strictly inoffensive. Is the most abundant of the three species of Seiurus." - [C. C. A.]

S. noveboracensis, Gmel. (nøevius, Bodd.) Water Wagtail. Water Thrush.

Dark olive brown above; pale yellowish beneath; thickly spotted with color of the back ; feet dark ; bill, $\frac{1}{2}$ inch. Length, 6 inches; tail, $2 \frac{1}{3}$ inches.

"Arrives in May, and occasionally in April, frequenting banks of creeks, and in movements similar to the more abundant ' tiltup.' Breeds in June. Have disappeared by October 1st."

S. motacilla, Vieill (ludovicianus.) Long-billed Water Thrush. Louisiana Water Thrush.

Same general color (less brownish) as preceding, but white or pale buffy below, and less sharply spotted; bill, $\frac{3}{4}$ inch; feet pale. Length, $6 \frac{1}{4}$ inches; tail, $2 \frac{1}{3}$ inches.

"Less numerous than the preceding, but in every way is similar to it in habits. Seldom see more than one of this species, where we find twenty of the noveboracencis."

\section{GEOTHLYPIS, Cab.}

G. agilis, Wils. (Oporornis, Baird.) Connecticut Warbler.

Olive green; ashy on head; brownish ash on throat and breast; yellow below. In fall more olive. Length, $5 \frac{3}{4}$ inches; tail, $2 \frac{1}{4}$ inches. A shy bird.

"Arrives in May, and re-appears in September. Very rare. Author has seen but two specimens. They were taken at different seasons, but upon the same cypress tree. Probably prefers cedar swamps and similar localities, which may account for its so seldom being detected."-[C. C. A.]

\section{G. formosa, Wils. Kentucky Warbler.}

Clear olive green; bright yellow below; crown and sides of head and neck black, with rich yellow superciliary stripe, which bends around eye behind. Length, $5 \frac{3}{4}$ inches; tail, 21 inches. In low thickets in eastern part of Mississippi Valley; rarer east of Alleghanies. Nests on the ground. 
G. philadelphia, Wils. Mourning Warbler.

Bright olive; clear yellow below; head ashy; throat and breast black, the feathers ashy skirted, "as though the bird wore crape." When not in full plumage, both sexes resemble G. agilis, except wing is not longer than tail.

"Arrives in May, and re-appears in September. Rare. Is similar in its movements to $G$. trichas, but seems to prefer low bushes and dwarfed trees rather than the ground. Have detected none during the summer. During the spring of 1860 , when warblers were unusually abundant, saw several, but have seen few since."-[C. C. A.]

G. trichas, L. Maryland Yellow Throat. Black-masked Ground Warbler.

Olive green ; jet-black mask over forehead, sides of head and neck, bordered behind with clear ash; under parts yellow, clear on throat and breast; female without black mask; with less yellow, and with obscure markings. Length, $4 \frac{1}{2}$ inches; tail, $2 \frac{1}{4}$ inches.

"Very abundant. This beautiful bird frequents wet, swampy localities, and passes the greater portion of its time upon the ground. In its movements resembles very much the wren. Builds a nest always upon the ground, raising but a single brood. Sings but little. Have generally all disappeared by September 15th. Like all warblers, is strictly.insectivorous, and destroys an incredible quantity during every twenty-four hours."

\section{ICTERIA, Vieill.}

I. virens, L. Yellow-breasted Chat.

Olive green ; throat and breast bright yellow; belly abruptly white; lores black; white line on eyebrow; tail plain; tarsus nearly "booted." Length, $7 \frac{1}{8}$ inches ; tail, $3 \frac{1}{3}$ inches.

"Very abundant. Arrives early. in May, and remains during the summer. Frequents tangled, bushy vegetation, spending a great portion of its time upon the ground. Is sociable, and frequently seen in gardens, in town, hopping about gooseberry and currant bushes. Breeds in the haunts above mentioned, raising but one brood. Later in the summer, when the young are fully fledged, retire to the woods and swamps, and sing much less than during incubation. The chat is largely known throughout the 
State as the 'yellow mocker,' a name to which it is in no way entitled, as it has no trace of mimicking in its varied notes. Feeds largely upon insects, and is very active and eager in the pursuit of spiders, frequently lying in wait for the large spiders having nests in-to the chat-inaccessible places. They have generally all disappeared by the middle of September."

\section{SYLVANIA, Nutt.}

(Myiodioctes, Aud.)

s. mitrata, Gmel. Hooded (Flycatching) Warbler. Yellow-masked Warbler.

Bright yellow olive; crown and neck jet black, enclosing a broad golden mask; bright yellow below; white blotches on tail ; female with olive instead of black. Length, 5 inches ; tail, $2 \frac{1}{2}$ inches.

"Rare. Arrives in May, and prefers apparently evergreen trees. Re-appears in September and makes a longer stay. Always remains high up among the branches, so is difficult to detect."

s. pusilla, Wils. Wilson's Warbler. Green Black-capped Flycatching Warbler. Green Black-cap Flycatcher.

Clear yellow olive; crown glossy black; remainder of bead and under parts bright yellow; wings and tail unblotched; female with less black. Length, $4 \frac{3}{4}$ inches; tail, $2 \frac{1}{4}$ inches.

"Less rare than the preceding, and unlike it in habits, as it prefers dark, swampy thickets. Has been seen in July, and so may possibly breed here. Re-appears in September for a short time."

s. canadensis, L. Canadian (Flycatching) Warbler. Canada Flycatcher.

Bluish ash; crown speckled with black; under parts clear yellow; under tail coverts white; lores black, continued under eye, and as a chain of black streaks down side of neck, encircling breast like a necklace; wings and tail plain; female with less black. Length, $5 \frac{1}{3}$ inches; tail, $2 \frac{1}{2}$ inches. Very handsome.

"Most abundant of the three species. Arrives in May, and prefers oak woodlands to the open country. None remain during the summer. Re-appear in September." 
SETOPHAGA, Swains.

S. ruticilla, L. American Red Start.

General color black; orange-red blotches on wings and tail and sides of breast; belly white, tinged with red ; female olive; similarly marked with reddish yellow. Length, $5 \frac{1}{4}$ inches; tail, $2 \frac{1}{2}$ inches.

"Abundant. Arrive early in May. A few remain during the summer. They re-appear more numerous than ever late in August and September. Are sociable and as frequent in town as in the country. Show no preference as to the trees they haunt, provided they can supply them largely with insects. Have all gone by October."

\section{Family MOTACILLIDA.}

Wagtails.

ANTHUS, Bechs.

A. pennsylvanicus, Lath. (ludovicianus-Abbott's Catalogue.) American Pipit. Brown Lark. Titlark.

Dark brown, slightly streaked; under parts buffy ; breast and sides streaked; outer tail feathers more or less white. Length, $6 \frac{1}{2}$ inches; tail, 3 inches.

"Migratory. Not abundant. Occur during the months of May and October and November. Do not breed in the State. Gregarious; Frequent plowed fields in May, stubble fields in October."

\section{Family TROGLODYTIDa. \\ Wrens.}

MIMUS, Boie.

M. polyglottus, L. Mocking Bird.

Ashy brown above; wings blackish, with white wing bars; tail blackish, outer feathers white. Length, $9 \frac{1}{2}$ inches; tail, 5 
inches. Tail longer than wing and rounded; tarsus distinctly scutellate.

"Formerly was quite a common summer visitor, but of late years is seldom met with. Author has seen but few specimens during the past seven summers, and has found but the one nest, which has been occupied for three successive summers, and probably by the same pair."-[C. C. A.]

\section{GALFOSCOPTES, Cab.}

G. carolinengis, L. Catbird.

Dark slate color; crown and tail black; under tail coverts brownish chestnut. Length, $8 \frac{3}{4}$ inches; tail, 4 inches.

"Arrives in May and remains until October. Abundant everywhere, and at all times. Builds in trees or bushes, and occasionally on the ground, raising two broods. Feeds largely upon insects and wormy fruit. The catbird is considered very generally a great nuisance by fruit growers, and undoubtedly does carry off much good fruit; but without the shadow of a doubt, it is the wormy fruit that it prefers, and when that is to be had the sound berries or cherries are left undisturbed. If fruit is known to be healthy, it would be better to protect it by fluttering strips of red flannel, or by little flags, than to destroy the catbirds."

\section{HARPORHYNCHUS, Cab.}

H. rufus, L. Brown Thrasher. Sandy Mocking Bird. Brown Thrush.

Cinnamon red above; lower parts thickly spotted; bill nearly straight, shorter and more curved than in allied species of this genus. Length, 11 inches; tail, $5 \frac{1}{4}$ inches. "A brilliant songster."-Jordan.

"Arrives in May and remains in summer. Prefers, woody districts, and is as retired as the catbird is sociable. Builds its nest generally on the ground. Feeds largely upon insects and worms, and is not offensive to the gardener or fruit grower. They sing but seldom, except early in the morning. Return South in October." 


\section{THRYOTHORUS, Vieill.}

T. ludovicianus, Lath. Carolina Wren.

Reddish brown above, brightest on rump; whitish superciliary stripe, bordering a blackish stripe; wings narrowly barred with dusky; pale rusty spots on quills; chin whitish; lower parts tawny. Length, 6 inches; tail, $2 \frac{1}{3}$ inches.

"Rare, and frequenting secluded, tangled thickets. Is but seldom met with, even when several may be in the seeker's neighborhood. Have seen them only in Camden county."[C. C. A.]

T. bewickii, Aud. Bewick's Wren.

Grayish brown ; two middle tail feathers barred. Length, $5 \frac{1}{2}$ inches; tail, $2 \frac{1}{2}$ inches. Belongs to the south and eastern portion of the Mississippi Valley.

"Like the above, this wren is but seldom met with in New Jersey. Appears to be more abundant, however, during some seasons than during others."

\section{TROGLODYTES, Vieill.}

T. aëdon, Vieill (domesticus, Bartr.) House Wren. Wood Wren.

Color brown; brightest behind; rusty below; everywhere more or less waved with darker, especially on the wings, tail, \&c. Very variable. Length, 5 inches ; tail, 2 inches.

"Arrives early in May, and is everywhere abundant, unless it be in dark, unfrequented swamps, for the wren is eminently a social bird, and intelligent above many of its race. Builds in hoxes erected for his accommodation, in deserted woodpeckers' nests-anywhere that affords a certain amount of shelter. Ten eggs are frequently laid, eight always, and two broods are generally raised. Feeds exclusively upon insects, and is as active in their destruction as any of the 'flycatcher' tribe. Have all disappeared by October 15th."

The following is doubtless a mere variety :

"Troglodytes americanus [Abbott's Catalogue]. Wood Wren.

"In all respects, in plumage, movements, and habits generally, is similar to the preceding species, but inhabits the unfrequented woody districts. Arrives and disappears with the aëdon." 
T. hiemalis, Vieill. Winter Wren.

Deep brown, waved with dusky; belly, wings and tail strongly barred. Length, 4 inches ; tail, $1 \frac{1}{4}$ inches.

"During the spring and summer this wren is found only about thick woods, and especially swampy districts. In its movements, restlessness, and apparent love of the ground is much like the common 'bouse wren,' and like it, feeds exclusively upon insects and spiders, hunting diligently for the latter among dead leaves. About October, or later, the winter wren leaves the woods, and in a measure occupies the lately-deserted haunts of $T$. aëdon, remaining about our yards, even in town, during the winter. Occasionally a deep snow drives them to the sheltered swamps, but they promptly re-appear on the disappearance of the snow. The three above-mentioned species of wrens are all inoffensive, and worthy the care and protection of all interested in fruit culture."

\section{CISTOTHORUS, Cab.}

C. palustris, Wils. Long-billed Marsh Wren.

Bill slender, as long as head; a white superciliary line; color clear brown; a black patch, with white streaks, on back; otherwise not streaked above ; crown blackish ; rump brown. Length, 5 :inches; tail, 18 inches.

"Not abundant. Arrives in May, and is found only in the meadow lands, generally in the marshy, wet tracts that are undisturbed throughout the year. Breeds in June, and raises two broods generally. Are most frequently met with in September, when they may be seen flitting about the reeds, apparently careless of the shooting so incessant about them at this time."

C. stellaris, Licht. Short-billed Marsh Wren.

Bill half as long as head; no white superciliary line; color dark brown, head and back darker; entire upper parts with white streaks. Length, $4 \frac{1}{2}$ inches; tail, $1 \frac{3}{4}$ inches.

"More abundant than the preceding, and frequents the same localities. Builds a large globular nest of grass, supported by firm bulrush stalks. Raises two broods in a season, laying frequently ten eggs. This and the above feed exclusively upon 
insects, and are very active in the pursuit of them. Arriving in May, they settle down immediately in the meadows, and do not leave them till a hard white frost has come."

\section{Family CERTHIIDZE.}

\section{Creepers.}

\section{CERTHIA, L.}

C. familiaris americana, Bonap. American Creeper.* Brown Creeper.

Bill slender, as long as head ; without notch or bristles; claws long and curved; tail feathers stiff and pointed, almost woodpecker-like. Plumage dark brown, much barred and streaked; rump tawny. Lenghth, $5 \frac{1}{2}$ inches; tail, $2 \frac{3}{4}$ inches.

"Resident. Although really numerous at all times, is apparently more abundant from October to March than at other times. They usually occupy a deserted woodpecker's nest to breed in. Raise but one brood. Insectivorous. Inoffensive."

\section{Family PARID 2 .}

Titmice.

SITTA, L.

S. carolinensis, Lath. White-breasted [or White-bellied] Nuthatch. [Sap-sucker.]

Ashy blue above; white below; under tail coverts washed with rusty brown; crown and nape black, unstriped; middle tail feathers like back, others black, blotched with white; female with less or no black on head. Length, $5 \frac{1}{2}$ inches; tail, 2 inches.

"Resident. Common. Prefers large trees, but is always to

* The term American Creeper is now not strictly applicable. Ridgway distinguishes a Mexican and two Western forms of this bird as races distinct from our Eastern species. 
be found in greater or lesser numbers in old apple orchards, in which they usually build their nests. Feeds exclusively upon insects and their larvæ. Strictly inoffensive."

s. canadensis, L. Red-breasted [or Red-bellied] Nuthatch.

Ashy blue, brighter than preceding; rusty brown below; crown glossy black in male, bluish in female, bordered by white and black stripes. Length, $4 \frac{1}{2}$ inches; tail, $1 \frac{1}{2}$ inches.

"Resident. Not as numerous as the preceding species. Appears to be more abundant in the winter, but the leafless condition of the trees and the scarcity of birds generally is the reason. Like the above, it feeds only on insects and their larvæ."

\section{PARUS, L.}

P. atricapillus, L. Black-cap Titmouse. Black-capped Chickadee.

Grayish ash; wings and tail plain, with whitish edging; crown, nape, chin and throat black; no white line above eye. Length, 5 inches; tail, $2 \frac{1}{2}$ inches.

"Very abundant everywhere, at all times of the year. Seems to prefer no locality, and is as abundant on exposed upland fields as marshy meadows. Feeds exclusively on insects and their larvæ, and is strictly inoffensive."

P. bicolor, L. Tufted Titmouse.

Forehead alone black; whitish below; sides washed with reddish ; general color lead gray ; a conspicuous crest. Length, $6 \frac{1}{4}$ inches; tail, $3 \frac{1}{4}$ inches. Has a loud, ringing note.

"Very common during the greater part of the year. Has been shot as late as December 3d. Prefers the tallest trees, though not found exclusively in them. Strictly inoffensive."

\section{Family SYLVIIDE.}

\section{Sylvias.}

REGULUS, Cuv.

R. satrapa, Licht. Golden-crowned Kinglet. Golden-crested Wren.

Tarsus booted; wings longer than tail; color olivaceous; crown with a yellow patch, bordered with black (orange red in 
center in male); front of forehead and line over eye whitish; a tiny feather over each nostril. Length, 4 inches; tail, 1 i⿱

"Resident. Common. This species and the next are more abundant during the summer in the northern hilly regions of the State-during the winter equally numerous throughout the State. Both species are inoffensive."

R. calendula, L. Ruby-crowned Kinglet [or Wren].

Olivaceous; scarlet patch on crown in both sexes, wanting the first year; no black about head; no nasal feather. Length, $4 \frac{1}{4}$ inches ; tail, $1 \frac{3}{4}$ inches.

"Resident. Common. During the winter, when birds generally are few in numbers and species, this and the preceding are frequently seen flitting through the leafless branches. During the summer they are shy, and breed in secluded woods."

\section{POLIOPTILA, Sclat}

P. cærulea, L. Blue-gray Fly-[or Gnat-]Catcher.

Clear ashy blue, brightest on head; whitish below; male with forehead and sides of crown black; outer tail feathers chiefly white. Length, $4 \frac{1}{3}$ inches; tail, $2 \frac{1}{4}$ inches. A fine singer; ordinary note squeaky ; manner sprightly.

"Not abundant. Generally to be found, however, on careful search during the summer. Haunts lofty trees."

\section{Family TURDID 2.}

Thrushes.

\section{TURDUS, L.}

T. mustelinus, Gmel. Wood Thrush.

Tarsus booted; wings longer than tail ; color cinnamon brown, brightest on head, shading into olive on rump; breast with large, distinct, dusky spots. Length, 8 inches; tail, 3 inches. An "exquisite songster."

"Abundant from May till October. Prefers thickly-overgrown hillsides, and near water courses, although occasionally 
seen in town. They nidificate in May and raise two broods. They feed exclusively on insects, and are strictly inoffensive. During September, when about to migrate, become slightly gregarious, and generally disappear simultaneously."

T. fuscescens, Steph. Wilson's Thrush. Tawny Thrush. Veery.

Uniform tawny above; breast and throat washed with brownish or pinkish yellow, and marked with small, indistinct, brownish spots. Length, $7 \frac{1}{2}$ inches; tail, $3 \frac{1}{5}$ inches.

"Arrives about May 1st, occasionally earlier, and remains during the summer. Abundant Frequents small trees and bushes, and unlike the following, passes but little of its time upon the ground. Builds a neat nest on or very near the ground, the eggs being laid during the third week in May. Appears less abundant late in the summer, and during September. This is on account of their remaining more in woodlands and tangled thickets than when on their first arrival; they are abundant in the open country. They have generally left by October 15th."

T. aonalaschkæ pallassii, Cab. Hermit Thrush.

Olive brown above, becoming rufous on rump and tail ; breast with numerous, rather distinet, dusky spots; a whitish ring around eyes. Length, 7 inches; tail, $2 \frac{1}{2}$ inches.

"During the month of May, 1859, and in each successive spring, this interesting bird has appeared abundantly in the State, nor has it, as its name would seem to associate, sought only the most secluded localities, but has hopped fearlessly and familiarly about, searching for insects and spiders among the dead leaves, on which insects it exclusively feeds. As it remains during the summer, it undoubtedly breeds with us, but the author has as yet found no nests. During the past summer it has been much less abundant. Although a magnificent singer, the author has heard nothing but a weak chirp issue from its throat, and that seems to be but seldom uttered."-[C. C. A.]

T. ustulatus swainsonii, Cab. Swainson's Thrush. Olive-backed Thrush.

Uniform olive above; breast and throat thickly marked with large, dusky, olive spots; breast and sides of head strongly buffy tinted; a conspicuous buffy orbital ring. Length, $7 \frac{1}{4}$ inches; tail, 3 inches. 
"Quite common, arriving early in May. Are seen occasionally during the summer, and are more abundant in October, when, after a few days' stay, they all disappear. Formerly were more abundant, and the 'hermit' was seldom seen, even as a migratory species. 'Olive-backs' were more abundant during the past summer than for several years" (1867).

\section{MERULA, Leach.}

M. migratoria, L. American Robin, or Red Breast.

Bill bright yellow, notched; sexes alike; olive gray above; head and tail blackish; throat white, with black streaks; under parts chestnut brown; breast, \&c., rufous. Length, 98 inches; tail, $4 \frac{1}{2}$ inches.

"Resident. Abundant, but at certain seasons only. As the specific name indicates, is migratory-perhaps it would be better to say, wandering. Semi-gregarious. Although not uncommon during winter, it is not until the middle of February that they show themselves in numbers. At this time they fly in close flocks, and spend a large portion of their time, if the ground be clear of snow, upon the ground. From now (February) until they pair, their food consists of angle-worms and larvæ of insects; and they remain largely insectivorous during the whole summer, feeding principally upon grasshoppers in August. Nidification takes place in May, two broods being usually raised. In October they have become again gregarious, and feed largely upon the berries of the gum and cedar. At this time they associate to some extent with 'flickers ;' a flock of the former numbering fifty, will be accompanied probably by ten or a dozen of the latter. Are least abundant in December and January. Are in no way objectionable to fruit growers."

\section{HESPEROCICHLA, Bd.}

H. nævia, Gmel. Varied Thrush. Oregon Robin.

Bill not notched; throat unstreaked; sexes unlike; male with a black collar; general color slate; orange brown below; chin, throat and breast orange, rufous or ochraceous. Length, $9 \frac{3}{4}$ inches; tail, 4 inches. Hab.-Pacific Slope. Accidental in New Jersey. 
SIALIA, Swains.

s. sialis, L. Bluebird.

Bright blue above; throat and breast reddish brown; belly white; female duller, with a brownish tinge on back; young are usually spotted. Length, $6 \frac{3}{4}$ inches; tail, 3 inches.

"The 'bluebird' is much less migratory now than in the days of Wilson and Audubon. They are frequently to be seen during the depths of winter, flying from fence-post to post in the country, and singing as cheerfully as in May. They build in ' boxes '.or woodpeckers' nests, raising two broods."

\title{
Order Raptores.
}

\section{Family CATHARTID王.}

\author{
(Vulturidæ.)
}

Vultures.

\section{CATHARTES, Ill.}

O. aura, L. Turkey Buzzard, or Vulture.

Head and part of neck bare; bill lengthened, slender, slightly hooked; wings long and strong; toes somewhat webbed; claws weak; a tuft of bristles in front of eye; plumage black, lustrous above; skin of head and neck red. Length, 30 inches; tail, 12 inches; wings, 22 inches. Voracious scavengers, feeding on carrion and animal refuse of all sorts.

"From Trenton and from New Brunswick, southward, these birds are more or less abundant, becoming more numerous as we approach Delaware Bay and the ocean. Breeds mostly in Cape May county, in unfrequented localities. The opinion entertained by many that lambs and poultry are attacked occasionally by them is not unfounded." 


\section{CATHARISTA, Vieill.}

C. atrata, Bartr. Black Vulture. Carrion Crow.

Wings short; skin of neck corrugated; no bristles in front of eye; uniform dull black. Length, 24 inches; tail, 8 inches; wings, 17 inches. Southern; strays northward. Rarely visits New Jersey.

\section{Family FALCONIDE.}

\section{Falcons.}

\section{ELANOIDES, Gray.}

F. forficatue, L. Swallow-tailed Kite.

Lustrous black; head, neck and lower parts white; tail widely forked, outer feathers twice as long as middle ones. Length, 19 to 25 inches; tail, 14 inches. Southern; accidental on our coast.

\section{CIRCUS, Lac.}

C. hudeonius, L. Marsh Hawk. Marsh Harrier.

Face with a slight ruff; color pale bluish or brown; rump and under parts whitish. Length, 18 inches; tail, 9 inches.

“Known also as 'bog-trotter.' This very abundant hawk prefers meadow lands and appears to be especially abundant along the Delaware River, from Trenton to Cape May. They feed upon mice principally, but are also very active in picking up the wounded reedbirds and 'red-wings' which the gunners fail to gather. 'The nest of this species is placed upon the ground, in tangled marshy thickets, the same being often used several seasons."

ACCIPITER, Briss.

(Nisus, Cuv.)

A. velox, Wils. (fuscus, Gmel.) Sharp-shinned Hawk. Pigeon Hawk.

Tarsus feathered less than one-third down front, the feathers widely separated behind; tarsus "booted" in male; general color dark brown. Length, 12 inches; tail 6 inches. 
"The habits of this species vary but little from that of the next. It is less disposed to attack poultry, preferring mice, and is generally found about swamps and woodland. They breed yearly within State limits."

A. cooperi, Bonap. Cooper's Hawk. Chicken Hawk.

Bare tarsus shorter than middle toe; tail round; back bluish gray; top of head black; female duller in color than male. Length, 18 inches; tail, 8 inches.

"During the spring and early summer is not frequently seen, but from July till midwinter is an abundant, bold and destructive hawk. As is the case with the pigeon hawk, this species is more destructive to poultry than larger species."

A. atricapillus, Wils. American Goshawk.

Tarsus feathered half way down in front; feathers scarcely separated behind; color slate blue, with white stripe over eye; tail with four dark bars. Length, 24 inches; tail, 11 inches.

"Occasionally abundant, but most frequently very scarce; the goshawk appears to be nowhere well known. It seldom frequents the barnyards, but is not unfrequently seen sailing over overflown meadows, especially in March and April. If it breeds within State limits, it is probably in the northern mountainous sections."

\section{BUTEO, Ouv.}

B. borealis, Gmel. Red-tailed Hawk, or Buzzard.

Tail bright chestnut red above; general color dark brown, much barred and streaked. Length, 23 inches; tail, $8 \frac{1}{2}$ inches.

"Known as the 'benhawk,' as well as ' red-tail.' This is the most abundant species found in the State.

"This hawk will never molest poultry if mice are to be caught by them, which is always or nearly so the case, and for this reason this species should be as carefully preserved as it is now persistently destroyed. Fifteen mice have been found in the digestive tract of a single specimen. Breeds in heavy timber, frequently raising two broods."

B. latissimus, Wils. (pennsylvanicus, Wils.) Broad-winged Hawk.

Brown above, whitish below, variously streaked and barred; dark cheek patches; tail with a few broad dark bands, alter- 
nating with narrower pale ones, white tipped.' Length, 18 inches; tail, 7 inches.

"This species appears to be much more numerous during some seasons than others, but being a wary, restless bird, they are frequently more numerous than supposed to be. They breed every season in the hilly, wooded districts."

B. lineatus, Gmel. Red-shouldered Hawk, or Buzzard.

Length, 22 inches; tail, 9 inches.

"Adult.-Shoulders bright red, breast and belly paler, with transverse bands and spots of white. Tail black, with five white bands. Thus plumaged, is known as 'red-shouldered hawk.'

"Young.-Breast and belly yellowish white, with longitudinal bands and spots of brown. Tail brown, with numerous bands of rufous white. Thus plumaged, is known as 'winter falcon.'

"This showy hawk makes its appearance about meadows and small streams generally about October 1st, and is abundant till May, when but few are to be seen. Like B. borealis, this hawk prefers mice to chickens, and should be protected."

\section{ARCHIBUTEO, Brehm.}

A. lagopus, var. sancti-johannis, Gmel. American Rough-legged Hawk. Black Hawk.

Tarsus feathered to the toes, with a narrow unfeathered strip behind; chiefly whitish and rusty, but sometimes entirely black, except forehead and narrow bands on tail. Length, 24 irches; tail, 10 inches.

"From November till April, about meadows and watercourses, this lazy hawk is frequently seen. They are less constantly on the wing than many of the other large hawks. It preys upon mice and rabbits, also poultry, when pressed with hunger. They are sometimes found in gangs, and hunt in company frequently for field and meadow mice.

"Formerly this noble bird was more abundant, but is still by no means rare. The uplands, and especially corn-fields, seem to be favorite haunts of this hawk during autumn, but as winter approaches, especially if there is snow on the ground, they come nearer to the farm-houses, and carry off many and frequently full-grown chickens."

The above species was formerly considered as two species, the 
lagopus and the sancti-johannis. The latter was supposed to be black when adult (and was known as the black hawk), and its young to resemble the lagopus. We now know that the melanistic condition affects certain individuals, both young and old, and that all gradations from black to light are found.

\section{AQUILA, Briss.}

A. chrysaëtos, L. Golden Eagle.

Tarsus entirely feathered to toes; plumage glossy, purplish brown; head and neck golden brown; quills blackish. Length, 36 inches; tail, 16 inches. A northern species.

"Occasionally on the sea-coast, and still more rarely inland, a specimen of this eagle is seen or taken. The young or ' ringtailed eagle' is generally seen during winter on the coast, but they are few in numbers. A specimen was seen by the author near Trenton in April, 1863."-[C. C. A.]

\section{HALI Æ甶UUS, Savig.}

H. leucocephalue, L. Bald Eagle.

Dark brown; head, neck and tail white after the third year. Length, 36 inches; tail, 14 inches. Feeds on fishes, which it often takes by robbing the osprey, or fishing eagle. "Notorious as the emblem of the Republic."-Coues.

"More abundant on the sea-coast than elsewhere within the limits of the State; and breeding in secluded swamps, never very far from good fishing. grounds.

"In Mercer county two or three pairs are generally seen every year, but no nest has as yet been found within the last ten years. They are not an offensive bird to the farmer, and would probably be more abundant were they not so eagerly pursued when seen inland."

\section{FALCO, L.}

F. peregrinus, var. anatum, Bonap. Duck Hawk. Peregrine Falcon.

Upper mandible toothed, lower notched; nostrils circular (as in all falcons); tarsus scarcely feathered below the joint; plumage blackish ash, with paler waves, whitish, and barred below ; black cheek patches. Length, 16 inches; tail, 7 inches. 
"Preferring the sea-coast to inland localities, this bird, better known as 'duck hawk,' is a not unfrequent species. Has been found breeding in Cape May county, the young leaving the nest as early as May 20.th."

F. columbarius, L. Pigeon Hawk. American Merlin.

Inner webs of quills distinctly barred with whitish; tail bands distinct; ashy blue or blackish above, variegated below; female and young whitish or buffy below. Length, 13 inches; tail, 5 inches.

"Not abundant. Is found generally throughout the State, and breeds annually within its limits. This hawk is much more destructive to poultry, especially during the spring, than many of the larger species."

F. sparverius, L. American Sparrow Hawk. Rusty-crowned Falcon.

Back tawny; wings bluish and black; seven black blotches about head; tail chestnut, with a broad black band in male and a narrow terminal one of white; below white or tawny; female more streaky. Length, 11 inches; tail, 5 inches.

"Very abundant, remaining throughout the year. Building a rude nest in the hollow of a tree, two broods are raised during the spring and summer. Though small birds are frequently attacked, mice constitute the bulk of its food."

\section{PANDION, Savig.}

P. haliä̈tus, var. carolinensis, Gmel. American Osprey. Fish Hawk.

Plain grayish brown above; tail more grayish, tipped with white and barred with dusky; head, neck and lower parts pure white, or nearly so, in male; always spotted or blotched with brown in female; feet very large. Length, 24 inches; tail, 10 inches.

"The 'fish hawk' is probably more abundant along the Delaware river than elsewhere throughout the State, except on 'the shore.' It appears along the river in March or late in February, following the herring (Clupea harengus), which then throng the river. They rebuild the nest of the former season, and raise but the one brood generally. The nest is usually at some distance from the parent birds' favorite haunt. During August and through the autumn the fish hawk seeks its food in 
creeks, preying upon pike principally, and in this way only are they objectionable, as occasionally they destroy nearly all the pickerel of a stream that has heretofore afforded the angler excellent sport."

\section{Family STRIGIDE.}

\section{Barn Owls.}

\section{STRIX, '}

s. pratincola, Bonap. American Barn Owl.

Inner toe as long as middle toe; middle claw pectinate; iris black ; tarsus naked, or nearly so ; no ear tufts ; face elongated, reddish or tawny, and variegated with bars and spots.

"Until within a few years this owl was the rarest of the seven resident species. It lives and nidificates in hollow trees, and lives almost exclusively on mice. It is not only an inoffensive, but a most useful bird, and should be carefully protected."

\section{Family BUBONID ż.}

\section{Horned Owls, \&c.}

Inner toe shorter than middle, whose claw is not pectinated; feathers on hinder part of tarsus point downward.

\section{ASIO, Briss.}

A. wilsonianus, Less. American Long-eared Owl. Cat Owl.

Ear opening very large; ears asymmetrical; head with ear tufts; bill dark; face ochraceous; mottled, dusky upper parts; lower parts whitish and irregularly barred. Length, 15 inches; tail, 6 inches. Nest usually the deserted one of a crow or other bird of similar size.

"This owl is probably better known as the 'cat owl.' They are generally found in woody districts and away from meadow 
lands. They feed upon mice, and also capture birds while roosting. They have been known to kill chickens, but such is seldom the case."

A. accipitrinus, Pall. Short-eared Owl.

Ear tufts small; two outer primaries emarginate (one only in preceding); ground color tawny to buffy, striped, but not barred, with brown; face blackish around eyes, eyebrows whitish. Length, 15 inches ; tail, 6 inches. Nest on ground.

"Unlike the preceding species, the 'short-eared owl' appears to be found about meadow lands, preying upon the mice generally there so abundant. They fly in broad daylight with apparent ease when disturbed. Not offensive to the agriculturist."

\section{SYRNIUM, Savig.}

S. nebulosum, Forst. Barred Owl. Swamp Owl.

Bill yellow; no evident ear tufts; iris black; toes not concealed; color olive brown, barred with white above; breast barred and belly streaked. Length, 30 inches; tail, 12 inches.

"Better known as the 'swamp owl.' This species is more abundant in Cape May county than elsewhere within the limits of the State. Shy, and seldom approaches barnyards or poultryroosts. The nest is in a hollow tree, generally at a considerable height. Mice are their principal food."

\section{SCOTIAPEX, Swains.}

\$. cinereum, Gmel. Great Gray Owl.

Iris yellow ; six outer primaries emarginate; toes concealed by long feathers; ashy brown above, waved with white; breast streaked, belly barred. Length, 30 inches; tail, 12 inches.

"A single specimen has been taken in Sussex county, in December, 1859. Only a very rare visitor."

\section{NYOTALA, Brehm.}

N. acadica, Gmel. Saw-whet Owl.

No ear tufts ; iris yellow ; nostrils prominent, nearly circular, open anteriorly; brown above, spotted with white; white below, 
striped with reddish brown; feet whitish buff. Length, 8 inches ; tail, $2 \frac{3}{4}$ inches.

"This is now a rare species of owl. It is generally found in cedar trees, and flies very readily when disturbed. It feeds exclusively upon insects, and is a strictly inoffensive species; but, being an owl, a disgraceful prejudice on the part of most people prompts to its destruction."

\section{MEGASCOPS, Kaup.}

M. asio, L. Screech Owl. Little Red Owl. Gray Owl.

Speckled and barred; the ground color gray or bright red, the two colors bearing no relation to age, sex or season. Length, 10 inches; tail, $3 \frac{1}{2}$ inches.

"This is the best known of all the owls, and has several names besides the one above, as 'little red owl,' 'gray owl,' \&c. The two conditions of plumage, red and gray, give rise generally to the belief that they are two distinct species. This, however, is erroneous. The screech owl is more frequently found in orchards than elsewhere, but is everywhere abundant. The nest is always in a hollow tree. They fly about during the day very frequently. The food is mice and insects. They are entirely inoffensive."

\section{BUBO, Dum.}

B. virginianus, Gmel. Great Horned Owl.

Bill blackish ; conspicuous ear tufts, of blackish feathers; iris yellow; plumage dark colored, black, gray and buffy; no stripes; lower parts barred; above variegated ; usually a whitish half collar. Length, 22 inches; tail, 10 inches.

"In the northern and southern sections of the State this owl is not uncommon. In the central counties it appears only as 'stragglers.' They haunt secluded swamps, near water-courses, and not unfrequently visit poultry-yards, coming a great distance."

\section{NYCTEA, Steph.}

N. nyctea, L. (scandiaca, nivea, \&c.) Snowy Owl.

Iris yellow; bill black; toes concealed by long feathers; facial disk incomplete; plumage pure white, with blackish bars. 
Length, 23 inches; tail, 10 inches. A northern form, ranging south in winter. The female has only the front aspect white, the other parts more heavily barred with dark than in male.

"The snowy owl visits New Jersey almost every winter, and not unfrequently they remain throughout the year. Their diurnal habits, large size and snowy plumage render them an easy prey to the gunner, however, and they are soon all destroyed. Their food is mice."

\section{SURNIA, Dum.}

S. ulula, L. (funerea), var, caparoch, Müll. American Hawk Owl. Day Owl.

No ear tufts; iris and bill yellow; plumage brown, much speckled and barred; whitish below. Length, 16 inches; tail, 7 inches. A northern species.

"This is, as the 'great gray owl,' a very rare winter visitor. The author knows of but two instances of its being taken in the State-in Mercer county, in 1858, and in Middlesex county, in 1861."-[C. C. A.]

\section{SPEOTYTO, Gloger.}

S. cunicularia, var. hypogæa, Bonap. The Burrowing Owl.

With nearly naked tarsus; imperfect facial disk; simple middle claw; spotted and variegated brown plumage. Length, 10 inches; tail, 4 inches. Belongs to the western plains, living in the burrows of the prairie dog, and has been accidentally conveyed to New York and Massachusetts; might possibly also, at times, be found in New Jersey. 


\section{Section CURSORES.}

\section{Order columbae.}

Pigeons.

\section{Family COLUMBIDA.}

Doves.

\section{ECTOPISTES, Swains.}

E. migratorius, L. (macrura.) Passenger Pigeon. Wild Pigeon.

Tarsus feathered at the heel (tibio-tarsal) joint; tail of twelve feathers, long and wedge shaped; plumage bluish, with reddish and violet tinges; reddish below. Length, 17 inches; tail, 8 inches.

"The wild pigeon is much less abundant than formerly. A few can generally be found where there is a preponderance of beech timber, which is always a favorite sort. Incubation takes place during May and June, occasionally three broods being raised. They appear in flocks of from fifty to five hundred, during August and September, and when they are ripe they live largely upon beech-nuts. The decrease in their numbers has been steady during the past ten years, and they will probably be among 'the things that were,' in this State" (1868).

\section{ZENAIDURA, Bonap.}

Z. macroura, L. (carolinensis.) Turtle Dove. Carolina Dove. Mourning Dove.

Tarsus bare; tail of fourteen feathers; plumage brownish olive, glossed with blue and wine color; with metallic luster. Length, 12 inches; tail, 6 $\frac{3}{4}$ inches.

"Resident. Abundant. The dove is not apparently very numerous till the grain is harvested, then they are found in loose flocks on the stubble, and are very fat. Though a grain-eating species and at times very numerous, they are not offensive." 
COLUMBA, L.

C. livia. Rock Dove. Domesticated Dove.

Of numerous varieties and breeds, whose description does not belong to a catalogue of this sort.

\section{Order Rasores}

(OR GALLINE.)

\section{Family TETRAONID $z$.}

\section{Grouse.}

COTURNIX, Bonnat.

(Tetrao, L.)

O. coturnix, L. European Quail.

Tarsus naked nearly to joint; sides of toes not pectinated; cutting edge of lower mandible without serrations; tail very short; above light brown, streaked with buff bordered by black, on back and rump; wing coverts barred with dusky and buffy; breast cinnamon brown, with dusky spots; buffy below; a dark patch on throat (absent in female). Length, 7 inches.

\section{COLINUS, Less.}

\section{(Ortyx, Steph.)}

C. virginianus, L. Quail. Bob White (known as "Partridge," South.)

Nostrils unfeathered, protected by naked scale; tarsus bare and scutellate; head not crested; plumage generally chestnut red, barred and streaked; forehead, line through eye, chin and throat, white in male, brownish yellow in female. Length, $9 \frac{1}{2}$ inches; tail, 3 inches. Similar to grouse, but smaller.

"Resident. Abundant. Quails couple about the first of May, and build a large nest of grass, on the ground, laying from ten to fifteen eggs. A second brood is not usually raised. Weasels are the most destructive enemies they have, not only eating the eggs, but frequently killing the hen bird. The young are on the wing by August, although their flight is feeble till the middle of 
September. Two broods frequently associate and as a 'covey' remain in the neighborhood of the nests the greater part of the fall, unless driven off and thinned out by the gunners. Severe winters are very destructive to quails, and deep snows have done much probably towards 'thinning them out.'"

\section{BONASA, Steph.}

B. umbellus, L. Ruffed Grouse. Partridge (North). Pheasant (South). Tarsus feathered half way; tail of eighteen soft, broad feathers; head crested; sides of neck with ruff of dark feathers (smaller in female); plumage variegated, reddish or grayish brown, with blackish and pale. Length, 18 inches; tail, 7 inches.

"Resident. Gradually being exterminated. The pheasant is probably most abundant in Monmouth and Ocean counties, but the law protecting them being totally disregarded, they are not numerous in those localities. The grouse pair off in May, and raise one brood, which are weak on the wing in August, but nevertheless are eagerly pursued by pot-hunters. Numbers from other localities have occasionally been 'planted' in New Jersey, but certain gentlemen (?) who have no idea beyond their bellies, frustrate these attempts to stock the State, by 'out of time" shooting."-[C. C. A.]

\section{TYMPANUCBOS, Glog.}

(Cupidonia, Reich.)

T. cupido, L. Prairie Hen, or Chicken ; more properly, Heath Hen.*

Scapulars with large terminal spots of buffy white (no such spots in $T$. americanus); neck tufts of male sharply pointed, lanceolate (rounded in americanus); beneath neck tufts a patch of bare red skin, capable of great inflation; plumage black, tawny and white, barred and streaked; female smaller, with rudimentary neck tufts. Length, 17 inches; tail, 4 inches. Now left only on Martha's Vineyard, where it is in danger of extermination. Formerly abundant along Atlantic coast.Ridgway.

"A few only remain in Monmouth county and in Ocean

* The true prairie chicken is $T$. americanus, and does not range east of Indiana. 
county, but so very few that it is perhaps hardly correct to consider it as any longer represented in the State fauna. Formerly it was very abundant throughout the State. Several attempts. have been made to restock the State with this species, and in a measure these attempts would be successful, but it appears impossible to prevent them from being shot during May, when they are breeding, and are comparatively tame" (1868).

\section{Family phasianidz.}

Turkeys.

MELEAGRIS, L.

M. gallopavo, L. Wild Turkey.

Glossy, coppery black. Length, 48 inches; tail, 18 inches. Now extinct, or nearly so, in the more-settled regions of the Atlantic coast. Our domestic turkey is descended from a Mexican variety.-Jordan.

G. bankiva.

\section{GALLUS.}

The jungle fowl of India, supposed to be the ancestral stock from which our domestic fowls ( $G$. domestica) have been derived. A description of the races and breeds is foreign to this list. Other species commonly kept in a domesticated state and derived from Asiatic or African species, are Pavo cristatus, the peacock; Numida meleagris, the guinea fowl ; Phasianus colchicus, common pheasant. 


\section{Order GRALLATORES.}

Wading Birds.

\section{Sub-Order GRALle-limicole.}

Shore Birds.

\section{Family Phalaropodid}

\section{Phalaropes.}

\section{PHALAROPUS, Briss.}

P. tricolor, Vieill. (Steganopus wilsoni, Sab.) Wilson's Phalarope.

Snipe-like; toes with narrow, plain lobes; ashy above, variegated; rump and under parts white; sides of neck with black stripe, which changes to chestnut below; swimmers; northern; male smaller and duller than female; winter plumage different. Length, $9 \frac{3}{4}$ inches; wings, $5 \frac{1}{4}$ inches ; tarsus, $1 \frac{1}{3}$ inches.

"Rare. Specimens of this phalarope are very seldom taken in the State; when taken, it is as a single specimen, and always on the sea-board. A specimen killed at Deal, Monmouth county, and one at Atlantic City, are the only two that the author has met with." - [C. C. A.]

P. lobatus, L. (Lobipes hyperboreus.) Northern Phalarope.

Bill awl shaped; toe membranes scalloped; plumage grayish black, variegated with buff; stripes on back; wings dusky, greater coverts tipped with white; rump and under parts white; sides of neck with a chestnut stripe; northern. Length, $7 \frac{1}{2}$ inches ; tarsus, $\frac{3}{4}$ inch.

"More frequently met with, and occasionally seen inland, a specimen having been shot by the author on the Delaware, at the mouth of the Rancocas Creek. When found, it is generally in company with other birds of similar habits, especially on the sea-shore."-[C. C. A.] 


\section{GRYMOPHILUS, Vieill.}

C. fulicarius, L. Red Phalarope.

Bill flattened; membranes of toes scalloped; lower parts purplish cinnamon; sides of head white; top of head dark (streaked with buffy in male); back buffy, striped with black; male smaller than female. Length, 8 inches; tail, $2 \frac{3}{4}$ inches; tarsus, $\frac{4}{5}$ inch ; bill 1 inch. Breeds far northward. In winter, ranges south to Middle States and Ohio Valley, and then plumage is different; lower parts white; head white; back uniform pearl gray.

"About as numerous as the preceding. It arrives on our seaboard in May, and soon suddenly disappears, to re-appear in August, during which month they are most numerous. Author has seen a specimen, shot June 27th, 1863, on the Hackensack River."-[C. C. A.]

\section{Family RECURVIROSTRIDE.}

\section{Avooets.}

\section{REOURVIROSTRA, L.}

R. americana, Gmel. American Avocet. Blue Stocking.

Legs blue, long; bill slender, recurved, flattened and tapering to a needle point; toes four, full webbed; plumage white, marked with cinnamon on wings; head tinged with gray in winter. Length, 18 inches; tai], $3 \frac{1}{2}$ inches; tarsus, $3 \frac{3}{4}$ inches.

"Common along the sea-board, more especially at Egg Harbor. Frequents shallow pools in the salt meadows. Breeds in the long grass, generally selecting a tuft in which to place the nest. Never seen inland, nor about the bay shore. Known frequently as "blue-stockings." "

\section{HIMANTOPUS, Briss.}

ㅍ. mexicanus, Müll. (nigricollis-Abbott's Catalogue.) Black-necked Stilt. Long-shanks. Lawyer.

Toes three, semipalmated; bill nearly straight, not flattened; legs pink; forehead, cheeks and lower parts white; iris crim- 
son; tail ashy ; rest of body glossy greenish black. Length, 15 inches; tail, 3 inches; tarsus, 4 inches.

"Not as numerous as the preceding species, but by no means rare. Arrives in May, and is again more plentiful in August. Some few breed in the salt marshes, building a nest of grass, in grass. They are similar to the preceding in their habits. Known often as "lawyers." "

\section{Family SCOLOPACIDZE.}

\section{Snipe.}

PHILOHELA, Gray.

P. minor, Gmel. American Woodcock.

Toes not webbed; bill straight, longer than head; first three primaries attenuate; eye high and far back; plumage variegated brown, gray, russet, with black spots; below warm brown. Length, 11 inches; bill, 3 inches ; tarsus, $1 \frac{1}{4}$ inches.

"Very abundant in some sections of the State. Never found very far from farm-houses. Builds a nest of grass, nearly on the ground, sometimes as early as March. Raises two broods, the young of the latter brood not often able to fly by July 5th, when wise (?) legislation permits them to be shot. Disappear and moult in August. Re-appear in September, a wary, strong bird. In the summer, haunt willow hedges. In October, drier ground, generally hillsides."

\section{SOOLOPAX, L.}

S. rusticola, L. European Woodcock.

First primary, only, attenuate; general appearance of preceding, but larger. European. Accidental on Atlantic coast.

\section{GALLINAGO, Leach.}

G. delicata, Ord. (wilsoni, Temm.) Wilson's Snipe. American Snipe. Toes not webbed; primaries not attenuate; bill straight, about twice as long as head; back blackish, varied with bay; crown 
black, with pale median stripe; tail feathers sixteen. Length, 11 inches; bill, $2 \frac{1}{2}$ inches; leg, naked, 3 inches; tail, $2 \frac{1}{3}$ inches. "Arrive in March, frequenting meadows exclusively. At this time, generally in loose flocks. The 'killdeer' always heralds their arrival. The greater part pass on to the North, but numbers remain, building nests in long grass, most frequently about springs in the upland, raising but one brood. Returning from the North, they reach us during the latter part of September and in October. A few not improbably remain during the winter."

\section{MAORORHAMPUS, LeBch. '}

M. griseus, Gmel. Gray Snipe. Brown-back Dowitcher, \&c.

Toes webbed at base; rump white and barred; tail slaty, barred with white; sides of neck, chest, \&c., light cinnamon, speckled with dusky; belly white; top of head streaked with buffy and dusky; back variegated with pale cinnamon and dusky; in winter plumage is more whitish and ash gray. Length, $10 \frac{1}{2}$ inches ; tarsus, $1 \frac{1}{3}$ inches. Breeds in Northeastern North America. Sometimes confused with next.

M. scolopaceus, Say. Red-breasted Snipe. Long-billed Dowitcher, \&c.

General characters same as preceding, but entire belly and breast bay in summer, white in winter ; sides barred with dusky. Length, 12 inches; tarsus, $1 \frac{1}{2}$ inches. Breeds in Northwestern North America. Bill, 28 inches (culmen); longer than in preceding.

"Called 'dowitcher' very generally along the shore. Arrives in April, and frequents the beach, and bog meadows. They reappear late in $\mathrm{J}$ aly, and are found in great numbers till late in September. Author has found them most abundant about Tuckerton. Frequently called 'brown-backs.' "-[C. C. A.]

These are considered as two species by Ridgway, as one by Jordan, Abbott, \&c.

\section{MICROPALAMA, Bd.}

M. himantopus, Bonap. Stilt Sandpiper.

Toes webbed at base; tail not barred; bill straight, nearly twice as long as head; upper parts blackish, varied with gray and buff; top of head dusky, streaked with white; lower parts 
whitish, barred with dusky ; winter plumage ashy gray. Length, 9 inches; tail, $2 \frac{1}{4}$ inches; culmen, $1 \frac{3}{4}$ inches.

"Not numerous. Are seen generally in company with allied species. Single specimens have been killed in the Delaware at Trenton, accompanying 'jack snipe.' Do not breed in the State."

\section{TRINGA, L.}

T. canutus, L. Robin Snipe. Knot. Red-breasted Sandpiper.

Tarsus not shorter than middle toe; tibia bare below; bill straight; plumage brownish black above, brownish red below; Length, 11 inches; tail, $2 \frac{1}{2}$ inches.

"Arrive in May, and after a few days spent upon the beach, they have all gone, to re-appear in August, when they make a longer stay. Have sometimes found this species inland."

T. maritima, Brïnn. Purple Sandpiper.

Tarsus shorter than middle toe; tibia feathered (Sub-genus Arquatella); color ashy black, with purple reflections; feathers with pale edgings; lower parts mostly white; bill nearly straight.

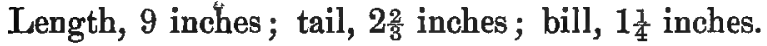

"Very rare in New Jersey. Prefers rocky sea-coast to the sandy beach. Author has seen but one specimen. It was found dead upon the beach, near Absecom lighthouse."-[C. C. A.]

T. maculata, Vieill. Pectoral Snipe, or Sandpiper. Jack Snipe. Grass Snipe.

Bill, tarsus and middle toe (with claw) of about equal length (Arctodromas); throat ashy and sharply streaked; above light clay color, broadly striped. with black; lower parts and chin white; chest buffy gray and streaked; crown unlike neck; upper tail coverts dark. Length, 9 inches; bill, $1 \frac{1}{8}$ inches.

"Arrives in April. Re-appears in August. Very abundant, and known as 'fat-bird.' Frequently seen in flocks on the Delaware, at Trenton."

T. fuscicollis, Vieill. Bonaparte's Sandpiper. White-rumped Sandpiper.

Upper tail coverts all white, sometimes marked with dusky; in winter, upper parts plain brownish gray, with indistinct streaks; in summer, top of. head buffy, broadly streaked with black; back brownish gray and buffy, tinged with rusty and 
striped with black; lower parts white. Length, $7 \frac{1}{2}$ inches ; tail, $2 \frac{1}{4}$ inches.

"Abundant both on the coast and inland. During spring freshets frequents the overflowed meadows of the Delaware though in August is found only on the river shore."

T. minutilla, Vieill. Least Sandpiper. Peep.

In winter, plain brownish gray, with dusky streaks; chest pale gray, streaked, and lower parts white; in summer, top of head rusty ochraceous, streaked with black; chest brownish white, streaked; rump and upper tail coverts brownish black. Length, 6 inches; tail, 2 inches.

"Very abundant both on the coast and inland. Arrives in May, and re-appears in August. When found in spring or autumn, is always in flocks ranging from ten to fifty."

T. bairdii, Coues. Baird's Sandpiper.

Colors of preceding, but larger; throat but little streaked. Length, $7 \frac{1}{2}$ inches ; tail, $2 \frac{1}{4}$ inches. Rare east of Mississippi River.

T. alpina, var. paciflca, Coues (var. americana, Cass.) Red-backed Sandpiper. American Dunlin. Oxbird. Black-bellied Sandpiper.

Bill slightly decurved; tibia bare below; plumage chestnut brown above; belly, in summer, with a black area ; breast white. Length, 9 inches ; tail, $2 \frac{1}{3}$ inches ; bill, $1 \frac{3}{4}$ inches ; tarsus, 1 inch.

"Arrives in April, but makes a limited stay only. Re-appears in August, and throughout September is very plentiful. Has been shot on the Delaware, at Trenton."

T. ferruginea, Brünn. (Ancylocheilus subarquata-Abbott's Catalogue.) Curlew Sandpiper.

Tarsus one and a half times as long as middle toe; upper tail coverts entirely white; head, neck and lower parts rufous in summer; upper parts varied with blackish and rusty; in winter, upper parts plain brownish gray. Length, 8 inches; tarsus, $1 \frac{1}{6}$ inches. European, but occasional on this side of Atlantic.

"Like the maritima, this is a rare species, though not to the same extent. Specimens have been found at Tuckerton and Cape May. Never seen along the rivers, nor on the shores of Delaware or Raritan Bays." 


\section{EREUNETES, Ill.}

E. pusillus, L. Semipalmated Sandpiper. Peep.

Grayish brown, tinged on sides of head, \&e., with pale buffy cinnamon; chest narrowly streaked with dusky; white below. Length, $6 \frac{1}{2}$ inches; tail, 2 inches. Bill about as long as head (culmen, $\frac{3}{4}$ inch); middle toe webbed at base.

"Arrive in New Jersey early in May, occasionally in April, and although many go north, a great number remain during the summer. Abundant on the coast. Numerous inland. Prefer meadow lands inland to the river shore, but are more abundant on the beach, on the coast. Go south in October."

E. occidentalis, Lawr. Western Sandpiper.

Summer adult with upper parts rusty, the feathers spotted centrally with black; stripe of rusty on head; chest and breast marked with broad streaks; bill longer in female, where culmen is 1 inch. Breeds in Northwestern North America; occasional on Atlantic coast during migrations; probably confused with preceding.

\section{CALLIDRIS, Cuv.}

C. arenaria, L. Sanderling. Ruddy Plover.

Form of $T$. canutus, but with only three toes, the hinder one absent; belly very white; above variegated rusty, white and dusky ; more grayish in winter. Length, 8 inches; tail, $2 \frac{1}{4}$ inches.

"Never appears on our coast as abundantly in spring as in autumn. Prefers the border of the ocean to meadows, and goes in flocks, or in company with sandpipers. On the Delaware River, at Trenton, and on the Raritan, at New Brunswick, they are frequently killed in August and September. When thus found, they are accompanying sandpipers."

\section{LIMOSA, Briss.}

L. fedoa, L. Grent Marbled Godwit. Marlin.

Toes somewhat webbed at base; tail barred crosswise with light and dark colors; no pure white, but cinnamon brown, variegated above with bars and spots; uniform below; head and 
neck streaked. Length, 16 to 22 inches; tail, $3 \frac{1}{2}$ inches; bill, $4 \frac{1}{2}$ inches.

"Known generally as the 'marlin.' Arrives in May, and re-appears in September. Flies always in flocks, and is a wild bird. Frequents the bays rather than beach. Never seen inland."

L. hæmastica, L. (hudsonica-Abbott's Catalogue.) Hudsonian Godwit. [Improperly, Black-tailed Godwit.] Ring-tailed Marlin.

Tail black, white at base and tip; head and neck pale chestnut, streaked with dusky; lower parts deeper chestnut, barred; back blackish, variegated with buffy; winter plumage brownish gray above; head and lower parts grayish white. Length, 15 inches; tarsus, $2 \frac{1}{2}$ inches; bill, $3 \frac{1}{2}$ inches.

"Known as the 'ring-tailed marlin.' Arrives also in May, and re-appears in September. Is not as abundant as the preceding, whose habits are the same as the species under consideration."

\section{TOTANUS, Bechs.}

T. melanoleucus, Gmel. Greater Yellow-legs. Greater Tell-tale. Yellow-shanks. Stone Snipe.

Legs long, yellow; tarsus, $2 \frac{3}{4}$ inches; inner web of toes very small ; bill very slender, $2 \frac{1}{4}$ inches, not curved; rump grayish, spotted with dusky ; flanks barred with dusky ; in summer, grayish, spotted with white above, barred with dusky below (except on belly); in winter, lighter.in color. Length, $12 \frac{1}{2}$ inches; tail, $3 \frac{1}{4}$ inches.

"Arrive in May, and a few remain during the summer. Are abundant again in August. Frequent the Delaware, and occasionally very large flocks are seen on the river, but generally they are associated with the following species."

T. flavipes, Gmel. Lesser Tell-tale. Yellow-legs. Yellow-shanks.

Colors as in preceding; smaller; legs longer (proportionally).

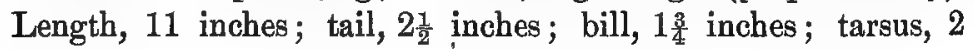
inches.

"Very abundant. Arrive along our coast and rivers in May; a few remain during the summer, and re-appear in August. Generally fly in immense flocks. On the Delaware are most numerous in Angust, and are then much wilder than in May. None seen after October 15th." . 
T. solitarius. Solitary Tattler, or Sandpiper.

Inner web of toes rudimentary; legs blackish; bill straight and slender; white below, breast with dusky suffusion; above olive brown, streaked and speckled with whitish. Length, 9 inches ; tail, $2 \frac{1}{2}$ inches ; bill, $1 \frac{1}{4}$ inches.

"Arrives about the 1st of May, and single specimens are scattered over meadow lands throughout the State. Is much more abundant during some seasons than others. Builds a nest of grass on the ground, raising but one brood. Congregate on river shores in August, and have all gone by September 15th."

\section{SYMPHEMIA, Raf. \\ :S. semipalmata, Gmel. Willet. Semipalmated Tattler.}

Legs dark or bluish; toes distinctly webbed at base, even between inner and middle toe; quills blackish, with basal half white, producing a white patch at base of spread wing; in summer, plumage brownish gray above, varied with dusky; below whitish, varied with dusky on chest and sides; in winter, ash gray above, white below. Length, 12 to 16 inches; tail, 3 inches; bill, $2 \frac{1}{2}$ inches.

"Arrive in May. Abundant. Breed in the salt marshes, building a nest of grass. Are very noisy, especially during incubation. Are easily decoyed by imitating their whistle. Fly in large flocks, and seldom associate with other birds. Have never seen specimens on our rivers."

\section{PAVONCELLA, Leach.}

(Machetes, Cuv.)

\section{P. pugnax, L. Ruff (male). Reeve (female).}

Web at base of toes; plumage black, buff and gray above; white below and on sides of rump, varied on chest; middle tail feathers barred; great variation of color in male, scarcely two alike ; provided with a "cape," which is usually black, but may vary to whitish ; also has a "ruff," usually chestnut, either plain, streaked or barred; face bare; no ruff or cape in the female; head completely feathered; plumage barred with black, buff, white and rusty; white below. Length, 12 inches; tail, $2 \frac{1}{2}$

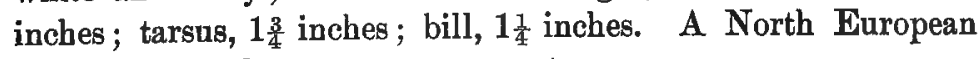
form, occasional on our eastern coast. 
BARTRAMIA, Less.

B. longicauda, Bechs. (Actiturus bartramius-Abbott's Catalogue.) Bartramian Sandpiper. Field Plover. Upland Plover.

Above light brownish, barred with blackish ; crown blackish, with median line of buff; neck ochraceous, streaked behind, and plain white on throat; outer tail feathers light buff, tipped with white, \&c.; lower parts whitish buff, deeper in winter. Length, 13 inches ; tail, 4 inches ; bill, $1 \frac{1}{4}$ inches.

"Appears in May, but is not at all abundant until August, when considerable flocks are to be found, especially in red-clover fields. If undisturbed, a flock will remain about a single field for several weeks. They feed largely upon grasshoppers, and in September are frequently very fat. They are shy, and when flushed fly to a great height, and whistle continually while on the wing."

\section{TRYNGITES, Oab.}

T. subruflcollis, Vieill. (rufescens.) Buff-breasted Sandpiper.

Toes not webbed; upper parts grayish buff, varied with blackish; lower parts buff, speckled on breast with dusky; quills speckled with dusky on a white ground. Length, 8 inches; tail, $2 \frac{1}{4}$ inches.

"Comparatively rare. Strictly a sea-board species. Two or three, or more frequently a single specimen is seen. Appear to be more wary than sandpipers generally, and alighting only on. the smooth beach, are difficult to approach."

\section{ACTITIS, Boie.}

(Tringoides, Bonap.)

A. macularia, L. Spotted Sandpiper. Teeter-tiltup. Tip-up. Teetertail.

Lustrous drab above, varied with black in summer; pure white below, with round black spots in summer. Length, 8 inches; tail, 2 inches; bill, 1 inch.

"Arrives with $T$. solitarius, but is a more sociable and more abundant species. Frequents the river and creek shores until June 1st, when nidification commences, and they are then scattered over the uplands. In August, congregate also on the river shores, and have generally left by October 1st." 


\section{NUMENIUS, Briss.}

N. longirostris, Wils. Long-billed Curlew. Sickle-bill.

Pale cinnamon, varied above with blackish, dusky and gray. Length, 24 inches ; tail, 4 inches ; bill, 5 to 9 inches.

"Arrive in May, and are with us till late in September. They fly in flocks of about twenty, sometimes more, and usually have a 'Ieader ;' their whole appearance while on the wing not unlike the Canada goose. Single specimens have frequently been killed inland. One at Trenton, in 1859."

N. hudsorricus, Lath. Hudsonian Curlew. Jack Curlew.

Similar to preceding, but paler; secondaries and quills darker ; crown with a narrow, median light stripe, besides broad lateral stripes. Length, 18 inches ; tail, $3 \frac{1}{2}$ inches ; bill, $3 \frac{1}{2}$ inches.

"Arrive in May. Not as abundant as the preceding, and have not been found inland. Frequent mud-flats and go in small companies. Have generally all disappeared by August 15th."

N. borealie, Forst. Esquimaux Curlew. Dough Bird.

Crown narrowly streaked and without median light stripe; plumage more reddish; breast with $\mathrm{V}$-shaped marks of dusky. Length, 14 inches; tail, 3 inches; bill, $2 \frac{1}{2}$ inches. Breeds in Northern North America; in winter, migrates as far as southern end of South America.

"Not very abundant. Makes its appearance very late in the summer, and is seen as late as November 1st. Frequents meadows, and feeds largely upon grasshoppers."

\section{Family Charadrimde.}

Plovers.

\section{CHARADRIUS, L.}

C. dominicus, Müll. (virginicus-Abbott's Catalogue.) American Golden Plover. Frost Bird.

Bill soft and flexible, fitted for probing in mud; no hind toe; plumage dark and grayish above, profusely speckled, some of the spots bright yellow ; grayish below (black in breeding season, in 
female). Length, $11 \frac{1}{2}$ inches ; tail, 3 inches; bill, $1 \frac{1}{4}$ inches; tarsus, 2 inches.

"Is seen inland in May, in quite large flocks. They remain but a short while, however, and none are seen until August, when with their young, they are moderately abundant. They prefer high open lands, are very wild, and stay in flocks of twenty to fifty. If undisturbed will frequent the same field during their autumnal stay. A few are found on the river, with sandpipers."

O. squatarola, L. (Squatarola, Cuv.), (helvetica, L.) Black-bellied Plover. Ox-eye.

A rudimentary hind toe; most of lower parts black in summer, white in winter; under tail coverts, \&c., and forehead white; upper parts spotted with dusky and white in summer, grayish in winter. Length, $11 \frac{1}{2}$ inches; tail, 3 inches; bill, $1 \frac{1}{4}$ inches; tarsus, 2 inches.

"Arrives along the sea-board early in May, and remains but a short time, but in August they return from the North with their young, and are frequently abundant. They are mostly very wild, and usually found in company with other birds. A straggler is occasionally found high up our rivers."

\section{ÆAGIALITIS, Boie.}

丑. vocifera, L. Killdeer. Plover.

Bill black, rather long; three toes with basal web; plumage brown ; rump orange brown; tail with black, white and orange; two black bars across breast and one above white forehead; black collar around neck; white collar around back-neck. Length, $9 \frac{1}{2}$ inches ; tail, $3 \frac{1}{2}$ inches.

"Arrives early in March, appearing to accompany the 'snipe.' Frequents meadows and river shore till May, when, after pairing, they go upon the upland, and build or rather scratch a nest, on the ground, in fields. Are sociable, noisy and strictly inoffensive. In August, again frequent the meadows and river shore."

必. wilsonia, Ord. Wilson's Plover.

Tail not projecting much, if any, beyond folded wings; rump same color as back, brownish gray; only one band across chest (black in male, brownish in female); forehead and lower parts white. 
"Common on the coast, but less seldom seen along our rivers than the following two species. Accompany other birds, and during the summer are generally seen by twos and threes. More gregarious as the season advances. During violent northeast storms are sometimes driven up the rivers, but make as short a stay as practicable. Author found them on the beach, off Barnegat, as late as November 12 th, in 1862 . They were in company with 'sanderlings' and 'red-backed sandpipers.'" - [C. C. A.]

Æ丹. semipalmata, Bonap. King Plover. Semipalmated Plover. Ringneck Plover.

Bill black tipped, short and stout; feet webbed at base ; plumage dark ashy brown, with forehead, hind-neck ring and lower. parts white; a broad band across breast, black in summer and grayish brown in winter; lighter in female. Length, 7 inches.

"In May, in company with Actodromas bonapartei (Tringa fuscicollis), this beautiful bird frequents the Delaware and Raritan Rivers, and although found throughout the summer, is less abundant in June and July than in May, and more plentiful in August than at any other time. They breed within State limits, but author has found no nests as yet. Seldom are seen far from running water, and generally in company with other birds."

丑. meloda, Ord. Piping Plover.

Toes slightly webbed, or web absent between middle and inner toes; upper parts brownish gray; white below, and on forehead and hind-neck collar; black patch on each side of chest; in female and in winter male this patçh duller. Length, $6 \frac{3}{4}$ inches.

"Arrives on the coast in May, but do not appear to remain for any length of time, although some breed in the immediate neighborhood of the ocean. About the middle of May, they appear on the Delaware in large flocks, but are very uncertain in their movements, being one day as abundant as the following they are scarce. In August, both inland and on the coast, they are more abundant. Are generally very numerous about New Brunswick, on the Raritan, in August." 


\section{Family APHRIzIDz.}

\section{Surf Birds.}

\section{ARENARIA, Briss.}

(Strepsilas. Morinella.)

A. interpres, L. Turnstone.

Toes four, not webbed; tarsus scutellate in front, and as long as the sharp-pointed bill; chest deep black; head and throat mostly white, upper parts dusky varied with rufous; tail coverts, wing coverts, \&c., white. Length, $8 \frac{1}{2}$ inches ; tail, $2 \frac{1}{2}$ inches.

"Arrives along our sea-coast in May, and passes on generally to the North, to return again in August, and then remains till October. It probably remains with us during the summer, in small numbers, as twice following violent storms, in the last week of June, in company with certain other strictly marine species, they have been shot at Trenton, on the Delaware. When birds are thus weather-driven so far from the ocean, it is probable they fly across the State to reach it again, thus accounting for their being seen inland."

\section{Family HzMATOPODIDAE.}

\section{Oyster-oatchers.}

\section{H出MATOPUS, L.}

H. palliatus, Temm. American Oyster-catcher.

Legs short, stout and bright colored; three toes, which are webbed at base ; bill red, woodpecker-like; tarsus reticulate and shorter than bill; upper parts blackish; white beneath; rump, \&c., dusky; tail coverts white. Length, 18 inches; tail, $4 \frac{1}{2}$ inches; bill, 3 inches.

"Frequents the sandy beaches of the State, and is never seen inland. About June 1st deposits its eggs in a little basin, hollowed out in the sand; but one brood only is raised. They feed on the small crustacea. Two or three are generally seen together, but they are nowhere nor at any time abundant in the State." 


\section{Sub-Order GRALLe-PALUdicole.}

\section{Family RALIIDZE.}

Rails.

RALLUS, L.

R. elegans, Aud. King Rail. Fresh-water Marsh Hen.

Wings and tail short; hind toe elevated; front toes long; forehead feathered; bill decurved, longer than head; brownish black above; chestnut below and on wing coverts; white bars on flanks. Length, 18 inches; middle toe, $2 \frac{1}{4}$ inches. Frequents fresh-water marshes.

"Arrives in May, and is abundant in meadows skirting our rivers. They build a nest of grass, in the grass, raising but the one brood. In July the young are strong upon the wing. They are very swift of foot, and run long when pursued by dogs: Have generally disappeared by October 1st."

R. longirostris, var. crepitans, Gmel. [Mud Hen. See Fulica americana.] Salt-water Marsh Hen. Clapper Rail.

Above olive brown, variegated with ashy; breast cinnamon buff, ashy tinged; flanks grayish brown, with white bars. Length, 15 inches; tail, $2 \frac{1}{4}$ inches; bill, $2 \frac{1}{2}$ inches; female smaller.

"Very numerous on the marsh meadows of the sea-board, where they arrive early in spring. They build in the long grass of the islands studding the bays, and raise two broods usually. Their eggs are an article of diet on the shore, being numerous and easily gathered."

R. virginianus, L. Virginia Rail.

Above olive brown, striped with black; wing coverts reddish ; breast cinnamon; flanks dusky, barred with white; lower parts mixed with black in immature specimens. Length, 10 inches; tail, $1 \frac{1}{2}$ inches; bill, $1 \frac{1}{2}$ inches. Like $R$. elegans, but smaller.

"Not an abundant species. Arrive in May, and nidificate as in the case of $R$. elegans. In August and September they are generally found in company with the 'sora' on the river flats. Occasionally every eighth or tenth bird will be this species, but 
it is seldom they are thus abundant. Have been known to remain during the winter, but this is probably an exceptional case."

\section{PORZANA, Vieill.}

P. carolina, L. Rail. Sor\%. Ortolan.

Bill straight, shorter than head; flanks barred with white and slate; neck to breast leaden, without spots; throat, \&c., black; top of head olive brown, with median black stripe; back streaked; belly barred. Length, 9 inches; tail, 2 inches.

"Much tendency appears to exist among people generally to enshroud this common bird with mystery, when in reality there is nothing very strange about it. Very many make their appearance along the Delaware early in May, and remain quietly in the meadows (unlooked for, and therefore unnoticed) until August, when they go in large numbers to the reeds on the flats, and remain there till the appearance of several severe frosts. It is not true that they suddenly and wholly disappear on the first appearance of frost. The ' rail' is a bird of very strong powers of flight, and migrates, flying for a great distance without requiring rest. As we have stated, many appear early in May, and these breed, building a nest of grass, in long grass, raising two broods. In August they congregate along water-courses, and the number annually hatched in May and June along the Delaware meadows is fully sufficient to explain the origin of the incredible numbers usually killed on the Delaware in September. Being a bird also of great locomotive powers, it is not improbable that the sudden accession to their numbers which has been noticed, should simply be a 'batch' from a neighboring river."

P. jamaicencis, Gmel. Little Black Rail.

Head and lower parts dark slate; belly brownish black, barred with white; back dark brown, speckled with white. Length, $5 \frac{1}{2}$ inches.

"Its habits are very similar to the 'sora,' and is about as abundant as the 'yellow rail.' Have not found it breeding in the State, although it very probably does so."

P. noveboracencis, Gmel. Yellow Rail.

Head and breast, inclusive, ochraceous; flanks dusky, barred with white; under tail coverts cinnamon; secondaries white; 
upper parts ochraceous, broadly striped with black and narrowly barred with white. Length, 7 inches.

"Rare. A few of these birds are generally killed during the ' rail season,' but when compared with the numbers of 'soras,' are emphatically rare. Have not found any breeding, or noticed them, except on the river, and during September."

\section{CREX, Bechs.}

c. crex, L. Corn Crake.

Above light brown, black striped; wings rusty, with a few white spots; head ashy, crown brownish; white below; chest drab; brown and white bars on sides and under tail coverts. Length, 10 irches. A North European form, accidental on this side of the Atlantic.

\section{IONORNIS, Reich.}

I. martinica, L. Purple Gallinule.

Forehead covered with a horny frontal plate; toes not lobed; nostril nearly circular; tarsus more than two inches long; plumage olive green above and purplish blue below and on head; bill reddish; under tail coverts white. Length, 12 inches; tail, 3 inches.

"Has been more frequently noticed than G. gateata, though like it, must be looked upon as a rare visitor only. Specimens have been taken about Tuckerton, on the Hackensack, near Newark, and on the meadows of the Delaware at Trenton. The author has met with five specimens in all, from the three mentioned localities, during the past seven summers. The latest specimen observed was killed on the $2 \mathrm{~d}$ of November, 1864, near Trenton."-[C. C. A.]

\section{GALLINULA, Briss.}

G. galeata, Licht. Florida Gallinule.

Nostrils linear ; frontal plate, bill and a ring around tibia, red ; tarsus little more than two inches; grayish black on head and below ; above brownish olive; white stripes on flanks; in winter, belly suffused with white. Length, 14 inches; tail, $3 \frac{1}{2}$ inches. A southern form, straying north. 
"Single specimens have occasionally been met with. Author has seen but one, which was killed in July, 1862, on the meadows skirting the Delaware, below Trenton. It was seen wading in a shallow ditch, as though fishing."-[C. C. A.]

FULIOA. L.

F. americana, Gmel. American Coot. Mud Hen.

Toes lobate, edged with broad flaps; bill white, tinged blue at end and there bearing a brown spot; frontal shield brown; sooty above; belly slaty; in winter, belly suffused with white. Length, 14 inches; tail, 2 inches. Frequents reedy marshes and shores.

"Generally are first seen about the middle of April, swimming leisurely about ponds and çreeks. Are not common on the rivers. When disturbed, they usually make but short flights, and not unfrequently endeavor to escape notice by creeping upon the shore or among bushes skirting the water's edge. They breed in the State, but the author has found no nest as yet. They feed largely upon small fish and aquatic insects, and are totally unfit for food. They have generally all disappeared by October, although single specinens have been met with in midwinter." [C. C. A.]

\section{Sub-Order herodiones.}

Herons, \&c.

\section{Family IBID}

(Tantalidm.)

Ibises.

\section{GUARA, Reich.}

G. alba, L. White Ibis.

(Fudocimus, Wagl.)

Groove in side of upper mandible; bill slender, cylindrical and bent downwards; head naked in front, crown with short feathers; plumage pure white; tips of longer quills greenish black; young grayish brown above, white below. Length, 25 
inches; tarsus, 3 to 4 inches; bill, 7 inches; tail, 4 inches. Belongs to Tropical America; casual as far north as Connecticut.

\section{PLEGADIS, Kaup.}

P. autumnalis, Hass. (falcinellus, L.), (Ibis ordii-Abbott's (atalogue.) Glossy Ibis.

Head feathered, crown feathers lanceolate, and forming a crest when erected; tarsus scutellate; bill curved as above; feet long; claws nearly straight; plumage rich chestnut, with metallic tints. Length, 24 inches; tail, 4 inches ; bill, $4 \frac{1}{2}$ inches. Southern.

"Stragglers only of this species are seen in New Jersey, and none ever breed bere. When seen it is generally near the coast, although occasionally they follow the course of our rivers. Author has seen a specimen killed on the Hackensack River, and saw a second on the meadows skirting the Delaware, a few miles above Bordentown, in Mercer county."-[C. C. A.]

\section{Family CICONIIDA.}

\section{Storks and Wood Mises.}

TANTALUS, L.

T. loculator, L. Wood Ibis.

Tarsus reticulate; bill stout, curved upwards ; toes long ; top of head covered by a smooth plate; plumage white; quills and coverts black; naked part of head bluish. Length, 40 inches; bill, 9 inches ; tarsus, 8 inches ; middle toe, 4 inches. Southern; casual as far north as New York.

\section{Family ARDEID az.}

Herons.

BOTAURUS, Steph.

B. lentiginosus, Montag. American Bittern. Indian Hen. Stake Driver.

Hind toe at same level as front ones; claws long, narrow, curved, and middle one pectinated; bill narrow and pointed; 
tail feathers ten, short and not very stiff; outer toe shorter than inner one; color ochraceous, mottled with brown and black above; quills slate, tipped with cinnamon; lower parts buff, striped with brown; dark spot on sides of neck. Length, 23 to 34 inches; tail, $4 \frac{1}{2}$ inches; bill, 3 inches; tarsus, $3 \frac{1}{2}$ inches; middle toe, $3 \frac{1}{2}$ inches.

"Very numerous. Appear in March, and are not unfrequently seen as late as November. They are most abundant on the edges of dense swamps, and when frightened take refuge by flying a short distance over-and then dropping into them. Are largely nocturnal in their habits, and about sundown make their neighborhood hideous with their coarse, peculiar croak. Do not frequent the river shores to any extent. Are abundant in the neighborhood of the ocean. Breed in swamps, raising one brood only. Feed largely upon frogs, and have been seen turning over stones in the bottom of brooks, evidently in search of salamanders. Are known as 'stake drivers' in some localities. Strictly inoffensive."

\section{B. exilis, Gmel. (Ardetta, Gr.) Least Bittern.}

Male glossy greenish black above, brownish yellow below; sides of neck and shoulders with chestnut; female with purplish

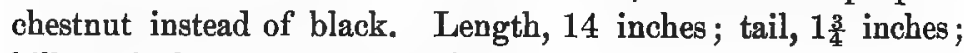
bill, $1 \frac{3}{4}$ inches; tarsus, $1 \frac{3}{4}$ inches.

"This beautiful little bird is more sensitive to cold weather, and seldom is seen before May 1st. It frequents meadows, and is generally found walking about in grass much taller than itself. It is rather shy, but when flushed, flies but a short distance. Does not take readily to trees. Although more abundant in the southern and central portions of the State, is generally to be found wherever one may look if it be marshy, open ground. They feed largely upon insects and the small fish that wander from the creeks into the ditches that drain meadow lands. Strictly inoffensive."

\section{ARDEA, L.}

A. herodias, L. Great Blue Heron.

Tail feathers twelve, stiff; feet black; outer toe not shorter than inner one; claws short and much curved; bill long and narrow; tibia chestnut brown, bare for two or more inches; 
color grayish blue; dusky below and black on sides of head; white on crown and white stripes below; back of head crested in

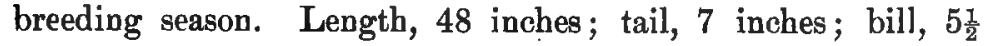
inches; tarsus, $6 \frac{1}{2}$ inches; female much smaller.

"Are first seen in April, but never appear to be as numerous as in August and September. They are equally abundant throughout the State, unless it be in the northernmost counties. Breed in swamps, but few in number, in the central portion of the State, and more frequently in Cape May county. During early spring and nidification remain inland the greater part of the time, but congregate about rivers and larger creeks in August. They feed on fish and reptilia, and are strictly inoffensive. The three lastmentioned species were formerly very abundant."

A. egretta, Gmel. (Herodias, Gr.) American Egret. White Heron. Great White Egret.

Pure white; head without lengthened feathers; a long train on back in breeding season. Length, 40 inches; bill, 5 inches; tarsus, 6 inches.

"Arrive a little earlier generally than the preceding, and are at all times more common, but never abundant. Frequeut meadow lands and the skirts of swamps rather than the river shore, and are less shy. Build in trees, at considerable elevation, but

- so slightly is the nest put together that the young generally destroy it when but a few days old, and are compelled to sit upon branches, if they have been lucky enough not to have fallen to the ground. Their food is fish and frogs principally. Strictly inoffensive. This and the above species are semi-nocturnal in their habits."

A. coerulea, L. (Florida, Bd.) Little Blue Heron.

Legs blackish or bluish; plumage slaty blue; young white; no dorsal plumes, but head with elongated feathers. Length, 24 inches; bill, 3 inches; tarsus, 4 inches.

" Occasionally are found as early as March 15th, if the weather be at all moderate. Vary very greatly in a series of years as to their abundance in the State. During the summer of 1860 they were very abundant along the Delaware, as high up as Belvidere, and very many bred along Crosswicks and Watson's Creeks, tributaries of the Delaware, in Mercer county. They were quarrelsome with allied species, and drove off the night-herons, 
generally so abundant. In their habits they are similar to the preceding species, but spend less time upon the wing, and become apparently more attached to a circumscribed neighborhood for the season. Occasionally specimens are found throughout the winter. Feed on fish generally, but go 'snail-hunting' frequently."

A. candiseima, Gmel. (Garzetta, Bonap.) Little White Egret. Snowy Egret. Snowy Heron.

Legs black and yellow; plumage pure white at all times; head and neck with long plumes in the breeding season. Length, 24 inches; tail, 4 inches; bill, 3 inches.

"Arrives about the 20th of April, if the weather is moderate, and is equally numerous throughout the State, though nowhere at all abundant. Annually two or three pairs visit the Delaware, about Trenton, and sometimes alight on the gravel-beds of the river. They are thus seen at all parts of the State. They build in high trees, in secluded positions, raising but the one brood. Are extremely shy, and feeding almost always in open meadows; are difficult to approach. They associate with allied species, more particularly the $A$. herodias. Feed upon fish and frogs. Strictly inoffensive."

A. tricolor, var. ruflcollie, Gosse. Louisiana Heron.

Moderate crest on back of head; upper parts bluish slate; plumes maroon purplish; white streaks on fore-neck; train light drab ; lower parts white. Length, 23 to 28 inches; tarsus, 4 inches. Southern; occasional in New Jersey.

A. virescens, L. (Butorides, Bonap.). Green Heron.

Tibia bare, one inch or less; bill more than thrice the length of its height ; crown, back and wings lustrous dark green ; neck purplish cinnamon, crested; back with lengthened feathers. Length, 18 inches; bill, $2 \frac{1}{2}$ inches.

"The most abundant of all the Ardeidæ in New Jersey. Is generally known by either one or the other of the meaningless names of 'shite-poke' or 'fly-up-the-creek.' Arrives in. May, and remains with us till October. Equally abundant ' up hill and down dale,' and in the driest positions is occasionally found in numbers. Breeds generally in maples or birches that skirt some small stream, generally raising but the one brood. Feed on fish exclusively when haunting water, but on the uplands devour large quantities of insects. Strictly inoffensive." 


\section{NYOTICORAX, Steph.}

N. [grisea; L.] nycticorax, var. nævius, Bodd. (Nyctiardæ gardeniAbbott's Catalogue.) Black-crowned Night Heron. Squawk, \&c.

Bluish gray; crown and shoulders glossy green; two or three long, white occipital plumes ; lower parts, \&c., white or yellowish; young light brown, speckled with white. Length, 24 inches ; bill, 3 inches; tarsus, 3 inches.

"A rrives in A pril, and seldom goes south before November, and it is not an unusual occurrence to find them in midwinter. At such times they frequent spring-holes, but what they there find to subsist upon deponent saith not. During the daybeing strictly nocturnal-they remain in the swamps and woodlands, and fly to their feeding-grounds after the sun is fairly down. They feed exclusively upon fish, unless it be in winter. From their note, which is a coarse, guttural sound, they have received the name of 'qua' or 'quok,' or from some the equally meaningleśs 'qua-bird.' They build among large trees, at less elevation than herons generally choose, raising but a single brood. Strictly inoffensive."

\section{Section NATATORES.}

Swimmers.

\section{Order lamellirostres.}

\section{Sub-Order ANSERES.}

Ducks, \&c.

\section{Family ANATID 2ב.}

Ducks.

MERGANSER, Briss.

M. americanus, Cass. (Mergus merganser, L.) American Merganser. Goosander. Fish Duck. Shelldrake.

Bill narrow, not black, with fine teeth along edge of mandibles, and at front, pointing backwards; head greenish black, bearing 
a crest; lower parts creamy white or salmon; rump and tail ash gray; back pied black and white; in female, head is cinnamon; upper throat white; upper parts grayish, with white on wings, and lower parts buffy white; both sexes have a black bar across the white of wings. Length, 26 inches; tarsus, 2 inches; middle toe, $2 \frac{1}{2}$ inches; culmen, 2 inches ; female smaller.

"Arrives early in October, flying in very large flocks for a few weeks, then, splitting up into small companies, disperse through the bays. Found frequently associated with other ducks, especially 'broad-bills.' Occasionally met with on the Delaware, about Trenton."

M. serrator, L. Red-breasted Merganser. Pied Shelldrake. Fish Duck.

Similar to preceding, but smaller and more crested; male with throat reddish brown, black streaked; wing with two black bars; nostrils near base of bill. Length, 20 inches.

"Not as abundant as the preceding, but more frequently met with on the Delaware, especially in April, when the meadows are overflowed. None seen during summer."

\section{LOPHODYTES, Reich.}

L. cucullatus, L. Hooded Merganser. Shelldrake. Crested Diver.

Serrations of mandibles short and blunt; bill black; crest white; head and upper parts black; white below; cinnamon, waved with black, on sides; in female, crest reddish; upper parts grayish brown; belly and upper throat white.

"Not abundant. Are more frequently met with along our river-courses than either of the two preceding species. It is generally known inland as 'pond sawbill.' Occasionally it probably breeds within State limits."

\section{ANAS, L.}

A. boschas, L. Mallard, or Mallard Duck. Tame Duck.

Bill flattened, distinct lamellæ in lower mandible; hind toe not bordered by membrane: in male, head and upper neck glossy green, a white ring below; breast purplish chestnut; wing coverts tipped with black and white; female dull ochraceous, streaked with dark brown. Length, 24 inches; tarsus 
$1 \frac{1}{2}$ inches, less than middle toe. The original of our domestic varieties.

"Common, making its first appearance in April and remaining in small numbers during the summer. It has been found breeding in Mercer county. In September and October is more numerous than at other times of the year."

A. Obscura, Gmel. Bilack, or Dusky Duck.

Resembles female of mallard, but darker, and no decided white except under wings; sexes alike in plumage. Length, 23 inches.

"Abundant during the spring and summer, inland, and also abundant on the coast during autumn. Frequents ponds along 'the shore,' and inland is partial to birch and maple-grown meadows, when overflowed by spring freshets."

A. discors, L. (Querquedula, Steph.) Blue-winged Teal.

Male with head and neck blackish plumbeous, darkest on crown ; a white crescent in front of eye; under parts pale chestnut, thickly spotted with black; female (and male in breeding season) dusky and buffy above; head, neck and lower parts brownish white; head streaked; belly spotted, or, in younger birds, pure white. Length, 16 inches; tail, 3 inches. Known by blue on wings.

"Common. Equally abundant with $A$. crecca. Less wary, and often caught asleep. Occasionally breeds in the State. Associates but little with other ducks. Is most abundant in September, and prefers the open river to narrow creeks."

A. carolinensis, Gmel. (Nettion, Kaup.) Green-winged Teal.

Male with broad white bar on breast; head, \&c., reddish chestnut, with patch of metallic green behind eye; neck black above and waved with black and white below and on back; female, upper parts grayish, varied by buffy bars; head, neck and lower parts brownish white, speckled with dusky on head, \&c.; belly speckled or white in younger birds. Length, 15 inches; tail, $3 \frac{1}{2}$ inches.

"Common. A few breed in the State. Pass through the State in April, and return as early as September. Are a wild, shy bird; are difficult to approach, and seldom caught napping. Somewhat more abundant on the river than creeks." 
A. crecca, L. European (English) Teal.

Male similar to that of preceding, but no white bar on breast; black and white undulations on side, \&c., coarser, otherwise not distinguishable from the green-winged teal.

"Have seen a single specimen that was killed in the State. Taken on meadows of Delaware River, near Trenton, April 21st, 1861. Occasionally killed on the coast."-[C. C. A. $]$

A. strepera, L. (Chaulelasmus, Gr.) German Duck. Gadwall.

Speculum white; wing coverts chestnut and black ; male, head and neck whitish brown, speckled with black; white and black crescents on crop; slate, with white undulations, on back, \&c.; tail coverts black; bill blue black; iris brown; legs orange yellow and webs dusky; in breeding season the crown is rusty, rump and breast tinged with rusty and under parts more spotted; female brownish, varied with dusky above and white below; belly white; chestnut of wings nearly rudimentary. Length, 22 inches; female smaller.

"A species belonging to the Southwestern States, and but seldom met with. A few seen in autumn and spring abopt Egg Harbor, but not regularly. Known as 'gadwell.'"

A. penelope, L. (Mareca, Steph.) European Widgeon.

Winter male, crown, belly and tail coverts white; tail spot green and velvet; back and sides waved with black; head and neck reddish; male after breeding season, tail coverts ashy blue; back, \&c., dark ashy gray; head and neck pale rusty, barred with dusky; female, head and neck as in summer male; tail spot grayish; white on wings reduced ; upper parts dusky brown, variegated; tail coverts barred; lower parts white. Length, 22 inches; tail, 5 inches. Frequent in Alaska; occasional on our eastern coast.

"A rare bird in the State. Has been killed at Barnegat, but the author has met with none taken about the rivers. Appears to be more frequent on Long Island."-[C. C. A.]

A. americana, Gmel. (Mareca.) American Widgeon. Baldpate.

Male, head and neck white, flecked with black (except on crown); a bright green patch on sides of head; back grayish white and sides reddish, all waved with black; female, head and 
neck white, streaked with dusky; upper parts dusky grayish brown, barred with dull white. Length, 20 inches; tarsus, $1 \frac{1}{2}$ inches.

"Abundant in spring and again in autumn. Both a 'shore' and inland species. When seen inland, are usually accompanied by 'sprig-tails.' Are easily stooled by imitating their whistlelike call. A few breed in the State."

\section{BPATULA, Boie.}

S. clypeata, L. Shoveller. Spoon-bill Duck.

Bill much widened towards tip; male, head and neck dark bluish green; breast white; lower parts chestnut; under tail coverts greenish; wing coverts bluish; tail speculum green; bill black; iris yellow; feet orange red; female, wings as in male, rest of plumage grayish brown, varied with whitish; head and neck brownish white and streaked; lower parts spotted with dusky; bill brown and orange. Length, 19 inches; bill, 23 inches.

"Not abundant, single specimens generally being found with other ducks. Most abundant during May and October. Does not breed in the State. Is more frequently seen inland than along the sea-board."

\section{DAFILA, Steph.}

D. acuta, L. Sprig-tail. Pin-tail.

Male, head and neck brown; hind-neck black; back and sides waved with white and dusky; speculum green to purple; a cinnamon bar on grayish wing coverts; tail pointed. Length, 28 inches. In breeding season, much like female. Female, lower part of head dull white, streaked with dusky; lower parts chiefly white; upper parts grayish dusky, with irregular yellowish bars; neck whitish, streaked with black. Length, 22 inches; tail, 9 inches or less.

"During the spring, on their way to the breeding-grounds, and on their return in autumn, they scatter about the State inland and along the shore. They associate with other ducks, and seldom fly in large flocks of their own kind." 


\section{AIX, Boie.}

A. sponsa, L. Wood Duck. Summer Duck.

Hind toe not bordered by a membrane; head crested; tip of bill formed entirely of "nail ;" male, head green, purple and violet, with white lines and throat patch; upper parts velvet black, with metallic tints; chest chestnut, with white spots; bars on sides of breast; belly white; bill variously colored (in life). Length, 20 inches. Female, head gray, with greenish crown and crest, and white fegthers at base of bill and backwards; throat white; chest brown and spotted; upper parts grayish brown. Length, 18 inches; tail, 5 inches.

"Arrives early in April, and is abundant in certain localities during the summer. Prefers small, quiet streams, hedged in by large trees. Builds in trees, and sits much upon the branches. Occasionally met with during the winter, but such is seldom the case."

\section{ÁYTHYA, Boie.}

A. vallisneria, Wils. Canvas-back.

Bill as long as middle toe without claw, end flattened, tip slightly hooked. (Sub-genus Aristonetta, Bd.) Male, head blackish on top and reddish brown below, with neck, chest, upper back and tail coverts with lower rump, black; rest of plumage, except quills, whitish, with dusky vermiculations; female, head, neck, chest and upper back brownish ; fore-neck, \&c., whitish. Length, 22 inches; bill, $2 \frac{1}{2}$ inches or more, its width one-third length.

"Not abundant, although annually killed, not only on the sea-board but occasionally on the Delaware River, as high up as Trenton. Have been killed on meadows during freshets."

A. americana, Eyt. (ferina, L.) Red-head. Pochard.

Male, head and upper neck chestnut, glossed with purple; belly white; rest of plumage black, except back, shoulders, sides and flanks, which are black and white (vermiculated); female, head and neck grayish brown, nearly white on throat; duller brown on back, chest and sides; bill shorter than head. Length, 20 inches.

"Arrives about the 1st of November, and is more or less common on the sea-board till March. Is less seldom seen inland 
than the 'broad-bill' or ' red-neck,' being taken on the Delaware regularly about Bordentown."

A. marila, var, nearctica, Stejn. (Fulix, Sund.) American Scaup Duck. [Broad-bill.] Blue Bill. Raft Duck. Big Scaup Duck.

Culmen as long as outer toe, with claw; bill wider (1 inch) at

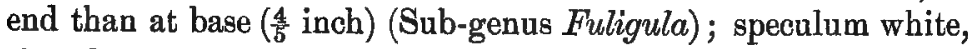
tipped with black. Male, bill, in life, grayish blue, with black nail; head, neck and chest black; wing coverts grizzled with grayish white. At end of breeding season more like female, but richer colors. Female white at base of bill, rest of head and neck snuff brown; belly white, graduating into the decided brown of sides; upper parts brownish dusky. Length, 20 inches.

"Abundant. Arrives along the sea-board about the 15th of October. Flies in large flocks, and is one of the most common species. Are occasionally met with on the Delaware as high up as Trenton."

A. affinis, Eyt. (Fulix, Sund.) Lesser Scaup Duck. Pond Broad-bill.

Similar to preceding, but smaller, with flanks vermiculated with blackish, and black of head of male glossed with purplish instead of green. Length, 16 inches; bill nearly 1 inch wide.

"Arrives about the 1st of October, and frequents small creeks rather than the bay, and is more frequently met with inland than the preceding. Seldom seen in summer."

A. collaris, Donov. (Fulix, Sund.) Ring-necked Duck, Red-neck.

Speeulum bluish gray. Male black, with violet gloss on head, a chestnut collar, and with white spot on chin ; bill transversely banded; female no collar; upper parts brown, shading into white of throat, chest and belly. Length, 18 inches.

"Arrives in October. Goes in small flocks. Is much more abundant during some seasons than others. Is very scarce generally in the spring. Occasionally seen inland, keeping on the rivers. Associates but little with other ducks."

\section{GLAUCIONETTA, Stejn,}

G. clangula, var. americana, Bonap. (Clangula, Flem., Bucephala-Abbott's Catalogue.) American Golden-eye. Garrot. Whistler.

Male, head and upper neck greenish black, with white spot on lores; white wing patch uninterrupted by black bars; lower 
parts white; upper parts pied; female, head brown; white collar of neck broader; chest grayish; wings dusky. Length, $16 \frac{1}{2}$ inches. Length of male, $18 \frac{1}{2}$ to 23 inches.

"Not very abundant. Generally found on the sea-board from November to March, and inland. Many were formerly killed on the Delaware, above Bordentown."

\section{CHARIONETTA, Stejn.}

C. albeola, L. (Clangula, Bucephala.) Buffle-head. Dipper. Butterball. Spirit Duck.

Male, head, \&c., rich dark green, bronze and violet purple, with large white patch behind eyes; back black ; nearly all the rest of plumage white; female, head and upper parts grayish brown; belly white, graduating into gray, on sides, front and posteriorly; inner secondaries, ear coverts, \&c., white. Length, 13 inches. Length of male, 15 inches.

"Common. More abundant on the sea-board than inland, although one of the more common of the river ducks. Occasionally met with during the summer."

\section{CLANGULA, Leach.}

C. hyemalis, L. (Harelda, Leach,) (glacialis-Abbott's Catalogue.) Old Squaw. Old-wife. Long-tailed Duck. South-southerly. Male, in winter, lower parts white, grayish on sides; upper parts and breast black; -upper back and chest, head and neck, white; sides of head and neck grayish and dusky; in summer, forehead pale gray; behind eyes white; head, neck and upper parts sooty brown or blackish, shading into the white of lower parts; female, in winter, head, neck and lower parts white; top of head dusky; chest grayish; upper parts dusky brown; in summer, head and neck dark grayish brown; white space on sides of neck and around eyes. Length, $15 \frac{1}{2}$ inches; of male, 22 inches; middle tail feathers, 8 inches.

"Common, though more abundant during some seasons than others. Is properly a marine species, but is occasionally seen inland. Following a very violent northeast storm in February, a large flock appeared on the Delaware, near Trenton, and fully one hundred were killed. This was in 1860 , and they have not been seen since in the same locality" (1867). - [C. C. A.] 


\section{HISTRIONIOUS, Less.}

H. histrionicus, L. (torquatus-Abbott's Catalogue.) Harlequin Duck.

Male, in winter, speculum dark violet blue; plumage in general bluish, much varied with white; sides bright rufous; in summer, much duller; speculum, under tail coverts, sides, \&c., grayish brown; female like summer male, but head, neck and chest grayish brown, with some white on head. Length, 17 inches.

"Very rare, and seen only on the sea-board. Young birds appear to be met with only. Is a northern species. Know of but two specimens, both killed off Tuckerton."-[C. C. A.]

\section{oAMTOLAIMUS, Gray.}

C. labradorius, Gmel. Labrador Duck. Sand-shoal Duck.

Male black, with head, neck, chest, scapulars and wings (except quills) white; female brownish gray. Liength, 22 inches. Now (1889) practically extinct.

"Not abundant. Arrives in October, and in small flocks is found along our sea-board generally. Leaves in April" (1867). - [C. C. A. $]$

\section{SOMATERIA, Leach.}

S. dresseri, Sharpe (mollissima, L.) American Eider Duck.

Male, in breeding plumage, white, with under parts, rump, quills and crown, black, bordered by pale green on head; female reddish brown, streaked and barred; bill with long, club-shaped frontal processes. Length, 24 inches.

"Rare. Appears in November, and straggling single birds occasionally shot during the winter, especially about Barnegat." [C. C. A.]

S. spectabilis; L. King Eider.

Male chiefly black; top of head bluish gray; front parts white, with a V-shaped black mark on throat; frontal processes broad and out of line with culmen; female brownish streaked and barred, as in other species of Somateria, but with the feathering on forehead reaching to the nostril. Length a little smaller than preceding. Its southern range in winter is marked by our northern boundaries. 


\section{OIDEMIA, Flem.}

O. americana, Sw. \& Rich. [Surf Scoter.] American Black Scoter.

Male black; basal part of bill yellowish; female grayish brown, paler below and on throat; bill all black. Length, 20 inches.

"Called 'coot' and sometimes 'butter-bill.' Passes its time at sea. This and the above arrive about November 1st, and remain till April."

O. deglandi, Bonap. (Melanetta velvetina-Abbott's Catalogue, O. fusca (L.), Sw.) White-winged Scoter, or Coot. [White-wringed Surf Duck. Velvet Scoter (?)]

$O$. deglandi and O. fusca are separate species, according to Ridgway, the latter being the velvet scoter, a European species accidental in Greenland. The two species seem to have been confounded by some previous writers. Our species has a much narrower space between the nostrils and the loral feathering. The male has the swollen lateral base of upper mandible unfeathered, and sides of bill more reddish yellow. The plumage is much as in the European form, black or brownish black, with a white spot on wings and back of eyes; female is sooty brown or grayish, darkest above and with no white on head. Length, - 22 inches.

"Arrives off our coast about the middle of October, and remains until the middle of April. Stays outside the beach always, and spends much of its time swimming."

O. perspicillata, L. (Pelionetta.) Surf Scoter. Surf Duck. Sea Coot.

Forehead feathering extends further forward than the loral feathering; the sides of bill at base have a naked swollen portion; no white on wing; male black, with red bill, black on swollen portions of base; a white spot on hind-neck, or on forehead. Length, 21 inches. Female, bill dusky, hardly swollen at base; upper parts dusky; lower parts grayish brown. Length, $18 \frac{1}{2}$ inches.

"The 'coot' is, like the above, an ocean-haunting species, and' is never found in the bays except when driven in by the storms." 


\section{ERISMATURA, Bonap.}

F. rubida, Wils. Ruddy Duck.

Male, top of head black; lower parts whitish (brownish gray beneath surface); upper parts reddish chestnut; female and young male, above grayish brown, mottled with buff; top of head darker; rest of head grayish white, with brownish stripe - on sides. Length, 16 inches or less.

"More abundant during some years than others. Not unfrequent in Chesapeake Bay, where it is known as 'salt-water teal."."

\section{NOMONYX, Ridg.}

N. dominicus, L. Masked Duck. Sun Domingo Duck.

Accidental in various parts of Eastern United States; differs from the above in having a larger nail at tip of bill, not bent back at tip, but nearly all visible from above; there is a white spot on wings, and young male and the female have two stripes on sides of head. Length, 14 inches or less.

\section{CHEN, Boie.}

C. hyperborea, var. nivalis, Forst. (Anser.) Greater Snow Goose.

Pure white (or washed with reddish grayish in young); quills black. Length, 30 to 38 inches. An arctic form, migrating south in winter. Bill, $2 \frac{1}{2}$ inches, robust, with prominent lamellæ.

"Rare. Two or three together occasionally met with along the coast in winter. Never seen inland, or on Delaware Bay."

\section{ANSER, Briss.}

A. albifrons, var. gambeli, Hartl. American White-fronted Goose. Speckle-bill. [Laughing Goose.]

Head grayish brown, forehead white; lower parts grayish white, spotted with black; tail coverts white; bill yellowish; feet light colored; back dark. Length, 27 to 30 inches.

"Like the preceding, is a rare species, met with only as a straggler, in winter. Have seen one specimen, killed at Barnegat."-[C. C. A.] 


\section{BRANTA, Scop.}

(Bernicla, Steph.)

Gerieric characters-Lores feathered ; feet, bill and neck black (with white patches); tail and quills black; tail coverts white; upper parts brownish; paler or grayish below.

B. canadensis, L. Canada Goose. Wild Goose.

Length, 35 to 43 inches; tail, $7 \frac{1}{2}$ inches. Lower parts light brownish gray; white throat patch extending on sides of head.

"Abundant during autumn and till spring. In March is not unfrequently met with inland, and has been known to alight and familiarize with the domestic geese. Do not breed in the State, except in a state of domestication. According to Smith's History, were much more abundant a century ago."

B. leucopsis, Bechst. Barnacle Goose.

Head nearly all white; chest (and back, sometimes) black; bluish gray above; grayish white below. Length, 26 inches. A European species accidental on our coasts.

B. bernicla, L. (brenta-Abbott's Catalogue.) Brant Goose.

Head all black; white streaks on sides of neck; upper parts brownish gray; grayish below, abruptly changing to black on chest.

"Abundant, from autumn till spring, along the coast. Are killed by thousands about Egg Harbor, during the shooting season. Vary, during a course of years, as to abundance."

B. nigricans, Lawr.

The black brant of Northwestern North America has been found accidently at Long Island. It has a white collar; indistinct in young; upper parts are sooty brown; lower parts slate. Length, 22 to 29 inches.

\section{OLOR, Wagl.}

(C)gnus, L.)

O. columbienus, Ord. (americanus, Sharpless.) Whistling Swan.

Tail twenty-feathered; bill with a yellow spot. Length, 50 inches.

"Swans appear along the coast during winter, entering the bays. Are killed every winter on the Delaware Bay, and on the 
Chesapeake especially. Never seen inland, unless it be a stray specimen 'flying over." "

O. buccinator, Rich. Trumpeter Swan.

Bill without yellow spot, longer than in above, and with nostrils nearer base. Length, 60 inches or more. Is rare on the Atlantic coast, and may scarcely be considered as belonging to a catalogue of the birds of New Jersey. It is mentioned here (as are other rare forms), as it might possibly be seen.

\section{Order STEGANOPODES.}

\section{Family SUIIDZ.}

\section{Gannots.}

SULA, Bries.

S. bassana, L. Gannet.

Hind toe connected by web with other toes, which are of unequal length; the lower jaw is feathered; legs, \&c., black ; color of plumage white, buffy on head; quills brown. Length, 30 to 40 inches.

"Are rare off the coast of New Jersey. Fly in quite large flocks, and frequent rocky sea-boards, resting upon the rocks when not fishing. Never seen in the bays."

\section{Family phatacrocoracidaz.}

\section{Cormorants.}

\section{PHALAOROOORAX, Briss.}

(Graculus-Abbott's Catalogue.)

P. carbo, L. Common Cormorant.

Bill strongly hooked; wings short (13 inches); tail large and stiff ( $7 \frac{1}{2}$ inches), of fourteen feathers; legs set far back; plu- 
mage lustrous black; back and wing coverts brownish ; in breeding season with crest and long white plumes on back of neck. Length, 34 to 40 inches. Colors of young paler, inclining to white.

"Appears off the coast during autumn, staying out at sea the greater part of the time. Is a much more common species than the following, though it varies as to its numbers very much during a course of years."

P. dilophus, Sw. \& Rich. Double-crested Cormorant.

Tail feathers twelve; wings and back slaty brown, otherwise greenish black; two curly black crests in adult; pouch bright orange. Length, 29 to 33 inches.

"Appears off the coast in November, and is seen very frequently during the winter. Fishes at sea, and after being well stuffed, comes to shore and sits on sandeliffs, awaiting the process of digestion."

\section{Family PELECANID}

\section{Pelicans.}

\section{PELEOANUS, L.}

P. erythrorhynohus, Gmel. (trachyrhynchus, Lath.) American White Pelican.

Large fish-eating birds, with long bills, ending in a hook; a large sac between the branches of lower jaw ; nostrils abortive; wings long; tail short; live in flocks; color white, with black on wings. In breeding season a yellowish crest, red bill and feet. In winter more yellowish. Length, 60 inches; bill, 12 - inches; weight about 17 pounds. Nest a rude mound of gravel and rubbish on some shore, usually inland.

"Is but seldom met with, though was probably a numerous species. Anthor saw three flying off Sandy Hook, in February, 1864, and has seen one mounted specimen said to have been killed near Tuckerton."-[C. C. A.] 


\section{Order LONGIPENNATI. (CECOMORPHE.)}

\section{Sub-Order TUbinares.}

\section{Family PROcellarimdze.}

\section{Petrels.}

FULMARUS, Leach.

F. glacialis, L. (Procellaria meridionalis-Abbott's Catalogue.) Fulmar.

Nasal tubes long proportionately and close together; bill short and stout, and dusky or brownish; head, neck and lower parts white; upper parts bluish gray, the quills darker, or whole plumage may be gray. Length, 19 inches.

"Met with, but not abundantly, during the spring and again in autumn, off the coast. At neither season do they make any prolonged stay. Occasionally, but very seldom, have been killed in the bays."

PUFFINUS, Briss.

P. puffinus, Brünn. (anglorum-Abbott's Catalogue.) Manx Shearwater.

Bill cylindrical; nostrils separated widely and visible from above; plumage sooty blackish; lower parts white; lower tail coverts white and dusky. Length, 14 inches; tail, 3 inches ; wing, 9 inches.

"Rare. Appears off the coast about the middle of November, and is seen occasionally until March. The author met with several off Sandy Hook in December, 1863."-[C. C. A.]

P. major, Faber. Greater Shearwater.

Throat white, abruptly separated from dusky of top and sides of head and neck; bill blackish; upper tail coverts white; belly clouded with gray. Length, 20 inches; wings, 13 inches. Inhabits the Atlantic Ocean generally. 
P. stricklandi, Ridg. Sooty Shearwater.

Lower parts dusky; bill brownish; under wing coverts gray, mottled with white at tips. Length, 16 inches; wings, 12 inches. Inhabits American side of North Atlantic.

P. auduboni, Finsch. Audubon's Shearwater.

No white tips to wing coverts; lower tail coverts dusky; above sooty black; white of under side head extends nearly to eye. Length, 11 inches; wings, 8 inches; tail, $3 \frac{1}{2}$ inches; tarsus, $1 \frac{1}{2}$ inches. Inhabits warmer parts of Atlantic; casual on coast of New Jersey.

\section{AFSTRELATA, Bonap.}

Af. hastata, Kuhl. Black-capped Petrel.

Cutting edge of lower mandible concave; upper parts dusky; upper tail coverts white; head and neck white; head blackish on top. Length, 15 inches; wings, 11 inches; tail, 5 inches. Inhabits Middle Atlantic and straggles occasionally to our coasts (Florida to Long Island).

OOEANODROMA, Reich.

O. leucorhoa, Vieill. Leach's Petrel.

Upper tail coverts white (or grayish), without black tips; plumage sooty, darker above; a grayish band across chest. Length, 8 inches; wings, 6 inches; tail, 4 inches, forked for nearly one inch. Feet black. Inhabits the oceans of northern bemisphere.

\section{OOFANITES, Keyser. \& Bl.}

O. oceanue, Kuhl (Thalassidroma wilsoni). Wilson's Petrel (incorrectly, the Stormy Petrel, $P$. pelagica, which does not range south of Banks of Newfoundland, on our side of Atlantic).

Secondaries ten; claws narrow and pointed; belly and flanks dusky; sooty black above; tail and quills black; upper tail coverts white; web of feet yellowish; tail not forked. Length, 7 inches; wings, 6 inches; tail, 3 inches.

"Not uncommon off the coast. Occasionally. during severe storms is driven across the State and up the Delaware and other rivers, but makes no longer stay inland than practicable. Does not breed in the State." 


\title{
Sub-Order LONGIPENNES.
}

General characters-Feet palmate; hind toe small and elevated; bill long; wings long and pointed.

\section{Family STERCORARIID王.}

\author{
Skuas and Jaegers. \\ STERCORARIUS, Briss.
}

B. pomarinus, Temm. (pomatorhinus.) Pomarine Jaeger.

Covering of upper mandible in three distinct pieces (a terminal hook, and basal cere of separate pieces); middle tail feathers project and are broad at ends; plumage in two phases; light phase, upper parts sooty; lower parts and front of head and neck white; dark phase, no white. Both phases grade into each other. Length, 20 inches; wings, 15 inches.

"When, as is the case during one winter in every ten, coast birds are unusually numerous, this among others may sometimes, but very rarely, be met with in midwinter."

S. parasiticus, L. Parasitic Jaeger. Arctic Jaeger.

General color dark brown, with two extremes as above; middle tail feathers pointed, project four inches. Length, 18 inches; wings, 13 inches.

"This species is little less abundant than the preceding, and like it, only met with during the winter."

S. longicaudus, Vieill. Long-tailed Jaeger.

With middle tail feathers projecting eight or ten inches; probably gets as far south as New Jersey, in winter, extremely rarely, although a very cold season favors an extension of its migration. 


\title{
Family LARID $\not \mathbf{~}$
}

\author{
Gulls and Terns.
}

RISSA, Leach.

R. tridactyla, L. Kittiwake Gull.

Legs and feet dark; hind toe rudimentary ; plumage in summer white, with black on quills and tip of tail ; in winter with hind-head and neck suffused with gray; mantle pearl gray; more dark patches in young. Length, 17 inches; wings, 12 inches.

"This gull is common off the coast from November to April, but is never seen inland or along the Delaware. Seldom observed in summer. Does not breed in the State."

\section{LARUS, L.}

L. marinus, L. Great Black-backed Gull. Coffin-carrier. Saddleback.

Hind toe perfect ; mantle dark slate; primaries black ; rest of plumage white, streaked with dusky on head in winter; young dusky above and head streaked. Length, 28 to 31 inches; wings, 18 inches; tarsus, 3 inches.

"The young of this species are those generally met with off the coast and in the rivers of this State. Does not ascend the Delaware above Philadelphia, and is there met with very rarely. None breed in the State."

L. glaucuø, Brünn. Glaucous Gull. Ice Gull. Burgomaster.

No black on wings; bill yellow, with red spot on lower mandible. Length, 30 inches. Its southern limit is Long Island.

L. leucopterus, Faber. Iceland Gull. Whitelwinged Gull.

Similar, but length 23 inches. Limits nearly the same as preceding.

L. argentatus, var. smithsonianus, Coues. American Herring Gull. Common Gull.

Feet flesh colored; mantle grayish blue or lighter; no black spots on bill ; red spot on lower mandible; young grayish; bill dark. Length, 22 to 27 inches; wings, 17 inches. 
"Off the coast from November 15th or thereabouts until March. Probably does not ascend the rivers any distance. Appears to prefer the open sea to the bays. Go north to breed in March. Are not as abundant at any time as the following species."

L. delawarensiø, Ord. Ring-billed Gull.

Plumage like preceding; feet olivaceous; webs yellow; bill yellowish, with black band at tip. Length, 20 inches; wings, 15 inches.

"Makes its first appearance about October 1st, and is abundant on our sea-board and along our rivers until April, when they have all left for their breeding-grounds. This gull is very abundant on the Delaware, as far up as Philadelphia, but seldom ascends farther."

L. atricilla, L. (Chroecocephalus, Eyt.) Black-headed, or Laughing Gull.

Bill and feet dusky carmine; tarsus longer than middle toe; lower parts white, roseate in breeding season; head sooty slate, white in winter; mantle leaden; five outer primaries black, rest of quills gray; young brownish and white. Length, 15 to 17 inches; wings, 13 inches; tail, 5 inches.

"Abundant, not only on the coast but in Delaware Bay. Seldom ascends farther up the river than Philadelphia. Breeds in Cape May county. Is first seen about April 1st, and generally have all disappeared by the middle of October."

L. philadelphia, Ord. Bonaparte's Gull.

Tarsus not longer than middle toe ( $1 \frac{1}{2}$ inches); bill deep black; plumage generaliy white; head dark gray in summer, white in winter; mantle pearl gray; quills white and pearl gray, tipped with black; feet orange red, paler in winter. Length, 13 inches; wings, 10 inches.

"This gull is abundant on our coast and along our rivers from April 1st, but does not make a prolonged stay, and never breeds within State limits. This species ascends the Delaware as far as Trenton more frequently than any other species. Are not seen during the winter." 


\section{XEMA, Leach.}

X. sabinii, Sab. Sabine's Gull. Forked-tail Gull.

Much 'like above, but with a black collar and hood; more black on quills; mantle deeper bluish gray; bill tipped with orange. Length, $13 \frac{1}{2}$ inches ; tail, $4 \frac{3}{4}$ inches, forked for nearly 1 inch. Ranges south to New York, casually further south.

\section{GELOCHELIDON, Brehn.}

G. nilotica, Hass. (anglica, Mont.,) (Sterna aranea-Abbott's Catalogue.) Marsh Tern. Gull-billed Tern.

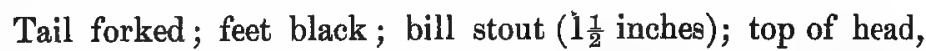
\&c., black in summer, white in winter; upper parts pearl gray, otherwise white. Length, 15 inches ; wings, 12 inches; tail, $5 \frac{1}{2}$ inches.

"Arrive about April 15th. Breed along the coast. Not found inland. Do not associate with other species."

\section{STERNA, L.}

S. tschegrava, Lepech. (Thalasseus caspius, Pall.) Caspian Tern.

Tail forked for less than a fifth of its length ; adult in spring, top of head glossy black; feet black; bill red; plumage white, pearl gray above; after pairing season, white, speckled on the black of head; winter adult white or grayish, streaked on head; dark colors more extended in young. Length, 20 inches; wings, 17 inches; tail, 6 inches.

"A northern species, only occasionally met with. Is more rarely seen than the sooty tern. Is met with in winter."

S. maxima, Bodd. (T. regins, Gamb.) Royal Tern.

Bill orange; tail forked for half its length; adult in spring, top of head and occipital crest and feet, black; after pairing season, only occipital region black ; in winter, white, mixed with black of occiput; bill paler; young like winter adult, but upper parts spotted. Length, 20 inches; wings; 15 inches; tail, 8 inches. More slender body than preceding.

"Like the preceding, is a rare species. Visits us from the South during the summer. Does not breed in the State." 
S. sandvicensis, var. acuflavidus, Cabot. Cabot's Tern.

Bill deep black, with whitish tip; otherwise much like preceding. Length, 15 inches; wings, $12 \frac{1}{2}$ inches; tail, 6 inches, forked for $2 \frac{1}{2}$ inches; bill, $2 \frac{1}{4}$ inches. A southern form ranging north on the Atlantic coast to Southern New England. Rare. Same as Thalasseus cantiacus, Sandwich Tern.

s. trudeaui, Aud. Trudeau's Tern.

Mantle bluish gray; no black on head, but a dusky stripe on each side; general color white and pearl gray; lower parts pure white in winter; bill yellowish, with black middle in summer,

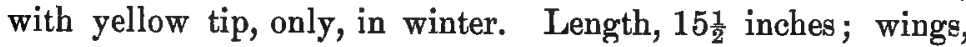
10 inches; tail, 5 inches or more, forked for about one-third of its length. Inhabits "Atlantic coast of South America; casual on Atlantic coast of United States (New Jersey)."-Ridgway.

"Met with rarely, in winter only, being a northern species." - [C. C. A.] Probably refers to the arctic tern.'

S. forsteri, Nutt: Forster's Tern.

Inner web of outer tail feather dusky towards end, outer web all white; in summer, above pearl gray; white below; top of head black; bill orange, with dusky tip; feet reddish orange; in winter, top of head white; sides of head striped; tail less forked; bill with more dusky; feet paler. Length, $14 \frac{1}{2}$ inches ; wings, 10 inches; tail, 5 to 8 inches, forked for $2 \frac{1}{2}$ to 5 inches.

"Occasionally met with during the winter, but rarely."

S. hirundo, L. (wilsoni, Lawr.) Wilson's Tern. Common Tern. Sea Swallow.

Inner web of outer tail feather all white; outer one dusky; summer plumage, lower parts grayish white; upper parts pearl gray; top of head black ; tail mostly white; bill red, blackening towards tip; feet rich orange vermilion; in winter, white encroaches on black of head from the front; lower parts pure white; bill and feet duller. Length, 13 to 16 inches; wings, 10 inches; tail, 5 to 7 inches, forked about half way.

"Appears off the coast April 15th. Called 'sheeps-head gull.' Breeds along 'the shore,' depositing its eggs on the drift-grass. Is found along the rivers Delaware, Raritan and Hackensack."

\section{S. paradisæa, Brünn. (macrura, Naum.) Arctic Tern.}

Bill carmine throughout; tail and tips of secondaries white, in sharp contrast with grayish cast of rest of plumage. Length, 
14 to 17 inches; wings, 10 inches ; tail, $6 \frac{1}{2}$ to $8 \frac{1}{2}$ inches, forked for 4 to 5 inches. Breeds south to Massachusetts.

S. dougalli, Montag. (paradisea-Abbott's Catalogue.) Roseate Tern.

Both webs of outer tail feathers all white; in summer, silvery gray above; pinkish below (fades to white in dried specimenw); top of head black; bill black, with red base; feet red (in life); in winter, less black on fore part of head.

"This species visits is during the summer, from the South. Is always a rare bird in New Jersey, but is more common during some summers than others."

S. fuliginosa, Gmel. (portlandica, Ridg.) Sooty Tern.

Mantle and middle tail feathers blackish, outer ones white; forehead, sides of head and lower parts white; upper parts, bill, and feet black; less white in young. Length, 15 to 17 inches; wings, 12 inches; tail, 7 inches, forked nearly half way. A tropical species.

"Rare. Is seldom seen at any time, and only during the summer, off the coast. Does not breed in the State."

S. antillarum, Less. (superciliaris, frenata.) Least Tern.

In summer, pearl gray above; white below, and a crescent on forehead; top of head and lateral stripes black; bill yellow, with dark tip ; feet orange yellow; in winter, yellows paler, and black of head gives way to white anteriorly. Length, 9 inches; wings, $6 \frac{1}{2}$ inches; tail, $3 \frac{1}{2}$ inches, forked half way.

"Arrive about middle of April. Breed, depositing eggs on the sand. Ascend our rivers. Disappear by October 1st."

\section{BYDROCHELIDON, Boie.}

H. nigra, var. surinamensis, Gmel. (plumbea.) American Black Tern. Toes not full webbed; head and lower parts all black in summer, white in winter ; upper parts leaden, more brown in young. Length, 10 inches; wings, 8 inches; tail, $3 \frac{1}{2}$ inches, forked less than 1 inch.

"Very abundant during the summer, not only about our seaboard, but inland. Are more numerous inland, about Raritan Bay, than in the Delaware. Breed in the salt meadows about 
Newark probably. Seldom ascend the Delaware very far, and bave never been seen by the author above Burlington, Burlington county."

\section{Family RYTCHOPID 2 .}

Skimmers.

\section{RHYNOHOP\$, L.}

R. nigra, L. Black Skimmer. Cutwater. Shearwater.

Lower mandible longer than upper, compressed like a knifeblade; tail white, with middle feathers dusky; secondaries tipped with white; in summer, forehead, sides of head and lower parts white; upper parts, \&c., black; base of bill, feet, \&c., red; in winter, black is more brownish, and there is a white collar across hind-neck; the young are buffy above. Length, 17 to 20 inches; wings, 15 inches ; tail, $5 \frac{1}{2}$ inches, forked about a fifth of length. Upper mandible nearly 3 inches; lower one, 3 to 4 inches.

"Arrives off the coast in May, and remains during the summer. Breed mostly in Cape May county. They come from the South in the spring, and return in August. Are very rarely seen on the rivers, even near the mouths, where the water is brackish. Never seen during the winter."

\section{Order PYGOPODES.}

\section{Divers.}

Legs set far back; feet webbed or lobed; position of bird when standing, nearly erect; hind toe small; wings small.

\section{Family PODICIPIDZ.}

\section{Grebes.}

COLYMBUS,, L.

(Podiceps, Latham.)

O. auritus, L. (P. cornutus, Gmel.) Horned Grebe.

Bill slender, black, tipped with yellow, shorter than head; breast brownish red; head black; general color dark brown; 
ochraceous crest of soft feathers on each side of occiput. Length, 14 inches; wings, 6 inches; bill, $3 \frac{3}{4}$ inches.

"About as frequently met with as the orested species; and as in that case, generally the young birds are met with. Ascends the rivers more than the 'red-necked' species."

C. cristatus, L. Crested Grebe.

Bill about as long as head; lower parts white, not mottled; nuptial plumage, throat and chin buffy white, becoming reddish on ruff; top of head and occipital crests black, rest of plumage dark brown; secondaries white. Length, 23 inches; wings, 7 inches; bill, 2 inches. "Nearly cosmopolitan, but no authentic records for any portion of America."-Ridgway. "Not American."-Jordan.

"Much less common than the red-necked grebe. Met with only in winter, and nearly all young birds. Has been found on the Raritan, above New Brunswick."-[C. C. A.] Possibly varieties or younger birds of $C$. auritus have been mistaken for cristatus.

C. holbœlii, Reinh. (P. griseigena-Abbott's Catalogue.) Red-necked Grebe. Holbœll's Grebe.

Lower parts mottled white or ash; nuptial plumage, top of head black, rest of head gray; neck brownish red; crests and ruffs not large. Length, 18 to 20 inches; wings, 8 inches; bill, 2 inches. Northern.

"This species is only a winter visitor, and is never abundantly met with. Is found about Delaware Bay, but seldom ' up the river." "

\section{PODIL YMBUS, Less.}

P. podiceps, L. Devil Diver. Pied-billed Grebe. Diedapper. Helldiver. Water-witch. Dab-chick, \&c.

Bill stout, hooked; no ruff or crest; brownish above, silvery ash below; nuptial plumage, chin, throat, cheek, black; rest of head brownish gray; spotted with dusky below; bill whitish, with dark band; in winter, black replaced by dull white; no spots below; bill brownish; no black band; sides of head striped with brown, in young. Length, 14 inches; wings, 5 inches; bill, 1 inch.

"Very common, and known under a legion of names, but 
devil diver is probably that most generally used. Arrives early in April, and is found in all our creeks, mill-ponds, \&c.-in nearly all water that contains small fish. Remains until the middle of October, and breeds within the State. Is by many erroneously considered the female of the 'coot,' Fulica americana."

\section{Family URINITORIDE.}

(Eudytidø.)

Loons.

\section{URINATOR, Cuv.}

(Fudytes, Illig.)

U. imber, Gunn. (immer, Brünn.,) (Colymbus torquatus-Abbott's Catalogue, glacialis, L.) Diver. Great Northern Loon.

Hind toe present, but small; no ruffs or naked spaces on head; can hardly walk, but good flyers; voice sharp and wild; plumage blackish above, whitish below ; in summer, upper parts spotted with white; throat, \&c., black, with white streaks on sides of neck; head, \&c., glossed with green ; in winter, and in young, white spots above absent; fore-neck white. Length, 36 inches or less; wings, 15 inches; tarsus, 3 inches; bill, 3 inches.

"Probably not a resident, as it has not been found breeding in the State, and is very seldom seen during the summer months. They are abundant on our sea-board and about our rivers from October till the middle of April. Seldom seen off our rivers when inland, unless compelled to take to flight, which they seldom do."

U. arcticus, L. Black-throated Diver, or Loon.

Similar to preceding, but, in summer, hind-neck grayish, foreneck black, with white streaks on sides between the black and the gray. Length, 28 inches ; wings, 13 inches; bill, $2 \frac{1}{2}$ inches. Northern boundary of United States marks its southern limit.

"Young specimens of this diver are very rarely taken, probably, on our sea-board. But only one such instance has come to the notice of the author. Is the rarest of rare visitors."

U. lumme, Gunn. (septentrionalis.) Red-throated Diver, or Loon.

Head and neck gray, streaked with white behind and chestnut on fore-neck in summer, white in winter; upper parts black- 


\section{GEOLOGICAL SURVEY OF NEW JERSEY.}

ish, with white spots; lower parts white. Length; 27 inches or less ; wings, 11 inches; bill, 2 inches.

"Young specimens of this rare bird have been occasionally taken, not only on the coast, but in Delaware Bay. Met with only during the depths of winter. Have seen but one adult specimen killed in the State."-[C. C. A.]

\section{Family ALCID a.}

Auks.

FRATEROULA, Briss.

F. arctica, L. Arctic Puffin.

No hind toe; deciduous basal shields on bill not white; horny processes on eyelids short; upper parts and neck band blackish; sides of head gray; whole throat grayish in breeding season; lower parts white. Length, 11 to 13 inches; bill, $1 \frac{3}{4}$ inches. Breed south as far as Bay of Fundy.

"Occurs off the coast in winter, and is seldom met with: This bird, like the razor-bill, remains wholly at sea, never being met within the outer beach."

\section{Ceppeus, Pal.}

C. mandtii, Licht. Mandt's Guillemot.

Greater wing coverts all white; rest of plumage black; in winter all except wings white, with black markings above. Length, 13 inches; wings, 7 inches; bill, 1 inch. An arctic form, breeding as far south as Labrador. Comes south as far as New Jersey in winter.

O. grylle, L. Black Guillemot.

Much like above, except that basal half of white wing coverts is black and bill is stouter. Breeds south to Maine.

"Much more frequently met with than the arctica and torda, and flies nearer the beach, but very seldom over it to the bay. Noticed only during winter." 
URIA, Briss.

U. troile, L. Murre. Foolish Guillemot.

Upper parts dusky; white below; secondaries tipped with white; bill compressed; upper mandible notched near tip; chin, throat, fore-neck and sides of head velvety brown in summer, white in winter, but sides of head not white in young; top of head and hind-neck smoky brown. Length, 15 to 18 inches; wings, 8 inches; bill, $1 \frac{3}{4}$ inches. Breeds from Nova Scotia northward.

"About as abundant as the preceding. Met with during autumn and winter, and seldom after the middle of March. Remains always at sea."

U. ringvia, Brünn. Murre.

Same as above, but white ring around eye connecting with a white streak behind eye. Perhaps not a distinct species.

"Rather more abundant than the preceding, appearing off the coast in November, and remaining until March. Like the preceding, remains at sea."

U. lomvia, L. Brünnich's Murre. Thick-billed Guillemot.

Top of head and hind-neck sooty black; basal portion of cutting edge of upper mandible light colored; sides of head, fore-neck, \&c., snuff brown in summer. Length, 14 to 18 inches; wings, 8 inches; bill, $1 \frac{1}{2}$ inches.

"Is probably not as common as the preceding, but is very generally to be met with during the winter. Have seen them quite abundant off Sandy Hook (December, 1863)." - [C. C. A.]

\section{ALOA, L.}

A. torda, L. Razor-billed Auk.

Bill deep, much compressed, and shorter than head; tail feathers pointed; wings strong; upper parts black ; tips of secondaries and lower parts white; in summer, head and neck (except on top) velvety snuff brown; white line (except in young) from bill to eye; bill crossed by white bar in middle, and with basal lamina; in winter, no lamina, no white line to eye, and snuff brown replaced by white. Length, 15 to 18 inches; wings, 8 
inches; tail, $3 \frac{1}{2}$ inches; bill, $1 \frac{1}{4}$ inches, nearly 1 inch deep. Breeds from Eastern Maine northward.

"Stragglers make their appearance off the coast in winter, but are rarely met, however. Like many allied birds, is more frequent during some seasons than others, and occasionally has been seen as early as October."

\section{ALLE, Link.}

A. alle, L. (Mergulus-Abbott's Catalogue.) Dovekie. Little Auk.

Bill short and broad; head, neck and upper parts black; secondaries tipped with white; white below; flanks and scapulars streaked; in summer the sides of head, neck, chest, \&c., are dark sooty brown; in winter white. Length, 7 to 9 inches; wings, $4 \frac{1}{2}$ inches ; bill, $\frac{1}{2}$ inch.

- "Known in some localities as 'sea-dove.' Appears off the coast about the middle of November, and is seen until the beginning of March. They sit out some distance from the beach, generally two or three at a time. Never are met with in the bays. None breed in the State."

The Great Auk, Plautus impennis, L. (length, 28 to 30 inches,) of coasts of North Atlantic south to Massachusetts Bay, has not been abundant since 1844 , and is now believed to be extinct. 


\section{CIAse REPTILIA.}

\section{Order Chelonia.}

(TESTUDINATA.)

\section{Family EMYDID}

Pond Turtles.

OISTUDO, Flem.

O. carolina, L. (virginea.) Common Box Turtle, or Tortoise.

Carapace very convex; plastron divided by transverse hinge into two or more movable pieces; toes hardly webbed; colors variable, chiefly blackish, variegated with yellow. Live in dry woods.

"A very abundant species, that should be encouraged in every garden in the State, as they wage an unending war against a multitude of noxious creatures. The habit of cutting initials upon the shell of this animal has resulted in proving it to be an animal of long life. Instances of this, showing the animal to have been from fifty to eighty years of age, have come under the notice of the writer."-[C. C. A.]

\section{CHELOPUS, Raf.}

C. muhlenbergii (Schw.), Cope (Calemys-Abbott's Catalogue). Muhlenberg's Tortoise. Water Turtle.

Carapace elongated, arched; plastron immovable; toes short, with small web; habits semi-aquatic; size small; no round spots on shell ; upper jaw deeply notched; orange spot on each side of neck; plastron black, with central yellow; carapace brown, with yellow markings. Length, $4 \frac{1}{2}$ inches.

"Equally abundant with $N$. guttatus, and generally found associated with it. They feed upon fish, and are inoffensive in every way." 
C. insculptus, Le C. (Glyptemys, Ag.) Wood Tortoise, or Terrapin.

Upper jaw broad at end; width of jaw less than forehead; tip of lower jaw curved up; shell marked with concentric striæ and radiating lines; a black patch on each plate of plastron. Length, 8 inches.

"This reptile does not appear to be an abundant species. It is less aquatic than the preceding species, and is generally met with in woodlands."

\section{NANEMYS, Ag.}

N. guttatus, Schn. Speckled Tortoise. Spotted Turtle.

Upper jaw slightly notched; shell not carinated; black, dotted with orange; plastron yellow, blotched with black. Length, $4 \frac{1}{2}$ inches.

"A very abundant species, inhabiting the creeks throughout the State, and occasionally met with in swampy land which has no running water."

\section{CHRYSEMYS, Gray.}

C. picta, Herm. Mud Turtle. Painted Turtle.

Carapace flattish; plastron broadly united at sides to carapace; toes broadly webbed; hind legs stouter than fore legs; upper jaw notched in front; head with yellow lines; red on neck, tail, legs, \&c.; large plates of carapace plain; marginal plates with red markings; greenish black above; yellow below. Length, 8 inches.

"This handsomely-marked species is not very abundant. About equally numerous in the various counties, except where salt water prevails."

\section{MALAOOOLEMMYS, Gray.}

M. geographicus, Le S. (Graptemys, Ag.) Map Turtle.

Upper jaw not notched; carapace keeled, notched behind; lower jaw with spoon-shaped dilatation; head with horny skin; plastron yellowish; color above dark olive brown, with greenish and yellowish reticulations, especially on edge of carapace, legs, neck, \&c.

"More common than $P$. rugosa, and more generally distri- 
buted throughouit the State. The creeks of the central counties generally contain them, associated with the more common species."

M. palustris, Gmel. Terrapin. Salt-marsh Turtle. Diamond-back.

Sheath of jaws straight; concentric dark stripes on plates of both carapace and plastron; color greenish to dark olive.

"The eagerness with which this species is sought, in consequence of the value set upon it as an article of food, has tended to render them scarce. The sea-board counties of the State now furnish but few in comparison with twenty years ago (1868)."

\section{PSEUDEMYS, Gray.}

P. rugosa, Shaw (Ptychemys, Ag.) Red-bellied Terrapin.

Jaws serrated; neck with yellow stripes; plastron red or partly yellow; marginal plates of carapace with much red; general color above dusky, with red markings.

"Not an abundant species. This and $M$. geographicus have no apparent peculiarities in habits from the tribe to which they belong."

P. hieroglyphica, Holbr. (Trachemys, Ag.) Hieroglyphic Turtle.

Jaws not serrated; olive brown, with broad, reticulated, yellow lines; head small. Habitat-Eastern United States. It is desirable to obtain information about this turtle, which may be mistaken for preceding.

\section{Family CINOSTERNIDZz.}

Stink-pots.

\section{OINOSTERNUM, Wagl.}

C. penneylvanicum, Bosc. (Thrynosternum, Ag.) Small Box, or Mud Turtle.

Anterior lobes of plastron nearly equal, and both capable of closing the shell; the posterior one emarginate; carapace highest posterior to center; dusky brown; light stripes and yellow dots on head and neck. Length, 4 inches.

"This species, notwithstanding its specific name, is not an abundant one in New Jersey. More common in the central and southern than northern counties." 


\section{AROMOOHELYS, Gray.}

A. odoratus, Latr. (Ozotheca, Ag.) Musk Turtle. Stink-pot.

Head large; jaws strong; lobes of plastron incapable of closing shell, though movable; posterior lobe narrower, longer and truncate, with pointed angles; carapace dusky, clouded or spotted; two yellow stripes on each side of head; musky odor. Length, 6 inches.

"This disagreeable species is probably the most abundant representative of the turtle tribe in the State. Every creek and mill-pond seems to abound in them, much to the annoyance of the angler."

\section{Family CHELYDRIDA.}

\section{Snappers.}

CEEL $\dot{Y} D R A$, Schw.

C. serpentina. Common Snapping Turtle.

Shell highest near front; head and neck large; jaws hooked and powerful; tail with a crest of tubercles; plastron small, cross shaped, with narrow bridges; fierce and voracious.

"This species is abundant throughout the State wherever the water is quiet, the mud deep and soft-finned fishes abundant. Mill-ponds and creeks, formed by the draining of extensive meadow lands, are their favorite localities; although they are frequently met with in small brooks and ditches, at a great distance from any water-course of any size. They have no habits that make them obnoxious to the farmer."

\section{Family TRIONYCHIDZ.}

Salt-water Rurtles.

Soft-shelled Turtles.

ASPIDONECTES, Wagl.

A. spinifer, Le S. Common Soft-shelled Turtle.

Body flat, round; carapace not ossified to margins, covered by a leathery skin; head long, pointed, with flexible snout; feet 
broadly webbed; only three toes with claws; nostrils terminal, crescent shaped; plastron white; head, \&c., olive green, with stripes; legs mottled; back olive brown, with dark spots; male with tubercles on front of carapace, smaller than in female; body also longer.

"This salt-water turtle is quite abundant on our sea-board, but is nowhere very numerous. They are found in all the saltwater rivers and creeks."

\section{AMYDA, Ag.}

A. mutica, Less. Leathery Turtle. Soft-shelled Turtle.

Nostrils under tip of snout; a depression along middle of carapace ; no spines on anterior margin, \&z. ; feet not mottled.

"Very rare. An occasional specimen has been met with in the Raritan River. None appear to be found in the Delaware. Occasionally seen in the Hudson."

\section{Order LACERTILIA.}

(SAURII.)

\section{Family IGUANID 2 .}

\section{SCELOPORUS, Wieg.}

S. undulatus, Harl. (tropidolepis.) Tree Swift. Pine-tree Lizard. Fence Lizard.

Head broad, not spinous; greenish, bluish or bronzed, with black, wavy cross-bands above; throat and sides of belly with blue or green; dorsal scales carinated; tail slender, brittle. Length, 7 inches. Varies much in color.

"This and the following are the only true lizards found within State limits, and the present species is much the more commonly met with of the two. It appears to be about equally distributed throughout the State, and disappears from localities in proportion as the timber is cut off. The popular appellation of 'fence 
lizard' is well chosen, as they seem exceedingly partial to rough worm-fences that enclose unfrequented fields. The food of this attractive little animal consists wholly of insects and their larvæ, as found beneath the decayed bark of prostrate trees or fence rails. They are incapable of inflicting any wound, when captured, and are wholly free from the venomous sting not unfrequently attributed to them. Their habits render them a valuable animal, and they should be free from the molestation so common."

\section{Family SCINCID}

Skinks.

FUMEOFS, Wieg.

(Plestiodon.)

F. fasciatus, L. (P. striatus-Abbott's Catalogue.) Blue-tailed Lizard. Head sub-quadrangular; body fusiform; ear large; color blackish, with five yellowish streaks, the middle one forked, on head; tail blue; old specimens reddish. Length, 8 to 11 inches. Prof. Frank L. Nason reports having seen this secretive animal on a mountain ridge three miles west of Midvale, near Wanaque mine.-J. N.

"This beautiful skink is less generally distributed throughout the State, being most usually met with in the dense swamps of the southern counties. They are extremely shy and seminocturnal in their habits, so that unless diligently sought for, are not often seen. The food of this species is insects and their larvæ, which they hunt for diligently under the decaying bark of trees; in which locality, too, they themselves generally rest during the day. The motions of this little animal are the most rapid of any creature of the State fauna. They are very diffcult of capture. They, like the preceding, cannot bite so as to inflict a wound, and are not venomous." 


\title{
Order OPHIDIA.
}

SERPENTS.

\section{Family COLUBRIDEE.}

\author{
Harmless Snakes.
}

"The species belonging to this family are not all harmless, but so far as the family is represented in this State, are so without any exception. They are all of great value to the agriculturist, and the popular prejudice against serpents of all kinds should be done away with, so far, at least, as the following species are concerned." [C. C. A.]

\section{HETERODON, Beauv.}

H. platyrhinus, Latr. Adder. Blowing Viper. Hog-nose Snake.

Brownish, with twenty-eight dark dorsal blotches, besides lateral ones and half rings on tail ; sometimes all black. Length, 30 inches ; ventral plates (gasterosteges), 125 to 150 ; number of rows of scales, 25.

"This abundant species is generally known as the 'adder,' and in consequence of its habit of flattening its head and swelling its neck, when surprised, it is looked upon as very venomous, but is in reality very harmless. The species is sometimes found almost entirely black, and is generally looked upon as a different animal."

\section{TROPIDONOTUS, Kuhl.}

T. sipedon, L. Water Snake. Water Adder.

Brownish; back and sides with each a series of large, square, dark blotches, alternating with each other. Length, 30 to 50 inches ; gasterosteges, 130 to 150 ; number of rows of scales, 23.

"Very abundant. When fully grown is about five feet in length, and appears to be a dangerous reptile, but such is not the case. It feeds upon fish and frogs."

T. leberis, L. Leather Snake. [Garter Snake.]

Chestnut brown; a yellow lateral band and three narrow, black dorsal stripes; scales all carinated. Number of rows of scales, 19 ; gasterosteges, 140 to 150 ; length, 24 inches. 


\section{GEOLOGICAL SURVEY OF NEW JERSEY.}

"This well-known species is similar in all respects to $E$. sirtalis, and equally merits the good will of the gardener. This and the sirtalis are very frequently met with in the yards of our cities."

\section{TROPIDOCLONIUM, Cope.}

T. kirtlandi, Kenn. Kirtland's Snake. Little Red Snake.

Head shiny black; general color brown; belly salmon, with a row of black spots on each side; scales carinated. Number of rows of scales, 19 ; gasterosteges, 115 to 140 ; length, 8 inches. "Ohio to Illinois."-Jordan.

"A single specimen of this beautiful little snake was captured by the writer in 1859 , and a second has been seen, that the author failed to secure. These only are known to have ever been met with. The specimen was described from specimens taken in Ohio."-[C. C. A.] Perhaps refers to the following.

\section{STORERIA, Bd. \& Grd.}

S. occipitomaculata, Stor. Red-bellied Snake.

Grayish or chestnut brown, paler on middle of back, with dots; obscure dots on side; three pale blotches on occiput; belly salmon red. Number of rows of scales, 15 ; gasterosteges, 120 to 125 ; length, 12 inches. United States; chiefly eastward. Abundant.

S. dekayi, Holbr. (Tropidonotus.) De Kay's Brown Snake. [House Snake.]

Grayish brown; clay-colored dorsal band bordered by dotted lines; grayish below; body thickish, tapering towards the small head. Number of rows of scales, 17 ; gasterosteges, 125 to 130 ; length, 12 inches.

"This lively little snake is not a very abundant species, and is frequently met with in yards, about pumps, sinks and other moist places. It feeds largely upon grasshoppers, insects, \&c."

\section{EUT 平NIA, Bd. \& Grd.}

E. sirtalis, L. Common Garter Snake. Striped Snake.

Olivaceous dorsal stripe narrow; lateral stripes broad but faint. Gasterosteges, 130 to 160 ; number of rows of scales, 19 . Very variable. The prominent varieties are : 
Var. ordinata, L.

Stripes dull, but spots distinct.

Var. dorsalis, Bd. \& Grd.

With broad dorsal stripe and row of distinct spots above lateral stripe.

"This numerous species is exceedingly abundant, and is of value to the gardener, from the fact of feeding, during the summer season, very largely upon grasshoppers."

E. saurita, L. Swift Garter Snake. Riband Snake.

Body more slender, with longer tail ; brown, with three yellow stripes; colors bright. Gasterosteges, 150 to 160 ; length, 36 inches. Chiefly east of Alleghanies.

BASCANIUM, Bd. \& Grd.

B. constrictor, L. (Coryphodon, Dum. \& Bib.) Black Snake.

Pitch black; greenish below; chin and throat white; young olive, with rhomboid patches; large and slender. Number of rows of scales, 17 to 19 ; gasterosteges, 170 to 200 ; length, 50 to 60 inches.

"This well-known serpent appears to be growing less abundant every year. They are not as numerous in the northern as in the central and southern counties. The fully-grown specimens measure over six feet. Perfectly harmless."

\section{PITYOPEIS, Holbr.}

P. melanoleucus, Daud. Pine Snake. Bull Snake.

White, with chestnut-brown blotches margined with black, besides other markings. Number of rows of scales, 29 ; gasterosteges, 220 to 230 ; length, 60 inches. Pine woods, New Jersey to Ohio, and southward.-Jordan.

\section{COLUBER, L.}

(Scotophis, Bd. \& Grd.)

C. obsoletus, Say (alleghaniensis, Holbr.) Pilot Snake. Racer.

Black; some scales white edged. Number of rows of scales, 27 ; gasterosteges, 235 ; length, 50 to 75 inches. Massachusetts to Illinois and Texas. Possibly often mistaken for B. constrictor, above. 
C. vulpinus, Bd. \& Grd. Fox Snake.

Light brown, with quadrate, chocolate-colored blotches. Number of rows of scales, 25; gasterosteges, 200 to 210 ; length, 60 inches. Massachusetts to Kansas and northward.-Jordan. If this occurs at all in New Jersey it must be in the northern counties.

\section{PHYLLOPHILOPHIS, Garm.}

(Opheodrys-Abbott's Catalogue.)

P. æstivus, L. Summer Green Snake.

Head conical; neck small; yellowish below; clear green above. Number of rows of scales, 17 ; gasterosteges, 150 to 160 ; length, 30 inches. Southern; northern limit, New Jersey. Abundant in mountains.

"Perhaps is rather more abundant than the following. Their appearance in towns is occasionally noticed, when their uniform - green color and active movements attract very general attention."

\section{CYOLOPEIS, Günth.}

(Liopeltis-Abbott's Catalogue.)

O. vernalis, De K. Green Snake. Grass Snake. Spring Snake

Head elongate; neck slender; eyes large; yellowish below; otherwise uniformly green (bluish in spirits). Number of rows of scales, 15; gasterosteges, 130 to 140 ; length, 20 inches. More northerly than preceding.

"This and the preceding species are neither abundant, and appear to be about equally distributed throughout the various sections of the State. The food consists wholly of the larger insects."

\section{DIADOPHIS, Bd. \& Grd.}

(Ablabes, Dum. \& Bib.)

D. punctatus, L. Ring-necked Snake.

Head depressed; eye large; blue black above; pale orange below; each plate with black spots; yellow occipital ring conspicuous. Number of rows of scales, 15; gasterosteges, 140 to 160 ; length, 15 inches.

"Not an abundant species. In Mercer and the central counties they are but seldom met with, but are found in greater 
numbers in Sussex and Warren counties. They feed upon very young mice and the eggs of birds, in the spring." - [C. C. A.]

\section{OPHIBOLUS, Bd. \& Grd. \\ (Coronella. Lampropeltis.)}

O. getulus, L. Chain Snake. Thunder Snake. King Snake.

Black, with narrow yellow lines forking on flanks, each fork embracing a large black spot; belly checkered. Number of rows of scales, 21 ; gasterosteges, 210 to 225 ; length, 50 inches. Maryland and South.-Jordan.

"This large serpent is found only in the southern counties. It is perfectly harmless. It is called also 'pine snake."

O. doliatus, L. Red Snake. Corn Snake. Calico Snake.

Red, with twenty to twenty-five pairs of black rings, each set enclosing a yellowish one; head red. Number of rows of scales, 21 ; gasterosteges, 180 to 210 ; length 30 to 50 inches. Maryland and South. Very variable, and grades into following species or variety.

"Very similar to the next in all its habits. Perhaps not as frequently met with. The food of this and the following species renders them of value to the agriculturist, in many ways."

Var. triangulus, Boie (C. eximia, De K.) Milk Snake. House Snake. Spotted Adder.

Grayish, with three series of brown, rounded blotches bordered by black; about fifty of them in the dorsal row; an arrowshaped occipital spot. Scales, \&c., as in preceding. Ranges more northerly.

"Not very abundant, and is a stupid, inoffensive species. It feeds principally upon mice and moles."

\section{CARPBOpHIOPS, Gerv.}

(Celuta, Bd. \& Grd.)

C. amcnus, Say. Ground Snake. Milk Snake.

Chestnut brown, glossy; belly salmon red; head small. Number of rows of scales, 13 ; gasterosteges, 120 to 130 ; length, 12 inches.

"This common little snake is well known to farmers as having 
a decided predilection to dairies and cellars. Beyond the trouble caused by their fondness of milk, however, they are of no harm. They feed also upon grasshoppers."

\section{Family CROTALID}

Poisonous Snakes.

These snakes are known by the triangular head, which has a pit between the nostril and eye. There are three American genera, two of which occur on the Atlantic side of the Alleghanies.

\section{CROTALUS, L.}

O. horridus, L. Banded or Northern Rattlesnake.

Tail provided with a ratile of horny epidermal rings; scales on top of head small, the largest in front; general color sulphur brown in various shades, with two rows of confluent, brown, lozenge-shaped spots; tail black; scales carinate. Number of rows of scales, 23 to 25 ; gasterosteges, 165 to 170 ; length, 40 to 60 inches.

"This dreaded serpent is found only in the southern counties of the State, and is not abundant except in a few limited localities. No specimens have been taken north of Trenton or New Brunswick during the past fifty years" (1868).-[C. C. A.]

\section{ANCISTRODON, Beauv.}

(Toxicophis. Trigonocephalus, Holbr.)

A. contortrix, L. Copperhead.

Hazel brown; top of head coppery; back with a series of twenty-five dark blotches of the form of $\mathrm{Y}$; yellowish below, with dark blotches. Number of rows of scales, 23 ; gasterosteges, 150 to 160 ; length, 35 to 40 inches.

"This venomous species is rare within State limits, and only to be met with in the northern mountainous districts. The author has seen a single specimen, which was killed near Newton, Sussex county, in November, 1864."-[C. C. A.] 


\section{CLAgs AMPFIBIA.}

(Batrachia.)

\section{Batrachians.}

These were, of old, classed with the reptiles, but are now seen to be more closely allied to the fishes, constituting the group Ichthyopsida, while the true Reptilia are included with the birds (Aves) in the group Sauropsida.

\section{Order ANura.}

\section{Family RANID za.}

Frogs.

RANA, L.

R. virescens, Kalm (halecina-Abbott's Catalogue.) Leopard Frog. Shad Frog. Common Frog.

General color greenish, sometimes brassy, with many paleedged dark spots in two irregular rows on the back; usually two large spots between the eyes; legs barred above; belly pearly or yellowish; each side of back with a well-marked fold.

"Very abundant. Found in greater numbers along the banks of the larger streams than in the swamps and meadow lands."

R. palustris, Le C. Pickerel Frog.

Brownish, with square spots in four rows; young golden green ; two glandular folds on each side.

"Numerous. This species is among the first to give notice of the approach of spring, by its monotonous 'singing.'"

R. clamata, Daud. (fontinalis, Le C.) Green Frog. Spring Frog.

Bright green, darker on flanks ; everywhere spotted with small dots; white below.

"The most common species of the small frogs. The common name is aptly chosen, as it is essentially a clear-water, springloving creature.

" $R$. horiconensis, Holbr. 
"Not as abundant as some others of the 'frog' family. Useful as a mosquito killer." To be considered as only a variety of the foregoing species, $R$. clamata.

R. catesbiana, Shaw (pipiens, Auct.) Bull Frog.

Greenish, of various shades, with numerous small, indistinct, darker spots; head usually bright pale green; glandular folds not as marked as in preceding. Size large, sometimes over 12 inches.

"Abundant wherever there is sufficient quiet water to warrant the growth of water lilies. Eagerly sought for by epicures."

R. silvatica, Le C. (cantabrigensis, Bd.) Wood Frog.

Reddish brown; a dark band on each side of head through eye; size small; searcely aquatic.

"This handsome frog does not appear to be as numerous as its predecessors. It is found wholly in moist spots in timber land, where it feeds upon the numerous insects found among dead leaves." $R$. cantibrigensis is a distinct variety.

\section{Family SCAPHIOPIDEz.}

\section{Spade Foots.}

\section{SCAPEIOPUS, Holbr.}

S. holbrookii, Harl. (solitarius, Holbr.) Solitary (or Hermit) Spade Foot.

Heel bears a sharp-edged spur; color olive brown; a pale yellow streak on each side; burrows in the ground.

"This little frog is not abundant, and is generally met with, when found, in the southern counties of the State."

\section{Family HYLIDE.}

Tree-toads.

\section{HYLA, Laur.}

H. versicolor, Le C. Common Tree-toad. Green Tree-toad, \&c.

Small-sized arboreal frogs, with toes expanded into disks and noted for their shrill voices. The disks are round, well devel- 
oped ; toes one-third webbed ; very variable in color, green, gray or brown, with irregular dark spots.

"Very abundant throughout the State, although not easily discovered, as the animal is so generally the precise color of the tree it rests upon."

Var. viridis (of $\boldsymbol{H}$, versicolor, above). Green Tree-toad.

"Quite abundant in the central and southern counties. Generally found in swampy lands."

B. pickeringii, Holbr. Pickering's Tree-toad.

Yellowish brown, with dusky rhomboid spots and lines, sometimes arranged in the form of a cross.

"Very common. It is one of the most numerous species of this family found in the State. The 'song' is more melodious than the generality of sounds made by tree-toads. Frequents swampy grounds. The food of all these species consists of insects."

H. andersonii, Bd. Anderson's Tree-tcad, Green and Yellow Treetoad.

Color pea green, with irregular yellow spots on sides; a purplish band on sides of head. Rare.

"A southern species, a single specimen of which was found (by Dr. J. Leidy) in Camden county, in 1863." Rev. Dr. John E. Peters, of Pleasantville, N. J., reports finding a specimen June 1st, 1888, at May's Landing, N. J., in a wet place on the border of a pine barren. Its voice consists of a repetition of a short note (or "peep") three or four times (see Am. Nat., Jan., 1889). Abbott describes its note in captivity as a "keck," nearly like that of the Virginia rail ( $A m$. Nat., Feb., 1890).

\section{AORIS, Dum. \& Bibr.}

A. gryllus, var. crepitans, Bd. Cricket Frog. Savannah Cricket.

Disks small; webs only on hind feet; tympanum indistinct; brownish above; middle of back and head green, with dark triangle between eyes; sides with three oblique blotches; white line from eye to ear.

"Not an abundant species, and more usually met with in the southern third of the State." 


\section{CEOROPHILUS, Bd.}

C. triseriatus, Cope. Little Tree Frog.

Toes not webbed ; tympanum distinct. Abundant near Gloucester (Cope, Bul. 34, U. S. Nat. Mus., 1889).

\section{Family BUFONIDE.}

\section{Toads.}

BUFO, Laur.

B. lentiginosus, var. americanus, Le C. American Hop-toad.

Brownish olive, with yellowish vertebral line and some brownish spots; adults warty; young nearly smooth. Very variable.

"One of the most abundant, if not quite so, of the 'reptiles' of the State's fauna, and probably the combined benefits derived from the other reptiles would not equal that conferred by the toads. It is safe to say that from May 1st to September 1st the toads destroy daily, in our State, one million of flies, or in the time mentioned, one hundred and twenty-three millions. This alone should, and does in a measure, protect this creature from the uncalled-for, unchristian prejudice against the Reptilia as a class, all of which, save the two venomous snakes, are of value to the farmer; and the dead snakes especially so frequently seen upon farms, are in all cases dead losses; and it is hoped that all those who have it in their power to decrease the ignorance of the value of animal life, will use it to the prompt, inestimable advantage of our agricultural interests."

\section{Order urodela.}

\section{Family SALAMANDRIDz.}

Nowts, or Salamanders.

DIEMYOTYLUS, Raf.

(Notophthalmus, Raf.)

D. viridescens, Raf. Spotted Triton. Newt. Evet. Eft. [Salamander.]

Outer and inner toes of hind feet rudimentary; above olive green of varying shades; lemon yellow below; sides with large 
vermilion spots, each surrounded by a black ring; back with a pale streak; belly with dots.

"We have frequently found this salamander in the many brooks that run into the Delaware, on the Jersey side, from Trenton to Manunka Chunk. They lie upon flat stones, frequently out of water, to which they betake themselves on being pursued."-[C. C. A.]

D. miniatus, Raft. Red Eft, or Evet.

Color vermilion red of various shades; paler or yellowish below ; markings and habits same as preceding, of which it may be a variety.-Cope. Come out after a rain.

"This and the preceding species of reptiles, improperly called 'lizards,' are more or less abundant throughout the State. The present species is not as abundant as the foregoing."

\section{Family DesmognathID}

\section{DESMOGNATHUS, Bd.}

D. ochrophca, Cope. Yellow Desmognath.

Brownish yellow, with brown shade on side; dorsal band yellowish; few spots on back, none on belly; tail rounded. Alleghanies of New York and southward.-Jordan. Should occur in our northern counties. Hard to distinguish from the salamanders (Plethodontidoe).

D. fusca, Raf. Dusky Salamander. Water Lizard.

Brown above, with gray or purplish spots; becomes blackish with age ; marbled below; eyes prominent; tail compressed and keeled, as long as head and body; fourteen costal folds.

"This is the most abundant species of the family under consideration. Every brook with a pebbly bottom appears to have any quantity of them. Early in the spring, they may frequently be found some distance from the brook, lying under flat stones. The ground is always moist, however, when they are thus met with. The common name of water lizard is a misnomer, the animal not belonging to the lizard tribe." 


\title{
Family PLETHODONTIDE.
}

\author{
American Salamanders.
}

\section{HEMIDACTYLIUM, Tschudi.}

B. scutatum, Schl. (melanosticta, Gibbes.) Four-toed Salamander.

Ashy brown above; snout yellow; silvery below, with do "like inkspots;" tail slender, nearly twice as long as body head blunt. Rhode Island to Illinois and south.

\section{PLETHODON, Techudi.}

P. cinereus, var. erythronotus, Green. Red-backed Salamander.

Leaden above, with red dorsal band; belly marbled; bod: very slender ; tail rounded; inner toes rudimentary ; costal fold: 16 to 19.

"About as frequently met with as $P$. glutinosus. The im pression that this class of creatures are venomous is erroneous.

P. cinereus, var. cinereus, Green. Gray Salamander.

A variety without dorsal red band.

"Found about rapid streams where there are flat stones, unde which it can conceal itself when pursued. The food of thes animals is small insects."

P. glutinosus, Green. Viscid Salamander. Blue-spotted Salamandes

Black, with gray lateral blotches and smaller dorsal spots body stout; tail rounded; inner toes well developed; like th preceding, spends much time out of water.

"Not unfrequently met with in the hilly sections of the State Very moist land and the bottoms of brooks where it is generall: met with."

\section{SPELERPES, Raf.}

S. bilineatus, Green. Two-striped Salamander. Stripe-backed Sals mander.

Yellow, with a dark line along each side of back; bell: unspotted ; tail not keeled. Costal folds, 14 ; size small.

"Not abundant. More numerous in the northern hilly section of the State. This and the following are very scarce in th central counties." 
S. longicaudus, Green. Cave Salamander. [Slender Salamander.]

Lemon yellow; many black spots on sides, also a median series on back, none on belly; tail keeled, very long, spotted or barred with black. Size large; costal folds, 13.

"Not abundant. Frequents similar rocky land as the above, and is found associated with it."

S. ruber, Daud. (Pseudotriton, Bd.) Red Triton.

Vermilion red, with black or brown spots; head wide. Costal folds, 15 ; size large. A variable species.

"Not as abundant as the next, and found in the same portions of the State."

\section{GYRINOPHILUS, Cope.}

G. porphyriticus, Green (S. salmonea, Stor.) Purple Salamander. [Yellow Triton.]

Uniform purplish gray above; head broad; tail rounded at base, not finned; size large; aquatic. "It snaps fiercely but harmlessly, and throws its body into contortions in terror."Cope. Alleghany system.

"Not abundant. This species is met with about Trenton and the central portions of the State." I should judge from the name "Yellow Triton," bracketed above, that the S. longicaudus was intended.-J. N.

\section{Family AMBLYSTOMIDE.}

Big Salamanders.

\section{AMBLYSTOMA, Trchudi.}

A. Opacum, Grav. (fasciata, Green.) Opaque Salamander.

Black above, with bluish-gray bars; belly dark blue; no dorsal furrow nor enlarged pores on head. Tail, $2 \frac{1}{2}$ inches in length; body stout; costal grooves, 11.

"About as abundant as $A$. tigrinum, and is more generally distributed, although not as abundant in Sussex and Warren counties as in Cape May county." 
A. punctatum, L. (venenosa, subviolacea.) Large Spotted Salamander. Crimson-spotted Triton.

Black above, with series of yellow spots on each side of back; body large, 'broad, depressed and swollen; skin with small pores, through which a whitish fluid exudes; several groups of enlarged pores on head; a strong dorsal groove. Tail, $2 \frac{1}{3}$ inches; costal grooves, 11 .

"Quite an abundant species in some localities. This species is the one so frequently seen in aquaria, where it shows to great advantage, by its graceful movements and the brilliancy of its coloring. The food of this and of the preceding, and of A. jeffersonianum, is flies."

A. conspersum, Cope. Smaller Spotted Salamander.

Lead colored; one or two series of small yellow spots on sides; no dorsal groove; size small; skin smooth. Tail, $2 \frac{1}{2}$ inches; costal grooves, 11.

"The author has only met with a single specimen of this species in New Jersey. It was discovered lately by Mr. Cope, in Chester county, Pennsylvania."-[C. C. A.]

A. tigrinum, Green (ingens). Tiger Salamander, or Triton.

Brownish, with many yellow spots; body thick; head long and narrowish; tail shorter than head and body; color varies from brown to yellow. Costal grooves, 12 ; two tubercles on sole of foot.

"Found only, apparently, in the southern counties of the State. The only specimen ever captured by the writer was in Cape May county, in a dense cedar swamp."-[C. C. A.]

A. bicolor, Hallow. Two-colored Salamander.

Olive brown, yellowish below, rising in blotches on sides; a few large spots above; legs banded; tail yellow, with brown spots; soles with two tubercles. Costal grooves, 11. New Jersey.—Jordan. Beesley's Point, N. J.-Cope.

A. jeffersonianum, Green: Triton. Jefferson's Salamander.

Dark leaden, variable, sometimes with bluish spots ; size small. Costal grooves, 12, but not two tubercles on sole.

"We have not met with this species very frequently. The localities in which such animals are found, and the absence of 
any benefit conferred by them upon the agricultural interest, however, renders the absence of any fact concerning them of no importance."-[C. C. A.]

\section{Crass PIsces.}

\section{Fishes.}

\section{GUB-CIASE MARSTPOBRANCFII.}

(Cyclostomi.)

Eel-shaped fishes, without limbs, ribs, jaws; nasal aperture single and mouth suctorial (circular).

\section{Order hyperotreta.}

Nostril tube-like, penetrates palate; snout with eight barbels; two comb-like series of teeth on tongue; gill apertures far from head. Burrow into the flesh of other fishes.

\section{Family MYXINID Ż. \\ Hagfishes.}

MYXINE, L.

M. glutinosa, L. (limosa, Grd.) Hagfish. Borer. Sleepmarken.

No eyes; two rows of mucous glands below, secreting much slime; blue above, whitish below. Not abundant on our shores.

\section{Order hyperoartia.}

Nasal duct does not penetrate the palate.

\section{Family PETROMYZONTID z.}

Lampreys.

Body naked, cylindrical anteriorly and compressed behind ; mouth armed with horny teeth, resting on papillæ; eyes present; seven 
separate gill openings on each side; the young are toothless and have. rudimentary eyes.

\section{AMMOCGTES, Dum.}

Maxillary tooth single; lingual teeth not pectinated.

A. appendix, De K. (Ichthyomyzon, Grd.) Lamprey.

Brown, tinged with blue; fins pale amber; one large double tooth in lower side of mouth; dorsal fin begins in front of middle of body; vent near posterior third of body, with conspicuous "appendix" in males in spring. Streams of Southern New England and New York, representing $A$. niger, small black lamprey, of region west of Alleghanies (length, 6 to 10 inches), which, however, is distinguished by having dorsal fin start further back.

"This small species is very abundant in the majority of our creeks that communicate directly with the rivers. It is very similar in all its habits to the lamper eel."

\section{PETROMYZON, L.}

Maxillary teeth two or three; lingual teeth pectinate.

\section{P. marinus, I. (americanus, Le S.) Great Sea Lamprey.}

Head scarcely longer than gill region; numerous teeth on large buccal disk, arranged in oblique series; color olive brown, mottled with blackish patches; dull brownish below. Length, 24 to 36 inches. Enters streams in spring, to spawn.

"This species is quite common in spring along our coast, entering the bays and rivers. It is valued as an article of food, and many are taken and offered for sale in our fish-markets."

P. marinus, var, nigricans, Le S. Lamper Eel. Large Black Lamprey.

Head one-third longer than "chest;" color plain bluish black above, pale below. Length, 12 inches. Usually described from a distinct variety (dorsatus) found in Cayuga Lake, New York, which has bead a little longer and a fleshy ridge on back in front of fin. Our nigricans is supposed to be the young of the preceding species.

"An allied species that is found wherever the previous one is met with." 


\section{BUB-CIAGS ELAGMOBRANGFI.}

Fishes with cartilaginous skeleton; heterocercal tail ; no air-bladder; embryo with deciduous external gills.

\section{Section SELACHII.}

(Plagiostomi.)

\section{Order SQUALI.}

Sharks.

\section{Famly SPINACIDA.}

\section{Dogfishes.}

Body elongated; head depressed; eyes lateral, without nictitating membrane; mouth and nostrils inferior; five gill openings on each side; two dorsal fins with spines; no anal fin.

SQUALUS, L.

(Acanthias, Risso.)

S. acanthias, L. (americanus, Stor., sucklii, Grd.) Spiked Dogfish. Bone Dog: Skittle Dog. Hoe.

Body slender; snout pointed; head, $6 \frac{1}{2}$ inches; slate color above, with white spots on back; pale below ; teeth small, alike in both jaws; spiracles wide, just back of eyes; gill openings narrow. Length, 12 to 36 inches; weight, 5 to 15 pounds. Their livers valued for oil.

"This is a common species along our coast, and according to Storer, are so numerous at Cape Cod as to form an important fishery for the oil they furnish." 


\section{Family carchariddz.}

Two dorsal and an anal fin, without spines; eyes with nictitating membranes.

\section{MUSTELUS, Cuv.}

M. canie, Mitch. (hinnulus, Blainv., vulgaris.) Dogfish. Dog Shark. Smooth Hound.

Mouth with labial folds; teeth flat, without cutting edges; no pit at root of tail; no placenta in development. Smallest of our sharks.

"Quite common, and met with as the thresher."

\section{GALEOOERDO, M. \& H.}

G. tigrinus, M. \& H. Tiger Shark.

Teeth with sharp edges, serrated; a pit at root of tail; a double notch on caudal fin; color brown, with dark spots ; caudal fin about one-third of whole length; rather large. Ranges from Cape Cod to the Indian Ocean.

\section{CAROHARIAS, Raf.}

(Cynocephalus. Squalus. Prionodon. Eulamia.)

O. obscurus, Le S. (Platypodon, Gill.) Dusky Shark.

No spiracles; teeth serrated, upper ones oblique, notched on outer margin, in lower jaw clavate; first dorsal fin large, close behind the pectoral ; color dark, clear blue above, white below; large, reaching ten feet. "Frequently taken on our coast."Jordan.

"Not a common species."- [C. C. A.]

O. coruleus, De K. (milberti, caudata, De K.) Small Blue Shark.

Length of snout equal to width of mouth; color slate blue, white below ; fins with black tips; pectorals rather small; upper teeth serrate, not notched; size much as preceding.

"Prof. Baird reports this species quite numerous at Beesley's Point. It is about equally abundant along our coast. Specimens occasionally wander up Delaware Bay, but do not leave the salt water." 


\section{ISOGOMPHODON, Gill.}

(Carcharias. Prionodon.)

I. limbatus, M. \& H. Spotted-fin Shark.

Teeth scarcely serrated, narrow in both jaws; snout short and pointed ; gill openings wide; upper edge of pectorals four times length of lower margin; some black on fins. Tropical ; straying north.

\section{SOOLIODON, M. \& B.}

(Squalus. Carcharias.)

S. terræ-novæ, Rich. Sharp-nosed Shark.

Teeth flat and oblique, with points turned to right or left away from center; pectoral fins large; ventrals small; color gray; tail fin black edged. Size rather small. Newfoundland to South America.

\section{Family SPHYRNIDE.}

\section{Hammerheads.}

\section{SPHYRNA, Raf.}

(Squalus. Cestracion, \&c.)

S. tiburo, L. (Section Reniceps.) Shovel-head Shark. Bonnet-head.

Head kidney shaped; eyes far separated, with nostrils near; front margin of head a semicircle; ashy color. Length, 3 to 6 feet.

"Professor Baird met with this species at Beesley's Point."

S. zygæna, L. (Section Sphyrna), (malleus, subarcuatus.) Hammerhead.

Head more truly hammer shaped, width twice its length. Common from Cape Cod southward. Size large.

"Only occasional specimens of the 'hammerhead' are met with along our coast, but this species is more usually seen than the spiked dogfish."

\section{Family ALOPIIDZE.}

(Lamnoidea in part.)

\section{Thresher Sharks.}

Body moderately elongate ; snoút short ; teeth alike, flat, triangular, not serrated; the third upper tooth much smaller than rest; no nicti- 
tating membrane; spiracles behind and near eye; first dorsal fin large; tail fin as long as body, with a pit at its root and a notch near tip.

\section{ALOPIAS, Raf.}

(Squalus. Alopecias.)

A. vulpes, Gmel. Thresher. Fox Shark. Swingle-tail. Long-tail Sharks, \&c.

For characteristics, see family characters.

"This is a common species, frequently taken on hooks baited for other fish."

\section{Family ODONTASPID}

Sand Sharks.

Mouth wide; teeth large, long and narrow; gill openings all in front of pectorals; dorsal fins nearly equal; pectorals short; no nictitating membrane; spiracles pore-like.

\section{ODONTASPIS, Ag.}

(Carcharias.)

\section{O. littoralis, Mitch. (americanus.) Sand Shark. Shovel-nose.}

Teeth awl-like; no basal cusps on first and fourth upper teeth and first lower; body elongate; head pointed; fins small ; color gray. Length, 4 to 6 feet. Voracious.

"This species, described in full by the author, was taken off Beesley's Point."-[C. C. A.] '

\section{Family LAMNID}

The Porbeagles.

Size large; body stout; mouth wide; teeth large; lobes of tail fin nearly equal; first dorsal and pectorals large; second dorsal and anal very small; spiracles minute br absent; gill openings wide and lateral. 
ISURUS, Raf. (Oxyrhina. Isuropsis.)

I. dekayi, Gill. (punctata, De K., glaucus.) Mackerel Shark. Porbeagle. Snout long and pointed; teeth long, lanceolate, with entire edges without basal cusps; first dorsal inserted well behind the pectorals; dark bluish gray above, white below; middle teeth longest. Length, 10 feet. I. glaucus is the Asiatic species, with shorter pectorals.

"This large species is not unfrequently seen and taken along our coast. It chases the schools of mackerel generally, and is seen on our coast frequently or not, as the latter fish are abundant or otherwise."

\section{Family CETORHINIDza.}

Basking Sharks.

Very large, with wide gill openings that reach nearly to middle of throat; teeth small and conical; spiracles small, above corners of mouth; first dorsal large and midway between the large pectorals and the ventrals.

\section{OETORHINUS, Blainv.}

(Bqualus. Selachus.)

C. maximus, Gunner. Basking Shark.

Skin very rough; head and eyes small; nose blunt; teeth in six or more rows of two hundred in each row ; largest of sharks. Length, 40 feet at times.

"Occasionally, in August and September, a specimen of this species is seen, but they are seldom captured. They are a northern species that are seen on our coast only as stragglers."

\section{Order RalaE.}

(RAJIDES. BATOIDEI.)

Five pairs of gill openings on the lower surface; no anal fin; dorsal fin on tail ; body flat, formed laterally of the expanded pectorals ; tail slender, with small fin. 


\section{Family TORPEDINID王.}

\section{Eleotric Rays.}

Body smooth, sharply marked off from thickish tail ; rayed caudal fin; longitudinal fold on each side of tail ; two dorsal fins; spiracles well behind eyes; electric organs present.

\section{TORPFDO, Dum.}

T. occidentalis, Stor. 'Crampfish. Torpedo. Numbfish.

Mouth small, with pointed teeth; first dorsal fin more than twice as large as second; edges of spiracles smooth ; color black, with obscure darker spots. Atlantic coast. Not common.

\section{Family RAIIDE.}

\section{Skates.}

Disk rhombic, rough ; tail long, spiny; pectorals extend to snout; ventrals large; eggs laid in horny cases with two "horns" at each end.

\section{RAIA, L. .}

R. erinacea, Mitch. (eglanteria.) Common Skate. Hedge-hog Raye. Little Skate. Tobacco-box.

No angle to disk at snout; about fifty rows of teeth; large, close-set, hooked spines on front of pectorals; middle of back nearly smooth; groups of small scales on each side of vent, in females; middle teeth sharp in males, blunt in females; color light brown, with small darker spots; females larger. The smallest of our skates; abundant northward.

"This species is rare. Dr. Mitchill found one on our coast, which is the only specimen recorded as having been seen from New Jersey."

R. ocellata, Mitch. (diaphanes in part, Stor.) Big Skate Ray.

Much like last, but attains length of three feet and has more spines on back, and nearly one hundred rows of teeth. 
"Not uncommon. They are mostly taken in the spring, and are occasionally eaten, but are not prized as an article of food."

R. radiata, Donov. (americana, De K.) Starry Ray. Prickly Ray.

Disk forms an obtuse angle at tip of snout; about forty rows of teeth; besides spines as above, are strong spines with expanded plate-like bases, one or two in front of eye, one between eye and spiracle, a pair on shoulders and fourteen in a dorsal row; teeth hooked in male; females larger and more spinous.

"Rare. The writer has never met with a specimen, and De Kay reports having seen but one, taken at Staten Island."[C. C. A.]

R. eglanteria, Lac. Brier Ray.

With acute snout; color brown, with bands, bars, blotches, \&c. ; with small, very sharp prickles and larger spines in various regions; two rows on each side of tail. Length, 2 feet. Not common.

R. lævis, Mitch. Barndoor Skate.

Angle at tip of snout much produced and shovel-like; rows of teeth nearly forty; spines few and small, most spines on female, as usual; color variable, brownish, with paler spots. Virginia northward.

"Not uncommon. In 1860 a specimen was taken in the Delaware River, above Philadelphia, and exposed in the Trenton market for sale. It was captured in May, in a shad-net, and lived five days out of water, and was afterward kept alive several weeks in a tank made for it."

\section{Family TRIGONID 2 .}

\section{Sting Rays.}

Disk broader than long; pectorals confluent in front; tail usually whip-like, never bears two dorsals, and usually with a vertical fold and a retrorsely-serrated spine (or several), capable of inflicting a serious wound; sexes alike; ovoviviparous. 
TRYGON, Adan.

(Dasybatis, Walbaum. Dasyatis, Raf.)

T. centrura, Mitch. (hastata.) Common Sting Ray. Clam-cracker. Stingaree.

(T. sayi, Le S., is a more southerly species.) Tail more than twice length of disk (less in sayi); round on top, compressed, with lateral series of large tubercles; snout not prominent; teeth small ; color brownish. Length, 8 feet. T. sayi is supposed to be young of other species. Varieties of centrura (perhaps young in different stages), with shorter tails, smoother skin, \&c., have been distinguished. This species is designated T. sayi by C. C. A.

"Lesseur describes a specimen of ray from New Jersey, in the Journal of the Philadelphia Academy, which is reported by Prof. Baird to have been very abundant at Beesley's Point. It inflicts a poisonous wound with its tail, if not handled with eare."

\section{Family MYLIOBATID 72.}

\section{Eagle Rays.}

Disk broad; pectoral fins not continued to end of snout, but are replaced here by two fleshy "cephalic fins;" tail very slender; fin near its root and a spine; skull raised so eyes and spiracles are lateral ; teeth large, hexangular; sexes alike.

\section{MYLIOBATIS, Dum.}

M. freminvillei, Le S. (acuta, Stor., bispinosus, Dum.) Eagle Ray.

Median teeth very broad; disk broad, equal to length of tail; skin smooth; a white prominence over eye; small teeth in three rows at sides of median ones; color reddish brown, with black tail. Cape Cod to Brazil. Not uncommon.

\section{RHINOPTERA, Kuhl.}

R. quadriloba, Le S. Cow-nosed Ray.

Disk emarginate on "snout," which bears two lobed " cephalic 
fins" below; teeth in seven rows, middle teeth not so large as in preceding; skin nearly smooth; brownish. Attains a large size.

"This is quite common along our coast, especially in September. It feeds largely upon clams, having jaws and teeth sufficiently powerful to crush the shells."

\section{Family CEPHALOPTERIDze.}

\section{Sea Devils.}

Very large; disk broader than long; pectorals not extended on sides of head, but anterior part developed as two long, ear-like appendages; mouth wide; teeth small, in many series; eyes well separated, also nostrils; skin rough; sexes alike; ovoviviparous.

\section{MANTA, Banc.}

(Ceratoptera, M. \& H.)

M. birostris, Walf. (vampyrus, Mitch.) Sea Devil. Devil Fish.

Disk broad, with acute exterior angles and concave posterior margins of pectorals; head truncate, with long cephalic fins; teeth present in lower jaw only; tail whip-like, without spine, as long as width of disk; teeth, one hundred longitudinal series; skin rough, brownish. Attains a width of 20 feet. Tropical; northward occasionally.

"A specimen of this monster is reported to have been taken in Delaware Bay about 1810. There have been no captures along the coast since, that have been recorded. It is seen along the southern coasts occasionally, but is rare every where" (1868). 


\section{SuB-Cuase GANOIOEI.}

Fishes having many structural characters similar to the Elasmobranchs, but with bony plates in skin instead of scales.

\section{Section CHONDROSTEI.}

\section{Order GLANiOSTOMI.}

\section{Family ACIPENSERIDE.}

\section{Sturgeons.}

Body nearly cylindrical, armed with five rows of bony bucklers, each terminating in a spine; mouth small, without teeth, but with barbels; eyes small; gills four besides the opercular gill; no branchiostegals; head covered by bony plates united by sutures; tail heterocercal.

\section{AOIPENSER, L.}

A. sturio, var. oxyrhynchus, Mitch. American Sturgeon.

Snout conical, sharp, depressed; a small spiracle over eye; mouth inferior; barbels between mouth and snout; plates on sides of tail ; not so many lateral plates (twenty-seven to twentynine) as in European sturio. Ascend rivers of Atlantic coast in spring to spawn.

"This is the more common of the two species of sturgeon met with in the Delaware River. They were formerly much more abundant than at present, and it would seem as though they then were generally of much greater dimensions. They are taken in the Delaware as far up as Port Jervis, N. Y."

A. brevirostrie, Le S. Short-nosed Sturgeon.

Snout one-fourth length of head; bony plates smaller and further apart. 
"This species is met with in the Delaware in proportion'to the other, at about five to one. It never is taken of as large a size. As an article of food it is equally good."

\section{Section HOLOSTEI.}

\section{Order GiNGlymodi.}

\section{Family LEPIDOSTEID E.}

\section{Gar Pikes.}

Tail heterocercal ; body covered with rhombic plates, imbricated in oblique series running downward and backward; jaws beak-like, the upper the longer; maxillary bones divided into several; lower jaw of several pieces; mouth armed with series of small and of large teeth, the latter set in a groove and having pulp cavities; no spiracles; pseudobranehix, four gills and an additional slit present; air-bladder lung-like, with a glottis; dorsal fin nearly opposite anal.

\section{LEPIDOSTEUS, LAC}

L. osseus, L. (huronensis, oxyuris.) Common Gar Pike. Billfish. Long-nosed Gar. Bony Gar.

Only one row of large, several rows of small teeth; snout slender, more than twice length of head; olivaceous, pale silvery below; posterior part of body with round black spots; a black lateral band in very young. Length, 2 to 5 feet.

"This, the largest of the river fish found in the State, with the exception of the sturgeon, is not abundant in any of the streams, but appears to be more numerous in the Delaware River than elsewhere within State limits. It remains in the river probably throughout the year, and during the summer secretes itself in the patches of tape-grass that grow on the bottom of the stream, and from it dart out ever and anon, to seize some one of the many mammoth chubs that are ever moving about.

"The young of this species are beautifully spotted, with round markings of a dark brown, and until over two feet in length, 
they are the most beautiful of the fresh-water fishes of the State. The young, however, are seldom met with, more seldom, indeed, than adult specimens, which seems to show that the species does not spawn in fresh water, at least not in the Delaware, unless it is in the bay, and that only the grown specimens come, as a general thing, into strictly fresh water.

"This species has been seen in the Delaware at Water Gap, but generally they do not go above Trenton."

L. platystomus, Raf. (crassus.) Short-nosed Gar Pike.

Beak a little longer than rest of head. West of Alleghanies; more abundant southward. Fresh water. Doubtful if same as crassus referred to in following.

"Prof. Cope, in the Proceedings of the Academy of Natural Sciences of Philadelphia, makes mention of this species with the following note: 'The type specimen was probably taken in brackish water at Bombay Hook, near the mouth of the Delaware River.' This will indicate a species of gar which must be very rare in the Delaware, as among many specimens nothing agreeing with it has been met with by the writer. In habits it is probably very similar to the preceding, which, however, is a fresh-water fish."

\section{Bub-CLASS TELEOSTEI.*}

(Skeleton bony.)

\section{Section PHYSOSTOMI.}

Fishes having an open duct between the air-bladder and the gullet.

1

\section{Order Nematognathi.}

No sub-opercle nor symplectic; supra-occipital and parietals anchylosed, also co-ossification of anterior vertebræ; precoracoid present; skin uaked or with bony plates.

\footnotetext{
*All the Physostomes except the orders Nematognathi and Apodes, and all the Physoclists except the Pediculati, Plectognathi and Lophobranchii, are often grouped into one order, the Teleocephali.
} 


\section{Family SILURIDIE.}

\section{Catfishes.}

Anterior part of head with two or more barbels, the bases of the longest formed by the modified maxillaries; margin of upper jaw formed by the premaxillaries only ; an operculum is present; an adipose fin usually ; anterior rays of dorsals and pectorals spinous ; airbladder connected with ear by means of auditory ossicles. Our species belong to the division Protopterce, in which the dorsal fin has not more than twelve soft rays.

\section{NOTURUS, Raf.}

N. flavus, Raf. (occidentalis, platycephalus.) Yellow Stone Cat.

Anterior and posterior part of nostril widely separate, the latter provided with a barbel; three other pairs of barbels; head depressed, vomer and palatines toothless; mouth large; oyes small; teeth in a wide band; branchiostegals nine; dorsal with seven branched rays; adipose fin notched, not free posteriorly; tail fin obliquely truncate, ventral edge shortest; poison gland connected with pectoral spine; color yellow brown, blackish above; fins yellow edged; dorsal spine short; attains length of a foot. Vermont to Virginia and westward; common.

N. gyrinue, Mitch. (sialis, Jord.) Tadpole Stone Cat.

Pectoral spines half as long as head; color pale yellowish brown, with dark streaks on sides; slender; almost ribbon shaped behind; thirteen rays in anal. Common in lake region of New York. Doubtful if in New Jersey.

\section{AMIURUS, Raf.}

(Pimelodus.)

A. catus, L. (atrarius, De K.) Bull-head. Black Catfish. Horned Pout. Small Catfish. Schuylkill Cat, \&c.

Adipose fin free posteriorly; head flat, wedge shaped; skin thick; branchiostegals, eight to eleven; dorsal fin higher than long, with six branched rays; lateral line incomplete; caudal fin truncate; color varies from nearly black to yellowish; anal fin about twenty-one rays. Length, 18 inches.

"This fine species is not frequently met with, and only in the 
rivers, where occasionally specimens are captured, associated with the following common species."

A. vulgaris, Thomps. (dekayi, ailurus.) Long-jawed Cat. Common Catfish.

Lower jaw projects beyond the upper; head longer than broad and narrowed in front; profile steep and convex; color dark reddish or blackish; size of foregoing.

"This is the most abundant species of the catfish found in the State. It is a lover of quiet waters, with a deep deposit of mud on the bottom of the stream. It would not be a misnomer to designate it as the 'mud' catfish. They afford moderate sport to the angler, and, except in July and August, are a fair article of food. They are less abundant in the smaller creeks of the northern part of the State."

A. natalis, Le S., var, cupreus, Jord. (Silurus lividus, Raf., \&c.) Yellow Cat. Chubby Cat.

Body stout, with large head; upper jaw projecting; color yellowish brown. This may possibly occur in the valley of the Delaware, but it is difficult to distinguish species so variable.

\section{ICTALURUS, Raf.}

I. albidus, Le S. White Catfish. Channel Cat of the Potomac.

Body slender, compressed; head conical ; branchiostegals eight to nine; six rays in dorsal fin; caudal deeply forked; mouth rather narrow, upper jaw longer; rays of anal fin about twenty-. one; pale olive bluish above and silvery below. Length, 18 inches.

"This, as an article of food, is the finest of our catfish species. They are very abundant in tide-water streams, often associated with the white perch, and afford excellent sport to the angler. Large quantities appear in our markets."

I. punctatus, Raf. (Pimelodus coerulescens and many others.) Common Channel Cat. Blue Cat. White Cat, \&c.

Eye large; anal fin short; a complete bony ridge from occiput to dorsal fin; color bluish silvery, with small, round, dark spots ; spines long; skin thin ; anal fin short; attains a weight of over twenty pounds. Variable. Probably to be found in the Delaware. 


\section{ARIUঞ, Cuv. \& Val.}

(Ariopsis, Gill.)

A. felis, L. (milberti, Cuv. \& Val.) Sea Catfish.

Anterior and posterior nostrils close together; lower jaw has four barbels; skull with fontanelle; dorsal fin short, rays seven; adipose free behind ; tail forked; bony bucklers in neck region; steel blue above, silvery below; mouth small. Length, 24 inches. Cape Cod to Florida; common southward.

"It is somewhat doubtful if this species is met with on our coast, although said to have been taken at New York."

\section{AึLURICHTHYS, Bd. \& Grd.}

Af. marinus, Mitch. Oceanic Catfish. Gaff-topsail.

Lower jaw with two barbels; maxillary barbels long; large fontanelle; spines end in a filament. Cape Cod to Mexico.

"This large ocean species is at times very common along our coast, and is frequently met with of immense size. It has been known to ascend our rivers, but not farther up the Delaware, we believe, than Philadelphia."

\section{Order eVENTOGNATHI.}

\section{(PLECTOSPONDYLI.)}

Physostomes with opercular bones all present, and a symplectic; no interclavicle; four anterior vertebræ co-ossified.

\section{Family CaTOSTOMID z.}

\section{Suckers.}

Jaws toothless; brain case extends between the orbits; numerous pharyngeal teeth ; maxillaries form part of upper jaw; head conoid; mouth protractile, with fleshy lips; branchiostegals three; four gills and a posterior slit; head naked; body with cycloid scales; dorsal fin long; anal short; caudal forked; air-bladder with transverse constrictions; flesh full of small bones and of poor flavor. 


\section{ICTIOBUS, Raf.}

(Carpiodes.)

I. cyprinus, Le S. (C. velifer, Cope.) Silvery Carp Sucker. Skim-back.

Sailfish. Spearfish. Quill-back.

Dorsal fin long, rays twenty-six; fontanelle present; scales large ; mouth small and horizontal, with thin lips ; muzzle conic obtuse; eye large. Chesapeake Bay to Mississippi Valley.

\section{OATOSTOMUS, LeS.}

(Cyprinus. Fylomyzon, Ag.)

C. commersoni, Lac. (teres, bostoniensis, communis.) Common Sucker. White Sucker. Brook Sucker. Fine-scaled Sucker.

Fontanelle present; body elongate, heavy at shoulders, with large head, flat above; dorsal fins short, rays nine to fourteen; mouth inferior, with thick lips, the lower with two lobes; color olivaceous; males in spring with rosy lateral bands; young brown, mottled. Length, 18 inches.

"The sucker is found generally in the rivers and larger creeks having easy communication with them. Early in the spring they accumulate in great quantities at the mouths of creeks, and are taken in great numbers from such localities. At this time of year they are an excellent article of food, but as the waters are warmer they grow soft, and have a muddy taste."

C. nigricans, Le S. (Hypentelium.) Hog Sucker. Black Sucker. Stone Roller. Mud Sucker. Orawl-a-bottom. Hammerhead. Hog Molly. Toter. Stone Lugger, \&c.

Head flat and concave between eyes; upper lip very thick and with eight to ten series of papillæ on its free margin ; pectoral fins very large; dorsal ten to eleven rays; eye rather small; olivaceous, with brassy luster on sides; white below; back brown, with blotches; young variegated. Attains a length of two feet. Ascend streams in spring to spawn.

"This species is nowhere abundant in the State, but is met with generally in company with the following species. It is a lover of mud and quiet water, and is less active and restless than the mullet. The writer has met with more black suckers in Crosswicks Creek, Burlington county, than elsewhere in the State."-[C. C. A.] 


\section{ERIMYZON, Jord.}

(Moxostoma, Ag.)

E. sucetta, Lac. (M. oblongum.) Creekfish. Chub Sucker. Mullet.

Lateral line wanting; body short and deep; dusky above, brassy on sides and below; young with bands and bars; spring males with six tubercles on head; variable; fins rarely reddish. Length, 10 inches or less.

"This species, in a majority of our streams, is the most abundantly represented of any of the family. Although met with in the rivers in summer, they are never so common as in smaller creeks having quiet waters. It is strictly a mud-loving species, and like $C$. commersoni, is worthless as an article of food, except during the winter and early spring."

\section{MINYTREMA, Jord.}

M. melanops, Raf. Spotted Mullet. Striped Sucker.

Each scale has a black spot, which forms stripes along sides; adults only show traces of lateral line; spring males with many small tubercles on head; dorsal fin high, with twelve rays; dusky above, silvery coppery below. Length, 18 inches. Usually confused with preceding. Should be looked for.

\section{MOXOSTOMA, Raf.}

(Ptychostomus, Ag.)

M. macrolopidotum, Le S. (robustus, oneida, \&c.) Eastern Red Horse. Lake Mullet. White Sucker. Large-scaled Sucker.

Lateral line complete, scales large, fontanelle present; airbladder in three parts; lower lips not deeply cleft; body compressed; dorsal fin thirteen rays; lips plicate; lower fins red; back smoky; sides reflect brownish and golden. Length, 2 feet. Vermont to South Carolina (and westward as a distinct variety). 


\section{Family CTPRINIDa.}

Carps and Minnows.

Margin of upper jaw formed by premaxillaries only; head naked; branchiostegals three; gills four, slits five, with a pseudobranch; ventral fins abdominal; air-bladder large, often constricted into two lobes.

\section{CHROSOMUS, Raf.}

\section{(Iuxilus. Leuciscus.)}

C. erythrogaster, Raf., var. eos, Cope. Red-bellied Dace.

Lateral line incomplete; dorsal fin well back, short, without spine; sides of body with two black stripes, faint in female; head pointed; mouth terminal and oblique; fins and scales small; color brownish olive, with dusky line on back; silvery on sides and belly, scarlet in males in spring, and fins yellow. Length, $2 \frac{1}{2}$ inches; dorsal rays, 8 ; anal rays, 8 ; lateral lines, 77. Susquehanna basin; possibly also Delaware basin.

\section{HYBOGNATHUS, Ag.}

В. argyrites, Grd. (nuchalis, osmerinus, Cope, regius.) Silvery Minnow.

Lateral line complete; mouth oblique; dorsal over ventrals; scales large; eye large; olivaceous green above; sides silvery; head large; upper jaw heavy, lower thin; fins unspotted. Dorsal rays, 8 ; anal rays, 7 ; length, 5 inches or less. Var. nuchalis, Ag., ranges west, is smaller and has mouth horizontal; var. regius, Grd., is larger and more southerly.

\section{HYBORHYNCEUS, Ag.}

H. notatus, Raf. (Minnilus, Raf., perspiouus, Grd.) Blunt-nosed Minnow.

First ray of dorsal short and spine-like; head short; mouth small and inferior, upper jaw protractile; alimentary canal long; fins short, a black spot on dorsal; males with about fourteen large tubercles on snout in spring; lateral line complete; body elongate; brownish or bluish. Length, 3 to 4 inches. Var. superciliosus, found associated with it, has a broader head and a distinct barbel at each angle of mouth. New York to Tennessee. 


\section{HEMITREMIA, Cope.}

H. bifrenata, Cope (Hybopsis). Eastern Hemitremia. Minnow.

Lateral line incomplete; intestine short; dorsal over ventrals ; scales large ; teeth hooked, with grinding surface ; body slender; snout obtuse; jaws oblique; eye large; straw colored, with a black band on sides, silvery below. Dorsal rays, 8 ; length, $1 \frac{1}{2}$ to 2 inches.

"Not as abundant as the following."

\section{OLIOLA, Grd.}

C. procne, Cope (Hybognathus, Hybopsis, Leuciscus). Minnow.

Lateral line complete; dorsal behind ventrals ; males in spring prickly, with white and red on fins; body slender; muzzle obtuse; mouth small, inferior, horizontal ; eye large; olivaceous; a dark dorsal line and leaden lateral band overlying black pigment. Length, $2 \frac{1}{2}$ inches; lateral lines, 32 to 37.

"This and the foregoing allied species are more or less numerous in the Delaware and Raritan Rivers and the inflowing creeks. Their habits are similar and uninteresting."

C. hudsonia, Clint. (Clupea, Hybopsis, Leuciscus, Hudsonius fluviatilis.) Silvery Minnow. Spawn-eater.

Head short; muzzle blunt, decurved; top of head flattened, somewhat concave between eyes; jaws horizontal; a dusky spot at base of caudal in young; sides with a broad silvery band; tail fin long. Length, 4 to 8 inches.

"This species is rare, although the writer has met with it in several widely-separated streams. Not numerous in the Delaware River."-[C. C. A.]

C. analostana, Grd. (Cyprinella, Luxilus, Hypsilepis kentuckiensis, Leuciscus, Photogensis spilopterus.) Silver-fin. Shiner.

Teeth serrate, with narrow grinding surfaces; body somewhat compressed, gently arched above and below; mouth small and oblique; lower jaw received within upper; eye small; color leaden silvery; blue in males; a dark vertebral line; fins charged with white pigment in males in spring, also head and front covered with small tubercles. Dorsal and anal rays, 8 ; length, 4 inches; dorsal fin with black spot. 
"This species is numerically ahead of any cyprinoid in the State, if we except the chub. Thousands swarm every brook, and often actually crowd each other to their destruction. Found in the rivers and creeks as well as brooks."

\section{MINNILUS, Raf.}

(Luxilus. Hypsilepis. Lythrurus, \&c.)

M. cornutus, Mitch., var. cornutus (chrysocephalus, Plargyrus argentatus, \&c.) Common Shiner. Red-fin. Dace. Rough-head.

Teeth with narrow grinding surface; scales large, but only narrowly exposed; abdomen rounded; males in spring with red (not white) fins, and with tubercles on head; snout blunt; body compressed and growing deeper in front with age; mouth nearly horizontal ; dorsal over ventrals in young, further back with age; steel blue above, with golden bands; sides silvery (rosy in spring males); twenty-two to twenty-five scales in front of dorsal fin; fewer in western and southern varieties. Length, 5 to 8 inches.

"Very abundant in all the streams of flowing, cool water, but apparently more numerous as we ascend into the northern counties of the State."

M. chalybæus, Cope (Hybopsis). Pigmy Minnow.

Body with abruptly-elevated back; head flat above, narrow, with pointed muzzle; mouth oblique, lower jaw the longer; eye large; eighteen scales in front of dorsal; brownish above, a broad, black lateral band; belly straw colored; orange in spring males. Length, $1 \frac{1}{2}$ to 2 inches.

"Quite a common species, generally found associated with the Clinostomus and the many-banded minnows."

REINIOHTHYY, Ag.

(Argyreus, \&c.)

R. cataractæ, Cuv. \& Val. (nasutus, Ceratichthys, Leuciscus, Gobio.) Long-nosed Dace.

Body not much compressed; mouth small, upper jaw not protractile; a barbel on maxillary; teeth hooked, without grinding surface; scales small; dorsal behind ventrals; head long, muzzle flat, narrow and prominent; pectoral fins enlarged in male; color olivaceous, paler below, with dusky points; back nearly black 
or mottled; a black spot on opercle; no black lateral bands; spring males with lips, cheeks and lower fins crimson. Doreal rays, 8 ; length, 5 inches. In clear and boisterous streams.

"This less handsome species is not as abundant anywhere in the State as the next, and is generally found associated with it."

R. atronasus, Mitch. (Cyprinus.) Black-nosed Dace.

Barbel minute; dusky silvery below, with a dark lateral band from snout to tail fin; in spring males this (or sometimes whole body). crimson; in summer orange. Dorsal rays, 7; lateral lines, 64 ; length, 3 inches.

"This is a very common species, found in all the spring-water brooks of every county of the State. Its habits present nothing peculiar."

\section{OERATIOHTHYS, Bd.}

(Nocomis. Hybopsis.)

C. biguttatus, Kirt. (Semotilus, nebrascensis, cyclotis, stigmaticus.) Horny-head. Horned Chub. Jerker. River Chub.

Barbel on maxillaries; dorsal nearly over ventrals; body robust; head large ; snout conical and blunt; mouth large, lower jaw the shorter; eye small; eighteen scales in front of dorsal; bluish above; sides with coppery and green; belly pale, not silvery, rosy in spring males; fins pale orange, without black spot; a crimson spot on side of head in spring males; sort of crest on head, covered with tubercles. Length, 6 to 9 inches. The most widely diffused of Cyprinidoe; everywhere abundant from Pennsylvania to Utah. Not quoted from the Atlantic coast (?).

\section{SEMOTILUS, Raf.}

(Leucosomus. Chilonemus. Cyprinus.)

S. corporalis, Mitch. (dorsalis, cephalus, atromaculatus, speciosus, \&c.) Common Chub. Horned Dace.

Body robust; head large; upper jaw protractile; a small barbel on maxillary; dorsal well back on tapering part of body ; scales small and crowded anteriorly; a black spot on base of dorsal ; eye small; dusky blue above; band on side in young; belly whitish (rosy in spring males); dark vertebral line; dusky bar back of opercle; snout coarsely tuberculate in spring males. Length, 10 inches. 
"This, the northern and Susquehanna species, is very seldom met with in the Delaware River, or elsewhere within State limits. It is represented by the next, which may be distinguished therefrom by its much smaller scales. The largest specimens are found in the rivers and large creeks, as the Rancocas. The young generally remain in the smaller, clear-water, rapid rivulets, where they are met with during the spring and summer in abundance."

S. bullaris, Raf. (rhotheus, pulchellus, argenteus.) Rose-colored Chub. Fallfish. Silver Chub. Dace. Roach.

Dorsal nearly above ventrals; scales nearly alike over body; no black dorsal spot; twenty-two scales in front of dorsal ; steel blue above; sides and belly silvery; in spring males rosy below; largest of our eastern Cyprinidoe.

"This very common species was long confounded with the northern species, and was first properly named by Prof. Cope. It is the Delaware representative of the corporalis of the Susquehanna, and the pulchellus of the North. It is, when large, a river-frequenting species, but spawns generally in small brooks, where the young remain until five or seven inches long. It is subject to many variations of color, which is dark or light, according to the character of the water in which they are found.

"Dr. Mitchill described a chub as the atromaculatus, which is generally now considered to be the young of this species.

"The largest chub that the writer has succeeded in procuring weighed three pounds; and this is probably the maximum growth of the species.

"As an article of food they are not much prized, and are sought for only by boys, to whom they afford quite good sport by their readiness to take a hook, if well baited.

"In the river they seem to prefer rocky bottoms and swift water, and in the autumn they follow the schools of perch, as though they sought food that these fish left after them.

" The Lepidosteus, or 'Gar,' feeds principally upon the chub, seizing it about the middle, and frequently cutting it entirely in two, when it catches the two pieces and devours them."[C. C. A.] 


\section{SQUALIUS, Bonap. \\ (Telestes. Clinostomus. Tigoma, \&c.)}

S. funduloides, Grd. (carolinus.) Gold-thread Roach. Rosy Dace.

Teeth compressed, close set, hooked, two-rowed, two teeth in lesser row; teeth without grinding surface; mouth wide and oblique; lower jaw projecting; dorsal fin well backward; head moderate; eye large; dusky above; a dark lateral band below a paler streak; yellowish below, red in spring males.

"This handsome little 'shiner' was found by the writer to be very abundant in the Delaware where the Assanpink Creek enters it; but no specimens were taken in any of the small creeks flowing into the river."-[C. C. A.]

S. margaritus, Cope (Leuciscus). Gold-thread Shiner. Pearly Dace.

Body stout; head blunt; mouth small, oblique; eye large; scales small; fins large; dorsal posterior; dusky olive above; sides silvery; belly white; crimson in spring males. Length, 3 inches; lateral lines, 58. Susquehanna basin.

"Associated with the preceding were several specimens of this allied species, which has been lately discovered and described by Prof. Cope, of Haverford College" (1868).

\section{NOTEMIGONUS, Raf.}

(Stilbe. Abramis, Cyprinus.)

N. chrysoleucus, Mitch. (americanus, versicolor, Leuciscus, Leucosomus, Luxilus, \&c.) Golden Shiner. Bream. Roach.

Teeth one-rowed, serrate, with grinding surfaces; lateral line decurved, continuous; abdomen rounded; belly keeled behind vent; tail not keeled; head small, conic; month small, oblique, without barbels; dorsal fin well back; clear greenish above; sides silvery and gold; fins yellowish, tipped with orange in spring males. Length, 12 inches; anal rays, 13. Has some resemblance to shad.

"The roach is everywhere met with in New Jersey, preferring still waters, with an excessive growth of vegetation upon the bottom of the stream. In these masses of vegetation it conceals itself from the attacks of the pike, which latter feed almost exclusively upon them." 
CARASSIUS, Nils.

O. auratus, L. (Cyprinus.) Goldfish.

Scales large; no barbels; dorsal long, third ray a spine; anal short, with spine; ventrals well forward; olivaceous, orange and variegated in domestication. Length, 12 inches, variable. China and Japan; now naturalized in many of our eastern streams.-J. \& G.

\section{CYPRINUS, L.}

C. carpio, L. European Carp.

Body robust, compressed; mouth with four long barbels; snout blunt; dorsal long (23 rays), with a stout spine; anal short (8 rays), with spine; olivaceous. Length, 18 inches. Domesticated in Europe and America from Asia. Now many varieties. Six-pound carp have been taken in the Delaware, escaped from private ponds.

\section{Order ISOSPONDYLI.}

No interclavicles nor auditory ossicles; gills four, with slit behind fourth; anterior vertebræ distinct; precoracoid, symplectic and parietals present.

\section{Family ALBULIDaz.}

Lady-fishes.

Tail diphycercal; maxillaries help form upper jaw; head naked; dorsal in front of anal; mouth small, horizontal; back of tongue and roof of mouth covered with coarse, pavement-like teeth; body covered with small, brilliant scales; snout shaped like that of a pig; eye large; pseudobranchiæ present; branchiostegals about fourteen; belly flattish and scaled; caudal fin widely forked.

\section{ALBULA, Gronov.}

A. vulpes, L. (Esox, L., conorhynchus, Günth.) Lady-fish. Bonefish.

Brilliantly silvery; olivaceous above, with faint streaks along the rows of scales; upper lobe of caudal the longer; a peculiar 
band of scales along the back. Dorsal rays, 15; length, 18 inches. Cape Cod to tropics, in all oceans. Not of great food value, but beautiful and gamey.

\section{Family ELOPIDE.}

\section{Bigmeyed Herrings.}

Mouth large; teeth all pointed; body with cycloid scales; mouth broad, with lower jaw prominent; branchiostegals twenty to thirtyfive; dorsal little behind ventrals.

\section{ELOPS, L.}

E. saurus, L. Big-eyed Herring.

Body elongate, covered with thin, small, silvery scales ; dorsal fin depressible into a sheath of scales; anal smaller and also depressible. Dorsal rays, 20 ; length, 24 inches. Not rare on Atlantic coast.-J. \& G.

"This is a rare fish along our coast, and only straggling specimens are met with. De Kay reports but a single specimen having been seen by him, which was taken in the harbor of New York."-[C. C. A.]

\section{MEGALOPS, Lac.}

M. atlanticus, Cuv. \& Val. Tarpum. Jewfish.

Dorsal behind ventrals; anal fin larger than dorsal; scales large, except on belly; anal with sheath of scales; uniform silvery; back darker. Dorsal rays, 12 ; anal rays, 20. Atlantic Ocean, entering fresh water. Common southward. Extralimital to New Jersey fauna.

\section{Family CLUPEIDE.}

\section{Herrings.}

No lateral line; body more or less compressed; head naked; jaws equal; maxillaries in three pieces on each side; teeth feeble; pseudobranchiæ present; anal fin long; caudal forked. 


\section{ETRUMEUS, Bleek.}

E. teres, De K. (Alosa.) Round Herring. Slender Herring.

Body fusiform; suout pointed; scales cycloid, deciduous; branchiostegals fifteen; anal small; dorsal in front of ventrals; silvery; olivaceous above ; eye large ; fins small. Dorsal rays, 13.

"This is a rare species of the herring tribe, that occasionally is met with along our coast. The writer found a single specimen at Barnegat ' in the edge of the surf,' as Prof. Baird relates he met with 'a number of specimens' at Beesley's Point. Occasionally it is seen in Delaware Bay."-[C. C. A.]

\section{CLUPEA, L. \\ (Alosa. Pomolobus, \&c.)}

O. harengus, L. (elongata, Le S.) Common Herring. "Whitebait" (young).

Bluish ; silvery below ; body compressed ; scales loose; lower jaw projecting; dorsals in front of middle of ventrals; abdomen serrated in front of and behind ventrals. Dorsal rays, 18. Vomer has an ovate patch of teeth; spawns in sea.

"The herring is very abundant at times, and then will be almost unknown to the coast."

O. mediocris, Mitch. (mattowacca, lineata.) Hickory Shad. Tailor Herring. Fall Herring.

Bluish silvery; sides with faint stripes; head elongate; body more elliptic, less heavy forward; lower jaw projecting; upper emarginate. Dorsal rays, 15 ; anal rays, 21 ; a few teeth on tongue; ventral scutes prominent, $20+16$. Newfoundland to Florida; of little value as a food fish.

"This is not unknown to our coast, but is only met with in small numbers, during the autumn months."

C. vernalis, Mitch. (pseudoharengus, Wils., tyrannus, Stor.) Alewife. Branch Herring. Gaspereau.

Blue above; sides silvery, with stripes; a black spot behind opercle; body deep and heavy forward; head short; lower jaw projects a little, npper emarginate ; eye large; lower lobe of tail fin the longer; dorsal high, 16 rays; anal, 19 rays; ventral scutes, $21+14$. Enters streams to spawn.

"This herring precedes the shad in the Delaware, and is after- 
ward associated with it. It enters the various creeks and many thousands are occasionally taken by nets, in the creeks they have overstocked."

C. æastivalis, Mitch. (A. cyanonoton, Stor.) Glut Herring. Blueback.

Like preceding, but with lower fins and smaller eyes; has peritoneum black; of less value as a food fish; appears later than C. vernalis.

O. sapidissima, Wils. (Alosa, præstabilis, De K.) Common Shad.

Bluish above; sides silvery; a dark spot behind opercle, and sometimes others along line dividing the darker back from the sides; body deep; mouth large, jaws equal, the lower fits into notch of upper; cheeks much deeper than long; fins small; dorsal nearêr snout than base of caudal; no teeth (except a few on jaws, deciduous); preopercle scarcely prolonged anteriorly below. Dorsal rays, 15 ; anal rays, 21 ; ventral scutes, $21+16$.

"The principal shad river in our State is the Delaware, and in this stream they are not now as abundant, nor met with as large as twenty years ago. Many causes have been suggested for the decrease in the yield, and the destruction of the fishery by the erection of dams has been discussed in all its bearings. The diminution of their numbers is dependent, in all probability, upon the marked increase of rockfish, which devour in immense numbers the young shad that in September descend the river to seek winter quarters in the ocean. The attacks of the rockfish also will explain, in a measure, the scarcity of the large specimens occasionally taken, and known as 'brass-backs.'

"The erection of dams above Trenton would not destroy the fisheries if such dams were erected with a 'fish-way' that would enable them to pass up stream, without necessitating them to make an actual leap, which the salmon considers no objection.

"The diminution of the annual catch of shad may also be explained by the prevalence of immense gill-nets in the lower part of the river, which are occasionally so numerous and so completely across the river that it is impossible for any shad to pass them.

"Shad spawn about the 'falls' opposite Trenton, more or less frequently, every summer, but the ova are probably always devoured by the swarms of rockfish and white perch that are ever on the alert for the eggs or the young. The shad appears 
late in February or early in March, according to the weather, and until the end of the season allowed for catching them, they are met with more or less abundantly, going up stream. Above the Delaware Water Gap they are seldom plentifully met with.

"Although not generally credited, the shad in May will take the hook, if attractively baited with maple blossoms or insects. The hook must be floated upon the surface of the water and drawn slowly along. If the line is long, so that the boat the angler is in does not scare them, the hook is pretty sure to be seized if there be any shad "passing up." -[C. C. A.]

The shad-catch from the Delaware is now worth nearly half a million dollars annually. Since the government has begun stocking the river, the increase in the run of shad has been remarkable in spite of rockfish, which are thought to prey on the young shad.-J. N.

\section{OPISTHONEMA, Gill.}

\section{(Clupea.)}

O. thrissa, Osbeck. Thread Herring.

Bluish above, silvery below; an indistinct bluish shoulder spot; scales fixed; each scale on back with a dark spot, forming longitudinal lines; body compressed, oblong; belly serrate; tongue with small teeth; lower jaw slightly projects; dorsal in front of middle, with a filament. Dorsal rays, 19 ; anal rays, 24 ; scutes, $17+14$. Atlantic; mostly southward. Sometimes poisonous.

"Never abundant, but appears annually along our coast in September. Occasionally they enter Delaware Bay, but never come to strictly fresh water."

\section{BREVOORTIA, Gill.}

(Clupea.)

B. tyrannus, Latrobe (C. aurea). Menhaden. Mossbunker. Bonyfish. Whitefish. Bugfish. Yellow-tail. Flat-back.

Fins, head, \&c., comparatively short; dorsal a little behind ventrals; scales strongly serrated, arranged irregularly; bluish above; sides silvery, with brassy luster; fins yellowish; a large shoulder blotch, behind which are often smaller spots. Dorsal 
rays, 19 ; anal rays, 20 ; no teeth; ventral plates, $20+12$; length, 12 to 18 inches. Very abundant on our southern coast; spawns in the sea; the young canned as sardines; adults used for oil and manure.

\section{Family DOROSOMATIDE.}

\section{Gizzard Shads.}

Body short, deep, much compressed, covered with thin, cycloid, deciduous scales; belly sharp edged, serrated; head naked, short; mouth small, inferior, oblique; no teeth; maxillary in two pieces, forming only a small part of jaw; no lateral line; anal fin long and low ; caudal forked; stomach like a fowl's gizzard.

\section{DOROSOMA, Raf.}

(Chatoëssus, Cuv.)

D. cepedianum, Le S. (ellipticus.) Gizzard Shad. Hickory Shad.

Silvery; bluish above; young with shoulder spots; dorsal with last ray filamentous; lower lobe of caudal the longer. Dorsal rays, 12 ; anal rays, 31 ; scutes, $17+12$; length, 15 inches. Abundant along our southern shore. Handsome, but not valuable for food.

"Generally preceding the 'shad' in its passage up the river, this large but worthless species appears in greater or less rumbers, and entering the various creeks, creates quite a commotion among the juvenile fishermen who may chance to come across them. Occasionally the 'gizzard shad' is carried by a freshet into inland streams, usually having very small outlets, and thus imprisoned they thrive very well. A pond near Trenton was in 1857 thus stocked with them, and is now full of specimens, some weighing five pounds apiece. Along the coast they are not abundant, and like the true 'shad,' they appear to come from the South, to spawn in the fresh waters of the northern rivers." 


\section{Family ENGRAULIDIDZE.}

\section{Anchovies.}

Body elongate, somewhat compressed, covered with thin cycloid scales; mouth extremely large, overlapped by the pig-like suout; the maxillary long and slender, extending backwards; premaxillaries small, firmly joined to maxillaries; teeth small, fine and even, in a single row usually; eye large and far forward; pseudobranchiæ present; no lateral lines; belly rounded; size small.

\section{STOLEPHORUS, Lac.}

(Engraulis, Cuv.)

S. browni, Gmel. (vittatus, mitchill, Günth., hiulcus, G.\& B.) Anchovy.

Olivaceous; sides silvery, with a distinct silvery band; snout quite projecting; teeth strong; dorsal nearer caudal than snout; anal with a sheath of scales; belly has a faintly-serrated edge. Dorsal rays, 12 ; anal rays, 20 ; length, 4 to 6 inches.

"This really valuable little fish appears annually along our coast in extensive schools, and is easily taken."

S. mitchilli, Cuv. \& Val. (duodecim, Cope, vittatus, Stor.)

Very pale; translucent; silvery lateral stripe narrow ; snout and caudal yellowish, with many dark points; a stripe of dark points along back; both jaws toothed; cheeks triangular; anal high (26 rays); dorsal over anal (18 rays). Length, $2 \frac{1}{2}$ inches.

"This is not as common as the preceding, which is so very abundant during August and September."

S. perfasciatus, Poey.

Body quite slender; belly not serrated; head not so deep as browni, more pointed; eye small ; maxillary teeth well developed; mandibular ones slender; scales deciduous; lateral silvery stripe broad, bordered above by dusky streaks. Dorsal rays, 12 ; anal rays, 20 ; length, 4 inches. West Indies ; occasional northward.

\section{Family SCOPELIDE.}

Mouth wide; entire margin of upper jaw formed of premaxillaries ; maxillamies small; pseudobranchiæ present ; cheeks and opercles 
commonly scaly ; adipose fin often present ; dorsal of soft rays only; skeleton weakly ossified; air-bladder small or wanting; intestine short; an oviduct present.

\section{SYNODUS, B. \& S. \\ (Baurus, Cuv.)}

S. fœtens, L. Lizard-fish. Soury. Sand Pike.

Teeth on palate in a single row on each side; olivaceous; yellowish below; back mottled; head brownish, vermiculated; inside of mouth yellowish; scales, seven rows on cheek, five on opercle; pectoral fin short, ventrals long; scales cycloid; body nearly terete; head depressed, with triangular pointed snout; premaxillary with knife-like teeth, the inner and large ones depressible; also depressible teeth on tongue. Branchiostegals, 12 ; anal and dorsal rays, 11 ; length, 12 inches. Common southward. Not valued as food.

"Rare. Baird found a specimen in Toms River in 1854."

\section{Family SALMONIDZz.}

Salmonoids.

Body elongate, covered with cycloid scales; head naked; maxillary with supplemental bone, forms part of upper jaw margin ; adipose fin present, caudal forked; pectorals placed low; lateral line present; abdomen rounded; air-bladder large; no oviduct.

\section{OSMERUS, L.}

(Salmo. Atherina.)

O. mordax, Mitch. (viridescens, Le S.) American Smelt.

Transparent greenish above, silvery on sides; some dark points on body and fins; body rather slender; head large, long pointed. with large mouth, having strong, fang-like teeth on tongue and vomer; small teeth on maxillary; other teeth on palatines, \&c. ; mandible projecting; scales deciduous; dorsal fin begins over ventrals. Branchiostegals, 8; dorsal rays, 10 ; anal rays, 15; 
length, 12 inches. (European smelt has larger scales.) Atlantic coast from Virginia northward, entering rivers; sometimes landlocked. Sometimes sold as "frost-fish."

"The Raritan River produces the greater quantity of smelt taken in the State, although they are found in autumn in the Hackensack, Passaic, Hudson and the Delaware. Those found in the Delaware are generally larger, are fewer in number, and are not as highly prized by epicures."

\section{ONCORHYNOHUS, Suckl.}

(Salmo.)

O. tchawytcha, or chouicha, Walb. (quinnat, orientalis.) Columbia River Salmon. Sacramento Salmon, \&c.

Dusky above, silvery below; head darker than body; back, dorsal fin and tail with many black dots; male in October blackish, blotched with reddish; head conic and pointed ; vomerine teeth weak; males in fall have jaws elongated and hooked, with large anterior teeth; color darker and body deeper at shoulders; flesh red, paler in fall at breeding season. Dorsal rays, 11 ; anal rays, 16 ; length, 36 inches. Introduced into eastern rivers, attain a weight of 16 to 18 pounds, in California much more; move up river in summer, often a great distance. $30,000,000$ pounds are taken yearly in the Columbia River. The Raritan and Delaware Rivers (and tributaries) were stocked with 235,000 of the fry of this species by Dr. J. H. Slack, in 1874, but have not flourished, though specimens have been seen occasionally (?).

\section{SALMO, L.}

S. salar, L. (sebago, gloveri.) Common Atlantic Salmon.

Body symmetrical; head low; scales comparatively large, silvery and well imbricated in young, becoming imbedded in adult males; back brownish; many black spots on sides of head, body and fins; red patches in males; the young ("parrs") with eleven dusky cross-bands besides red patches and black spots. Bands, 11 ; dorsal rays, 11 ; anal rays, 9. Anadromous, with vomerine teeth little developed; breeding males with lower jaw hooked upwards; upper jaw emarginate. Var. sebago applied to land-locked forms. 
"The Delaware River no longer produces salmon, but the occasional capture of an isolated specimen, warrants the addition of this species to our list of the State's ichthyic fauna. Three several endeavors have been made to 'plant' the salmon in the Delaware, but without success, which cannot be well accounted for, as the water generally is very clear from Trenton upwards, and trout, are not unfrequently met with" (1868).

The Delaware, the Raritan and the Passaic have been re-stocked (1874), with similiarly unfavorable results, as in case of preceding species. The water is claimed to be "too muddy."

S. fontinalis, Mitch. (immaculatus, canadensis, hudsonicus.) Brook Trout. Speckled Trout.

Live in fresh water nearly permanently; mouth and eye large; red spots on sides; back mottled with dark patches; dorsal and caudal fins barred; belly in males often red. Var. canadensis refers to specimens that run to sea-" salmon trout"which then are plain silvery. Many local varieties. Dorsal rays, 10 ; anal rays, 9 ; length, 18 inches.

"The mountain streams in the northern portions of the State generally abound in trout, and those brooks that empty directly into the Delaware, in Sussex county, produce very large specimens, which latter are found in the river in midsummer, near the mouths of the small streams."

\section{Family PERCOPSID}

Lateral margins of upper jaw formed by the premaxillaries bearing villiform teeth; mouth small; bones of head cavernous; scales, ctenoid. Branchiostegals, 6 ; dorsal rays, 11 ; anal rays, 8.

\section{PERCOPSIS, Ag.}

P. guttatus, Ag. Trout Perch.

Pale olivaceous, with silvery stripe along lateral line; obscure dots or spots above; head slender and conical. Length, 6 inches. Spawns in spring. Delaware River, northward and westward. 


\section{Order HAPLOMI.}

No precoracoid nor interclavicles; mouth with teeth; ventral fins abdominal; no adipose fin; symplectic present; parietals separated by the supra-occipital; scapular arch attached to cranium.

\section{Family CYPRINODONTIDza.}

\section{Toothed Minnows.}

Margin of upper jaw formed by premaxillaries only, freely protractile; vent abdominal ; body depressed behind, compressed forward, covered with large cycloid scales; no lateral line; head scaly; no pseudobranch; caudal fin not forked; sexes usually unlike; fins largest in males; many are ovoviviparous.

\section{GYPRINODON, Lac.}

(Lebias, Cuv.)

C. variegatus, Lac. (ovinus, bovinus, eximius.) Mummichog. Killiefish.

Oviparous; intestine short; carnivorous; teeth incisor-like, notched, in one row ; body stout; dorsal rays, 10 ; back arched; male dusky, traces of bars; caudal, dusky bar at base; tips of dorsal and anal dusky; scales with small tubercles in breeding season; female olivaceous; sides silvery, with dark bars, \&c.; a dark spot on dorsal; caudal as in male; dorsal fin behind ven-

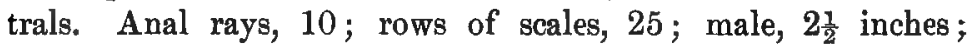
female, $1 \frac{1}{2}$ inches. Brackish water.

"This little fish is abundant everywhere, where there is sufficient salt water to sustain them. They wander about in large schools, and are of little value." 


\section{FUNDULUS, Lac. \\ (Hydrargyra. Xenisma.)}

F. majalis, Walb. (Esox flavulus, Cobitis.) Mayfish. Large Killifish. Rockfish.

Teeth pointed, in bands; dorsal begins in front of anal; branchiostegals six; mouth very oblique; anal very high in males; black cross bars and black dorsal patch in males; females with longitudinal black stripes; size larger than males. Dorsal rays, 12 ; anal rays, 10 ; length, 5 to 6 inches. Largest of our Cyprinodonts; 36 scales in length (along lateral line).

"This is a very common species in the various bays, but is not so numerous as the following."

F. ewampinus, Lac.

A southern variety of preceding, with scales a little smaller; color greenish olive, with silvery longitudinal band and twelve to fifteen vertical blackish streaks. Dorsal rays, 14 ; anal rays, 12 ; in lateral line, 43 scales.

"This abundant species is met with along our coast generally, especially along the beach and at the inlets. It goes in large schools, and does not associate much with other species."

F. diaphanus, Le S. (multifasciata.) Spring Minnow.

Body slender; head flat above; fins not large; olivaceous, with sides silvery; fifteen to twenty-five black cross bars; back spotted with black; fins plain; outer teeth not much enlarged. Dorsal rays, 13 ; anal rays, 11 ; lateral line, 40 scales; depth, 12 rows; length, 4 inches.

"This species is abundant in the rivers generally, and in many creeks."

F. nigrofasciatus, Le S.

Body short and deep; snout obtuse; anal fin short; fins immaculate; males with nine to ten silvery cross bars; female with nine to ten black bars. Dorsal rays, 10 ; anal rays, 9 ; length, $2 \frac{1}{2}$ inches. With next, not common.

F. heteroclitus, L. (Esox, pisculentus, zebra, grandis, floridensis.) Common Killifish. Mummichog. Salt-water Minnow.

Body thick set; back elevated, broad in front; head blunt, flat on top; dorsal further back in female, opening of oviduct 
near tip of anterior ray of anal; teeth in broad bands; males dull green; belly yellow; sides with silvery spots and bars; vertical fins dark, with pale spots; dorsal with dark spot; anal and ventrals and under part of head yellow; young males with dark bars; females plain olivaceous, lighter below. Dorsal rays, 11 ; anal rays, 11 ; scales, $36 \times 13$; length, 3 to 5 inches. Grandis is a larger southern variety, and pisculentus has wider head. Most abundant of Cyprinodonts for United States.

"This is not a very abundant Cyprinodont. It is found associated with allied species. They have no habits peculiar to themselves."

ZYGONEOTES, Ag.

(Micristius.)

Z. cingulatus, Cuv. \& Val. (Fundulus, Hydragyra, Haplochilus, luciæ.) Top Minnow.

This genus differs from the preceding in the smaller size, dorsal farther back and smaller; swim on the surface and feed on insects (not exclusively); body short and deep; anal larger than dorsal ; ten to twelve vertical dark bars on sides; a black behind a white spot on dorsal ; other fins immaculate. Dorsal rays, 8 ; anal rays, 9 .

"Prof. Baird discovered this species at Beesley's Point. It proves to be quite common in the brackish waters of the State, generally."

\section{LUOANIA, Grd.}

L. parva, Bd. \& Grd. (Cyprinodon.) Little Killifish, or Top Minnow.

Elongated; head less than one-fourth the length ; female plain light olive; male, dorsal and caudal bright yellow; anal orange and each margined with black; dorsal with black spot at base. Dorsal rays, 11 ; anal rays, 9 ; rows of scales, 26 to 28 ; very small.

"This species was first made known to naturalists by the description of Baird, who distinguished its specific characters as distinct from the preceding, from specimens taken at Beesley's Point." 


\section{Family UMBRID E.}

\section{Mud Minnows.}

Carnivorous; live in mud or among weeds; mouth small ; teeth villiform and equal; lower jaw the longer ; scales cycloid, cover head also; caudal fin rounded.

\section{UMBRA, Müll.}

(Melanura, Ag.)

U. limi, Kirt. (annulata, pygmæa.) Mudfish. Dogfish. Mud Minnow. Mud Dace.

Dark brown, with white longitudinal streaks, sometimes with cross bars; a black bar at base of caudal; head rather large. Dorsal rays, 13 ; anal rays, 7 ; rows scales, $35 \times 15$; length, 2 to 4 inches; no lateral line; bars, 6 . Eye small; anal shorter than dorsal; mucous pores on preopercle.

"Found in the streams of the State, except in very rapid water."

\section{Family ESOCID E.}

\section{Pikes.}

Head long, with long snout; mouth large, with long cleft, lower jaw the longer; maxillaries form most of margin of upper jaw ; premaxillaries, \&c., have broad bands of cardiform movable teeth; lower jaw with strong teeth of different sizes; a band of small teeth on tongue; head naked above; scales small.

\section{ESOX, L.}

Đ. americanus, Gmel. (lucius, niger, fasciatus, ornatus.) Banded Pickerel. Trout Pickerel. Pike.

Cheeks and opercles scaly; body robust; head heavy; snout blunt and short; eye large; dark green, with twenty blackish, curved bars; a bar below eye. Bars, 12 to 13 ; dorsal rays, 11 ; anal rays, 11 ; lateral line, 105 scales; length, 12 inches. 
"This species is generally looked upon as the same with $E$. reticulatus, although so very dissimilar in its markings, and uniformly smaller size. This pike is very generally associated with the reticulatus, and in all its habits is identical. The smaller specimens are generally found in small streams and ditches, with the true 'ditch pike,' feeding on the swarms of small fish that frequent such waters to avoid the attacks of the yellow and white perch. They appear to be uniformly abundant throughout the State, specimens being found in the streams of every county, including Cape May county, where they are met with in abundance and of large size."

Var. porosus, Cope (cypho). Hump-back Pickerel. Ditch Pike.

Has a more arched back, \&c.; sometimes confused with $E$. umbrosus, the "little pickerel," which has body moderately stout; eye large; color greenish gray, with curved bars or reticulations, variable ; a dark bar downward from eye and one forward. Dorsal rays, 11 ; anal rays, 11 ; lateral line, 105 scales; length, 12 inches. Mississippi Valley. Extra-limital to New Jersey.

"This small pike prefers small ditches with overhanging banks, yet that have a steady, gentle flow of pure, cool water. In its habits generally it resembles the preceding, and not unfrequently is met with in waters abounding in the larger species. It appears, from the author's observation, to prey principally upon the 'mud minnow,' which is itself a ravenous, pikeresembling species. It is not as abundant as the foregoing or the succeeding, and has been found by the writer only in Mercer county."-[C. C. A.]

E. lucius, L. (estor, boreus, deprandus.) Great Lake Pike. Northern Pickerel.

Lower half of opercle bare; light spotted on a darker ground in rows; color greenish gray or bluish gray; black spots on fins. Bands, 15; dorsal rays, 17; anal rays, 14; lateral line, 123 scales; length, 2 to 4 feet. Common in the East and Great Lake region. Not found in Atlantic coast system of rivers.

Đ. reticulatus, Le S. (affinis.) Green Pike. Common Eastern Pickerel.

Head prolonged; snout long; eye small ; caudal well forked; green, with golden luster on sides, marked with dark lines and 
streaks, mostly horizontal, producing a reticulated effect; fins plain ; a dark band below eye. Bands, 15; dorsal rays, 14 ; anal rays, 13 ; lateral line, 125 scales; length, 2 feet.

"This fine fresh-water fish is abundant throughout the State, inhabiting pretty much every stream and pond, avoiding rapid currents, and delighting in still, deep waters, with a sufficient growth of spatter-dock to conceal them from the sun's rays and general observation, while they lie in wait for any unlucky minnow, shiner, roach or chub that may approach within a limited number of feet of them."

\section{Order APodes.}

(ENCHYLYCEPHALI. HOLOSTOMI. COLOCEPHALI.)

Eels.

Scapular arch free from cranium ; no precoracoid; no ventral fins ; increased number of vertebræ; no pseudobranchiæ.

\section{Family ANGUILLID Za.}

Eels.

Body serpent shaped; head conical ; maxillaries wanting or united with premaxillaries; gill openings separate. Includes more than the Anguillidce of Günther.

ANGUILLA, Thun.

(Muræna, L.)

A. rostrata, Le S. (tenuirostris, bostoniensis, tyrannus.) Common American Eel.

Tongue free anteriorly; pectorals present; body with small scales; lower jaw projecting; teeth in bands; head pointed and not short; dorsal one-third of length from snout; distance from front of anal to front of dorsal about equal to length of head; pectoral shorter than mandible; color brown, with yellowish tinge. Length, 50 inches. 
"This, the 'common eel,' is abundant everywhere, and seems equally at home in the rivers and small rivulets, with scarcely sufficient water to cover them."

A. vulgaris, Raf. (acutirostris, Risso.) European Eel.

Distance from snout to dorsal less; from anal to dorsal more; head shorter, and pectoral as long as mandible. Accredited by Günther to New Jersey.

LEPTOCEPHALUS, Gmel.

(Conger. Muræna.)

L. conger, L. (niger, vulgaris; C., occidentalis and Isognatha oceanicaAbbott's Catalogue.) Conger Eel. Sea Eel.

Jaws equal; skin scaleless; lateral line present; gill openings large ; short patch of teeth on vomer ; dorsal close behind pectorals; cleft of mouth deep; pectorals one-third as long as head. Length, 4 to 8 feet; darker above than $A$. rostrata.

"This sea eel is not abundantly met with anywhere along our coast." :

\section{SIMENOHELYS, Gill.}

S. parasiticus, Gill. (A. macrocephala-Abbott's Catalogue.) Bullheaded Eel (?). Pug-nosed Eel.

Differs in having head blunt at snout; gill opening very short; teeth rounded, none on vomer, \&c.; buries in flesh of halibut. New Foundland banks. It is doubtful if following refers to this and not to a variety of one of preceding.

"Occasionally a heavy-headed species of eel is taken in the Delaware River and brought to the markets. A specimen of this description was purchased by the writer in Trenton market in August, 1865."-[C. C. A.] 


\section{Section PHYSOCLISTI.}

No open connection between gullet and air-bladder; ventral fins near head, often spined; other fins usually spiny; premaxillaries normally form the entire border of upper jaw.

\section{Order Synentognathi.}

Scapula united to cranium by a post-temporal bone ; lower pharyngeal's united; fins without spines; ventral fins abdominal; no interclavicle ; no distinct supraclavicle. ,

\section{Family SCOMBEROSOCID $z$.}

Garfishes and Flying-fishes.

With cycloid scales; lateral line low; head scaly; premaxillaries not protractile; pectorals inserted high; lower lobe of caudal the longer; nostrils large and near eye; air-bladder large ; carnivorous.

\section{TYLOSURUS, Cocco.}

(Belone, Cur.)

T. marinus, Bl. \& Schn. (B. truneata, longirostris.) Garfish. Billfish. Needle-fish.

Jaws prolonged, forming a beak, with sharp, wide-set teeth ; body slender ; scales small, deciduous; bones green ; one ovary ; color green above, silvery below; a silvery lateral stripe; a dark spot above root of pectorals; head flat above, not rugose ; caudal not cleft. Dorsal rays, 15 ; anal rays, 18 ; length, 4 feet.

"This interesting species is more or less abundant in the principal rivers of the State. In the Delaware they are numerous, and entering the Delaware and Raritan Canal at Bordentown, find their way into the basins, where they are left in winter when navigation is closed and the water in the canal is drawn off." 
SCOMBERESOX, Lac.

(Sayris, Raf.)

S. saurus, Walb. (scutellatum, Le S.) Billfish. Saury. Skipper.

Jaws form a beak, with feeble teeth; lower jaw longer; pectorals and ventrals small; dorsal and anal with finlets; size small, eighteen inches; air-bladder large; color olive brown above, bordered sharply by silvery band; silvery below; head broad above, narrow below, tapering to slender, and pointed beak ; caudal forked.

"Occasionally a specimen of this species is caught in the bays, but it does not appear to ever have been abundantly met with."

\section{HEMIRHAMPHUS, Ouv.}

H. unifasciatus, Ranz. Half-beak.

Upper jaw short; lower prolonged to beak, red at tip; scales large, deciduous; large plates on head; color greenish, with narrow silvery band. Dorsal rays, 14 ; anal rays, 15 ; length, 12 inches. Common southward; run in schools. Cape Cod to Panama and eastward.

\section{HALOCY PSELUS, Weinl.}

H. evolans, L.

Much like next, but with smaller pectorals; olivaceous above, with specks; silvery blue below, pectorals black, with lower border whitish. Dorsal rays, 13 ; anal rays, 13 ; 20 scales in front of dorsal. Spawns on Atlantic coast in summer. Not common.

\section{EXOCGTUS, L.}

F. rondeletii, Cuv. \& Val. Flying-fish.

Head blunt; mouth small; teeth feeble; eyes large; scales large, deciduous; no finlets; caudal widely forked; pectorals very long, serving as organs of flight, not by flapping, but as parachutes, the motion having been acquired by strokes of tail before leaping from the water. This species has black ventrals. Dorsal rays, 11 ; anal rays, 11. 
E. noveboracensis, Mitch. Flying-fish.

Dark blue above; pectorals blackish at tip; ventrals white. Dorsal rays, 14 ; anal rays, 9. More common than preceding.

"This species can only be looked upon in the light of a straggler. A specimen, taken at Beesley's Point, is in the museum of the Academy of Natural Sciences, at Philadelphia."

E. exiliens, Gmel. Flying-fish.

Ventrals nearly plain; head not very blunt. Dorsal rays, 11 ; anal rays, 12. Young with five broad transverse bars; pectorals banded; body very slender. E. exiliens was originally applied to the young, E. melanurus to the adults of this species. Occasional on our coast.

\section{CYPSELURUS, Swains.}

C. furcatus, Mitch. (nuttallii.) Double-bearded Flying-fish.

Size small, with two ribbon-like barbels; young with three bands on belly ; pectorals marbled with black; dorsal very high. Dorsal rays, 13 ; anal rays, 9.

"This species is not unfrequently seen, but is by no means abundant."

c. comatus, Mitch. Single-bearded Flying-fish.

Greenish above, paler below; ventrals dusky; eye very large ; barbel very long, with small accessory barbels at its base. Dorsal rays, 12 ; anal rays, 9 ; length, 8 inches. Rare.

"This may be an occasional visitor to our waters, but very rarely does it appear, if at all."

\section{Order lophobranchil.}

Gills in tufts ; no superior branchihyals, pharyngeals or basihyals ; post-temporal co-ossified with cranium; snout produced, having a small, toothless mouth at end; opercle one plate; skin with bony plates; no ventrals. 


\section{Family SYNGNATHIDE.}

Pipefishes.

Body long and slender; snout tube-like; gill openings reduced to a small aperture; tail long, with small caudal; males with egg pouch below tail or on abdomen.

\section{SIPHOSTOMA, Raf.}

(Syngnathus.)

S. fuscum, Stor. (peckianus, fasciatus, \&c.) Common Pipefish.

Body six or seven angled, not compressed; tail long; anals minute; lower jaw projecting; breast shields not covered by skin; sides blotched; muzzle shorter than rest of head; dorsal rays, 35 to 40 , fin covering $4+5$ rings; length, 10 inches.

"This is not common in New Jersey, but has been met with in the Hackensack, Passaic and Raritan Rivers. It is much more common in the Hudson."

\section{Family HIPPOCAMPIDE.}

\section{Sea Horses.}

With tail prehensile, without caudal fin; head at right angles to body axis, horse-like in appearance; body compressed; held vertically in water.

\section{HIPPOOAMPUS, Raf.}

(Syngnathus.)

H. heptagonus, Raf. (brevirostris, lævicaudatus.) Mediterranean (?) Sea Horse (antiquorum).

Body has tuberculated rings; head with occipital erest; neck curved; egg pouch a sac at base of tail in male; color yellowish brown, with radiating brown lines on cheeks; white band across snout; sides with pale spots (in European specimens, not in American); some of tubercles on back longer than intermediate ones; crest high, with five tubercles and filaments. Dorsal rays, 18 ; anal rays, 4 ; length, 5 inches. Rare. 
B. hudsonius, De K. Common Sea Horse.

Dusky, without spots, but with gray blotches, some on neck, \&c., the most distinct forms an hour-glass figure, extending down each side of back; spines short and blunt, those on head cirrated and weak. Dorsal rays, 19.

"This species is abundant in the brackish waters of the State, but appears to be less so as we proceed south."

\section{Order hemibranchII.}

Ventral fins abdominal; superior branchihyals and pharyngeals reduced in number; mouth bounded by premaxillaries only; shoulder girdle and skull differ from ordinary Acanthopteri, with which they are often classed; gills pectinate.

\section{Family FISTULARIID}

Trumpet-fishes,

Body long, slender, depressed; no scales; bony plates present in skin; head very long, with long, tubular snout, terminating in a narrow mouth; both jaws with minute teeth; tube capable of dilation ; dorsal without spines, behind ventrals; caudal forked, with middle ray produced into a filament; vertebræ numerous.

FISTULARIA, L.

(Solenostomus-Abbott's Catalogue.)

F. tabaccaria, L. Trumpet-fish. Pipefish.

Reddish brown, with blue spots; lower jaw longer. Dorsal rays, 14; anal rays, 13 . Tropical. Occasional northward.

"Has been seen in our waters, but is very rare."

F. serrata, Cuv. Pipefish.

Skin without dermal plates; grayish; head silvery below; blue spots along back and sides; much like preceding, but broader and more depressed; edges of snout serrated. Dorsal 


\section{GEOLOGICAL SURVEY OF NEW JERSEY.}

rays, 14; anal rays, 13. Rare northward. Perhaps same as preceding.

"This species has also been met with, but very rarely. Northward and to the south they are more frequently seen."

\section{Family GASTEROSTEID}

Sticklebacks.

Head long, but no tubular snout; teeth sharp, in a narrow band, none on vomers; premaxillaries protractile; suborbital plate large; branchiostegals three; no true scales, only bony plates; dorsal with two or more spines; anal and ventral fins with spine; build nest for young, which is defended by male. Destroy eggs and fry of other fishes!.

GASTEROSTEUS, L.

(Pygosteus, Brev.)

G. pungitius, L. (occidentalis, dekayi.) Nine-spined (Many-spined) Stickleback.

Olivaceous above, punctate and barred; silvery below; body slender, compressed, tapering to slender, keeled tail; skeletal plates not all covered by skin; snout blunt; anal spine larger than dorsal. Anal rays, 8 ; length, 3 inches.

"Not an uncommon species in the streams of the State flowing into salt water. The writer has met with them at Trenton."[C. C. A.] The following note concerns a variety of this species:

"Pygosteus dekayi.

"Not an uncommon species, resembling in habits the above". (G. pungitius).

G. biaculeatus, Shaw. Two-(Three)-spined Stickleback.

Body mailed; tail naked, not keeled ; male blackish in spring, with coppery luster; body short and deep. Soft rays of dorsal, 12 ; of anal, 9. Northern; probably a variety of next.

"This is a common species about Toms River, and is found in the Delaware River at Philadelphia." 
G. aculeatus, L. (noveboracensis, biaculeatus, niger, trachurus, \&c.) New

York Stickleback. Burnstickle. Common Stickleback.

Dark greenish above; sides yellowish; ventrals often red; head long; tail keeled and slender; dorsal spines hinged to plate; large naked area in front of pectorals. Thirteen rays and three spines in dorsal; nine soft rays in anal. Length, 4 inches.

"This is an abundant species, met with along the coast generally."

\section{APELTES, De K.}

A. quadracus, Mitch. Four-spined Stickleback.

Back elevated ; tail very slender, not keeled; skin naked; ventrals, when depressed, enclosed by bony ridge ; free dorsal spines three, directed to different sides, first longest; brownish olive; mottled; silvery below; male nearly black; ventrals red in spring. Length, $1 \frac{1}{2}$ to $2 \frac{1}{2}$ inches; 11 soft rays in dorsal ; 8 in anal.

"This species appears, from the writer's investigations, to be the most abundant species of the five. He has taken it in small streams in the interior of the State, at considerable distance from the river, and fully one hundred and fifty miles from the ocean."-[C. C. A.]

\section{Order ACANTHOPTERI.}

\section{Sping-rayed Fishes.}

Maxillary distinct from premaxillary, which latter forms boundary of mouth; bones of jaws separate, and cranium normal. The most extensive order of fishes, sometimes including also the Hemibranchii, Opisthomi and Pediculati; or sometimes more restricted, the Atherinidce and Mugilidoe being classed as Order Percesoces; and the Gadido, Lycodida, Ophidiidoe, Ammodytidoe and Fierasferidce forming the Order Anacanthini. By some authors (European), the Anacanthini also include the Synentognathi and Heterosomata: the group being considered to include fishes with no spines in dorsal and ventrals, the latter being jugular in position. 


\section{Family MUGILID ż.}

\section{Mullets.}

Body oblong, compressed; covered with large cycloid scales; no lateral line; month small; teeth feeble; premaxillaries protractile; gill openings wide; branchiostegals five or six; pseudobranchiæ large; two dorsal fins, the first with four spines; three anal spines; ventrals abdominal; caudal forked; vertebræ twenty-four; feed on mud.

\section{MUGIL, L.}

M. albula, L. (lineatus, plumieri.) Striped Mullet. Spotted Mullet.

Head large and blunt, scaled; mouth small; jaws toothless, but cirrated; gizzard connected with stomach; body subterete; dark bluish above; sides silvery, with stripes; a dusky patch at base of pectorals; scales medium; eight soft rays in dorsal or anal; scales, $42 \times 13$. Valued as a food-fish where abundant (South).

"This species is not as numerous as the following. Specimens have been found in Delaware Bay, near the ocean."

M. brasiliensis, Ag. (petrosus, lineatus.) Liza. White Mullet. Rock Mullet.

Scales larger; no stripes; body compressed; dorsal and anal partly scaled; nine soft rays in anal.

"Never abundant along our coast, although annually appearing in August and September, and a few remain through the winter."

\section{Family ATHERINIDa.}

\section{Silversides.}

Carnivorous, with feeble teeth and with more than twenty-four vertebræ; no lateral line; scales cycloid, not large; spines flexible; branchiostegals five or six. 


\section{MENIDIA, Bonap.}

(Argyrea. Labidesthes.)

M. notata, Mitch. Silversides.

Premaxillaries protraetile, broad posteriorly, with curved edge, with filiform teeth in a band, none on vomer; lower jaw short; color transparent green, with a lateral silvery band as wide as the large eye; first dorsal of four spines; second with one spine and eight soft rays; anal, one spine and twenty-three rays. Length, 5 inches.

"An abundant species found everywhere along our coast, both in the open sea and the many bays and inlets."

\section{Family SPHYR ENID正.}

\section{Barracudas.}

Ventrals abdominal ; dorsals well separated ; vertebræ twenty-four ; body subterete, with small cycloid scales; head pike-like, scaly; jaws large, lower projecting; large, sharp teeth present; air-bladder forked in front; lateral line well developed; branchiostegals seven; first dorsal of five stout spines.

\section{SPHYRAFNA, Bloch.}

S. spet, Haüy (borealis, vulgaris). Barracuda.

Olivaceous; silvery below; dusky blotches above in young; body slender, with rather large scales; first dorsal inserted some way behind end of pectorals; nine soft rays in second dorsal; anal, 1 spine, 9 soft rays. Length, 24 inches.

"This small fish is generally to be met with in the small streams of the coast counties of the State. There is nothing of interest connected with it, its numbers not making it noticeable except to the collector."

8. guaguanoho, Cuv. \& Val.

Differs from preceding in having first dorsal farther forward. Anal, 2 spines and 8 rays; length, 18 inches. Probably the species referred to in remarks appended to preceding. 


\section{Family AMMODYTIDZZ.}

\section{Sand Launces.}

Scales small, cycloid; head long; mouth large; no teeth; gill openings very wide; pseudobranchs large; premaxillaries very protractile; spinous part of dorsal nearly absent; soft part extends along nearly whole of back ; no ventrals ; no air-bladder; size small ; swim in schools and often bury in sand.

\section{AMMODYTES, L.}

A. americanue, De K. Sand Launce (or Lance). Sand Eel. Lant.

Body lanceolate, with twenty-five transverse, oblique folds of skin having cross series of small cycloid scales between them; a fold of skin along each side of belly; color olivaceous above, silvery below; sides with a steel-blue stripe. Dorsal rays, 60 ; anal rays, 28.

"This curious fish is not unfrequently met with in our waters, but does not appear to be abundant at any time."

\section{Family ECHENEIDID}

\section{Remoras.}

Body fusiform, with minute cycloid scales; mouth wide, with villiform teeth on jaws, vomer, \&c.; premaxillaries not protractile; lower jaw projects beyond upper; spinous dorsal modified into a sucking disk on top of neck, by which the fishes attach themselves to floating objects; ventrals thoracic; no air-bladder.

\section{FOHENEIS, L.}

E. naucrates, L. (albicauda, lineata, holbrooki, \&c. Refer to varieties with long disk and twenty-one laminæ, \&c.) Pegador.

Body slender; thirty vertebræ; brownish; belly like back; sides with a black stripe edged with white; tail fin black, whitish at outer angles; other fins black, with white edges; lower jaw 
with flexible tip; disk with twenty-one to twenty-six laminæ. Soft rays, 32 to 41 ; in anal, 32 to 38 .

"Echeneis naucrates. Indian Remora.

"It is doubtful if this species has been met in the waters of New Jersey.

"Echeneis albicauda. White-tailed Remora.

"The more usually met with of the three species. Specimens have occasionally been met with in the Delaware, at Philadelphia." A variety, only, of $E$. naucrates.

E. remora, Gill. (Remora squalipeta, Dald., jacobcea.) Remora.

Body robust; vertebræ twenty-seven; dorsal rays twentythree, with eighteen lamellæ in disk; tail compressed; head broad; tip of lower jaw not produced. Anal rays, 25. Usually found attached to sharks. Color uniform dark brown.

"This is a less species, less frequently met with than the preceding. In its habits it is identical."

E. (or Remora) brachyptera, Lowe. Fourteen-laminated Remora.

Uniform light brown, with paler fins; disk shorter than base of dorsal, rather broad, with fourteen to sixteen laminæ; upper jaw angular. Dorsal rays, 30 ; anal rays, 26. Warm seas north to Massachusetts.

\section{REOMBOOHIRUS.}

R. osteochir, Cuv. (E. tetrapturorum.) Stiff-finned Remora.

Pectoral fins short, broad, with flat, broad rays ossified and stiff, otherwise like preceding, except paler under head; mouth larger; disk broader and rougher, extending forward over tip of snout, and with sixteen lamellæ. Dorsal rays, 21 ; anal rays, 20. West Indies to Cape Cod. Parasitic on species of Tetrapturus.

\section{Family ELACATID \\ Crab-eaterg.}

Body fusiform, with small, smooth scales; head broad, pike-like; mouth wide, with bands of short, sharp teeth on jaws, vomer, palatines 
and tongue; first dorsal of eight spines; two anal spines; ventrals thoracic; no air-bladder; caudal forked; branchiostegals seven; vertebræ more than twenty-four.

\section{ELACATE, Cuv.}

Đ. canada, L. (atlanticus, niger.) Crab-eater. Cobia. Sergeant-fish. Snooks. Ling.

Olive brown, with broad, dark band on sides, bounded above and below by an indistinct band; below silvery; head much depressed; pectorals falcate; upper lobe of caudal a little the longer; lateral line wavy and irregular. Dorsal rays, 26 ; anal rays, 25 ; length, 60 inches.

"A very rare fish, that occasionally is met with on our coast, and in Delaware Bay."

\section{Family XIPHIID}

\section{Swordfishes.}

Large fishes, with upper jaw much prolonged to form the "sword;" teeth small or wanting; dorsal fin, in adults, in two parts, the anterior the larger; anal similarly divided ; candal widely forked ; air-blander and pseudobranchiæ present; branchiostegals seven. Young differs from adults in having both jaws prolonged to form a beak, in having dorsal fins high and continuous, and in having spines on head.

\section{XIPHIAS, L.}

X. gladius, L. Swordfish.

Teeth none (except in young); ventrals none; anterior dorsal above gill openings, high and falcate, the second small and above the second anal; skin naked (rudimentary scales in young); pelvic arch obsolete; color dark blue above, dusky below; "sword" nearly black above. Dorsal rays, $40+4$; anal rays, $18+14$; vertebræ, $14+12$. Often attain a large size, and are valuable for food.

"On the coast of New Jersey this interesting species is not abundant ever, although more numerous during some years than 
others. Specimens have been seen by the writer taken at Barnegat and Atlantic City. They were all small, the largest measuring about four feet." - [C. C. A.]

\section{TETRAPTURUS, Raf.}

T. indicus, Cuv. \& Val. (albidus, herschelii, brevirostris.) Spearfish. Billfish, \&c.

With small teeth; ventrals represented by spines; dorsals low; skin with rudimentary scales; double caudal keel ; sacculated air-bladder; caudal fin forked at seventy-five degrees; color dark blue above, whitish below; fins like back. Dorsal rays, III $+39+6$; anal rays, II $+13+6$; length, 7 to 8 feet. Not rare on our coast from Cape Cod to West Indies.

\section{Family TRICHIURIDIE.}

Hair-tails.

Ventrals thoracic, imperfect; body very long, compressed and naked; mouth wide and toothed; dorsal long, low, continuous, and with equal and similar rays.

\section{TRICHIORUS, L.}

(Lepturus, Art.)

T. lepturus, L. (argenteus.) Hair-tail. Silver Eel. Ribbon-fish. Silver-fin, \&c.

Tail tapers to a fine point; four barbed teeth in upper jaw ; lower jaw longer; vertebræ, $39+120$; color silvery; ventrals absent in adult; snout pointed. Dorsal rays, 135 ; anal rays, 100. "This is not a common species, though more frequently met with during some years than others. A specimen, measuring twenty-two inches, was captured by the writer at Barnegat, in November of 1862, and others have been seen from Cape May and Atlantic City."-[C. C. A.] 


\section{Family SCOMBRIDas.}

\section{Mackerels.}

Body not much compressed, covered with minute cycloid scales (or naked); head conical; jaws with sharp teeth; dorsal fins two, the first of weak spines depressible in a groove; tail slender, keeled; caudal fin falcate; ventrals thoracic; vertebræ more than twenty-five.

\section{SCOMBER, L.}

S. pneumatophorue, Delar. (grex, delcayi, colias?* \&c.) Chub Mackerel.

Fall Mackerel. Easter Mackerel. Tinker Mackerel.

Body fusiform ; two small keels on each side of tail ; one row of slender teeth in jaws; first dorsal of nine slender spines; quite a space in front of second, which is followed by a series of five finlets; anal similar; color blue, with twenty wavy, blackish streaks and reticulations, enclosing pale blue spots; silvery below. Lateral line, 200 scales; length, 1 foot.

"Quite abundant on the coast during October and November. Straggling specimens occasionally met with in the bays and inlets."

S. scombrus, L. (vernalis.) Common Mackerel.

Lustrous dark blue above, with thirty-five wavy streaks; silvery below; base of pectorals dark; snout long, pointed; ventrals and pectorals short. Length, 18 inches.

"This well-known species is quite abundant during the fishing season on the banks off Barnegat, where they were caught by the writer in 1862." - [C. C. A.]

\section{AUXIS, Ouv.}

A. thazard, Lac. (rochei, vulgaris, bisus, \&c.) Frigate Mackerel.

Body plump, naked behind ; small scales anteriorly; a "corselet" of large scales in pectoral region; mouth small; teeth small ; tail slender, with large keel on each side; seven to ejght finlets behind second dorsal and anal; vertebræ thirty-nine,

*S. colias is the Spanish mackerel of Europe, which has been introduced upon our coast by the U. S. Fish Commission. This has a longer head, lower dorsal fin; the dark bands are narrower and belly is not immaculate. May be considered as a distinct species rather than a variety. 
modified as in Euthynnus; variegated blue and darker; belly silvery; an Old-World fish lately become abundant upon our coast, but of little value for food.

\section{SCOMBEROMORUS, Lac.}

S. maculatus, Mitch. (dekayi.) Spanish Mackerel. Spotted Mackerel.

Body elongate, without a corselet; head pointed and short; teeth knife shaped; fourteen to eighteen feeble spines in low first dorsal, white at base; soft dorsal short, followed by eight to nine finlets; anal similar; ventrals small; vertebræ normal; bluish and silvery above, with metallic reflections; numerous bronze spots on sides; mouth oblique; caudal keel with accessory keels.

"This is not an abundant species, although usually met with in twos or threes during a fishing excursion of a week or more. Its flesh is excellent, and deservedly prized."

S. regalis, Bloch. (plumieri, acervum, dekayi?) Cero. [Spanish Mackerel (?). Spotted Mackerel?]

Silvery; sides with a brownish, broken, longitudinal line above and below, on which are numerous brownish spots; base of dorsal black; pectorals scaly. Dorsal rays, XVII-I, 15VIII; anal rays, II, 15-VIII. Cape Cod to Brazil; not common. May attain a weight of twenty pounds.

"Prof. Baird reports but two specimens being taken at Beesley's Point in 1854, during his stay. The writer has met with the species at Barnegat, but not abundantly." (Possibly refers to the preceding?)

SARDA, CuV.

(Pelamys, Cuv. \& Val.)

S. mediterranea, Bl. \& Schn. ( pelamys, sarda.) Bonito. Skip-jack, \&c.

Scales small, except pectoral corselet; tail strongly keeled; head large, pointed; mouth large; teeth strong and conical; first and second dorsals not far separated; followed by seven to eight finlets; first dorsal with twenty-one stout spines, posterior shortest; color steel blue, with oblique dark stripes; silvery below. Length, $2 \frac{1}{2}$ feet.

"This species is an occasional visitor in our waters. A specimen has been seen by the writer from Cape May." 


\section{ORYCNUS, Cur.}

(Thynnus.)

O. thynnus, L. (secundo-dorsaits, vulgaris, \&c.) Horse Mackerel. Tunny. Albicore.

Body robust; tail slender; an obscure corselet; pectorals do not reach beyond end of first dorsal; color dark blue above; below grayish, with silvery spots; mouth large. Dorsal rays, XIV-I, 13-IX; anal rays, I, 12-VIII. Attains a length of 10 feet or more.

"The writer has never seen a specimen of this large fish from New Jersey, but it is fair to suppose it occasionally is met with, as it is taken off Long Island frequently."-[C. C. A.]

\section{Family CARANGIDas.}

\section{Pilot-fishes.}

Body compressed, with prominent occipital keel; usually with small cycloid scales; teeth generally small ; premaxillaries protractile; spinous part of dorsal weak; anal always with two spines; airbladder often forked behind; vertebræ about twenty-five.

\section{DECAPTERUS, Bleek.}

D. punctatus, Ag: (Caranx.) Scad. Spotted Caranx. Round Robin. Cigar-fish.

Body spindle shaped; head short; mouth small, with feeble teeth; premaxillaries protractile; scales enlarged along posterior straight part of lateral line; one finlet after second dorwal and anal; bluish above; silvery below, with a dark opercular spot; pectorals short; eye small. Length, 12 inches; dorsal rays, VIII-I, 30-I ; anal rays, II-I, 24-I.

"This is a seldom-met-with species of Caranx, that is to be included in our list from a specimen taken near Cape May, and now in the museum of the Philadelphia Academy." 
D. macarellus, Cuv. \& Val. Mackerel Scad.

Silvery; leaden below; small spot on opercle; a few more rays in dorsal and anal than in above. From Cape Cod southward. Scarce.

\section{OARANX, Lac.}

(Paratractus. Trachurops. Carangus, \&c.)

O. crumenophthalmus, Bloch. Goggler. Big-eyed Sćad.

Small, scales, with larger plates on lateral line, especially on tail ; each plate armed with a spine ; preopercle serrate in young; small, uniform teeth present; body elongate, spindle shaped; bluish olive above, silvery below; opercular spot faint; head pointed; lower jaw projecting; a patch of teeth on tongue; adipose eyelid; cheeks and breast scaly; lateral line nearly straight, its plates weak and little carinated. Dorsal rays, VIII -I, 26 ; anal rays, II-I, 22 ; scutes, 35.

"The writer has never met with a species of this fish accredited to our coast, or rather the coast of the whole Atlantic."-[C. C. A.]

O. chrysus, Mitch. (hippos, pisquetus.) Hard-tail. Jural. Crevallé. Yellow Caranx.

Body ovate, nearly fusiform; greenish olive above, golden yellow below; a black blotch on opercle; teeth comparatively large, one series in lower, two in upper jaw ; top of head naked, with mucous pores; scutes developed whole length of lateral line. Dorsal rays, VIII-I, 24 ; anal rays, II-I, 19 ; scutes, 50 ; length, 12 inches.

"Paratractus hippos.

"Not uncommon during the summer along our coast."

The following remark probably refers to a variety of preceding species:

"Carangus chrysos. Yellow Caranx.

"This species is not an abundant one on our coast, although more so during some seasons than others."-[C. C. A.]

C. amblyrhynchus, Cuv. \& Val. (falcatus.)

Greenish above, with blue reflections; sides and belly golden or silvery; tail fin yellow; body ovate, deeper than preceding; mouth very small and oblique; eye large; lateral scutes strong; teeth strong, in one series; cheeks naked; lateral line strongly arched; scaly sheaths of dorsal and anal well developed; pec- 
torals falcate, reach anal. Dorsal rays, VII-I, 28; anal rays, II-I, 25 ; lateral-line scutes, 50. West Indies northward. Not common.

C. hippos, L. (defensor, caninus, carangus, chrysos, esculentus, \&c.) Horse Crevalle. Southern Caranx.

Olivaceous above; sides and below golden or silvery; a black blotch on opercle; anterior edge of dorsals black; head large and deep; back strongly arched; teeth in upper jaw in a broad band; distinct canines in lower jaw ; arched part of lateral line three-fourths that of straight part; breast naked; scales in front of ventrals only; about thirty lateral-line scutes. Dorsal rays, VIII-I, 20; anal rays, II-I, 17 . Cape Cod to West Indies. Common southward.

"This species is much more numerous during some seasons than others, but is generally to be met with in August and September in small companies."

\section{BLEPHARIS, Cuv.}

B. crinitus, Akerly (Zeus, Caranx sutor). Shoemaker.

Body rhomboid, much compressed; apparently naked, with large scales on posterior part of lateral line; bands of villiform teeth in mouth; first dorsal with rudimentary spines, disappearing with age; generic characters otherwise much as in Caranx; bluish above, golden below; blotch on opercle on dorsal and anal ; mouth oblique in young; first rays of dorsal filamentous ; soft rays of second dorsal and anal, nineteen and sixteen respectively.

"This species is very rare on our coast, single specimens being met with at long intervals."

\section{SELENE, Lac.}

(Argyriosus.)

S. vomer, L. (Zeus, capillaris, argentea, pacificus.) . Rostrated Dory. Hair-finned Silver-fish. Moonfish. Horsehead, \&c.

Body much compressed, with nearly circular profile, very steep in front; premaxillaries protractile; tongue narrow, free; teeth minute; spines filamentous in young; lateral line unarmed; bluish above, below golden silvery; soft rays, dorsal and anal, twenty-two and twenty. Different varieties or stages 
of development are referred to in the following three notes by C. C. A. :

"Argyreiosus capillaris. Hair-finned Silver-tish.

"Specimens of this fish are met with along our coast nearly every summer, but they are never abundant. They appear during August and September, and prefer the open sea.

"Argyreiosus vomer. Rostrated Dory.

"This is a very rare species in our waters. The writer has never met with a specimen except from southern waters.

"Selene argentea.

"Described by Brevoort, in Annals Lyceum Nat. Hist. N. Y., Vol. V. No specimen has been seen by the author."-[C. C. A.]

S. setipinnis, Mitch. (Vomer, browni, eurtus.) Horsefish. Blunt-nosed Shiner.

Greenish above, golden silvery below; body less rounded, more oblong, than in preceding, but profile nearly vertical, highest over eye; young with a blotch at origin of straight part of lateral line; snout somewhat protruding; mouth oblique; ventrals minute; dorsal and anal very low, no long rays in the adult; second dorsal and anal soft rays, twenty-one and seventeen.

"Specimens of this fine fish are taken every summer along our coast. It does not appear to have favorite haunts, but it is about equally distributed from Sandy Hook to Cape May."

\section{OHLOROSCOMBRUS, Grd}

(Micropteryx. Seriola.)

O. chrysurus, L. (cosmopolita, chloris, caribbæus.) Yellow-tail.

Body ovate, compressed, not elevated; belly more convex than back; tail very narrow, caudal forked; scales small, smooth; head nearly naked; mouth small, oblique; upper jaw protractile; teeth feeble; eye large ; first dorsal of eight feeble spines ; second and anal low, with twenty-six rays; strong anal spine. Common southward.

"This is not a common species in our waters." 
TRACHYNOTUS, Lac.

(Bothrolømus. Doliodon.)

T. carolinus, L. (pàmpanus.) Common Pompano. Carolina Lichia. Spiny Dory (?).

Body ovate, compressed ; abdomen not trenchant; head blunt ; snout abruptly truncate; mouth nearly horizontal; teeth villiform, deciduous; first dorsal of six spines, united in young, separate in adult, and often disappearing; three stout spines in anal; no caudal keel; preopercle armed in young with three spines; bluish above; sides silvery, becoming golden with age; body without dark bands, and no black(?) on vertical fins; fins silvery or dusky. Soft rays, dorsal, 25 ; anal, 23 ; length, 18 inches.

"This little fish is very abundant on our coast, and was met with by Prof. Baird in large numbers about Beesley's Point." A species with four vertical black bands under the dorsals, known as $T$. glaueus, Gaff-topsail Pompano, ranges scarcely as far north as New Jersey. The following is probably a stage of preceding :

"Trachynotus spinosus. Spinous Dory.

"This species was found by Prof. Baird associated with $T$. carolinus in very small numbers."

\section{NAUCRATES, Raf.}

(Nauclerus, Cuv.)

N. ductor, L. (noveboracensis.) Pilot-fish. Romero.

Differs from next only in having first dorsal of four or five low, unconnected spines (connected in young); bluish, with five to seven dark vertical bars; little compressed, but elongate; mouth small and oblique. Soft rays, dorsal, 26 ; anal, 16. More abundant southward.

"This species, although abundant elsewhere, and well known, is not often seen in our waters. A specimen from Beesley's Point is in the museum of the Philadelphia Academy."

\section{SERIOLA, Ouv.}

(Halatractus, Gill.)

\section{S. carolinensis, Holb. (zonata, stearnsii.) Amber-fish.}

Occiput and breast not trenchant; head conical ; mouth large, with broad bands of villiform teeth; lateral line nearly straight, 
forming a keel on tail ; scales on sides of head; first dorsal with seven low, connected spines; much like Naucrates; bluish above; a greenish-yellow band along side; white below; fins greenish; body spindle shaped; one median and two lateral series of teeth on tongue; head naked; cheeks with small scales; soft rays of dorsal, 36 ; of anal, 19 ; no sharp keel at occiput. Gulf of Mexico. Rare northward. The following note probably refers to aged specimens of following species, or possibly to S. fasciata :

\section{"Halatractus carolinensis.}

"Specimens of this species are occasionally met with associated with the following."

S. zonata, Mitch. (Zonichthys, carolinensis, without vertical bands, due, perhaps, to increased age.) Banded Leriole. Rudder-fish.

Differs from preceding in having six broad, black bars (darker in young than in previous cases); body deeper, with occipital keel; spinous dorsal and ventrals black. Rays, dorsal, 38; anal, 21 ; length, 30 inches.

"This species is quite abundant along our coast. Specimens have been met with by the author at each of the principal points along our coast."-[C. C. A.]

S. fasciata, Bloch. (Zonichthys.) Amber-fish.

Greenish above, with sixteen brown, narrow cross bands, arranged in pairs, and running into the dorsal and anal; head deeper than long. Dorsal rays, 30; anal rays, 20. Coast of South Carolina. Extra-limital to New Jersey.

\section{OLIGOPLITES, Gill.}

(Scombroides, Lac.)

O. saurus, Bl. \& Schn. (Scomber, occidentalis.) Leather-jacket.

Body compressed, nearly lanceolate; tail slender, not keeled; head short, acute; occipital keel sharp; mouth with sharp teeth on jaws, tongue, \&cc. ; upper jaw not protractile ; maxillary narrow, without a distinct supplementary bone; scales small and very narrow; dorsal spines $5+1$, strong; second dorsal mostly broken up into finlets; anal longer, also with finlets posteriorly; pterygoids toothless; bluish above, bright silvery below; fins yellow; caudal deeply forked; twenty soft rays in dorsal and anal. Tropics to New York. Not rare southward. 


\section{Family POMATOMIDE.}

\section{Blnefishes.}

Scales weakly ctenoid; mouth large and oblique, with premaxillaries protractile; lower jaw projects : supplementary bone to maxillary ; teeth strong, unequal, a triangular patch on the vomer ; occipital keel strong; free edge of opercle serrated; branchiostegals seven; cheeks and opercles scaled; anal and soft dorsal scaly ; first dorsal of seven low spines; ventrals thoracic; vertebræ as in Carangidoe.

\section{POMATOMUS, Lac.}

(Temnodon, Cur.)

P. saltatrix, L. (Perca, Gasterosteus.) Bluefish. Greenfish. Skip-jack. Bluish or greenish above and silvery below; a black blotch at base of pectoral ; body robust, slightly compressed; belly with blunt edge; top of head naked. Rays in dorsal and anal, 25 ; scales in lateral line, 95 ; length, 3 feet. Voracious and destructive to other fishes. Valued for fuod.

"This is a well-known and exceedingly abundant species found along our coast generally. Isolated specimens wander up the Delaware occasionally as high as Bordentown, Burlington county."

\section{Family STROMATEIDA.}

\section{Broad Shiners.}

Scales minute, cycloid; profile of body blunt in front; mouth small; no teeth on vomers or palatines; essophagus armed with horny, hooked teeth; dorsal fin single, long, spines weak; anal with three spines; usually no air-bladder.

\section{STROMATEUS, L.}

(Poronotus. Peprilus.)

S. paru, L. (Rhombus longipinnis, gardenii.) Rudder-fish. Harvest-fish.

Body ovate; tail slender; scales loosely inserted; ventrals represented by a spine; pectorals narrow, nearly half as long as 
body; first rays of dorsal and anal high; caudal forked. Dorsal rays, 45 ; anal rays, 40 ; lateral-line scales, 90 ; vertebræ, $15+15$. Commonest southward.

"This is a rare species, said to be met with occasionally in our waters."

S. triacanthus, Peck (Rhombus cryptosus). Harvest-fish. Dollar-fish. Butter-fish. La Fayette.

Dorsal and anal not very high in front, with a series of large pores along base of dorsal. Dorsal rays, III, 45 ; anal rays, III, 38 ; length, 10 inches.

"This is not a common species, and is met with almost entirely during July and August. The writer has seen single specimens from various points along the coast." - [C. C. A.]

\section{LIRUS, Lowe.}

(Palinurichtbys. Palinurus.)

L. perciformie, Mitch. (Pammelas, Leirus, Mupus, \&c.) Pilot. Rudderfish.

Body elongate-ovate and a little compressed; profile very blunt; opercular bones finely serrated; scales more fixed than in preceding; cheeks scaly; six to eight short but strong spines in dorsal; vertical fins scaly at base; ventrals $(I, 5)$ large and thoracic; dark green ; belly not silvery; eye large, with adipose eyelid; top of head naked, with mucous pores; pectorals long. Dorsal rays, 21 ; anal rays, 16 ; lateral-line scales, 75 ; length, 12 inches.

"This species is not unfrequently met with during the summer months some seasons, but as a general thing is not met with in our waters. Isolated specimens have been seen by the writer from Sandy Hook, Barnegat and Atlantic City."-[C. C. A. $]$

\section{Family CORYPHENIDE.}

\section{Dolphins.*}

Body elongate, compressed, covered with small cycloid scales; cleft of mouth wide, oblique; lower jaw projecting; teeth cardiform, some

* These fishes should not be confounded with aquatic mammals of the same name. 
on vomer, \&c.; villiform teeth on tongue; skull with a high crest; dorsal fin along entire back nearly; no distinct spines; pectorals short; caudals widely forked; no air-bladder nor pseudobranchs.

\section{CORYPH丑NA, L.}

(Lampugus.)

C. equisetis, L. (immaculata punctulatus.) Spotted Dolphin, or Lampugus. Small Dolphin.

Bluish above, paler below, and yellowish; sides sometimes sprinkled with small blue spots, larger at base of dorsal ; dorsal blue, wavy, with rows of spots; none on anal; profile of snout does not become vertical with age. Dorsal rays, 51 to 56 ; anal rays, 24 to 26 ; length, $2 \frac{1}{2}$ feet.

"The writer has not met with this species. Said to have been caught at the mouth of the Hudson River."-[C. C. A.]

\section{C. hippurus, L. (guttata, sueuri) Great Dolphin.}

Colors brilliant when captured, changing suddenly at death; brownish olive above, golden below, with bright blue spots; dorsal purplish, with lines; other fins tinged blue; caudal yellow, pale, with blackish spots in preserved specimens; profile becomes vertical with age; male with a crest, female with blue spots on each side of tail.-Poey. Dorsal rays, 58 to 64 ; anal rays, 26 to 30 ; length, 6 feet. Common in warmer seas.

"This handsome and interesting species is not abundant along our coast, although specimens are met with every summer at the various coast villages, as Long Branch, Tuckerton, Toms River, \&c."-[C. C. A.]

\section{Family APHREDODERIDaz.}

\section{Pirate Perches.}

Body oblong, elevated at base of dorsal, compressed behind, with head thick and depressed; lower jaw projecting; teeth in villiform bands; opercle with a spine, some of bones serrated; bones of skull ravernous; branchiostegals six; scales ctenoid, adherent; lateral line 
imperfect; vent moves forward towards opercalar region with age; ventrals thoracic ; anal small ; air-bladder adherent to walls of abdomen.

\section{APEREDODERUS, Le S.}

(Scolopsis, Gilliams.)

A. sayanus (gibbosus, cookianus, mesotrema, isolepis, \&c.) Pirate Perch. Mud Perch.

Dark olive, much speckled with dark points; two blackish bars at base of caudal, between which is a light bar. Dorsal rays, III, 11 ; anal rays, II, 6 ; lateral-line scales, 47 to 58 ; length, 5 inches.

"Met with in Mercer, Burlington, Camden and Atlantic counties. No species is perhaps less known, of all our freshwater fishes, than the above. Being strictly nocturnal in its habits, will account in a measure for this, but its numbers are great in those streams where it is found at all, and only its peculiar habit of lying semi-dormant during the day, will account for the fact of its being a 'rara pisces' to the community generally. Small streams with dense vegetation upon the bottom, and with overhanging banks, are its favorite, if not exclusive haunts. Among the roots of some neighboring tree, whose tangled rootlets extend out into the stream, the 'pirate' is sure to be found in streams containing them, but it requires skill and patience to secure them, when thus protected. No species in the State's fauna is perhaps as voracious as this under consideration. Even its own young are not exempt from attack, and indeed they seem to be somewhat of a favorite article of food. So greedy are they at times, that not unfrequently the tail of the captured fish may be seen protruding from the mouth of its captor, who seeks his favorite haunt after seizing his prey, and there, lazily flapping his pectoral fins to and fro to give his body a gently swaying motion, devours the swallowed victim at his leisure.

"The 'pirate' makes a nest after the manner of the sunfish, and with the female, guards it and afterward the young, till they reach a size of one-third of an inch, when they are left by their parents, and become exposed to the attacks of the larger carnivorous fish, including their own species.

"The largest specimens met with have measured about five inches in length. De Kay's figure is a correct representation." 


\section{Family Centrarchide.}

\section{Sunfighes.}

Compressed; body deep, not very long; mouth well toothed with villiform teeth in bands; premaxillaries protractile; opercle ends in .two flat points or a black flap; branchiostegals six (or seven); body fully scaled (ctenoid, rarely cycloid); usually ten spines in dorsal; intestine short; vertebræ about thirty, number changes with age; pseudobranchs rudimentary; sexes alike; voracious. Valued for food according to size.

POMOXYS, Raf.

(Labrus. Centrarchus.)

P. sparoides, Lac. (hexacanthus, nigromaculatus.) Grass Bass. Barfish: Calico Bass. Strawberry Bass.

Snout projecting; mouth large, oblique; few teeth on tongue; scales large; anal fin larger than dorsal ; opercle with two points; dorsal spines seven or eight, not six; scales on cheeks in six rows; fins very high; color silvery olive, mottled with olive green in small bunches over whole body; anal marked with reticulations and spots liké dorsal. Dorsal rays, 15 (soft); anal rays, 17 ; lateral-line seales, 41 ; length, 12 inches. Chiefly in lowland streams and lakes.

\section{AMBLOPLITES, Gill.}

(Lepomis. Bodianus.)

A. rupestris, Raf. (æneus, cavifrons?) Common Rock Bass. Red-eye. Goggle-eye. Mud Sunfish.

Mouth large; lower jaw projecting; lingual teeth in one patch; opercle with two points; scales large; dorsal larger than anal, with ten to eleven low spines; six spines in anal; scales on cheek in six to eight series; color olive green, brassy, with dark mottlings; the young irregularly barred and blotched black; adult has a dark spot on each scale; black opercular spot. Soft rays, dorsal, 10 ; anal, 10 ; length, 12 inches.

"The writer captured a specimen of this northern species in October of 1867 , in Mercer county. It is the only one met with."-[C. C. A.] 


\section{ACANTHAROHUS, Gill.}

(Centrarchus.)

A. pomotis, Bd. (Ambloplites-Abbott's Catalogue.) Mud Sunfish.

Body oblong, not much compressed nor elevated ; mouth wide, with short gape; lower jaw projecting; pharyngeal teeth sharp; scales large, cycloid; dorsal spines low, eleven; anal five; caudal fin rounded; cheeks with five rows of scales; color dark green, with five indistinct longitudinal bands on sides; also bands on cheeks ; an opercular spot; fins plain. Soft dorsal and anal rays, 10 ; length, 4 inches.

"This is a less abundant species than the one following, but in its habits is somewhat similar. Specimens kept by the writer in an aquarium, devoured many small cyprinoids and wounded the other large fish so that many of them died." - [C. C. A.]

ENNẸACANTHUS, Gill.

(Hemioplites. Copelandia.)

F. obesus, Bd. (Pomotis, -Bryttus, fasciatus, guttatus.) Spotted-finned Sunfish.

Body short, deep, compressed; mouth small, with welldeveloped supplementary bone; no teeth on tongue; opercle with two points; anal large, but smaller than dorsal; scales large; opercular spot more than half as large as eye; cheeks with four rows of scales; color olivaceous, with five to eight dark cross bars and purplish-golden spots on body and fins; lines and spots on cheeks; bar below eye. Dorsal rays, IX, 10 ; anal rays, III, 10 ; scales, $32 \times 10$; length, 3 inches.

"This species is very abundant in many tributaries of the Delaware, in Mercer and Camden counties. It is likewise a lover of sluggish water, and is found usually in the midst of a mass of weeds, from which it must be dragged with a net, as it does not ever, or very seldom, bite at a hook."

E. simulans, Cope (margaratis, guttatus, piniger-last; southern variety, larger and brighter).

Body comparatively elongate; mouth very oblique; soft rays of dorsal elevated in male, lower in female; color dark olive, with traces of vertical bars,in young; ear flap small, with blue 
border and a pearly spot in front; a dark bar below eye; males much spotted with blue, fainter in females. Dorsal rays, IX, 10 ; anal rays, III, 9 (varies). Abundant near the coast.

\section{MESOGONISTIUS, Gill,}

M. chætodon, Bd. (Pomotis.) Black-banded Sunfish.

Differs from preceding genus in having ten dorsal spines; small supplemental bone; anal much smaller than dorsal; dorsal with anterior spines longest; body suborbicular; mouth very small; lateral line continuous; cheeks three to four rows of scales; dirty straw color, clouded with olive; six to eight vertical bars on sides. Lateral-line scales, 28 ; length, 3 inches.

"This interesting species is a lover of weedy, sluggish streams and ponds, and is never met with in tide water. The writer has seen it from Mercer and Burlington counties, but could not find it in Warren, Sussex or Morris counties. It was first met with in Atlantic county by Prof. Baird."-[C. C. A.]

\section{LEPOMIS, Raf.}

(Ichthelis. Eupomotis. Apomotis, \&c.)

L. phenax, Cope \& Jord. (Apomotis, Bryttus, \&c.) Sunfish.

Body ovate; supplementary bone strong; teeth on vomer and palatines; dorsal with ten short and strong spines; opercular spot larger than eye; seven rows of scales on cheek; no black spot on dorsal or anal; color olive green, dark in adults; more silvery in young. Dorsal rays, 10 ; anal rays, 9 ; scales, $43 \times$ 14 ; length, 6 inches. Beesley's Point.

L. auritus, L. (Labrus, Bryttus unicolor, Pomotis rubicauda, appendix.) Long-eared Sunfish. Black-eared Sunfish.

Gill rakers short and thick; ear flaps long and narrow; body elongate; seven rows of small scales in cheek; scales of breast very small; palatine teeth few and large; dorsal spines low; color olive, belly orange red; scales on sides with red spots on a blue ground; vertical fins yellowish; head with bluish stripes. Dorsal rays, 11 ; anal rays, 9 ; lateral-line scales, 47 ; length, 8 inches.

The two following notes by C. C. A. refer doubtless to varieties of the above species: 
"Ichthelis rubicauda. River Sunfish.

"This beautiful fish is distinguishable by its ruddy tail and lower fins. It attains a greater size than the others, and is met with most usually in the rivers. In the Delaware they are abundant, and reach a length of several inches very frequently.

"Pomotis appendix. Black-eared Sunfish.

"This species is larger bodied and much less brilliantly colored, but in its habits is in all respects similar to the next. It is less abundant than the next, and like it, prefers quiet ponds and slowly-moving streams to the river or tide water. The black appendix easily distinguishes it from the following. As articles of food the two species are of very little value."

L. gibbosus, L. (Perca, Sparus, Pomotis, vulgaris.) Common Sunfish. Pumpkin Seed. Bream.

Body short and deep; profile steep; head and mouth small; dorsal spines high, soft rays higher; scales large, four rows on cheek; greenish olive; sides spotted with orange; belly yellowish; blue, wavy streaks on cheeks; lower part of opercular flap bright scarlet in adult. Dorsal rays, $\mathrm{X}, 11$; anal rays, III, 10 ; lateral-line scales, 47 ; length, 8 inches.

"This is probably the best-known species of all our inland fishes. It appears to be uniformly abundant in every section of the State. Its colors are brightest in the spring, when they may be seen in shallow water, making nests and guarding them from every intruder."

\section{MICROPTERUS, Lac.}

(Huro. Grystes. Lepomis, \&c.)

M. salmoides, Lac. (Labrus, pallida, Oichla floridana, nigricans, \&c.) Large-mouthed Black Bass. Oswego Bass. Green Bass. Bayou Bass [erroneously Trout (South).]

Body oblong, compressed; head long; mouth large and oblique ; supplementary bone well developed ; lower jaw prominent; opercle with two flat points ; scales weakly ctenoid ; dorsal divided by deep notch; spines low, not strong, same number as in sunfish; ten rows of scales on cheek; young dark green above, silvery below; a dark stripe on side and three on cheek; caudal blackish in middle; lateral stripe indistinct and general tone darker in adult. Dorsal rays, 13; anal rays, 11 (soft); scales, $68 \times 16$; length, 1 to 2 feet. Fresh water. Introduced 
by New Jersey authorities into Greenwood Lake, 1871. This and the following have lost in size, from lack of fresh stock for interbreeding, according to the belief of the fishermen.

M. dolomiei, Lac. (Bodianus achigan, Grystes salmoides, fasciatus, punctulatus, obscurus, \&c.) Small-mouthed Black Bass.

Head large, but mouth not as large as in preceding; scales on cheek small, seventeen rows; young golden green, with bronze luster; spots or vertical bars on sides, but no longitudinal stripe ; three bands on cheeks; adults dead green; scales, $74 \times 17$. Cool, clear and rapid streams. Introduced by authority of State of New York into Greenwood Lake, 1866.

\section{Family PERCID Es.}

(Ftheostomatidø.)

\section{Perches.}

Body elongate, terete or compressed, covered with small, adherent ctenoid scales; two dorsals, the first sping; many characters in common with the foregoing family, but body more slender; anal spines one or two ; pseudobranchiæ small or none; skull bones not cavernous.

\section{BOLFOSOMA, De K.}

(Etheostoma. Frstrella, \&c.)

B. olmstedi, Stor. (tessellatum, maculaticeps, \&c.) Tessellated Darter.

Body slender, little compressed, not translucent; head small, pointed ; cheeks and opercles scaly; scales large; breast naked; fins high ; color olivaceous, tessellated above, sides with blotches and zigzag markings; fins speckled or barred; head not speckled, dusky in males. Dorsal spines, 9; soft rays, 14; anal, 9; lateral-line scales, 50 ; length, $3 \frac{1}{2}$ inches. Breast closely scaled in var. atromaculatum.

"This is the most numerous of the described species of 'darters.' No stream appears to be too small for them, and many specimens have been found by the writer in the 'belly' of shad-nets, tangled in the vegetation and trash drawn from the bottoms of our rivers." 


\section{PERCINA, Hald.}

(Perca. Sciøna, \&c.)

P. caprodes, Raf. (Etheostoma, Pileoma semifasciatum, carbonaria, \&c.) Banded Darter. Log Perch. Rockfish. Hogfish.

Body compressed, with long, pointed head, depressed above; cheeks, opercles and neck scaly; chest naked; fins low; color yellowish green, with about fifteen long cross bands on sides, alternating with short ones; fins barred. Dorsal rays, XV15 ; anal rays, II-9; lateral-line scales, 92 ; length, 6 to 8 inches. Mouth overlapped by a pig-like snout.

"This species I have only met with in the Delaware, and there it is a by-no-means-abundant species. It appears to move about more than the other species, sustaining itself for a greater length of time in the water."

\section{ETHEOSTOMA, Raf.}

(Catonotus, Ag.)

F. flabellare, Raf. (humeralis, fasciatus.) Fan-tailed Darter.

Head naked; lateral line short and nearly straight; spinous dorsal low, ending in fleshy knobs in males; color olivaceous, dusky above, with obscure bars; scales with brown spot forming obscure lines; head narrow ; mouth oblique; fins barred. Dorsal rays, VIII-12; length, $2 \frac{1}{2}$ inches. Western New York and southward. Possibly extra-limital to New Jersey.

\section{PECILIOHTHYS, Ag.}

(Oligocephalus. Boleichthys. Aplesion. Alvarius. Astatichthys. Hololepis, \&c.)

P. coeruleus, Stor. (variatus, Jord.) Blue Darter. Rainbow Darter. Soldier-fish.

Body robust; back elevated; head large, compressed; neck, cheeks and breast usually naked; opercles scaly ; fins large, dorsals close together; males olivaceous, tessellated and blotched; sides with twelve indigo-blue bars, separated by orange spaces; caudal and anal deep orange, edged with blue; soft dorsal blue at base; spinous crimson; ventrals and cheeks blue; throat, \&c., orange; females with little blue or red; vertical fins barred, \&c. Dorsal rays, $\mathrm{X}-12$; anal rays, $\mathrm{II}-7$; scales, $45 \times 8$; 
length, $2 \frac{1}{2}$ inches; lateral lines, developed for 35 scales, nearly straight.

"With perhaps one exception, this is the most abundant of the species of this family found in the State. Flat rocks in shallow water, or sandy flats among rougher bottoms, are the favorite haunts of this restless species."

P. fusiformis, Grd. (Hololepis, Boleosoma.) Fusiform Darter.

Strongly compressed; head long and narrow, with short, decurved muzzle; eye large; strong opercular spine; lateral line from twelve to fifteen scales; cheeks, neck, belly and throat scaly; olivaceous, dotted with dusky points; soft vertical fins, speckled. Dorsal rays, $\mathrm{X}-9$; anal rays, II-7; lateralline scales, slightly curved, 55 ; length, 2 inches.

"In Cape May county, and at Bound Brook, Somerset county, this species is more or less abundant.

"The want of a good monograph of this family has prevented the writer from giving a complete list of the family. Occasional specimens have been frequently met with, not referable in all respects to the published descriptions, and are probably as yet undescribed species, but as this is to a certain extent doubtful, the writer did not feel justified in giving names to what might be only varieties."-[C. C. A.]

\section{P. erochrous, Cope. Red-sided Darter.}

Dorsal outline of body curved, ventral straight; head long, decurved and narrow in front; lateral line on sixteen scales; blackish above, with notched, dark band on sides; no red dots. Dorsal rays, IX-10; anal rays, II -7 ; lateral-line scales, 43 ; length, 2 inches. Streams tributary to Chesapeake and Delaware Bays.-J. \& G.

\section{MICROPERCA, Putn.}

\section{M. punctulata, Putn. Least Darter.}

Body short and deep; cheeks naked; opercles somewhat scaly; opercular spine very small; neck and chest naked; no trace of lateral line; scales ctenoid, large; anal spines strong; color olivaceous; sides speckled and with vague bars and markings; some of fins barred. Dorsal rays, VI-VII, 10; anal rays, II, 6 ; lateral-line scales, 34 ; length, $1 \frac{1}{2}$ inches. 
"Generally found in protected corners of rapid streams, resting on a flat stone or the level sand. In its movements it is very similar to $P$. coeruleus. Concerning its breeding habits the writer has gathered no particulars." - [C. C. A.]

\section{PEROA, L.}

P. americana, Schranck (Bodianus flavescens, acuta, gracilis, fluviatilis).

Yellow Perch. American Perch. Ringed Perch.

Back dark olive; sides yellow, with six to eight bars; belly pale; lower fins red or orange; cheeks closely scaled, scales imbricated; opercles naked, armed with one spine, preopercle serrated. Dorsal rays, XIII-1, 14; lateral line complete.

"This well-known species is found more or less abundantly throughout the State. In the Delaware River, specimens of unusual size have been taken, weighing over four pounds."

\section{STIZOSTEDIUM, Raf.}

(Lucioperca.)

S. vitreum, Mitch. (americana, salmonea.) Wall-eyed 'Pike. Dory. Glass-eye. Yellow Pike. Blue Pike (Var.) Jack Salmon. Susquehanna Salmon.

Pseudobranchs developed; branchiostegals seven; preopercle serrate; canine teeth in jaws and on palatines; body slender, fusiform; dark olive, finely mottled with brassy; lower jaw flesh color; belly and lower fins pinkish; black blotch on spinous dorsal. Dorsal rays, XIII-I, 21 ; anal rays, II, 12 ; lateral-line scales, 90 ; reaches a length of nearly three feet and a weight of ten to twenty pounds. Some have been put into the Delaware by Pennsylvania authorities.

\section{Family SERRANID}

(Percidæ.)

\section{Sea Bass.}

Body oblong, compressed; with usually ctenoid scales; mouth horizontal, posterior part of maxillary not slipping under edge of 
preorbital; no incisors nor molars, but often canines; pseudobranchs large; opercle with one or two points; anal short, with three spines; vertebræ twenty-five; air-bladder. adherent to abdominal walls.

\section{ROCOUS, Mitch.}

(Labrax, Cur.)

R. lineatus, Bloch. Striped Bass. Rockfish.

Anal spines strong; branchiostegals seven; teeth villiform, some on base of tongue in two patches; caudal forked; dorsal divided; no supplemental maxillary; first dorsal with nine spines; lower jaw projecting; olivaceous silvery, white or brassy below ; sides with seven or eight dark bands, one on lateral line; young slender; mouth large and oblique; twelve soft rays in dorsal and anal. Lateral-line scales, 65 ; length, 3 to 4 feet.

"Numerous in the various rivers of our State, and probably most so in the Delaware. Although met with during the greater part of the year in the rivers, it nevertheless appears to be a marine species that ascends in the spring for breeding purposes, and in the fall is again met with seeking the head-waters, this time to meet the outgoing shad, that are now making their way to the ocean to pass the winter. Many ' rockfish' winter in the salt creeks, but the majority seek the deep sea-water."

R. americanus, Gmel. (Morone, mucronata, rufus.) White Perch.

Sides not striped with black; olivaceous, with silvery sides and faint lighter streaks; back arched; head depressed and pointed; mouth small, oblique; dorsal fins united. Lateralline scales, 50 ; length, 12 inches (maximum).

"This well-known fish is abundant in the rivers of the State, and wandering from the rivers, enters the various creeks, and is to be met with in great abundance in tide-water streams in the neighborhood of flood-gates, where they congregate to catch the thousands of minnows that are swept through the gates at the 'turn of the tide.' No finer sport is to be had than fishing for 'white perch' at this time.

"This fish is abundant on the coast during the late autumn and winter, and from the brackish streams and various fishinggrounds it is brought at this time of year to the markets. They rarely reach over a foot in length, if ever. The largest specimen preserved at Philadelphia measures one foot." 


\section{SERRANUS, OUV.}

(Centropristis. Perca.)

S. nigrescens, Bl. \& Schn. (atrarius.) Northern Black Sea Bass. Blackfish.

Canine teeth of outer row small; caudal fin trilobed; color dusky, more or less mottled, with traces of pale longitudinal streaks along the rows of scales; young greenish, often with dark lateral band, sometimes cross bars; dorsal with whitish spots; body robust; head large, little compressed; top of head naked; about eleven rows of scales on cheeks; mouth oblique, low; dorsal spines strong; pectorals as long as ventrals (longer in southern variety, atrarius). Dorsal rays, $\mathrm{X}, 10$; anal rays, III, 7 ; lateral-line scales, 50 ; length, 12 inches.

"This species is the best known of our coast fish to the marketpeople. During the spring and summer it is brought in great numbers from our coast generally. The species never reaches a very great size, the largest specimens met with by the author measuring fifteen inches."

\section{CREOLUS, J. \& G. \\ (Paranthias. Brachyrhinus, \&c.)}

O. furcifer, Cuv. \& Val. (Serranus.)

Is a revision of the following:

"Epinephelus oxypteras. Sharp-finned Corvina.

"A specimen of this fish is described in De Kay's Report, as having been met with in New York. The writer has not seen a living specimen."-[C. C. A.] Its occurrence on our coast is still doubtful.

\section{TRISOTROPIS, Gill.}

T. stomias, G. \& B. Black Grouper.

Dark gray, freckled with paler, but no distinct spots ; fins tipped with black; mouth large; body slender; scales smooth, with many accessory scales. Lateral-line scales, 140. Rare north of Virginia. The following note seems to refer to a variety of the next species:

"Epinephelus moris. Groper.

"There is but one specimen preserved from the coast of New Jersey known to the writer. A southern species." 


\section{EPINEPHELIS, Bloch.}

E. morio, Cuv. (erythrogaster.) Red Grouper.

Brownish, marked with ash; salmon below; fins margined with blue; scales of lateral line triangular, cycloid; elsewhere small and ctenoid; medium crest of cranium developed; opercle with two spines. Dorsal rays, XI, 17; anal rays, III, 9 ; lateral-line scales, 106. Southern.

"Occasionally met with along the coast. The writer has seen a specimen taken at Beesley's Point."-[C. C. A.]

\section{DULES, Cuv.}

D. auriga, Cuv. \& Val. Coachman. Charioteer.

This genus is distinguished by having third dorsal spine filamentous. Doubtful if ever taken on our coast.-J. \& G.

"A specimen of this fish is preserved in the museum of the Academy of Natural Sciences of Philadelphia,'labeled 'Cape May, N. J.' The writer has seen no other specimen from State limits."-[C. C. A.]

\section{Family SPARID ż.}

Scales ctenoid, sometimes nearly cycloid ("sparoid"); head large ; premaxillaries protractile; maxillary without supplemental bone, and slipping under preorbital for its whole length; pseudobranchs well developed.

\section{LUTJANUS, Bl. \& Schn.}

(Mesoprion. Diacope, \&c.)

L. caxis, Bl. \& Schn. (griscus, Neomænis emarginatus.) Yelting. Gray Snapper.

Head long; mouth large; jaws with bands of villiform teeth, with well-developed canines in upper jaw, an anchor-shaped patch of teeth on vomer and one patch on tongue; caudal fin lunate; color greenish olive, each scale with a brown spot; cheeks with six rows of scales. Dorsal rays, $\mathrm{X}, 14$; anal rays, III, 8 ; lateral-line scales, 48. 
"This small species was first described by Prof. Baird in 1854, he having procured specimens at Beesley's Point. It is an abundant species in the salt rivers on the southern portion of our coast, frequenting the grassy-grown coves, and seldom seen where the water is free of vegetation."

POMADYS, Lac.

(Pristipoma, Cur.)

P. fulvomaculatus, Mitch. (Orthopristis, Labrus, Hæmulon.) Speckled Red-mouth. Hogfish. Sailor's Choice.

Vomer, palatines and tongue toothless; dorsal fin continuous; body not much elevated; head long, with conical snout; mouth low and small, outer teeth slender and short; dorsal and anal naked to base, where is a sheath of scales; posterior spines lower than soft rays and anterior spines; caudal forked; color light brown, silvery below, orange-yellow spots on sides, in rows, oblique above lateral line, horizontal below; head blue and spotted. Dorsal rays, XII, 16 ; anal rays, III, 12 ; lateralline scales, 57 ; length, 12 inches.

"During the summer of 1865, numbers of this fish were taken off Sandy Hook, and the writer has seen specimens since, caught near the mouth of the Delaware River. It is a visitor to our coast, however."-[C. C. A.]

P. virginicus, L. (Anisotremus, tæniatus, Sparus.)

Golden olive above; a dusky bar from nape through eye, and from dorsal downward, behind which are several light-blue, narrow stripes; body ovoid, compressed and elevated; outer teeth strong; eye large; second anal spine longer than third. Dorsal rays, XII, 17 ; anal rays, III, 9.

"An occasional specimen of this fish has been taken on our coast, and the writer met with a specimen in the fish-market at Trenton, said to have been received from Barnegat." - [C. C.. A.]

\section{DIABASIS, Degm.}

(Hømulon, Cuv.)

D. plumieri, Lac. (Perca formosa, H. arcuatum.) Black Grunt. Squirrel-fish.

Brownish above, lighter below; head with twelve or more wavy lines of blue; fins dusky blue; body highest at dorsal; 
profile very convex to base of snout; second anal spine much enlarged; inside of mouth red; soft part of fins scaled; caudal forked. Dorsal rays, XII, 17 ; anal rays, III, 9; lateralline scales, 55 .

"A single specimen of this fish was taken in Delaware Bay, in July, 1867, and is now in the possession of the writer. It is a rare visitor to our waters."

D. aurolineatus, Cuv. \& Val. (chrysopterus, quadrilineatum.) Yellowfinned Red-mouth.

Olive brown above; sides silvery; mouth large, red; back less elevated than in preceding; profile nearly straight; a narrow bronze band from snout through eye to caudal, and three or four stripes on head and anterior part of body; vomer, \&c., toothless; soft part of fins scaled; dorsal continuous. Dorsal rays, XIII, 15 ; anal rays, III, 8 ; lateral-line scales, 55.

"This species is more frequently met with than the preceding, but is only a visitor to our waters. The writer has seen them exposed for sale in the Trenton fish-market." - [C. C. A.]

\section{LOBOTES, Cuv.}

(Holocentrus, Bloch.)

L. surinamensis, Bloch. (auctorum, erate.) Flasher. Black Triple-tail.

Blackish above, becoming silvery gray on sides, often blotched and tinged with yellow; fins dusky; head small, profile concave in front, convex from occiput to dorsal; scales on opercle large, small around eye; pectorals shorter than ventrals, spines lower than soft dorsal; caudal fin convex; jaws with bands of villiform teeth, in front of which are a series of larger ones; none on vomer. Dorsal rays, XII, 16; anal rays, III, 11; lateralline scales, 47 ; length, 2 to 3 feet.

"This is not a common species in our waters. The museum of the Philadelphia Academy contains specimens from Beesley's Point, and from.Cape May."

\section{STENOTOMUS, Gill.}

(Sparus, Pagrus.)

S. chrysops, L. (aculeatus, argyrops.) Southern Porgee. Gilt-head.

Differs from following in having body larger, less elevated, more elongated, with coarser molar teeth; color silvery, with 
reddish tinge and golden streaks; head large; two rows of molars, the inner series the larger; six strong, canine-like teeth in front of upper jaw ; five rows of scales on cheek and four on opercle; fins reddish. Dorsal rays, XII, 12; anal rays, III, 11 ; scales $7-48-14$; length, 18 inches.

"This species is included in our list, from the fact of various authorities making mention of it, but the author has not met with it."-[C. C. A.]

S. versicolor, Mitch. (argyrops, Sargus ambassis.) Scuppaug. Porgee. Sand Porgee (?). Northern Scup.

Brownish, silvery below; everywhere with blue reflections; vertical fins mottled; young faintly barred; body compressed; back elevated; head deep; mouth small ; incisors very narrow; molars in two rows above; cheeks with four rows of scales. Dorsal rays, XII, 12 ; anal rays, III, 11 ; scales $8-49-16$; length, 12 inches.

"Found generally along the coast, more abundantly after July. They enter the bays in large numbers, and are also caught at sea in very deep water. They are prized as a market fish, and are largely sold throughout the country and in towns not too remote to render transportation impracticable."

The following note probably refers to a variety of $S$. versicolor, or possibly of $S$. chrysops.

"Stenotomus arenosus. Sand Porgee.

"This is not an abundant species on the coast. They are generally met with in August and September. Author has caught them near Tuckerton and Atlantic City."-[C. C. A.]

\section{LAGODON, Holbr.}

L. rhomboides, L. (Sparus, Sargus.) Pinfish. Bream. Rhomboidal Porgee.

Brownish, white below; sides with horizontal light-blue and golden stripes, and half a dozen faint, dark, vertical bands; disappearing with age; vertical fins yellowish, with bluish stripes; body elliptical; head sharp; mouth small and upper jaw protractile; incisors broad and notched; cheeks with five to six rows of scales; a procumbent spine before dorsal, latter in spiny part high. Dorsal rays, XII, 11 ; anal rays, III, 11 ; scales, 8-66 -18 ; length, 12 inches, 
"This species the author has seen a specimen of, in a small collection made at Beesley's Point, and now in the museum of the Philadelphia Academy."-[C. C. A.]

\section{DIPLODUS, Raf.}

(Archosargus, Gill.)

D. probatocephalus, Walb. (ovicephalus, Gill., Sparus, Sargus ovis.) Sheepshead.

Grayish, with eight vertical black bands; fins dark; body robust, very deep in old examples; back compressed and elevated; profile very steep; mouth low, horizontal; incisors broad, serrated in young; cheeks with six rows of scales; scales on breast small and crowded ; dorsal spines high ; soft dorsal lów ; second anal spine strong. Dorsal spines, XII, 12 ; anal spines, III, 10 ; scales, $7-45-16$; length, 30 inches.

"This fine fish is quite abundant and most eagerly sought after. They are found on the coast from June or July, according to the season, until October. Opposite the village of Barnegat this species is met with quite abundantly, and many are taken by the professional fishermen during the summer months."

\section{OYPHOSUS, LAC.}

(Pimelepterus, Lac.)

C. bosqui, Lac. (flavolineatus, Perca sectatrix.)

Dusky, with about twenty-five light stripes following the rows of scales; scales of back and belly smaller than on sides; soft dorsal and anal very low, the latter short; caudal with lower lobe longer ; top and sides of head and fins finely scaled; incisors lanceolate, with backward projecting processes. Dorsal rays, XII, 12 ; anal rays, III, 11; scales, $10-66-20$; vertebræ, $9+16$. Massachusetts to Panama. Common southward.

\section{Family SCI AENIDEe.}

\section{Croakers.}

Skull cavernous; head scaly; no teeth on vomers, \&c.; lateral line extends on to the caudal fin; scales thin and ctenoid; mucous 
pores much developed; ear bones large; dorsal fin not continuous; air-bladder large, perhaps used in producing peculiar grunting sounds, by squeezing air into lateral horns.

POGONIAS, Lac.

(Labrus.)

P. chromis, L. (fasciatus, Holb.) Big Drum. Banded Drum.

Grayish silvery, with four to five broad, dark, vertical bars that disappear with age (once considered as two species as to whether " banded" or not; the young are banded, large examples not); body compressed, oblong, with steep profile; scales large (except on breast); pectoral fins large; head scaly on top; outline of belly not much curved; upper jaw longest ; teeth small ; lower pharyngeals united, armed with paved teeth; lower jaw with short barbels; second anal spine very large. Dorsal rays, $X$, I, 20 ; anal rays, II, 6 ; lateral-line scales, 50 . Abundant southward. Occasionally schools of them raid the planted beds of the oystermen and make sad havoc.

"Pogonias chromis. Big Drum.

"This is by no means as common as the succeeding species, but is nevertheless not a rare species. They are met with from Sandy Hook to Cape May, during the summer and early autumn.

"Pogonias fasciatus. Banded Drum (young of preceding).

"This well-known species is abundant in the bays along the coast, and is frequently found on the beach after a storm, killed by the violence of the waves."

\section{SOT开NA, L.}

S. chrysura, Lac. (punctata, argyroleucus, Homoprion xanthurus, Bodianus, Perca, Corvina, Bairdiella.) Silver Perch. Yellow-tail, \&c.

Greenish above, silvery below, each scale with a group of dark points in center; fins plain, caudal yellow; body robust; head conical; preopercle serrated at its angle; jaws with stout teeth ; region between eyes narrow and normal; anal fin small and far back; pectorals short, pharyngeals separate, with sharp teeth; chin with pores, no barbels; teeth in jaws in one main series, bands narrow. Dorsal rays, XI, I, 22; anal rays, II, 9; lateral-line scales, 50 . 
"This species is not very abundant, although specimens are not difficult to procure, if search is made for them where fishing is actively carried on."

S. ocellata, L. (Perca, Corvina, Sciænops.) Redfish. Red Bass. Channel Bass. Red Horse.

- Grayish silvery, iridescent; scales with dark spots; at least one spot on caudal; pectorals short; teeth in both jaws in broad bands; preopercle serrate; outer teeth in upper jaw considerably enlarged. Dorsal rays, $\mathrm{X}-\mathrm{I}, 25$; anal rays, II, 8 ; lateralline scales, 50 ; attains 20 to 50 pounds.

"An occasional visitor to our waters, and seldom met with but as a straggler with other scieænoids."

\section{LIOSTOMUS, Lac.}

L. zanthurus, Lac. (Sciæna, Mugil, obliquus.) Spot. La Fayette. Oldwife. Goody.

Bluish above, silvery gray below, with fifteen dark, oblique bands; fins plain, caudal not yellow; profile steep, snout blunt; anal spines small; teeth feeble, permanent in upper jaw only. Dorsal rays, X, I, 32 ; anal rays, II, 12 ; lateral-line scales, 60 ; length, 12 inches.

"This is a well-known species, visiting the coast in summer, and in great numbers. It is known at Cape May as the 'Cape May Goody.'"

The variety obliquus has bars and spots, and is probably old adults; the var. xanthurus is plain, hence following note:

"Liostomus obliquus.

"This is not as common a species as the preceding, but is occasionally met with in large numbers. During the summer of 1865 many were taken near Barnegat, and the writer saw them exposed for sale in the Trenton fish-market." - [C. C. A.]

\section{MICROPOGON, Ouv, \& Val.}

M. undulatus, L. (Perca, lineatus.) Croaker.

Bright grayish silvery; sides and back with narrow undulating lines of dots, three lines of dots along base of dorsal; head long; preopercle serrate or spiny ; second anal spine weak; lower jaw toothless; teeth weak in upper jaw. Dorsal rays, $\mathrm{X}$, 
I, 32 ; anal rays, II, 12; lateral-line scales, 60 ; length, 12 inches. Cape Cod to Florida. Valued for food.

"This is a very rare species on our coast, and can scarcely be considered as a member of the fauna."

\section{MENTICIRRHUS, Gill.}

M. nebulosus, Mitch. (Umbrina.) Kingfish. Whiting. Barb.

Irregular dark bars, those in front run backward and downward, those further back the reverse; fins all dusky; body terete, elongate; snout very blunt; eyes small; lower jaw with one thick barbel; no air-bladder; only one anal spine; teeth in both jaws; dorsal spines high ; soft dorsal low and long. Dorsal rays, X-I, 26 ; anal rays, I, 8 ; lateral-line scales, 68.

"This fine fish is abundant on our coast, but is not frequently met with in the markets, or the wagons of traveling fishmongers. As an article of food it has no rival."

\section{CYNOSCION, Gill.}

(Cestreus, Gronow.)

O. regale, Bl. \& Schn. (Johnius, Otolithus.) Weakfish. Gray Trout. Squeteague.

Silvery, darker above, blotched, and with oblique undulating lines; second dorsal and caudal dusky and scaly; lower fins yellow or speckled; teeth sharp, in narrow bands; pectorals short; one or two canines in upper jaw only ; lower jaw projecting; vertebræ, $14+10$; body elongate, little compressed ; mouth large; anal spines feeble, one or two; caudal not forked. Of high rank as food-fishes.

"This is a very abundant species, well known along our coast. It affords excellent sport from the manner of seizing the hook, but is of little value as an article of food."

O. maculatum, Mitch. (Labrus squeteague, var. maculatum, Otolithus caralinensis, drummondii.) Spotted Sea Trout.

Bright silvery, darker above; back with numerous black spots, also on dorsal and caudal fins; pectorals short. Dorsal rays, $\mathrm{X}-\mathrm{I}, 25$; anal rays, I, 10 ; lateral-line scales, 90 . Southern.

"This is an uncommon species on our coast, but is occasionally met with in company with allied species." 


\section{Family GERRIDa.}

Mouth very protractile, descending when protruded; no supplementary maxillary ; spine from premaxillary ascends to above the eye ; surface of maxillary silvery, like rest of head; base of mandible scaly; teeth villiform; pseudobranchiæ concealed.

\section{GERRES, Ouv.}

G. gula, Cuv. \& Val. (Diapterus, Eucinostomus argenteus.) .

Silvery, without spots or streaks; young sometimes barred; mouth small; scales large; soft dorsal extends further back than usual; second spines of dorsal and anal only a little enlarged; soft and spiny part of dorsal of similar extent ; preopercle entire; anterior part of premaxillary groove on top of head, scaled. Dorsal rays, IX, 10 ; anal rays, III, 7 ; scales, $4-45-9$; depth two-fifths of length; third dorsal spine twice the length of second anal.

"This species was first made known by Prof. Baird in 1854, he having taken specimens at Beesley's Point. The writer has seen many specimens from the same locality, and from South Amboy, Atlantic City, \&c. They are most abundant in September and later, until winter."-[C. C. A.]

G. homonymus, G. \& B. (Diapterus, Eucinostomus argenteus.)

Silvery, brownish above, center of scales with a dark spot; a spot on spinous dorsal; young with transverse bars; depth half of length ; third dorsal spine about equal to second anal. Dorsal rays, IX, 10 ; anal rays, III, 8 ; lateral-line scales, 40 ; otherwise like preceding. Atlantic coast. Abundant southward.

\section{Family LABRIDE.}

Wrasse-fishes.

Pseudobranchs well developed ; slit behind last gill small or obsolete; scales cycloid; no supplemental maxillaries; premaxillaries moderately protractile; teeth strong, often soldered together into 
plates; lower pharyngeals completely united into one without median suture; lips thick and plicate; ventrals thoracic; most feed on mollusks, having teeth adapted for crushing shells.

\section{CTENOLABRUS, Ouv. \& Val.}

C. adspersus, Walb. (Tautogolabrus, Labrus, burgall, coruleus.) Cunner. Chogset. Blue Perch. Bergall.

Pharyngeal teeth not confluent; teeth all conical, set in a band; the outer enlarged; no posterior canines; body slender, compressed; head pointed; cheeks with small scales, opercles with large ones; preopercle serrate; lateral line abruptly bent near posterior part of dorsal ; spiny part of dorsal the longer; anal spines strong; pectorals short; color brownish blue, with brassy luster; young variegated with black blotch on dorsal. Dorsal rays, XVIII, 10 ; anal rays, III, 9 ; lateral-line scales, 45 ; length, 12 inches.

"This is a numerous species, found about the coast generally, and not prized as an article of food. It has many common names, as ' nibbler,' ' conner,' \&c."

HIATULA, Lac.

(Tautoga, Mitch.)

H. onitis, L. (Labrus, americana, gardeniana, hiatula.) Blackfish. Tautog. Oyster-fish.

Preopercle entire; cheeks scaly, but opercles naked; teeth in two series, strongest in front; eye small, high up; head large; mouth small; dorsal low and long; spines with cutaneous appendage at tip; caudal short and truncate; branchiostegals five; color blackish ; young greenish, with three pairs of irregular, chain-like bars; pectorals short. Dorsal rays, XVI, 10; anal rays, III, 8 ; lateral-line scales, 60.

"Found more or less abundant along the coast during the summer and autumn. They are prized as a market fish, and are brought to the various towns of the State throughout the winter. They occasionally are found in the rivers where the water has ceased to be brackish." 


\section{Family EPHIPPID 2 .}

\section{Angel-fishes.}

Dorsal fin divided; vertical fins scaly; teeth bristle-like, in many rows; gill openings restricted to sides; body compressed, greatly elevated, with steep profile; scales ctenoid ; mouth small ; premaxillaries protractile; maxillary short, without supplemental bone; preopercle usually finely serrate; pectorals short and ventrals long, thoracic $(I, 5)$; air-bladder large, often forked in front and with two slender horns behind.

\section{CHATODIPTERUS, Lac.}

(Parephippus, Gill.)

C. faber, Brouss (Chætodon, Ephippus, Zeus, quadratus, gigas, zonatus). Angel-fish. Porgee.

Grayish, dusky band across eye to throat; similar bands on body, obscured with age; ventrals black; third dorsal spine prolonged; a row of pores on chin; body nearly orbicular in outline, much compressed; scales small. Dorsal rays, VIIII, 20 ; anal rays, III, 18 ; lateral-line scales, 60 ; length, 2 feet. Excellent for food.

"This peculiar fish is met with during the summer on our coast, but never abundantly; and during some seasons it does not make its appearance." Old individuals of large size, without bands, and with thick, bony masses on occipital crest, \&c., have by some been considered to be distinct species, as follows:

"Ephippus gigas.

"Has been caught in the Hudson River. Very rare."

\section{Family CHATODONTID五.}

Differs from last family in having the dorsal fin continuous; pseudobranchs very large; colors bright. 
POMAOANTHUS, Lac.

(Chrtodon. Holacanthus.)

P. ciliaris, L. Angel-fish. Isabelita.

Preoperculum with a strong spine at its angle; brownish olive; each scale with a crescent of lighter shade; nape with a dark-brown spot, enclosing blue center; cobalt-blue markings on various fins, spines, \&c.; yellow also on fins; scales ciliate; soft dorsal and anal with anterior rays prolonged as long streamers. Dorsal rays, "XIV, 20 ; anal rays, III, 20 ; scales, $8-$ $50-30$.

"This beautiful species is seldom. met with along our coast. A specimen is in the Philadelphia Academy's museum, that was taken in Delaware Bay. It is a southern species."

\section{Family ACANTHURIDE.}

(Teuthidœ.)

\section{Surgeons.}

Teeth in one row, incisor-like; tail with one or more movable spines or bony plates on each side; mouth small, low; eye high up; premaxillaries movable, but not protractile; gill rakers obsolete; a gill slit behind fourth arch; gill openings restricted to the sides; pelvic bone long; ventrals thoracic. Herbivorous fishes.

\section{ACANTEURUS, Bl. \& Schn.}

(Acronurus, Gunth.)

A. nigricans, L. (Chætodon, phlebotomus.) Surgeon-fish.

A movable, lancet-like spine on each side of tail ; body ovateoblong, covered with minute ctenoid scales; operculum short; branchiostegals five; vertebræ, $9+13$; color brownish ; opercle with a black margin; sides with very narrow transverse bands; body not much elevated; profile somewhat convex and snout longish ; fins high; caudal emarginate. Dorsal rays, IX, 25 ; anal rays, III, 23.

"This species is very rare upon our coast, and can only be 
looked upon as an occasional visitor. A single specimen has been seen, taken at Tuckerton in 1860."

These species are West Indian, and only rarely come northward. A. chirurgus differs from preceding in having a less convex profile, shorter snout, vertical bars on sides wider, and vertical fins with oblique streaks. Besides this, there is the "blue surgeon," A. cceruleus, marked with bluish lines; profile concave, caudal forked, and body very deep; soft rays two or three more. A form more like nigricans is A. tractus, distinguished by deeply-forked caudal, with long upper lobe, which ends in a white thread; fins, but not body, streaked.

\section{Family URATOSCOPIDE.}

Star-gazers.

Anal fin elongate; pectorals broad; eyes small, on top of front of head; body terete, largest at back of head; scales small, in oblique series; lateral line feeble; mouth vertical; lips fringed; premaxillaries protractile; gill openings wide; branchiostegals six ; gills three and a half, a small slit behind last. Carnivorous fishes, living on sea-bottom.

\section{ASTROSOOPUS, Brev.}

(Agnus. Upselonphorus.)

A. anoplus, Cuv. \& Val. (guttatus-Abbott's Catalogue.) Star-gazer.

Mouth large; teeth of jaws depressible; nostrils fringed; a $Y$-shaped projection on top of head; a naked space in front of the $\mathrm{Y}$, between eyes; belly mostly naked; sides with fine scales; brownish, covered with small white spots; caudal striped; a broad, naked, electric area on each side of the $Y$. Dorsal rays, IV-13; anal rays, 12 ; lateral-line scales, $113 . \quad$ Young said to be naked.

"This species is not abundant, but is generally to be found if hunted for, from Navesink to Cape May."

The following is evidently a stage in the growth of the preceding : 
"Upsilonphorus guttatus. Star-gazer.

"This species is about as abundant as the preceding, and for some time was confounded with it. The first description and figure published was by the writer, in the Proceedings of the Philadelphia Academy of Natural Sciences, 1860."-[C. C. A.]

\section{Family GOBIIDE.}

\section{The Gobies.}

Gill openings restricted to the sides; no lateral line; body not elevated; spinous dorsal weak ; inner rays of ventrals longest; premaxillaries protractile; usually no air-bladder. Carnivorous fishes, living on the bottom, usually, of warm seas.

\section{GOBIOSOMA, Grd.}

(Gobius, L.)

G. bosci, Lac. (alepidotum, Schn.) Goby.

Body naked; no canines; teeth in bands; ventral fins united; body oblong, depressed in front, compressed behind; eyes high, anterior, close together; color olive brown, with seven to eight paler transverse bars; caudal fin pointed and with curved bars; mouth small. Dorsal rays, VII-14; anal rays, 11.

"This is a very rare fish along the coast of New Jersey. Isolated specimens are occasionally met with in the bays and inlets, and one was taken in 1867. in Delaware Bay."

\section{Family SCORP EENIDE.}

\section{Rockfishes,}

Suborbital, with a bony stay (" cottoid" character); body elongate, compressed behind; head large, often with spiny ridges; opercles with spines (five on preopercle, two on opercle); gill openings wide; ventrals thoracic, with branched rays ( $I, 5)$. Many of this family are viviparous. 
SEBASTES, Cuv.

S. marinus, L. (Perca norwegicus.) Red Sea Perch. Redfish. Rosefish.

Snapper. Hemdurgan.

Orange red, sometimes with vague dusky bars; back elevated; belly profile nearly straight; top of head evenly scaled; concave between two low interorbital ridges ; nasal spines present; opercular spines long and sharp; eye very large; mouth large, oblique; tip of. lower jaw projecting; pseudobranchs large; caudal fin narrow and forked; scales weakly ctenoid; vertebræ, $12+19$; palatine teeth present. Dorsal rays, XV-13; anal rays, III, 7 ; lateral-line scales, 85 ; tubes, 40 . North Atlantic; south to Cape Cod.

"A specimen of this northern species was taken off Sandy Hook in August, 1865, and presented to the writer." - [C. C. A.]

The following is a littoral variety or sub-species of the above having similar range :

Subsp. viviparus, $\cdot$ Kröyer.

Brownish red, mottled, with black blotch on opercle, and brown spots on body; pectorals a little longer, body smaller.

\section{Family COTTID五.}

\section{Sculpins.}

Head broad, depressed; body tapering backward; eyes high up and close together; a bony stay connects suborbital and preopercle; upper angle of preopercle with spines; body never uniformly scaled ; caudal rounded; air-bladder usually wanting.

\section{HEMITRIPTERUS, Cuv.}

H. americanus, Gmel. (Scorpæna, Cottus, acadianus.) Sea Raven.

Spinous dorsal deeply notched, anterior spines highest; skin rough with prickles, \&c. ; teeth on vomer and palatines; no slit behind last gill; head large, uneven; mouth very wide; preopercle with blunt spines; color reddish brown, marbled with darker and variegated; yellow below ; prickles on back tubercle- 
like; two occipital spines on each side. Dorsal rays, IV, XII -I, 12 ; anal rays, 13 ; lateral-line scales, 40.

"An occasional specimen met with, but the species appears in our waters only as a straggler."

\section{URANIDEA, De K.}

(Cottus. Cottopsis.)

U. richardsoni, Ag., var. meridionalis, Grd. Miller's Thumb. Blob. Muffle-jaw. Bullhead. Fresh-water. Sculpin. Litțle Stargazer.

Body fusiform; head feebly armed; no slit behind fourth gill; branchiostegals six; dorsals nearly separate; skin mostly smooth; preopercular spine sharp and directed upward, and more or less concealed by skin; below this, two small spines; palatines with teeth; olivaceous, barred or speckled with darker, especially on fins; body relatively robust, tapering backwards; first dorsal low ; pectorals long. Dorsal rays, VI to VIII-16 or 17 ; anal rays, about 12 ; length, 3 to 7 inches. Abundant in Pennsylvania.

The following is also found in Pennsylvania :

U. viscosa, Hald.

Palatine teeth obsolete; ventrals, I, 3; anals, 14 or 15; spinous dorsal edged with orange; body stout, with many mucous pores on head; mouth small. Dorsal rays, VI-18.

The following is abundant in New York:

U. gracilis, Heckel (gobio, quiescens.)

Anal rays, 11 or 12 ; upper edge of spinous dorsal red in life; body slender, fusiform; preocular spine concealed; mouth large. Dorsal rays, VIII-16.

\section{COTTUS, L.}

(Acanthocottus, Grd.)

C. octodecimspinosus, Mitch. (A. virginianus.) Bullhead.

Body slender, covered with thick skin, without true scales; head large; villiform teeth on jaws and vomer, none on palatines; preopercle with two strong, straight spines above and one below; color olivaceous, with transverse bars; fins barred and mottled; ventrals plain; tail very slender; head long and nar- 
row; upper preopercular spine more than four times as long as the spine next below; occipital ridges end in spines; eye large ; vertex flat; a series of concealed plates along lateral line; spinous higher than soft dorsal; no slit behind last gill. Dorsal rays, IX-15; anal rays, 14.

"This species does not appear to be abundant in our waters, although met with along our whole extent of sea-board."

O. æneus, Mitch. (mitchilli, Gunth.) Grubby. Least Sculpin.

Grayish olive, much variegated with darker, no paler spots; broad, dark bars on back and sides and fins; belly pale; head broad ; preopercular spine about twice as long as next one below. Dorsal rays, IX-13; anal rays, 10 ; length, 6 inches.

"This is a much more numerous species than the preceding."

The following is a variety of this species:

"Acanthocottus mitchilli. Sculpin.

"Not as abundant as the preceding" (aneus).

\section{Family AGONIDE.}

\section{Alligator-fishes.}

Body elongate, angular, with a coat of mail of eight rows of bony. plates; head externally entirely bony; eyes large, high up; mouth low, often with barbels; teeth small, in villiform bands; gills three and one-half, no slit behind last; pseudobranchs very large; ventrals thoracic (I, 2 or 3$)$; spinous dorsal small; caudal narrow; no airbladder. Feed mainly on Crustacea.

\section{ASPIDOPHOROIDES, Lac. \\ (Cottus. Anoplagonus.)}

A. monopterygius, Bloch.

No spinous dorsal ; body very long and slender, tapering to a six-sided tail, which forms two-fifths of whole length; plates keeled, not spiny; fins small; nasal spines very strong; color brownish, obscurely banded with darker; fins mottled; head triangular, narrowed in front. Dorsal rays, 5; anal rays, 6 ; length, 6 inches. North Atlantic.

"A specimen was taken off Sandy Hook in the summer of 1864." 


\title{
Family TRIGLID王.
}

\section{Gurnards.}

Differs from preceding family in having ventrals far apart and more rayed ( $I, 4$ or 5$)$; plates on head armed with spines; a large slit behind fourth gill ; spinous dorsal present ; caudal narrow; pectorals large.

\section{PRIONOTUS, Lac.}

\author{
(Trigla, L.)
}

P. palmipes, Mitch. (Ornichthys, pilatus, carolinus.) Spiny Gurnard. Sea Robin.

Snout broad, flat; eyes close together, high up; head bony, rough; body scaly; opercles with spines, teeth on jaws, vomer and palatines; pectoral with three lower rays detached and thickened at tips; body robust, brownish above, clouded; throat dark; a distinct black blotch on spiny dorsal and with light streaks; pectorals short; mouth small. Dorsal rays, $\mathrm{X}-13$; anal rays, 12 ; lateral-line scales, 58.

"This is an abundant species, found generally along the coast."

P. tribulus, Cuv. \& Val.

Mouth large; sides with spots; belly pale; blotch on spiny dorsal not ocellated; pectorals with bars, detached rays tapering; head shorter and broader than in next. Dorsal rays, $X, 12$; anal rays, 11 ; lateral-line scales, 50 . South Atlantic of United States. Rarer in our latitude.

P. sarritor, L. (evolans.)

Similar to $P$. strigatus (lineatus), but spotted also with white; pectorals black, with pale edgings longer ; body and head stouter, plates rougher and scales larger, in about fifty-five series. Atlantic coast. Common southward.

P. strigatus, Cuv. \& Val. (lineatus.) Flying-fish.

Olive brown above, mottled and spotted with blackish; whitish below ; a narrow black streak on lateral line and a broader one below it, ending behind in dots; lower jaw sometimes orange; pectorals black and orange and dark lines; black 
blotches on dorsal; ventrals and anals orange. Dorsal rays, $\mathrm{X}$, 12 ; anal rays, 11 ; lateral-line scales, 60.

"This species is not abundant on our coast, although met with every summer by collectors."

\section{OEPHALACANTHUS, Lac.}

(Dactylopterus.)

C. volitans, L. (Gasterosteus spinarella, L.) Flying Gurnard.

Head blunt, quadrangular; body tapering backward; bones on top of head united into a shield, prolonged backward as two ridges to dorsal; preorbitals form a projecting roof above jaws; a long, rough spine on preopercle; cheeks and opercles with small scales; mouth small; no teeth on vomer and palatines; scales keeled; two knife-like, serrated appendages at base of tail; pectorals in two parts, the anterior of six rays about as long as head, the posterior large, and reaching nearly to caudal in the adult; air-bladder with two lateral parts ; vertebræ, $9+$ 13 ; color greenish brown and olive, paler below, marked with red and yellow; blue on pectorals; brownish-red markings on caudal; variable. Dorsal rays, II-IV, 8; anal rays, 6; length, 12 inches. Can fly like true flying-fish, but not so far.

"Although not numerous, this fish is well known to the shore fishermen. Specimens are met with along the coast and in our bays, and occasionally in the river's mouth, beyond the reach of strictly sea-water."

\section{Family CYCLOPTERID}

\section{Lump Suckers.}

Body short and thick; mouth small ; teeth slender, in bands, none on vomer or palatines; gill openings on sides, narrow; dorsal long, spiny in front, hidden by a fleshy lump in the adult; ventrals thoracic, rudimentary, forming the center of a sucking disk. 


\section{CYCLOPTERIS, L.}

O. lumpus, L. (Lumpus anglorum, De K.) Lumpfish. Lump Sucker.

Ventral disk small; head heavy, nearly round; skin with tubercles and seven rows of spiny plates; olivaceous, with darker markings. Dorsal rays, VII-10; anal rays, 10.

"This species belongs to the northern seas, and is very seldom met with as far south as the coast of New Jersey. A specimen taken at Sandy Hook in 1866, warrants our placing it in the State's fauna."

\section{Family Batrachidz.}

\section{Toadfishes.}

Body robust, depressed in front, compressed behind; head large, with mucous channels; mouth very large, with strong teeth; pseudobranchs none; ventrals large, jugular.

\section{BATRACHUS, Bl. \& Schn.}

B. tau, L. Toadfish. Sarpo. Oyster-fish.

Body scaleless; no lateral line; young with tufted cirri on back and sides; color dusky olive, with irregular bars on sides, \&c.; belly lighter ; fins barred; teeth largest posteriorly ; tip of snout with cirri ; subopercle ends in a long, sharp spine. Dorsal rays, III-27; anal rays, 24.

"This unattractive fish is.very abundant along our coast, and is to be met with outside the beach, and never or very seldom in the inlets or bays.

"The flesh is said by those who have been able to overcome their aversion to the fish, to be very sweet and palatable."

\section{Family BLENNID王.}

\section{Blennies.}

Body oblong ; cheeks not mailed ; ventrals jugular ; caudal rounded, diphycercal; air-bladder usually wanting. 


\section{OHASMODES, Cuv. \& Val.}

(Blennius.)

C. bosquianus, Lac. (Pholis, novemlineatus.)

Body naked; head triangular in profile, with pointed snout; mouth large; premaxillaries not protractile; teeth in one row, long and comb-like; gill openings very small; color in male olive green, with three horizontal, narrow blue lines; orange opercle and a stripe through spinous dorsal; anal fin dark rays with white tips; in female, head dotted with black; dark bars and narrow green lines on body. Dorsal rays, XI, 19; anal rays, 20. Rare on our coast; abundant southward.

"The writer has never met with a species of this fish; said to be an inhabitant of our range of coast."

\section{BLENNIUS, L.}

B. fucorum, Cuv. \& Val. Blenny.

Body oblong, compressed, naked; head short, profile rounded ; mouth small, with one series of long, close-set, curved teeth; strong canines in both jaws; gill openings wide; color olive green, darker above, with numerous brown spots on cheeks and on sides of body; below faintly reddish ; orbital cirri nearly as long as head. Dorsal rays, XI, 17 ; anal rays, 18.

"Not unfrequently met with out at sea, but does not appear to be abundant in the ocean, and less so along the coast."

\section{MUR AN NOIDES, Lac.}

(Centronotus, Bloch.)

M. gunnellus, L. (Blennius, Ophidium mucronatum, Gunnellus macrocephalus, \&c.) Butter-fish.

Body band shaped; head small ; scales small ; no lateral line; dorsal long and low, composed of spines; anal has two spines; caudal small; ventrals rudimentary; color olive brown; sides with obscure bars; ocellated spots at base of dorsal; mouth oblique. Dorsal rays, LXXVIII ; anal rays, II, 38 ; vertebræ, 85 ; length, 12 inches.

"This species is abundant in New York Harbor, and is less numerous as we proceed down the coast of our State. Specimens have been taken in Delaware Bay." 


\section{ANARRHIOHAS, L.}

A. lupus, L. (vomerinus, Stor.) Wolf-fish.

Body elongate, covered with rudimentary scales; head compressed, scaleless, narrow above profile; decurved strongly; mouth wide, oblique; jaws with strong teeth in front; vomer thick, with two series of molars; palatines similarly; no lateral line; dorsal all spines, high; no ventrals; pectorals broad, low down; color brown, with nine to twelve dark bars on sides, also spots, \&c.; fins dark ; caudal tipped with reddish. Dorsal rays, LXII; anal rays, 42.

"Not unfrequently met with, but they are nowhere along our coast abundant."

\section{Family LYCODIDAE.}

\section{Eelpouts.}

Body eel shaped; head large; mouth large, with conical teeth; bones of head unarmed; pseudobranchs present; dorsal and anal fins very long, without spines, not separate from caudal ; pectorals small ; ventrals rudimentary, jugular; lateral line nearly or quite obsolete; viviparous, living on bottom of sea.

\section{ZOARCES, CuV.}

Z. anguillaris, Peck (Enchelyopus, labrosus, fimbriatus; Blennius ciliatus, the large-mouthed variety). Eelpout. Mutton-fish. Mother of Eels. Conger Eelpout.

Reddish brown, mottled with olive; dorsal marked with darker; pectorals two-thirds length of head; ventrals one-fifth head; some short spines in posterior part of dorsal. Dorsal rays, 95, XVIII, 17 ; anal rays, 105 ; length 20 inches. Anguillaris and ciliatus are by some treated as distinct species.

"Quite abundant in early spring, found associated with the common cod." 


\section{Family OPHIDIID}

Body compressed, eel shaped, with small scales in oblique series; head large; gill openings wide; pseudobranch rudimentary ; caudal isocercal, confluent, with long, non-spined vertical fins.

\section{OPHIDIUM, L.}

O. marginatum, De K.

Scales not imbricated; head nearly naked; teeth on vomer and palatines blunt, on jaws fixed, for the outer series; color brownish; vertical fins margined with black; air-bladder short, with foramen below.

"Rare. Prof. Baird reports a specimen taken at Beesley's Point."

\section{Family GADID}

\section{Codfishes.}

Body elongated, compressed behind; tail usually isocercal; scales cycloid, small ; gill openings very wide ; no spines; dorsal very long, often divided; ventrals jugular; no pseudobranchs.

ONOS, Risso (Ayres).

(Motella. Rhinonemus.)

O. cimbrius, L. (M. caudacuta.) Four-bearded Rockling.

Brownish; posterior part of vertical fins abruptly black, also inside of mouth ; snout high ; mouth large, four barbels; lateral line interrupted at intervals ; first ray of dorsal free and as long as head; no canines; dorsals two. Dorsal rays, 50 ; anal rays, 43 ; ventral rays, 5 ; length, 12 inches. North Atlantic.

\section{PHYCIS, Bl. \& Schn.}

P. regius, Walb. (Blennius, punctatus, Enchelyopus, regalis, Urophycis, Gill.) Spotted Codling.

Brownish and yellow; lateral line brown, with white spots; inside of mouth white; first dorsal black, edged with white; 
second dorsal spotted; pectorals dusky; ventrals white; sides of head spotted; body stout; mouth large; barbel on chin; palatines toothless; dorsals two; ventrals filamentous, separated. Dorsal rays, 8-43; anal rays, 45 ; lateral-line scales, 90 . Said to be electric.

" Rare. The writer knows it only from the work of De Kay." - [C. C. A.]

P._chuss, Walb. (Blennius, Enchelyopus americanus, filamentosus.) Ling. Codling. Squirrel-hake.

Brownish above; sides tinged with yellow, and punctulate with darker; lateral line not dark; body slender; eye large; first ray of dorsal filamentous, two-sevenths as long as body; ventrals long. Dorsal rays, $9-57$; anal rays, 50 ; lateral-line scales, 110.

"This is seldom met with along our coast, although very abundant northward. A specimen was taken in Delaware Bay, at Salem, N. J., in 1867."

P. tenuis, Mitch. (dekayi, Gadus.) Codling. White Hake. Squirrelhake.

Body lighter below; fins very dark; snout longer and narrower than preceding; filamentous dorsal ray two-thirds length of head; scales much smaller than in preceding. Dorsal rays, $9-57$; anal rays, 48 ; lateral-line scales, 138 . With the preceding.

\section{BROSMIUS, Cuv.}

B. brosme, Müll. (Gadus, flavescens, vulgaris.) Cusk.

Brownish, mottled ; young uniform slate color, or with transverse yellow bands; vertical fins black, white bordered; upper jaw longer; head flattened; scales very small; chin with a barbel ; branchiostegals seven ; dorsal continuous (98 rayss); anal rays, 71 .

"A rare species that is only met with as a straggler. The writer has seen but two, both from Cape May."

\section{GADUS, L.}

G. æglifinus, L. (Melanogrammus, Gill.) Haddock.

Dark gray above, whitish below; lateral line black; a dark blotch above pectorals; dorsal and caudal dusky; snout long 
and narrow, overlapping small mouth; teeth strong, in one row in lower jaw, and in band in upper; occipnt with a high crest; eye very large; skull depressed, thinner in texture and broader as compared with next; anterior rays of first dorsal elevated; second dorsal over vent; caudal lunate; scales very small; chin with a barbel ; three dorsals and two anals; ventrals well developed, seven rays. Dorsal rays, 15-24-21; anal rays, 23-21.

"This is a very common species, offered for sale in large numbers in our markets, and when fresh is a moderately good fish for the table."

G. callarias, L. (morrhua, Morrhua americana, macrocephalus, ogak, auratus.) Common Codfish.

Lateral line pale; mouth large; color greenish brown (variable), sometimes yellowish or reddish, with many round brown spots ; fins dark; occipital crest moderate; teeth in lower jaw, in band, the inner ones enlarged. Dorsal rays, 14-21-19; anal rays, 20-18. Many varieties; dependent on locality.

"The cod is not by any means as common on our coast as farther north, but yet it is sufficiently abundant about several bars, as off Barnegat, and affords most excellent fishing. Fresh cod from Barnegat are offered for sale in Trenton market, in large quantities."

G. tomcod, Walb. (Microgadus, Morrhua pruinosa.) Tomcod. Frostfish.

Olive brown, blotched with darker; back and sides punctulate; snout rounded ; mouth short; barbel small; ventrals filamentous, not reaching vent; second dorsal behind vent. Dorsal rays, 13-17-18; anal rays, 20-17; length, 11 inches.

"This is a very common little fish, more or less abundant throughout the year. As an article of food they are of little value."

G. virøns, L. (carbonarius, Pollachius, Merlangus purpureus.) Pollack. Green Cod. Coalfish.

Greenish brown; silvery below; lateral line and fins pale; body elongate, compressed; snout sharp, conic ; mouth oblique ; teeth nearly equal ; barbel rudimentary ; vent under first dorsal ; pectorals and ventrals short; lower jaw projecting. Dorsal rays, 13-22-20; anal rays, 25-20; lateral-line scales, 150; vertebræ, 54 . 
"This is not a common species on our coast, and when met with is associated with allied species. As an article of food they are not much prized."

\title{
MERLUCIUS, Raf.
}

M. bilinearis, Mitch. (Stomodon, Gadus, albidus.) Hake.

Grayish ; darker above, silvery below ; inside of mouth dusky blue; top of head with $\mathrm{W}$-shaped ridges; teeth not very large; pectorals and ventrals long; scales larger than in allied species; excavation on forehead; eye somewhat large; edge of preopercle free; mouth large, oblique; lower jaw longer, with slender teeth in two series, the inner movable, no barbel; branchiostegals seven; second dorsal and anal deeply emarginate. Dorsal rays, $13+41$; anal rays, 40 ; lateral-line scales, 100 to 110 . Large and voracious. Of little value for food.

"A rare species, that is, as an apparent straggler, found associated with the common cod and the haddock."

\section{Order heterosomata.}

\author{
Flat Fishes.
}

\section{Family PLEURONECTIDE.}

\section{Flonnders.}

Cranium anteriorly twisted to allow both eyes on one side; dorsal long; body very flat, oval in outline; blind side plain and lowermost; cranium symmetrical in young, becoming twisted during development, and at same time the horizontal position of body is assumed; sometimes one eye moves through the cranium to reach the opposite side; no air-bladder; vent near head; scales small; lateral line usually extends on to caudal fin; pectorals and ventrals near together. 


\section{. BOTHUS, Raf. \\ (Rhombus. Pleuronectes.)}

B. maculatus, Mitch. (aquosus, Lophopsetta.) Spotted Turbot. Sand Flounder. Window-pane.

Light olive brown, nearly translucent, marbled with paler, and with blackish blotches; body rhomboid; eye large; mouth large; teeth in one lateral series in both jaws; scales well-developed cycloid; no bony tubercles; dorsal and anal scaled ; lateral line arched in front; dorsal begins on snout; left side uppermost. Dorsal rays, 65 ; anal rays, 52 ; lateral-line scales, 85 ; length, 18 inches.

"Occasionally this species is seen in our waters, but it is rare, and only taken associated with allied species."

\section{CITHARICHTHYS, Bleek.}

(Hemirhombus. Metoponops. Orthopsetta.)

O. arctifrons, Goode.

Light brown; body comparatively elongate; scales cycloid, deciduous; lateral line straight; eyes close together; dorsal begins over eye; pectoral on colored side twice the length of other. Dorsal rays, 83; anal rays, 67 ; left pectoral rays, 10 ; right, 7; lateral rays, 40 ; length, 6 inches. Gulf Stream, off Rhode Island; probably referred to in following note, which designates a tropical species :

"Oitharichthys microstomus.

"This is a rare species, met with occasionally, with other flounders, and in its habits generally resembles them." dant.

The following is associated with the preceding, but less abun-

O. unicornis, Goode.

Ashy gray; eyes black; lateral line dark; body deepest over pectorals; strong ridge between eyes, ending in spine on snout; teeth minute, closely set, stronger on blind side. Dorsal rays, 74 ; anal rays, 60 ; right. pectoral rays, 4 ; left, 10 ; lateral-line scales, 40 ; length, 3 inches. 


\section{HIPPOGLOSSUS, Ouv.}

H. vulgaris, Flem. (americanus, Pleuronectes hippoglossus.) Halibut.

Nearly uniform dark brown; blind side white; body deepest mesially, and tapering both ways; eyes large, separated by broad, flat area; eyes and color on right side; teeth in one series in lower, two in upper jaw; scales small, cycloid. Dorsal rays, 105 ; anal rays, 78 ; sometimes reaches a weight of 400 pounds.

"Halibut are seldom taken off the New Jersey coast, but occasionally they are met with in small schools. The markets are generally supplied from northern waters."

\section{PARALICHTHYS, Grd.}

(Chænopsetta, Ancylopsetta and Uropsetta, Gill.)

P. ocellaris, De K. (Platessa, Pseudorhombus, ophryas.) Oblong Flounder.

Brownish gray, mottled; fins dusky, with dark blotches; body elongate, thickish; mouth oblique; teeth in one row, the front ones canine-like; scales very small, not ctenoid, with accessory smaller ones; rather narrow-ridged space between eyes; eyes on left side; lateral line strongly curved anteriorly; caudal doubly concave; both ventrals lateral. Dorsal rays, 88 ; anal rays, 67 ; lateral-line scales, 90. Common from Cape Cod to Florida.

P. dentatus, L. (Pleuronectes, Platessa, Pseudorhombus, Chænopsetta, ocellaris, melanogaster, oblonga.) Common Summer Flounder.

Blackish olive, mottled and blotched with darker; pectorals barred; mouth wide, oblique; mandible heavy and projecting; eight to ten teeth on each side of lower jaw; anterior teeth strong and long; eyes small and not far separated; scales small, cycloid; ventrals small ; fins all scaly. Dorsal rays, 85 to 93 ; anal rays, 65 to 73 ; lateral-line scales, 100 .

"This is a very common species, found everywhere along the coast, especially in warm weather, and is called 'summer flounder.'"

\section{HIPPOGLOSSOIDES, Gotts.}

(Psettichthys. Pomatopsetta.)

H. platessoides, Fabr. (Pleuronectes, dentata.) Rough Dab.

Reddish brown, nearly uniform; upper jaw with one series of teeth ; mouth oblique, with a knob at chin; snout thick, scaled; 
eyes large; interorbital space rough, with scales. Dorsal rays, 80 to 93 ; anal rays, 64 to 75 ; 90 pores in lateral line. North Atlantic; abundant northward. The southern variety (limandoides) has a smaller number of fin rays.

\section{PLEURONECTES, L.}

P. ferrugineus, Stor. (Limauda, Platessa, Myzopsetta, rostrata.) Sand Dab. Fluke.

Lateral line arched in front; scales ctenoid; a strong anal spine; body ovate-elliptical, very flat, brownish olive, with many red spots; left side lemon yellow; teeth small, conical, close set, in one series; snout projecting; eyes separated by a high, narrow ridge; eyes on right side. Dorsal rays, 85 ; anal rays, 62 ; lateral lines, 100.

"This is a rare ocean-loving species, that is met with occasionally associated with the preceding."

P. glaber, Stor. (Platessa, Liopsetta, Euchalarodus putnami.) Plaice.

Grayish brown, mottled with darker; black spots on fins; body oblong; eyes small, separated by a naked ridge; jaws with interrupted series of twenty incisor-like teeth, besides an inner row sometimes; right side of both jaws toothless; scales small, not imbricate, cycloid in female, ctenoid in male; anal spine present; lower pharyngeals broad, with paved teeth. Dorsal rays, 55; anal rays, 40 ; lateral line, 70 pores; length, 10 inches. Atlantic coast, chiefly northward.

P. americanus, Walb. (Pseudopleuronectes, Bleek.) Common Winter Flounder. Mud Dab.

Dark, rusty brown, spotted or nearly plain; young more olive and spotted; body elliptical ; head eovered above like body, with imbricated ctenoid scales; blind side of head nearly naked; eyes well separated; teeth close set, incisor-like; right side of both jaws toothless. Dorsal rays, 65; anal rays, 48 ; lateralline scales, 83.

"This species is quite common along our coast generally, and is deservedly prized as an article of food. They are generally exposed for sale in the fish-markets, and are usually known as the "winter flounder." " 


\section{ACHIRUS, Lac.}

A. lineatus, L. (mollis, Pleuronectes, lineatus, Solea, achirus.) Sole.

Olive brown, with six narrow, vertical, black lines and numerous spots and clouds; left side white, mottled or barred; form oval; scales on chin, \&c., three or four times size of others; fins scaly on both sides; nostril of blind side and lip of colored side fringed; teeth small, on blind side only; head scaled; no anal spine; both pectorals absent. Dorsal rays, 55 ; anal rays, 41 ; lateral-line scales, 75 ; length, 6 inches.

"This little species is abundant along our coast and in the various bays and inlets. Although much more abundant during the spring and summer, they are met with throughout the year. They are known at Beesley's Point as the 'hog-choker.'"

\section{Order Pediculati.}

Carpal bones of pectorals elongate, forming a sort of arm; gill openings reduced to a foramen, more or less posterior to the pectorals; ventrals, if present, jugular; no scales; first vertebra united to cranium ; no interclavicles.

\section{Family LOPHIIDE.}

\section{Fishing-frogs.}

Head wide, large, depressed; body tapering rapidly backward; mouth very large, opening into an enormous stomach; upper jaw protractile, lowtr projecting; teeth in both jaws strong and unequal; gill openings comparatively large in lower axil of pectorals ; pseudobranchs present; no gill rakers; spinous dorsal of three tentaclelike spines on head and three smaller ones behind; ventrals far apart.

\section{LOPHIUS, L.}

L. piscatorius, L. (americanus.) Angler. Fishing-frog. Monkfish. Goosefish. Allmouth. Bellows-fish.

Brownish, mottled; white below; pectorals and caudals black at tip; body scarcely longer than head; head surrounded by a 
fringe of barbels; spines on top of head in young. Soft rays of dorsal and anal, 10 and 9 ; length, 3 feet.

"This species is quite common along our coast. It is occasionally found in the Delaware River, in the vicinity of fresh water."

\section{Family aNTENARRIIDza.}

\section{Frog-fishes.}

Mouth oblique, almost vertical; gill openings small, pore-like; pectorals with elbow; ventrals near together; dorsal with three tentacular spines; can float by inflating stomaeh.

\section{PTEROPHRYNOIDES, Gill.}

(Antennarius, Lac.)

P. histrio, L. (Lophius, Pterophryne, A. marmoratus, Chironectes lavigatus.) Mousefish. Toadfish.

Body compressed, deep through occiput; mouth oblique; ventrals long; skin with fleshy tags; eye small; first dorsal spine tentaculate, second and third covered with fleshy filaments; soft dorsal high and long; anal short; color yellowish, marbled with brown; three hands from eye; vertical fins barred; white spots below. Dorsal rays, 14 ; anal rays, 7 ; ventral rays, 5 . Tropical; occasionally northward. Different varieties referred to as different species in the two following of C. C. A.:

"Antennarius variegatus. Mousefish.

"Not common. The writer has seen but a single specimen, which was taken at Beesley's Point.

"Antennarius gibbus. Mousefish.

"Specimens of this species are more frequently met with than are the preceding."

\section{Family MALTHID 2 ב.}

Batfishes.

Head depressed and broad, with elevated snout and short, slender trunk ; mouth not large; gill openings behind upper part of pectorals ; 
body and head covered with bony tubercles and spines; spinous dorsal reduced to a small retractile tentacle on head; angle in pectorals near base; branchiostegals five.

\section{MALTHE, Cuv.}

(Lophius, L.)

M. vespertilio, L. Batfish.

Pale grayish brown above, reddish below ; forehead produced into a conical process. Dorsal rays, 4 ; anal rays, 4 ; length, 6 inches. Chiefly southern. (M. cubifrons, associated with this, differs in having a shorter snout and heavier tail.)

"Occasional specimens are no doubt to be met with in our waters, but they have escaped the writer's detection." - [C. C. A.]

\section{Order plectognathi.}

Scapula attached to cranium by a post-temporal; premaxillaries usually united to maxillaries; interoperculum a slender rod; skeleton weakly ossified; vertebræ few; ventrals rudimentary.

\section{Family OSTRACIIDE.}

Trunkfishes.

Body angular, covered by a carapace of firmly-united, six-sided plates; the tail, jaws and fins free, and covered by naked skin; mouth small, with long, narrow teeth; gill opening a slit behind eye; no ribs; anterior vertebræ long, posterior very short.

OSTRAOIUM, L.

(Ostracion. Artedi.)

O. quadricorne, L. Cowfish. Cuckold. Trunkfish.

Brown, yellow, blue or green, with irregular blue blotches; carapace trigonal; adults with a broad, low ridge on each side of back; ventral surface flat; a stout spine over each eye; carapace closed behind dorsal fin and anal. Common in southern waters of Atlantic. Probably referred to in following: 
"Tetrasomus camelinus. Trunkfish.

"The writer has never met with specimens of this fish, except one in a private cabinet, labeled 'Atlantic City, N. J.'"

\section{Family BALISTIDE.}

Trigger-fishes.

Body oblong, covered with rough scales or scutes, not united into a carapace; mouth small, with incisor-like teeth; eye near occiput; gill openings small slits, not behind pectorals; ventrals absent; one to three spines in first dorsal.

\section{BALISTAS, L.}

B. capriscus, Gmel. ( fuliginosus, De K.) Leather Jacket. Filefish.

Brown; second dorsal and anal with lines; caudal mottled and with dots; third dorsal spine stouter, but shorter than second; plates on head like those on body, rough; a groove in front of eye; tail compressed. Dorsal rays, III-27; anal rays, 25 ; lateral-line scales, 51 to 57 . Gulf of Mexico.

"This is a very rare species on our coast, but has been met with at Tuckerton and at Cape May."

\section{MONAOANTHUS, Cuv.}

M. occidentalis, Gunth.

Brownish, mottled with paler; a broad band across middle of abdominal flap; scales small; tail with spines; snout pointed; dorsal spine with two rows of barbs behind; soft rays thirty; abdominal flap greatly developed, with rough scales. West Indies. Occasional on southern coast of United States.

M. hiøpidus, L. (broccus, massachusettensis, setifer, Stephanolepis, Canthorinus, Balistes.) Foolfish. Filefish. Thread Filefish.

Dull greenish, mottled with darker; fins olivaceous and blotched; body deep ; eyes large; dorsal spine barbed; pectorals small; pelvic bone long, ends in a spine; abdominal flap short; each scale with three prickles; no spines on tail. Soft rays, 32, 
first one filamentous in some specimens; length, 6 inches. Referred to in following three species of C. C. A.'s list :

"Canthorinus broccus. Foolfish.

"This is an abundant species, found along our coast generally.

"Canthorinus massachusettensis. Filefish.

"This species is frequently met with during the summer months, along our coast generally.

"Canthorinus segnifer. Thread Filefish.

"Not abundant. Stragglers have been taken at Sandy Hook and at Cape May."

M. pullus, Ranz. (Cantherines, pardalis.)

Hias two pairs of spines on sides of tail ; ventral spine fixed; dorsal without barbs; scales minute; skin velvety. Soft rays, dorsal, 35 ; anal, 31 . Rare north of Florida.

\section{ALUTERA, Ouv.}

(Balister.)

A. schœpffi, Walb. (aurantiacus, cuspicauda, Ceratacanthus.) Unicornfish. Filefish.

Dull green, marbled; lower lip dusky; eye small; gill slit long, below eye; pectorals short; caudal long in young; scales shagreen-like; lower jaw projecting so teeth point obliquely backward; pelvic bones without spine. Soft rays, $36+38$; length, 16 inches. Referred to in following two notes of C. C. A. :

"Alutera cuspicauda. Unicorn-fish.

"This fish is very frequently met with along our coast, and is uniformly abundant from New York to Cape May. They are often abundant in Great Egg Harbor Bay, and many specimens are in the Philadelphia Academy, from Beesley's Point.

"Ceratacanthus aurantiaeus. Orange Filefish.

"This species is only a straggler on our coast, and is very seldom met with. A specimen from Beesley's Point is in the Philadelphia Academy's museum."

A. scripta, Osbeck.

With blue spots and lines and small, round, black spots ; snout long, concave in profile; part of gill opening in front of eye; pectoral below eye; caudal long. Soft rays, dorsal, 46 ; anal, 50. Is rare north of South Carolina. 


\section{Family TETRODONTIDZE.}

\section{Paffers.}

Body broad ; belly capable of great inflation; skin prickly (without scales); teeth confluent, to form sort of beak in each jaw ; lips full; no spines in fins; no ventrals.

\section{LAGOCEPHALUS, Swains. \\ (Gastrophysus.)}

L. lævigatus, L. (Tetrodon.) Tambor. Smooth Puffer.

Olive green; silvery white below ; tail slender ; belly prickly, with spines well separated and equal; sides of tail with folds of skin. Dorsal rays, 14 ; anal rays, 12. Tropics to Cape Cod.

"Only a straggler occasionally of this species is met with in our waters."

\section{TETRODON, L.}

T. turgidus, Mitch. Puffer. Swell-toad. Blower.

Olivaceous above, marbled with black; sides with black bars; a blotch below pectorals; fins plain; profile depressed in front of eyes; skin with three-rooted spines, longest on back and belly; eyes small ; no fold on tail ; only one nasal tube on each side, but with two openings; dorsal and anal short. Dorsal rays, 7 ; anal rays, 6 ; length, 12 inches.

"Specimens of this fish are always to be met with in our coast-waters during the summer. At Atlantic City, in 1864, they were very abundant, and were readily taken with a hook."

\section{TRIOHODIODON, Bleøk.}

\section{T. pilosus, Mitch. (Diodon.) Balloon-fish. Hairy Boxfish.}

Brownish above, ashy below; spines golden; dark oblong spots on sides and above; body cuboid; skin spiny or bristly. Dorsal rays, 12 ; anal rays, 14 . North Atlantic. Rare. Perhaps following refers rather to next (or its young, var. fuliginosus) :

"Diodon pilosus. Balloon-fish.

"This little fish is occasionally met with along our coast, most frequently, however, at the mouth of the Hudson." 


\section{CHILOMYOTERUS, Bibr.}

C. schœpA, Walb. (geometricus, Bl. \& .Schn., Diodon, maculostriatus.)

Rabbit-fish. Spotted Balloon-fish. Swell-toad.

Greenish; belly pale; a round spot above pectorals, several posterior and dorsally; back and sides with black stripes, horizontal and oblique; eyes large; nine spines between eye and: tail ; fins small; spines with three roots (two in Diodon proper). Dorsal rays, 12 ; anal rays, 10 ; length, 6 inches.

"This species is not uncommon along our coast, entering the bays. It is generally met with in summer, and never in cold weather."

Subsp. fuliginosus.

Dark brownish olive, with wavy lines; belly black; bases of its spines orange; probably a young form of preceding.

\section{Family ORTHAGORISCIDZz.}

(Molidæ.)

\section{Headfishes.}

Body short and deep, truncate behind; mouth small; teeth united to form a beak; dorsal and anal confluent around posterior end of body; no ventrals; no pelvic bone; pectorals present; belly not inflatable; no air-bladder. Tropical fishes looking as if "all head," to which fins had been attached.

\section{MOLAOANTHUS, Swains.}

M. nummularis, Walb. (Diodon, Acanthosoma, carinatum, pallasi.) Globefish.

Olive brown above, silvery below; vertically-oval body, higher than long; spines scattered on the deep orbicular body; striated on sides; vertical fins not confluent posteriorly; spines on tail in place of caudal. Dorsal rays, 25 ; length, 2 inches.

"Occasionally met with in our waters, but never abundant. Specimens are preserved in Philadelphia Museum, labeled 'New Jersey." " 


\section{MOLA, Ouv.}

M. mola, L. (rotunda, Cuv., Tetrodon, Orthagoriscus analis.) Head-fish. Sunfish. Mola (a millstone).

Body in young shaped much as in preceding, but becoming longer with age; depth always more than half the length; a "nose" develops with age; skin thick, without spines, but granular; vertical fins high in front, confluent with the low caudal; color dark gray; sides brownish, with silvery; belly dusky; a broad, blackish bar along bases of vertical fins. Dorsal rays, 17 ; anal rays, 16.

"Specimens of this curious species are only occasionally met. The writer found a specimen partially decomposed, on the beach at Barnegat, in November, 1862."-[C. C. A.]

"This concludes the list of the marine and fluviatile species of fish found in the New Jersey waters, with whatever notes the author has made, during his study of their habits, since 1859" (1868). - [C. C. A.]

Note.-It is but just to Dr. Abbott, as well as to the reviser, to add that this Catalogue should have been enriched by the addition of the facts concerning the distribution of the Vertebrates of New Jersey, which have accumulated since 1868 (not incorporated into the general works mentioned in our Introduction); but unfortunately the time needful for this further research too far exceeded the limits set for publication. It is hoped that in its present form, the Catalogue will be more efficient in stimulating accurate observation and in facilitating the gathering and organizing of all scattered information for the use of a future reviser.-Julius Nelson. 


\section{ADDENDA.}

To fucilitate inter-reference between this Catalogue and Jordan's Manual, these Addenda are added, the words being incorporated into the Index.

Page 497. Sorex platyrhinus is common in the Northern United States; $S$. cooperi has nearly the same range. S. personatus ranges from Pennsylvania southward. $S$. hoyi is extra-limital to New Jersey. Blarina angusticeps has been found in Vermont. $\boldsymbol{B}$. parva is common southward from Pennsylvania.

Page 498. Add (americanus, Bartram) as synonym to $\mathbf{S}$. breweri.

Page 501. Add (volans, L.) as synonym to S. volucella.

Page 505. Add (Calomys) as synonym to HESPEROMYs. H. palustris occurs in New Jersey.

Puge 507. The HYSTRICID EE, Porcupines, represented by Erethizon (Cuv.) dorsatus, L., the Canada Porcupine, belong to the extinct fauna of New Jersey.

Page 508. The PHOCIDED, Seals, represented by Phoca (L.) vitulina (L.), the Harbor Seal of the Banks of New Foundland, should be added to the list of occasional visitants.

Page 512. The Raccoons are separated from the other Ursidæ, by Jordan, as a distinct family, Procyonidæ.

Page 514. Add (CETE) as synonym for CETACEA.

Page 515. Add (DENTICeTE) as synonym for ODONTOCETE. Tursiops tursio is abundant at Cape May. Tursiops erebennus, Cope, the Black Dolphin of the Atlantic, may be added to our list of dolphins, though extra-limital. P. plagiodon is occasional on our New Jersey coast.

Page 516. Add (phoczna) to synonymy of P. communis, and Snuffer, Puffing Pig, to common terms.

Page 554. Add (Sylvicolidø) as synonym to MNIOTILTID $\boldsymbol{Z}$.

Page 576. Add Winter Falcon to local names of B. lineatus.

Page 590. The note by C. C. A. accompanying M. scolopaceus properly belongs with M. griseus. 
Page 623. The note by C. C. A. accompanying $\mathbf{P}$. puffinus refers most probably to $\mathbf{P}$. borealis, which is more common, and should properly replace $P$. puffinus in our Catalogue.

Page 624. [P. pelagica] is Procellaria pelagica.

Page 632. Add nigricollis, Brehm, Eared Grebe, to synonomy of C. cristatus.

Page 638. Add (Chelopus, Raf.) to synonymy of NANEMYS.

Page 641. The following Sea Turtles should have appeared in the list of TESTUDINATA： CHELONIIDE, Thalassochelys (Fitzinger); caretta (L.), Loggerhead Turtle; Atlantic, north to Massachusetts. Reaches 400 pounds. DERMOCHELYDID ZE, Dermochelys (Blainv.); coriacea (Vandelli), Leather Turtle, Trunk-back; differs from the former in having no scales on feet.

Page 643. Add "Spreading Adder" to local names of H. platyrhinus. Add (Regina) to synonymy of T. leberis.

Page 649. Add (SAlientia) as synonym to ANURA.

Page 652. Add "Swamp Tree-frog" to O. triseriatus. Add (Pleurodelidø) as synonym to SALAMANDRID $\boldsymbol{Z}$.

Page 653. Add D. nigra (Green), Black Salamander, found in mountain springs of Pennsylvania, to extra-limital faunal list.

Page 654. Add erythronotus as synonym to P. cinereus.

Page 655. AMBLYSTOMATID $\mathbf{A}$ is preferable to AMBIY. STOMIDAE.

Page 656. Extra-limital to New Jersey occur the PROTEIDA family PROTEID $\boldsymbol{Z}$, Mnd Puppies; Necturus (Raf.), maculatus (Raf.), the Water Dog or Mud Puppy, abundant in the great lake region, but also occurring in the Alleghany system. (Menobranchus) is synonym of NEOTURUS. These are salamanders with external gills through life. Sometimes called Water "Lizards."

Page 657. The Amphioxus or Lancelet, a minute sea-fish and the simplest organized of all vertebrates, properly must be included in our List. It forms Class or Sub-Class Leptocardii, Order Cirrostomi, Family Branchiostomatidæ, Genus Branchiostoma (Costa), Species caribæum (Sundevall.) 
Page 658. Add (branchialis) as synonym to $\mathbf{A}$. appendix.

Page 660. Add (Galeorhinidæ) as synonym to CARCHARIID 2 ב. Add (Galeus, Raf.) as synonym to MUSTELUS, Ouv. Add (maculatus, Ranzani) as synonym to G. tigrinus. Add (Carcharinus, Blainv.) as synonym to OARCHARIAS. Add (Lamna) as synonym to $\mathbf{C}$. corruleus.

Page 661. I. limbatus is extra-limital.

Page 662. Add (Squalus) as synonym to O. littoralis.

Page 663. The note by C. C. A., accompanying I. dekayi, refers probably to Lamna (Cuv.), cornubica (Gmel.), Porbeagle, or Mackerel Shark. First dorsal fin close behind pectorals; snout sharp; back elevated. Length, 8 feet. Frequently north to Cape Cod.

Page 666. The Southern Sting Ray, or "Whiparee," Dasyatis sayi (Le S.), is synonym of T. sayi, and is occasional on our coast. To this form, the note by C. C. A, appended to T. centrura, is intended to refer.

Add (bonasus, Mitch.) to R. quadriloba as synonym.

Page 667. Add (Mantidø) as synonym to CEPHALOPTERID Z2. Add (cephaloptera, Rria.) to M. birostris as synonym.

Page 671. AMEIURUS is preferable to AMIURUS.

N. insignis (Rich.) has a flat and thin head with projecting upper jaw, and is perhaps more common than $\mathbf{N}$. gyrinus in our region. The latter is found in the Hudson.

Add (nebulosus, Le S.) to synonymy of A. catus. Closely allied to this form and found in New York is A. melas. Adult very plump; pectoral spines very short.

Page 672. Add (Ameiurus) to synonymy of D. albidus.

Page 673. Add (Tachysurus, Lac., Galeichthys, Cuv.) to synonymy of ARIUS.

Page 676. Add (Pimephales, Raf.) as synonym to HYBOREYNOHUS.

Page 677. HEMITREMIA, CLIOLA, and MINNILUS are sections of genus NOTROPIS in Jordan's Manual.

Page 678. Add (megalops, Notropis) to synonymy of M. cornutus.

Page 679. Add (Kentuckiensis, Raf.) to synonymy of C. biguttatus.

Page 680. Add (Leuciscus) to synonymy of $\mathbf{S}$. bullaris. 


\section{GEOLOGICAL SURVEY OF NEW JERSEY.}

Page 681. Add (Phoxinus, Ag.) to synonymy of Squalius, Bonap.

Page 683. M. atlanticus is occasional in our region.

Page 684. Add (Sadina, Mitch.) as synonym to E. teres

Page 685. Add "Summer Herring," Black-belly, to local names of C. æstivalis.

Page 686. Add (oglinum, Le S.) to synonymy of $\mathbf{O}$. thrissa.

Page 687. Add (Clupeidæ) as synonym to DOROSOMATID

Page 688. Add stolephoridæ as synonym to ENGRAULIDID ZE. Add (argyrophanus, C. \& V., eurystole, Swain \& Meek.), to synonymy of $\mathbf{S}$. perfasciatus.

Add (Synodontidæ) as synonym to SCOPELID 2 .

Page 689. Osmerus is separated from the other Salmonoids by Jordan to constitute family ARGENTINID AE.

Page 693. F. swampinus is a variety of F. majalis. F. nigrofasciatus is a variety of F. heteroclitus.

Page 694. L. parva is also known as Rainwater-fish.

Page 695. Add var. pygmæa to U. limi.

Page 696. Add vermiculatus as synonymous with $E$. umbrosus.

Page 697. A. rostrata may stand as A. anguilla, var. rostrata.

Page 698. Add (Echelus, Raf.) as synonym of LEPTOOFPHALUS.

Page 699. Add (Exocoetidæ) as synonym of SCOMBEROSOCID $\mathbb{E}$. Add (Esox), Silver Gar, to synonymy of T. marinus.

Page 700. The following allies of the flying-fish frequent the ocean in our latitude, besides those noted in the Catalogue: Euleptorhampus (Gill), longirostris (Cuv.) Lower jaw much prolonged; body and pectorals long and slendor. Length, 18 inches. Pelagic; occasional north to Cape Cod. Parexocœtus (Bleek.), mesogaster (Bloch.) Jaws short; roof of mouth with teeth; dorsal fin very high. Length, 6 inches. Pelagic; ranges north to Rhode Island. Exocotus (Artedi), vineiguerræ (Jord.\& Meek.) Anal fin with 11 rays; ventrals black; no black on dorsal fin. Length, 12 inches. Atlantio north to Grand Banks. E. volitans, L. Differs from preceding in having smaller scales (lateral-line scales, 55), and ventrals are nearly white. $\mathbf{E}$. heterurus, Raf. Anal fin short, with 9 rays; white band on pectorals. Lateral-line scales, 58 . Commonest species. 
Page 701. F. exsiliens, Müll., takes precedence of exiliens, Gmel,, as name of this species.

Jordan includes OYPSELURUS in EXOOGTUS. Add (E. gibbifrons) as synonym of $\mathbf{O}$. comatus.

Page 702. Add (S. hippocampus) to synonymy of H. heptagonus.

Page 704. Perhaps G. pungitius and G. biaculeatus are but varieties of $\mathbf{G}$. aculeatus.

Page 706. Add (cephalus) as synonym of M. albula. Add (curema) as synonym of M. brasiliensis (Günth.), not Ag.

Page 709. F. remora is also called Sucking-fish. E. brachyptera is also called Swordfish Remora. R. osteochir is also called Spearfish Remora.

Page 711. TETRAPTURUS may be separated as Family ISTIOPHORID 2 .

T. lepturus is also termed Scabbard-, or Cutlass-fish.

Page 712. S. pneumatophorus is also callẹd Thimble-eye.

Page 713. S. regalis is also called Pintado. Sierra.

Page 714. Add (Albacora) as synonym to ORYONUS.

Page 715. Add (latus) as synonym to O. amblyrhynchus.

Add C. gallus, L. (crinitus, Mitch.), Threadfish, to list of forms occasional in our region. Body very ovate; scales very small; scutes feeble. Length, 2 feet.

Page 716. Add (Scomber) to synonymy of C. hippos.

Page 717. Add Moonfish to local names of S. (or Vomer) setipinnie. Add Bumper, Casabe, to local names of $\mathbf{C}$. chrysurus.

Page 718. Add T. falcatus, L. (ovatus, rhomboides), Round Pompano, Palometa, to list of forms occasional in our limits. Depth of body more than half length.

Page 722. Add Dorado to local names of C. hippurus.

Page 723. Add (Asternotrema) to A. sayanus as synonym.

Page 724. Add (Centrarchus) to $\Delta$. rupestris as synonym.

Page 728. Add (Calliurus) to M. dolomiei as synonym.

Page 729. Add (Oligocephalus) to E. flabellare as synonym. Add (Etheosoma) to P. cæruleus as synonym. 
Page 733. Add (striatus) as synonym to $\mathbf{S}$. nigrescens.

C. furcifer has small scales, covering also jaws and head; snout short; color reddish, with three small violet spots on side of back and one on tail. Tropical.

Page 734. Add (cerna) as synonym to E. morio.

Add "Mangrove Snapper" to local terms of L. caxis.

Page 736. Add (Chrysophrys) to synonymy of $\mathbf{S}$. chrysops.

Page 737. Add (Sparus) to synonymy of $\mathbf{S}$. versicolor.

Page 741. Add (saxatilis) to synonymy of M. nebulosus.

Add (nebulosus) to synonymy of $\mathbf{O}$. maculatum.

Page 742. The GERRID $\boldsymbol{Z}$ include the Moharras.

Page 747. Upsilonphorus (Gill), guttatus, should stand as U. $\mathrm{J}$-græcum (C. \& V.), a distinct species with no barbel on mouth.

Page 750. Acanthocottus (Grd.), scorpius (L.), var. greenlandicus (C. \& V.), Big Sculpin, or Daddy Sculpin, is occasional as far south as New York; extra-limital to New Jersey.

Page 755. ANARREICHAS Jordan puts into a family by itself.

Page 756. Add (Rhinonemus, Ayres) as synonym to Onos. .

Page 761. Add (oblongus) to synonymy of P. ocellaris.

Add P. lethostigma, J. \& G. Southern Flounder. Occasional north to New York; has a nearly plain, dusky-olive color. This properly belongs in our list.

Platophrys (Swains.), ocellatus (Ag.), (nebularis), is rarer north to Long Island; color grayish.

Page 762. Add (glacialis) to synonymy of $\mathbf{P}$. glaber.

Page 763. Add (fasciatus) to synonymy of $\mathbf{A}$. lineatus.

Page 766. Add (carolinensis) to synonymy of B. capriscus.

Page 768. Add (Orbidus) to synonymy of TETRODON (or Tetraodon.) 


\section{ERRATA.}

Page 501. For S. hudsonius, Pal., read S. hudsonicus, Erxl.

Page 505. For N. floridana, S., read N. floridana, Say \& Ord.

Page 510. For (noveboracencis), read (noveboracensis).

For L. canadensis, Sab., read L. hudsonica, L. (Mustela canadensis, Turton.)

Page 514. For B. mysticetes (cisarctica), read B. cisarctica, Cope (mysticetus, L.)

For Sibaldius, read Sibbaldius.

Page 516. For (D. Globiocephalus), read (Delphinus, Globicephalus).

Page 517. For O. gladiator, Lac., read O. gladiator, Bonnaterre (orca).

Page 526. For T. dominincensis, read T. dominicensis.

Page 527. For E. pusillus-traillii, read E. pussillus, var. traillii.

Page 541. For (Corturniculus passerinus), read (Coturniculus passerinus).

Page 553. For $\nabla$. noveboracencis, read $\nabla$. noveboracensis.

Page 557. For D. malculosa, read D. maculosa.

Page 558. For D. coerulea, read D. cærulea.

Page 571. For T. aonalaschkæ pallassii, read T. aonalaschkæ, var. pallasi.

Page 584. For O. livia, read C. livia, Briss., Sub-species domestica

Page 585. For TYMPANUOBOS, read TYMPANUOHUS.

Page 586. For G. bankiva, read G. bankiva, Sub-species domestica. Bankiva Jungle Fowl. Domestic Fowl.

Page 602. For P. jamaicencis, read P. jamaicensis. For P. noveboracencis, read P. noveboracensis.

Page 604. For Family IBID Ȧ, read Family IBIDID 2 . 
Page 622. For P. erythrorhynchus, read P. erythrorhynchos.

Page 624. For 平, hastata, read 再. hæsitata.

Page 628. For GELOCHELIDON, Brehn., read GELOCEELIDON. Brehm.

Page 632. For C. holbœlii, read O. holbœlli.

Page 641. For A. mutica, Less., read A. mutica, Le S.

For 8. undulatus, Harl. (tropidolepis), read S. undulatus, Daudin (tropidolepis).

Page 650. For R. silvatica, read R. sylvatica.

Page 652. For O. triseriatus, Cope, read C. triseriatus, Wied.

Page 653. For D. miniatus, Raft., read D. miniatus, Raf.

Page 659. For SQUALUS, L., read SQUALUS, Artedi.

Page 664. For RAIA, L., read RAIA, Artedi.

Page 667. For M. birostris, Walf, read M. birostris, Walb.

Page 668. For A. brevirostris, read A. brevirostrum.

Page 676. For H. argyrites, read H. argyritis.

Page 679. For $\mathbf{S}$. corporalis, Mitch., read $\mathbf{S}$ corporalis, Auct.

Page 684. For OLUPEA, L., read OLUPEA, Artedi.

Page 686. For Flat-back, read Fat-back.

Page 689. For SYNODUS, B.\& S., read SYNODUS, Gronow.

Page 695. For ESOX, L., read ESOX, Artedi.

Page 706. For MUGIL, L., read MUGIL, Artedi.

Page 707. For SPEYR丑NA, Bloch, read SPHYR平NA, Artedi.

Page 708. For A. americanus, read A. tobianus, var. americanus. For ECHENEIS, L., read EOHENEIS, Artedi.

Page 710. For (niger), read (nigra).

Page 731. For PERCA, L., read PEROA, Artedi.

Page 734. For (griscus), read (griseus) in synonymy of L. caxis. For EPINEPHELIS, Bloch, read EPINEPHELUS, Auct. (Cerna, Bonep.) 


\section{STATISTICS.}

\begin{tabular}{|c|c|c|c|c|c|c|}
\hline $\begin{array}{l}\text { LEADING GROUPS OF } \\
\text { VERTEBRATES. }\end{array}$ & 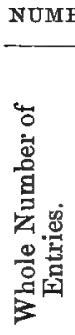 & 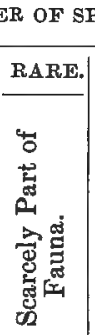 & 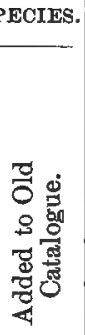 & 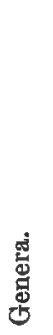 & 兽 & 起 \\
\hline 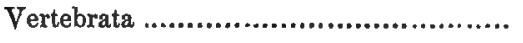 & 785 & 214 & 160 & 466 & 162 & 44 \\
\hline Mammalia..................................... & 65 & 23 & 20 & 41 & 17 & 7 \\
\hline 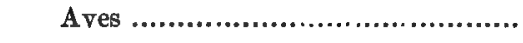 & 360 & 93 & 53 & 196 & 57 & 14 \\
\hline Order Passeres.......................... & 152 & 36 & 26 & 76 & 17 & 1 \\
\hline Family Fringillidæ ........... & 39 & 14 & 11 & 24 & 1 & ..... \\
\hline Family Mniotiltidæ ............ & 39 & 9 & 5 & 10 & 1 & $\ldots$. \\
\hline Genus Dendroica .......... & 17 & $\cdots \cdots$ & $\cdots \cdots$ & 1 & ....... & $\cdots \cdot$ \\
\hline Reptilia ............................................ & 39 & 7 & 6 & 28 & 8 & 3 \\
\hline 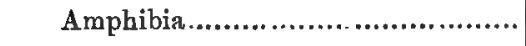 & 33 & 3 & 6 & 15 & 10 & 2 \\
\hline 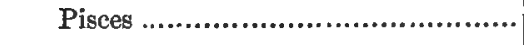 & 289 & 87 & 75 & 196 & 80 & 19 \\
\hline Marsipobranchii.................... & 4 & 1 & 1 & 3 & 2 & 2 \\
\hline Elasmobranchii . .................... & 24 & 10 & 7 & 17 & 12 & 2 \\
\hline Ganoidei................ & 4 & 1 & ....... & 2 & 2 & 2 \\
\hline Teleostei............$\ldots \ldots \ldots \ldots \ldots$ & 247 & 75 & 57 & 168 & 63 & 12 \\
\hline Order Acanthopteri........... & 131 & 46 & 23 & 91 & 36 & 1 \\
\hline
\end{tabular}

In this table the fifteen additions made in the Addenda are included. Of the additions made in the Addenda, the fishes receive the bulk; the mammals and reptiles nearly all the others. Nearly all the additions to the old catalogue go to swell the number of rare, extra-limital, occasional, doubtful or extinct species. In the column headed "rare" are not included any species that are ordinarily known as rare to collectors, provided the claim of such a species to a place in the fauna of the State is well established. The table shows at a glance that only about six hundred species of Vertebrates properly belong to our fauna, and probably less than five hundred of these are abundant or common. 



\section{ABBREVIATIONS.}

\section{(List of Authors.)}

The figures show approximately the relative (not absolute) frequeney with which the abbreviations occur (synonyms not counted).

A.

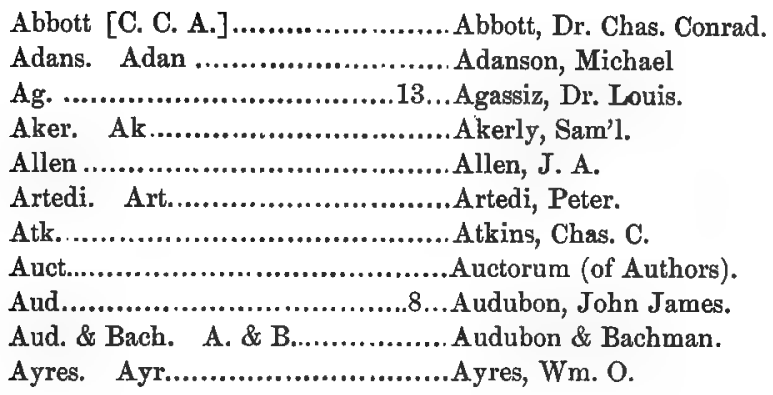

B.

Baird. Bd.....................23...Baird, Spencer Fullerton.

Bd. \& Grd. B. \& G..............10...Baird \& Girard.

Bach... .................................Bachman, John.

Bartr................................ Bartram, Wm.

Banc...................................Bancroft, Edward.

Beauvois. Beauv..................5...Beauvois, Palisot de.

Bechst. Bechs.....................7...Bechstein, Johann Matth.

Bean. B........................... Bean, Tarleton H.

Bewick.................................. Bewick, Thos.

Bibr. Bib ............................Bibron, Gabriel.

Blainv ..............................Blainville, Marie Henri Ducrotay.

Bloch. Bl. B.................. 8...Bloch, Mark Elieser.

Blochm.................................Blochmann, J.

Blas. Bl...........................Blasius, Johann Heinrich

B1. \& Schn. B. \& S..............10...Bloch \& Schneider.

Bleek ...................................Bleeker, Pieter Van.

Bodd. Bod...........................Boddaert, Petrus.

Boie.................................12...Boie,

Bosc....................................Bosc, Louis Augustin Guillaume.

Bonnat. Bonn. Bon..................Bonnaterre, Pierre Jean l'Abbe. 


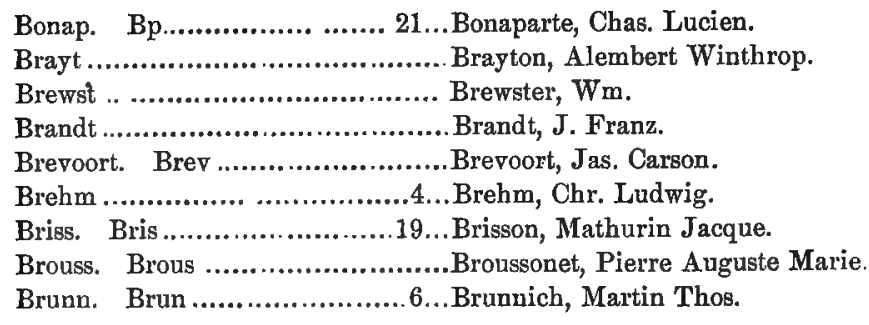

C.

Cabot................................. Cabot, Dr. S., Jr.

Cab .............................14...Cabanis, Jean Louis.

Cass. Cas.. ............................. Cassin, John.

Canestr................................ Carestrini, G. J.

Clinton................................ Clinton, De Witt.

Cooper ....................................Cooper, J. G. and Wm.

Copl ..................................Copeland, Herbert Edson.

Cope ... ..........................15...Cope, Edw. Drinker.

Collett ................................Collett, Rob't.

Coues ........................... 5.. Coues, Dr. Elliott.

Cocco . ................................ Cocco, Grasso Lorenzo.

Cuv. .............................38...Cuvier, Geo. Chrótien Leopold Dagobert.

Cuv. \& Val. C. \& V.............21...Cuvier \& Valenciennes.

Cope \& Jord. C. \& J.................. Cope \& Jordan.

Costa ................................ Costa, Achille and O. G.

D.

Dald .................................... Daldorf, -

Daud ... ............................Daudin, Francois Marie.

De K. or Dek....................12... De Kay, James Ellsworth.

Desm . ............................. Desmarest, Gaetan Anselm.

Delar............................... Delaroche, -

Donow ................................ Donovan, Edward.

Dress . ............................. Dresser, Henry E.

Dumer. Dum.......................Duméril, André Mariè Constant and Aug.

Dum. \& Bibr. D. \& B. ......... 3...Duméril \& Bibron.

E.

Erxl...................................Erxleben, Johann Christ. Polycarp.

Eyt ................................... Eyton, T. C.

F.

Faber. Fab..........................Faber, Johann.

Fabr.............................. 2... $\left\{\begin{array}{c}\text { Fabricius, Geo. Christ. and Otho (Northern } \\ \text { Fishes). }\end{array}\right.$

Finsch Finsch, Otto. 
Fitzing. Fitz..

Fitzinger, Leopold Joseph Franz.

Flem.

3...Fleming John.

Forst.

7...Forster, Johann Reinhold.

Freminv. Frem .Freminville, Christ. Paul de.

G.

Garm Garman, Samuel W.

Gapp. Gap

2..Gapper, E. P.

Gerv

2...Gervais, Paul.

Geof. Geoffroy St. Hilaire, Etienne and Isidore.

Gill. Gill, Theodore Nicholas.

Gilliams.

..Gilliams, Jacob.

Gilb Gilbert, Chas. Henry.

Gibbes Gibbes, Lewis $\mathbf{R}$.

Grd

12...Girard, Chas.

Glog... .Gloger, Constantin.

Gmel. Gm

59...Gmelin, Johann Friedrich.

Goode..

2...Goode, Geo. Brown.

G. \& B

Goode \& Bean.

Gosse.

Gosse, Philip Henry.

Gotts.

Gottsche, Karl M.

Gould.

Gould, John.

Gray. Gr.

3...Gray, Geo. Rob't (Birds.)

Gray. Gr.

12. .Gray, John Edward (Mam. \& Rept.)

Grav. Gravenhorst, Johann Edw. Christ.

Gronov. (Gronow.) Gronovius, L. Theodor and John Fred.

Green 9...Green, Jacob.

Gunn. Gun

3...Gunner, Johan Ernest.

Günth. Gthr.

2...Günther, Albert.

Guld. Guldenstädt, Johann Anton.

H.

Hald. Haldeman, Sam'l Stehman.

Harl. Har.

3...Harlan, Richard.

Hartl Hartlaub, Gustav.

Haüy Haüy, René Just, Abbé.

Hallow Hallowell, Edward.

Hass. Haslq.......................2... Hasselquist, Friedrich.

Herm ............................... Hermann, Jean F'.

Heckel. Heck,..........................Heckel, Johann Jacob.

Hensh. Hen ............................Henshall, Jas. A.

Henle .................................Henle, J.

Holbr ..............................10...Holbrook, John Edwards.

Holb. Holböll, C.

Horne ...................................Hornemann, Jens, Wilkin.

Hoy . Hoy, Philo R.

I.

Illig. Ill..........................4...Illiger, Johann Carl Wilhelm 
J.

Jord. Jor................................Jordan, David Starr.

J. \& G...................................Jordan \& Gilbert.

J. \& M...................................Jordan \& Meek.

K.

Kalm ....................................Kalm, Pehr.

Kaup ..................................Kaup, Johann Jakob.

Keyser. Keys. K....................Keyserling, Alex. B.

Keyser. \& Bl. K. \& B,................ Keyserling \& Blasius.

Kirtl, Kirt............................Kirtland, Jared Potter.

Koch.................................. Koch, Carl Ludwig.

Kram. ............................... Kramer, Wm. Henry.

Kröy..................................... Kroyer,

Kuml ..................................Kumlien, Ludwig.

Kuhl..............................4...Kuhl, Heinrich.

L.

Lat ....................................Latrobe, Benj. Henry.

Lac................................42...Lacepède, Bernard Germain.

Lafres. Laf...........................Lafresnaye, Etienne.

Lath..............................5...Latham, John.

Latr.....................................Latreille, Pierre Andre.

Lawr...................................Lawrence, Geo. N.

Laur................................2...Laurentini, Joseph Nicolas.

Le C..............................10...Le Conte, John L.

Le S................................21...Le Sueur, Chas. Alex.

Less. Les............................7...Lesson, René Primevère.

Lepech................................Lepechin, Iwanowitch.

Leach.............................10... Leach, William Elford.

Link ..................................Link, J. H.

Licht............................. 4...Lichtenstein, Anton August Heinrich.

Linn. Lin. L.............. 292...Linnæus, Carl von.

Lowe.................................Lowe, R. T.

Lütk. Lüt..........................Lütken, Chr. F.

M.

Mayn....................................Maynard, C. J.

Merr. Mer...........................Merrem, Blasius.

Mitch.............................41....Mitchill, Sam'l Latham.

Meek..................................Meek, Seth E.

Montag. Mont.....................2...Montagu, George.

Müll. Mül.......................6...Müller, Otto Friedrich and Johannis.

M. \& H................... *.........4...Müller \& Henle. 
N.

Naum.................................Naumann, Carl Friedrich and Joh. Andreas.

Nels

Nils. Nelson, Edw. W.

Nutt Nilsson, Sren. ..Nuttall, Thos.

O.

Ord 7...Ord, Geo.

Osb... 2...Osbeck, Pehr.

P.

Pall. Pal

6...Pallas, Peter Simon.

Peck .Peck, Wm. Dandridge.

Pom . Pomel, A.

Putn.

2...Putnam, Fred. Ward.

Poey... .Poey, Felipe.

R.

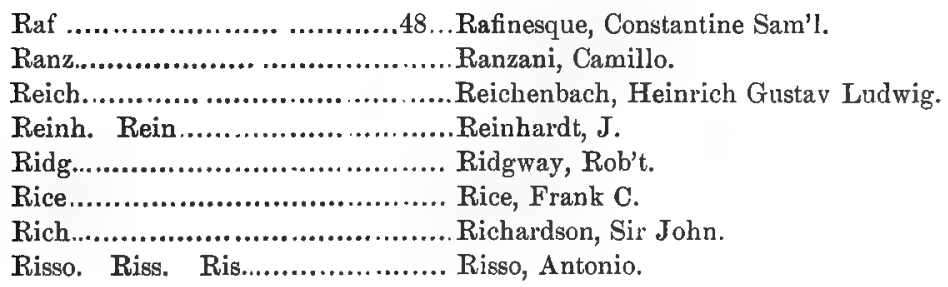

S.

Sab.

2...Sabine, Edw.

Savig. Sav

3...Saviguy, Marie Jules Cesar Lelorgne de.

Say. 13...Say, Thos.

Schl ..Schlegel, Hermann.

Schr. Schreber, Johann Christopher Daniel von.

Schn. Schneider, Johann Gottlob.

Schranck

2...Schranck, Franz von Paula.

Schw 3...Schweigger, August Friedrich.

Scop Scopoli, John Anton.

Schöpff. .Schöpff, Johann David.

Sclat. Scl. Sclater, Phil. Lutley.

Smith, H Smith, Hamilton L.

Sharpe Sharpe, Richard Bowdler.

"Shaw

5...Shaw, Geo.

Sharpl Sharpless, J. T.

Sprague. Sprague, Isaac.

Stor.

8...Storer, Horace Rob't and David Humphrey. 


\section{GEOLOGICAL SURVEY OF NEW JERSEY.}

Strickl. Strick.........................Strickland, Hugh.

Steph ................................6...Stephens, Jas. Francis.

Stejn ....................................Stejneger, Leonhard.

Steind ............................... Steindachner, Franz.

Suckl...................................... Suckley, Geo.

Sund....................................Sundevall, Charles James.

Sw. \& Rich. S. \& R...............2...Swain \& Richardson.

Swains. Sw......................23...Swainson, Wm.

Swain ............................. Swain, J.

T.

Temm ............................ 2...Temminck, Conrad Jacob.

Towns .................................Townsend, J. K.

Thomps. Thom.......................Thompson, Rev. Zadock.

Tschud. Tsch......................... Tschudi, Johann Jakob.

Traill .................................... Traill, Thos. Stewart.

Thunb. Thun.. .......................Thunberg, Carl Peter.

Turt ............................... Turton, Wm.

Tunst.................................. Tunstall, Marmaduke.

$\mathrm{V}$.

Val.................................... Valenciennes, Achille.

Vaillant. Vaill........................Vaillant, Francois Le.

Vieill.................................Vieillot, L. P.

Vig................................... Vigors, Nicholas Aylward.

Vand.....................................Vandelli, Domenico.

W.

Walb...............................12...Walbaum, Johann Jul.

Wagl...............................4...Wagler, John.

Wils..............................24...Wilson, Alex

Wath. Wat.......................... Waterhouse, Geo. Rob't.

Wied.....................................Wied, Max. Alex. Phil.

Wieg....................................Wiegmann, Arend Friedrich Aug.

Weinl. Wein........................... Weinland.

Z.

Zimmer. Zim ....................... Zimmermann, Eberhard Aug, Wilh. 


\section{GENERAL ABBREVIATIONS.}

The numerical measurements given with each specific description are only averages, and considerable variations are likely to be found. In the fishes the Roman numerals indicate stiff rays, and the Arabic soft rays in tins. When the figures are separated by a dash or plus, the fin is composed of corresponding distinct parts. Posterior finlets are also represented by a Roman numeral indicating their number. The number of scales along the lateral line (or in its absence, along an imaginary line) are indicated, and when the scales are unlike on different parts of body, the number is broken by dashes or otherwise. 



\section{INDEX.}

This Index refers to the Catalogue as emended according to the

Addenda and Errata.

A.

Abbott, Dr. Charles.

Abramis.

Ablabes,

Acadian Flycatcher...................... 528

acadianus, Hemitripterus............... 748

acadica, Nyctala......................... 580

acadicus, Empidonax...................... 528

Acantharchus ............................ 725

Acanthias .................................... 659

acanthias, Squalus....................... 659

Acanthis ................................. 538

Acanthocottus........................... 749

Acanthosoma ............................ 769

Acanthopteri............................ 705

Acanthuridæ ........................... 745

Accipiter................................. 574

accipitrinus, Asio....................... 580

achigan, Bodianus..................... 728

Achirus ........................................ 763

achirus, Solea............................ 783

Acipenser ................................ 668

Acipenseridm............................... 668

Acris ..................................... 651

Acronurus................................ 745

Actidromas bonapartei (referred to).. 599

Actitis ................................... 596

Actiturus bartramius.................... 596

acuflavidus, var. of Sterna sandvi-

censis

aculeatns, Chrysophrys................. 736

acuta, Dafila

Gasterosteus ..................... 705

Mpliobatis......................... 666

acutiroerca ............................. 731

acutus, Lagenorhynchus.................. 516

Adder ..............................643, 647

adspersus, Ctenolabrus.................... 743

aëdon, Troglody tes (referred to, 567).. 566

Ægialitis

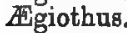

巴Eglifinus

æneus, Centrarchus

Cottus

Cottus.........................750 750 æstiva, Dendroica..................... 556

Píranga........................... 548

æstivalis, Clupea.......................... 685

æstivus, Phyllophylophis................ 646

झૈstrelata ................................... 624

\#ttobatidæ..................................... 666

affinis, Aythya............................ 615

Esox................................. 696

Agelaius ................................. 532

agilis, Geothlypis...................... 561

Agnus ................................... 746

Agonidr ..................................... 750

agrestis, Spizella......................... 543

Ailurichthys................................ 673

ailurus, Pimelodus........................ 672

Aix .......................................... 614

Alaudidæ ................................... 528

alba, Guara,..................................... 604

Albacora...................................... 714

albeola, Charionetta...................... 616

albicauda, Echeneis...................708, 709

albicollis, Zonotrichia..................., 543

Albicore................................. 714

albidus, Ameiurus............................. 672

Gadus ............................ 759

Ictalurus.......................6.672

Tetrapturus ..................... 711

albifrons, var. gambeli, Anser.......... 619

Albula... ................................... 682

albula, Mugil............................. 706

Albulidm ..................................... 682

Alea ............................................... 635

Alcedinidm................................... 522

Alcidæ........................................... 634

alcyon, Ceryle............................. 522

alepidotus, Gobius...................... 747

Alewife ..................................... 684

Alle ....................................... 636

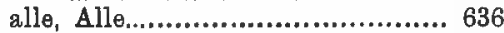

alleghaniensis, Coluber................... 645

Alligator-fishes ............................ 750

Allmonth .................................. 763

Alopiidæ ................................ 661

alpestris, Otocoris....................... 528

alpina, var. pacifica, Tringa............ 592

Alopecias................................. 662

Alopias .................................. 662

(789) 
Alosa

684,685

Alvarius ...................................... 729

Alutera..................................... 767

ambassis, Sargus......................... 737

Amber-fish ................................. 718

Ambloplites ........................724, 725

amblyrhynchus, Caranx................. 715

Amblystoma .............................. 655

Amblystomatidø ........................ 655

Amblystomidæ.......................... 655

Ameiurus... ................................ 671

americana, Anas......................... 612

Aythya ...................6 614 vor. of Certhia familiaris, 568

Compsothlypis ............. 556

Curvirostra................... 537

Fulica....................... 604 var, of Glaucionetta clan-

gula .................... 615

Lucioperca .................. 731

Morrhua ..................... 758

Oidemia ...................... 618

Perca.......................... 731

Raia ......................... 664

Recurvirostra................ 588

Stilbe....................... 681

Spiza ........................... 547

Tautoga .................... 743

var. of Tringa alpina...... 592

American Avocet.......................... 588

Barn Owl.................... 579

Bittern ......................... 605

Black Scoter................. 618

Black Tern.................. 630

Coot........................... 604

Creeper ........................ 568

Crossbill...................... 537

Crow .......................... 530

Dunlin ...................... 592

$\mathrm{Eel}$............................6 697

Egret............................6 607

Eider Duck,................. 617

Golden- $\theta y \theta$ Duck............. 615

Golden Plover................ 597

Goldfinch...................... 538

Goshawk...................... 575

Hawk Owl................... 582

Herring Gall.................. 626

Hop-toad..................... 652

Long-eared Owl............. 579

Merganber .................... 609

Merlin ......................... 578

Osprey........................ 578

Oyster-catcher ................6 600

Perch ........................... 731

Pine Grosbeak.............. 537

Pipit ........................... 564

Red Breast.................... 572

Start....................... 564

Robin ....................... 572
American Rough-legged Hawk...... 576

Salamanders ................. 654

Scaup Dack................. 615

Smelt........................... 689

Snipe ........................... 589

Sparrow Hawk.............. 578

Sturgeon ................... 668

White-fronted Goose........ 619

White Pelican............... 622

Widgeon ...................... 612

Woodcock ....................... 589

americanus, Abramis .................... 681

Acanthias.................6, 659

Ammodytes................. 708

var. of Bufo lentiginosus, 652

Coccyzus................... 522

Corvus ...................... 530

Cygnus...................... 620

Enchelyopus, Phycis..... 757

Esox........................... 695

Hemitripterus ............. 748

Hippoglossus .............. 761

Lepus ....................... 507

Leucosomus ................. 681

Lophins ...................... 763

Merganser .................. 609

Odontaspis .................. 662

Petromyzon ............... 658

Pleuronectes .................. 762

Roccus ..................... 732

Scapanus ................... 498

Squalus..................... 662

var. of Troglody tes aëdon 566

Tympanuchos ............. 585

Ursus ....................... 512

Amiurus ......................................... 671

Ammocostes ............................... 658

Ammodramus .......................... 541

Ammodytes.................................. 708

Ammodytidæ ............................... 708

amconus, Carphophiops.................... 647

Ampolidæ .................................... 550

Ampelis .................................... 550

Amphibia .............................492, 649

Amyda..................................... 641

Anacanthini................................ 705

analis, Orthagoriscus,...................... 770

analostana, Cliola......................... 677

Anarrhichas.............................. 755

Anss...................................... 610

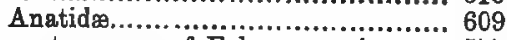

anatum, var. of Falco peregrinus..... 577

Anchovies................................. 688

Ancistrodon.................................. 648

Ancylocheilus subarquata.. ............ 592

Ancylopsetta............................ 761

andersonii, Hyla.......................... 651

Anderson's Tree-toad..................... 651

Angel-fishes.............................. 744

Angel-fish ............................744, 745 
Angler..................................... 763

anglica, Gelochelidon................... 628

anglorum, Lumpus........................ 753

Puffinus.......................... 623

Anguilla............................697, 698 var. rostrata, Anguilla...... 697

anguillaris, Zoarces....................... 755

Anguillidm ............................. 697

angusticeps, Blarina.................... 497

Anisotremus............................. 735

annulata, Melanura..................... 695

Anoplagonus........................... 750

Anoura................................... 649

anoplus, Astroscopus..................... 746

Anser ..................................... 619

Anseres........................................609

Antennarius............................. 764

Antennariidæ.......................... 764

Anthus................................. 564

antiquorum, Hippocampus............. 702

antillarum, Sterna...................... 630

Antrostomus ............................ 523

Anura ...................................... 649

aonalaschkm, var. pallassii, Turdus... 571

Apeltes..................................... 705

appendix, Ammoccotes.................... 658

Pomotis...................726, 727

Aphredoderidæ .......................... 722

Aphredoderus ................................ 723

Aph.rizidæ................................ 600

Aplesion ...................................... 729

Apodes..................................... 697

Apomotis ................................ 726

aquaticus, Scalops.......................... 498

Aquila.................................... 577

aquosus, Rhombus....................... 760

aranea, Sterna........................... 628

Archibuteo .............................. 576

Archosargus............................. 738

arctica, Fratercula........................ 634

Arctic Jaeger.............................. 625

Puffin ............................ 634

Tern ............................. 629

arcticus, Urinator,.......................... 633

arctifrons, Citharichthys................ 760

Arctodromas .............................. 591

Arctomys..................................... 602

arcuatum, Hæmulon...................... 735

Arden ..................................... 606

Ardetta ...................................... 606

Arenaria.................................... 600

arenaria, Callidris ......................... 593

arenosus, Stenotomus................... 737

Ardeidø ................................... 605

argentatus, Plargyrus ................... 678 var. smithsonianus, Larus 626

argentea, Selene....................716, 717

Argentinidæ ............................... 689

argenteus, Eucinostomus ................ 742

Leuciscus..................... 680 argenteus, Trichiurus.................. 711

Argyrea .................................. 707

Argyreus.................................. 678

Argyriosus .........................716, 717

argyrites, Hybognathus................, 676

argyrolencus, Corvina, Bodianus..... 739

argyrophanus, Stolephorus............ 688

argyrope, Sparus, Pagrus, Stenoto-

mus........................ 737

Stenotomus..................... 736

Ariopsis ........................................ 673

Aristonetta.............................. 614

Arius ........................................ 673

Arkansas Flycatcher....................... 526

Eingbird..................... 526

Aromochelys ............................. 640

Arquatella................................. 591

Arvicola.................................. 505

Asio.................................... 579

asio, Megascops............................ 581

Aspidonectes ............................... 640

Aspidophoroides .......................... 750

Astatichthys............................. 729

Asternotrema ............................ 723

Astroscopus .................................. 746

Atalapha ................................ 494

ater, Molothrus,........................... 531

Atherina................................. 689

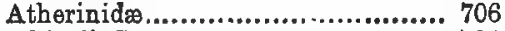

atkinsii, Gasterosteus.................... 704

Atlantic Salmon......................... 690

atlanticus, Elacate....................... 710

Megalops................... 683

atrarius, Pimelodus....................... 671

Serranus,....................... 733

atrata, Catharista,...................... 574

atricapillus, Accipiter..................... 575

Parus........................ 569

atricilla Larus......................... 627

atromaculatum, var. of Boleosoma

olmstedi........... 728

Cyprinus.............. 679

atronasus, Rhinichthys................ 679

auctorum, Lobotes........................ 736

auduboni, Dendroica.................... 557

Puffinus. ....................... 624

Audubon's Shearwater................. 624

Warbler.................... 557

Auks ...................................... 634

aura, Cathartes............................. 573

aurantiacus, Balistes........................ 767

Ceratacanthus .............. 767

auratus, Carassius........................ 682

Colaptes ......................... 521

Gadus ........................... 758

aurea, Clapea.............................. 686

aurocapillus, Seiurus...................... 560

aurolineatus, Dirbasis....................... 736

auriga, Dules............................. 734

auritus, Colymbus (referred to, 632)... 631 
auritus, Lepomis.......................... 726

autumnalis, Plegadis.................... 605

Autumn Warbler........................ 558

Auxis................................ 712

Aves.................................... 518

A vocets ................................. 588

Apthya.................................. 614

B.

Bairdiella 739

Baird's Sandpiper........................... 592

bairdii, Tringa.......................... 592

Balæna.................................... 514

Balænidæ ..................................... 514

Bald Eagle............................. 577

Baldpate................................. 612

Balistes ............................766, 767

Balıstidæ................................. 766

Balloon-fish.............................. 768

baltimore, Icterus....................... 534

Baltimore Oriole......................... 534

Banded Darter........................... 729

Drum .............................. 739

Leriole.......................... 719

Pickerel......................... 695

Rattlosnake ....................6.648

Barnacle Goose.......................... 620

Barn Owle............................... 579

Swallow............................ 549

bankiva, var. domestica, Gallus....... 586

Bank Swallow.......................... 550

Barb .......................................... 741

Barred Owl................................ 580

Barfish..................................... 724

Barndoor Skate....... .................... 665

Barracudas .............................. 707

Bartramia ............................... 596

Bartramian Sandpiper..................... 596

Bascanium ................................ 645

Basking Sharks.......................... 663

Bass...........................727, 732, 740

brssana, Sula ............................ 621

Batfishes ................................. 764

Batfish...................................... 765

Batoidei...................................... 663

Batrachia................................. 649

Batrachians............................. 649

Batrachidg...................................... 753

Batrachus ................................. 753

Bats .................................... 494

Bay Porpoise.................................. 516

Bayou Bass.............................. 727

Bay.breasted Warbler................... 558

Bay-winged Bunting.................... 542

Beare.. .................................... 512

Beaver ................................... 503

Bee Martin................................... 526

Belted Kingfisher........................ 522
Bellows-fish ............................ 763

Bergall....................................... 743

bernicla, Branta........................ 620

bewickii, Thryothorus .................. 566

Bewick's Wren........................... 566

biaculeatus, Gasterosteus.............704, 705

bicolor, Amblystoma ................... 656

Calamospiza .................... 547

Pards ........................... 569

Tachycineta ..................... 449

bifrenata, Hemitremia ................. 677

Big Drum................................ 739

Big-eyed Herrings......................... 683

Scad ........................... 715

Big Salamanders......................... 655

Sapsucker ........................... 518

Scaup Dack............................ 615

Skate Ray........................... 664

biguttatus, Ceratichthys ................ 679

bilinearis, Merlucius ..................... 759

bilineatns, Spelerpes ..................... 654

Billfish .........................669, 700, 711

Birds....................................... 518

birostris, Manta......................... 667

Raia.............................6 667

bispinosus, Myliobatis .................. 666

bisus, Aurig ............................. 712

Bitterns................................... 605

Black and White Creeper................. 554

Warbler .............. 554

Yellow Warbler.............. 557

Black-banded Sunfish.................... 726

Black Bear......... ...................... 512

Black-bellied Plover...................... 598

Sandpiper .................. 592

Black.billed Cuckoo...................... 522

Blackbird ..............................532-536

Black Brant............................... 620

blackburniæ, Dendroica .................. 559

Blackburnian Warbler.................. 559

Black-capped Chickade日.................. 569

Petrel ..................... 624

Black-cap Titmouse........................ 569

Black Cat .................................... 509

Catfish ............................. 671

Dolphin .............................. 515

Duck.................................. 611

Black -eared Sunfish......................... 720

Blackfish (mammal). .................. 517

(fiehes).....................732, 743

Black Fox................................ 508

Grouper............................. 733

Grunt................................. 735

Guillomot.............................. 634

Black-headed Gull......................... 627

Black Hawk............................... 576

Logcock ............................ 520

Black-masked Ground Warbler....... 562

Black-necked Stilt....................... 588

Black-nosed Dace......................... 679 
Black-poll Warbler........................ 558

Black Rat ................................. 504

Skimmer ............................. 631

Snake................................. 645

Squirrel .............................. 501

Black-tailed Godwit.................... 594

Black-throated Blue Warbler......... 557

Bunting................. 547
Diver ............... 633
Green Warbler....... 559
Loon..................... 633

Black Sucker .............................. 674

Triple-tail............................... 736

Vulture................................. 574

Whale ............................514, 517

Woodcock.............................. 520

Blarina..................................496, 497

Blennies..................................... 753

Blennius..................754, 755, 756, 757

Blenniidø................................... 753

Blepharis ...................................... 716

Blob ...................................... 749

Blower ..................................... 768

Blowing Viper.............................. 643

Blue-back Herring......................... 685

Blue-bill Duck............................ 615

Bluebird .................................... 573

Blue Catfish................................ 672

Darter ................................ 729

Bluefishes .............................. 720

Blue Golden.winged Warbler......... 554

Blue-gray Flycatcher...............528, 570

Blue Groseak

Blue-headed Flycatcher................... 553 Vireo .......................... 553

Blue Jay (referred to, 540)............. 529

Perch ................................. 743

Pike .................................. 731

Blue-spotted Salamander............... 654

Blue Stocking ............................. 588

Blue-tailed Lizard........................ 642

Blue Warbler ............................... 558

Blue-winged Teal......................... 611

Yellow Warbler......... 555

Blue Yellow.backed Warbler.......... 556

Blunt-nosed Bat............................. 496

Minnow................... 676

Shiner... ................ 717

Bobolink................................... 531

Bob White.............................. 584

Bodianus ...................724, 728, 731, 739

Bog trotter ............................ 574

Bohemian Wax-wing................... 550

Boleichthys .............................. 729

Boleosoma .............................728, 730

Bombycillidæ............................. 550

Bonaparte's Gull.......................... 627

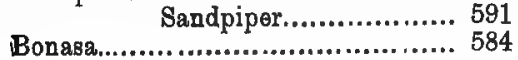

bonasus, Rhinoptera .....................666 666

Bone Dog ..................................... 659

Bonefish........................................ 682

Bonito ......................................... 713

Bonnet-head Shark....................... 661

Bony-fish.................................. 686

Bony Gar................................. 669

borealis, Buteo ............................ 575

Contopus ....................... 527

Dryobates .................... 519

Lanius (referred to, 540)... 551

Numenius ........................ 597

Puffinus............................ 623

Rorqualus (referred to)...... 514

Sphyræna ....................... 707

Borer........................................657 657

boreus, Esox............................... 696

boschas, Anas................................. 610

bosci, Gabiosoma........................... 747

bosqui, Cyphosus............................. 738

bosquianus, Chasmodes....................... 754

bostoniensis, Catostomus.................. 674

Murma ..................... 697

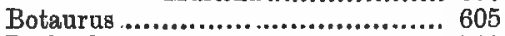

Bothrolæmus ................................. 718

Bothus ....................................... 760

Bottle-nosed Dolphin...................... 515

bovinus, Cyprinodon........................ 692

Bow head Whale........................... 514

Box Tortoise..................................... 637

Turtle................................ 637

brachycium, Phocæna................... 516

brachyptera, Echeneis..................... 708

Remora.................... 709

brachypterus, Globicephalus............. 517

Brachyrhinus …............................. 733

Branch Herring............................ 684

branchialis, Ammocostes.................. 658

Branta ........................................ 620

Brant Goose.................................. 620

brasiliengis, Mugil......................... 706

Bream …..........................727, 737, 681

brevicauda, Blarina, ........................ 496

brevirostris, Acipenser..................... 668

Hippocampus.............. 702

Tetrapturus ................. 711

Brevoortia..................................6. 686

breweri, Scapanus............................ 498

brewsteri, Acanthis.......................... 538

Brewster's Linnet............................ 538

Warbler ...................... 555

Brier Ray .................................. 665

Broad-bill Ducks (referred to, 610) .. 615

Broad Shiners... .......................... 720

Broad-winged Hawk..................... 575

broccus, Balistes.................................. 766

Banthorinus..................... 767

Bronzed Grackle............................ 536

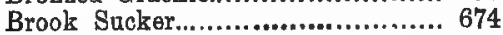

Trout................................. 691 
brosme, Brosmius........................ 757

Brosmius................................. 757

Brown-back Dowitcher................. 590

Brown Bat.................................. 495

Bear .............................. 512

Creeper ........................ 568

Brown-crowned Night Heron.......... 609

Brown Lark............................. 564

Rat (referred to, 505).......... 504

Thrasher........................ 565

Thrush ........................... 565

browni, Stolephorue...................... 688

Vomer ......................... 717

Bryttus .................................725, 726

Brünnich's Murro........................ 635

Bubo .................................... 581

Bubonidæ................................... 579

buccinator, Olor........................... 621

Bucephala ...........................615, 616

Buff-breasted Sandpiper................. 596

Bufonidx..................................... 652

Bufo ......................................... 652

Bugfish.......................................... 686

bullaris, Semotilus......................... 680

Bull Bat.............................. 523

Bull Frog................................... 650

Bull-herd ............................661, 749

Bull-headed Eel........................... 698

Ball Snake................................... 645

Bumper................................... 717

burgall, Ctenolabrus..................... 743

Burgomaster ............................... 626

Burnstiekle................................. 705

Butcher Bird............................. 551

Buteo ......................................... 575

Butorides.................................... 608

Butter-bill ............................... 618

Butter-fish ..............................721, 754

Buzzard .................................... 575

C.

Cabot's Tern............................... 629

cærulea, Ardea............................. 607

Dendroica ...................... 558

Guiraca......................... 546

Polioptila ..................... 570

Cærulean Warbler........................ 558

cærulescens, Dendroica.................... 557

Pimelodus ................ 672

cæruleas, Acanthurus (referred to)... 746

Carcharias......................6 660

Ctenolabrus..................... 743

Calamilichthys................... 729

Calcarius...................................... 547

Calemys .................................. 637

calendula, Regulus...................... 570

Calico Bass................................... 724
Calico Snake............................ 647

Calomys... ................................... 505.

callarias, Gadus........................ 758.

Callidris.................................. 593

Calliurus ................................ 728

camelinus, Tetrasomus.................. 766

Camtolaimus .............................. 617

canada, Echeneis.......................... 710

Canada Goose ........................... 620

Porcupine ...................... 507

canadensis, Branta .................... 620

Castor ..................... 503

Dendroica ................. 557

Lutra......................... 510

var. of Pinicola enuclea-

tor ....................... 537

Salmo ....................... 691

Sitta ........................ 569

Sylvania ................. 563

Canadian Flycatcher ..................... 563

Warbler ......................... 563

candissima, Ardea..................... 608

Canidæ ........................................ 508

caninus, Caranx ........................ 716

canis, Mustelus. ........................ 660

cantabrigensis, Rana.................... 650

Gantherines................................ 767

Canthorinus.........................766, 767

cantiacus, Thalasseus....................... 629

Canvas-back .............................. 614

canntus, Tringa.......................... 591

caparoch, var, of Surnia ulula ........ 582

Oapo May Goody........................ 740

Warbler........................ 556

capillaris, Argyreiosus................... 717

Zous............................ 716

Caprimulgidæ ................................. 523

capriscus, Balistes............................ 766

caprodes, Percina........................ 729

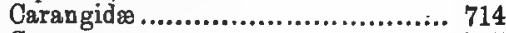

Carangus ................................. 715

carangus, Scomber................... 716

Caranx ......................714, 715, 716

Carassius................................... 682

carbo, Phalacrocorax...................... 621

carbonaria, Pileoma..................... 729

carbonarius, Pollachius..................... 758

Carcharias .................................660, 662

Carchariidø .............................. 600

Cardinal Grosbeak......................... 545

Cardinalis..................................... 545

cardinalis, Cardinalis....................... 545

Carduelis................................... 539

carduelis, Carduelis........................ 539

caretta, Thelassochelys................... 640

Cariacus ................................... 513

caribbæus, Chloroscombrus............. 717

carinatum, Acanthosoma.............. 769

Carnivora ................................... 508

carnivorus, Corvus.......................... 529 
Carolina Bat

carolina, Cistudo

Carolina Dove.

Lichia.....

Porzana

Wren

carolinensis, Anas

Balistes

Galeoscoptes.

Halatractus.

Otolithns

var. of Pandion haliaë.

tas.

Scinrpe...

Seriola ................... 501

Sitta........................ 568

Tyrannus .................. 526

Vespertilio ................4495

var. of Vespertilio fuscus......

Zenaidura

carolinus, Clinostomus.

681

Melanerpes...................... 521

Prionotus.................... 751

Scolecophagus............... 534

Trachynotus .................. 718

Carp......................................... 682

Carps ...................................... 676

carpio, Cyprinns......................... 682

Carpiodes................................. 674

Carphophiops............................ 647

Carpodacus .............................. 537

Carrion Crow.............................. 574

Caspian Tern........................... 628

caspius, Thalassens...................... 628

castanea, Dendroica...................... 558

Castor ..................................... 503

Castoridæ ............................... 503

cataractæ, Ceratichthys................. 678

$\begin{array}{lll} & \text { Rhinichthys................ } & 678 \\ \text { Catbird.................................... } 565 & 56 . \ldots\end{array}$

catesbiana, Rana............................ 650

Catfishos .................................... 671

Catfish...................................... 672

Cathartes ................................... 573

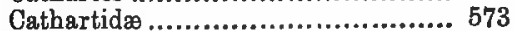

Catharista.................................. 574

Catonotas ................................. 729

Catostomidæ................................ 673

Catostomus................................. 674

Cat Owl.................................. 579

Cats ....................................... 508

catus, Amiurus............................. 671

caudacuta, Motella..................... 756

caudacutus, var. nelsoni, Ammo-

dramus .................................... 541

caudata, Lamna.............................. 660

Cave Salamander....................... 655

cavifrons, Ambloplites................... 724

caxis, Latjanus.
Cecomorphæ........................., 623

Cedar Bird ................................. 551

Wax wing ...................... 551

cedrorum, Ampelis...................... 551

celata, Helminthophila................. 555

Celuta .................................... 647

Centrarchidæ............................. 724

Centrarchus ...........................724, 725

Centronotus................................. 754

Centropristis .............................. 733

centrura, Trygon........................ 666

Centurus .................................... 521

Ceophlœus ............................... 520

cepedianum, Dorosoma................. 687

Cephalacanthus ........................... 752

Cephalopteridæ............................ 667

Cephaloptera ............................... 667

cephalus, Mugil......................... 706

Semotilus ..................... 679

Cepphus................................... 634

Ceratacanthus ........................... 767

Ceratichthys ...........................678, 679

Ceratoptera ................................. 667

Cerna ...................................... 734

Cero........................................... 713

Certhia ....................................... 568

Certhiidæ .................................... 568

Cervidæ...................................... 513

Cervus....................................... 513

Ceryle ........................................ 522

Cestracion.................................. 661

Cestreas .................................. 741

Gistudo..................................... 637

Cetacea-Carnivora........................ 514

Cetaceans.................................. 514

Cete .......................................... 515

Cetorhinidoe............................... 663

Cetorhinus ................................... 663

Chænopsetta................................... 761

Chætodipterus .............................. 744

Chætodon..........................744, 745

chætodon, Mesogonistius............... 726

Chætodontidæ.............................. 744

Chætura ................................. 524

Chain Snake ................................ 647

chalybæus, Hybopsis..................... 678

Channel Bassnilus .................... 678

Catfish........................... 672

Charionetta............................... 616

Charadrius ................................... 597

Charadriidæ................................... 597

Charioteer................................... 734

Chasmodes................................ 754

Chatoëssus ............................... 687

Chaulelasmus............................... 612

Cheiroptera,................................ 494

Chelidon ..................................... 549

Chelopus ...................................... 637

Chelydra .................................. 640 
Chelydridø.............................. 640

Chelonia............................................ 637

Chelonidæ................................. 640

Chelopus..................................... 638

Chen.......................................... 619

Cherry Bird............................... 551

Chestnut-sided Warbler.................. 558

Chewink ................................... 545

Chickadee ............................... 501

Chickaree..................................... 801

Chicken Hawk.......................... 575

Chilomycterus........................... 769

Chilonemus ................................. 679

Chimney Swallow....................... 524

Swift ....................... 524

Chipping Sparrow ....................... 543

Chippy ...............................542, 543

Chipmunk (referred to, 510)........... 502

chirurgus, Acanthurns (referred to)... 746

Chironectes ................................ 764

Clinostomus.............................. 681

Chloris ........................................ 556

chloris, Seriola........................... 717

Chloroseombrus ....................... 717

Chogget..................................... 743

Chondestes............................... 542

Chondrostei ............................... 668

Chordeiles................................. 523

Chorophilus................................ 652

chouicha, Oncorhynchus............... 690

Chroscócephalus ......................... 627

chromis, Pogonias...................... 739

Ohrosomus ............................... 676

chrysaëtos, Aquila........................... 577

Chrysemys .............................. 638

chrysocephalus, Luxilus................ 678

chrysoleucus, Notemigonus............ 681

Chrysomitrig ............................ 538

Chrysophrys............................. 736

chrysoptera, Helminthophila.......... 554

chrysops, Stenotomus, Sparus.......... 736

chrysopterum, Hæmulon. ............. 736

chrysos, Carangus....................... 716

chrysura, Sciæna......................... 739

chrysurus Chloroscombrus........... 717

chrysus, Caranz........................... 715

Chub ...............................679, 680

Chubby Catfish.......................... 672

Chub Mackerel.......................... 712

Sucker.............................. 675

chuss, Phycis........................... 757

Cichla........................................ 727

Ciconiidæ ...................................... +05

Cigar-fish ................................. 714

ciliaris, Pomacanthus..................... 745

ciliatus, Blennius........................... 755

cimbrius, Onos............................ 756

cinerea, Atalapha...................... 495

Blarina ............................ 497

cinereo argentatus, Urocyon............ 509 cinereum, Scotiapex................... 580

cinereus, Atalapha..................... 495 var. erythronotus, Pletho-

don ....................... 654 var. of Plethodon cinereus. 654 var. of Sciurus niger......... 500

cingulatus, Zygonectes................... 694

Cinnamon Bear.......................... 512

Cinosternidæ ............................... 639

Cinosternum............................. 639

Circus.......................................... 574

cisarctica, Baløna....................... 514

Cistothorus ................................... 567

Githarichthys ................................ 760

Claips ...................................... 521

clamata, Rana......................... 649

Clam-cracker ................................ 666

Clangula .............................615, 616

clangula, var. americana, Glaucio-

netta,................................... 615

Clapper Rail.............................. 601

Classification................................ 492

Cliff Swallow............................... 549

Climbing Birds........................... 518

Cliola ....................................... 677

Clivicola ......................................... 550

Cluper ........................677, 684, 686

Clupea harengus (referred to) ......... 578

Clupeidø...............................683, 687

clymen $\theta$, Delphinus..................... 515

clypeata, Spatula.........................6.613

Coachman .................................. 734

Coalfish .................................. 758

Cobia ..................................... 710

Cobitis ..................................... 693

Coccyges ................................... 522

Coccyzus ................................... 522

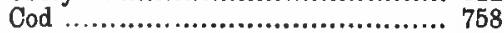

Codfishes .................................. 756

Codling .................................. 757

Coffin.carrier Gall......................... 626

Colaptes ................................. 521

colchicus, Phasianus (referred to).... 586

colias, Scomber.........................., 712

Colinus ................................... 584

collaris, Aythya .......................... 615

Collecting Specimens..................... 492

Colocephali.................................. 697

Coluber ..................................... 645

Colubridæ.................................. 643

colubris, 'Trochilus ........................ 524

Columba ................................... 584

Columbø ..................................... 583

columbariug, Falco..................... 578

columbianus, Olor...................... 620

Columbidx ................................. 583

Colymbus..................................... 631

Colymbus torquatre..................... 633

cornatus, Oypselurus ....................... 701

commersoni, Catostomus ............... 674 
Common American Eel................ 697

Atlantic Salmon................6 690

Bats ............................. 494

Box Turtle................... 637

Catfish......................... 672

Channel Cat.....................6 672

Chub.............................. 679

Codfish ............................ 758

Cormorant ........................ 621

Eastern Pickerel............... 696

Frog .............................649 649

Gar Pike..................... 669

Garter Snake................. 644

Gull........................... 626

Herring ....................... 684

Killifish.......................... 698

Mackerel ......................... 712

Mole............................ 498

Pheasant (referred to)....... 586

Pipefish ...................... 702

Pompano...................... 718

Porpoise...................... 516

Rock Bass...................... 724

Sea Horse....................... 703

Shad............................ 685

Shiner .......................... 678

Skate.. ........................ 664

Snapping Turtle............. 640

Soft-shelled Turtle............ 640

Stickleback .................... 705

Sting Ray.................... 666

Sucker........................... 674

Summer Flounder.............. 761

Sunfish........................ 727

Tern ............................ 629

Tree-tord.......................... 650

Winter Flounder............. 762

communis, Catostomus................ 674

Phocæna .................... 516

Compsothlypis................................ 556

Condylura ................................. 498

Conger ...................................... 698

Conger Eelpont.......................... 755

conger, Leptocephalns .................. 698

Connecticut Warbler..................... 561

Conner ...................................... 743

conorhynchus, Albula ................. 682

conepersum, Amblystoma ............. 656

constrictor, Bascanium ................. 645

Contopus.................................... 527

contortrix, Ancistroden ............... 648

cookianus, Aphredoderus............. 723

Coons ........................................ 512

Cooperi, Accipiter...................... 575

Sorex............................... 497

Cooper's Hawk............................ 575

Coot........................................... 604

Coots ...................................... 618

Copelandia.................................. 725

Copperhead Snake....................... 648 corax, var. principalis, Corvus....... 529

coriacen, Dermochelys................... 640

Cormorants................................. 621

Corn Crake................................. 603

Snake ................................. 647

cornubica, Lamna.......................... 663

cornuta, Eremophila..................... 528

cornutus, var. cornutus, Minnilus.... 678 Podiceps ...................... 631

coronata, Dendroica..................... 557

Coronella.................................. 647

corporalis, Semotilus...................... 679

Corvidæ...................................... 529

Corvina ................................739, 740

Corvus.................................. 529

Coryphæna .................................. 722

Coryphænidæ ............................. 721

Coryphodon .............................. 645

cosmopolita, Seriola ...................... 717

Cottidø ...................................... 748

Cottus ........................748, 749, 750

Cottopsis ................................ 749

Coturniculus passerinue.................. 541

Coturnix ................................. 584

coturnix, Coturnix ..................... 584

Gotyle ...................................... 550

Cow Bird................................. 531

Cowfish.............................516, 765

Cow-nosed Ray............................ 666

Crab eaters............................709, 710

Crámpfish ............................... 664

crassus, Lepidosteus .................... 670

Crawl-a.bottom ......................... 674

crecca, Anas ............................ 612

Creekfish................................. 675

Creepers ......................................... 568

Creolus..................................... 733

crepitans, var. of Acris gryllus ....... 651 var. of Rallus longirostris, 601 Rallus (roferred to)........ 509

Crested Diver............................. 610

Grebe............................. 632

Crevallé................................715, 716

Crex ...................................... 603

crex, Crex................................. 603

Cricket Frog.............................. 651

Crimson-spotted Triton................. 656

crinitus, Blepharis ....................... 716

Daranx........................ 715

Myiarchus...................... 526

cristata, Condylura ...................... 498

Cyanocitta (referred to, 540), 529

cristatus, Colymbus..................... 632

Pavo (referred to)............ 586

Croaker.................................... 740

Croakers ................................... 738

cromis, Pogonias ....................... 739

Crossbills...........................537, 538

Cross Fox .................................. 508

Crotalidæ .................................... 648 
Crotalus ................................... 648

Crow... ................................... 574

Crow Blackbird........................ 535

Crows ..............................529, 530

crumenophthalmus, Caranx ............ 715

Crymophilus.............................. 588

cryptosus, Rhombus.................... 721

Ctenolabrus ................................ 743

cubifrons, Malthe ...................... 765

Cuckold........................................ 765

Cuckoos ....................................... 522

cucullatus, Lophodytes .................. 610

Cucnli....................................... 522

Cuculidx ................................... 522

cunicularia, Speotyto..................... 582

Cunner ...................................... 743

cupido, Cupidonia........................ 585

Cupidonia .................................. 585

cupreus, var. of Amiurus natalis..... 672

curema, Mugil.......................... 706

Curlews.................................. 597

Curlew Sandpiper........................ 592

Cursores ................................... 583

curtus, Vomer.............................. 717

Curvirostra................................ 537

curvirostra, var. minor, Loxia ........ 537

cuspicauda, Alutera..................... 767

Cusk ....................................... 757

Cutlass-fish .............................. 711

Cutwater.................................... 631

cyanea, Passerina.......................... 546

Cyanocitta.................................. 529

Cyanocitta cristata (referred to)...... 540

cyanonoton, Alosa........................ 685

Cyanura.................................. 629

Cyclophis..................................... 646

Cyclopteridx ............................. 752

Cyclopteris ................................ 753

Cyclostomi............................... 657

cyclotis, Ceratichthys................... 679

Oygnus...................................... 620

Cynocephalus.............................., 660

Cynoseion .................................... 741

cypho, Esox............................... 696

Cyphosus................................. 738

Cyprinella ................................. 677

Cyprinidø.................................. 676

Cyprinodon .........................692,694

Cyprinodontidær........................6 692

Cyprinus ...............674, 679, 681, 682

cyprinus, Ictiobus........................ 674

Cypseli ...................................... 523

Cypeelidæ ................................. 524

Cypselurus ................................. 701

\section{D.}

Dab. chick .............................. 632 Dace ......................678, 679, 680, 681

Dactylopterus .......................... 752
Dafila ................................... 613

Darters ...................................728, 729

Dasyatis .................................... 666

Dasybatis ................................. 666

Day Owl................................. 582

Decapterus ............................... 714

decumanus, Mus......................... 504

Deer ....................................... 513

Deer Mouse................................. 505

defensor, Garanx......................... 716

deglandi, Oidemia...................... 618

dekayi, Gasterosteus..................... 704

Isuropsis ....................... 663

Isurus..........................6 663

Phycis ........................... 757

Pimelodus...................... 672

Pygosteus ...................... 704

Scomber ....................... 712

Scomberomorus................. 713

Storeria ........................ 644

De Kay's Brown Snake................. 644

Shrew ......................... 496

delawarensis, Larus..................... 627

delicata, Gallinago........................ 589

Delphinus................................ 515

see Globicephalus .......... 517

see Grampus ............... 516

see Phoccena ................... 516

Delphinus intermedius.................. 517

delphinus, Phocæna.................... 516

delphis, Delphinus......................... 515

Dendroica .................................. 556

dentata, Pomatopsetta ................... 761

dentatus, Paralichthys ................... 761

Denticete ................................ 515

Diodon ................................... 768

Diplodus .................................. 738

deprandus, Esox............................. 696

Dermochelydidø ........................ 640

Dermochelys .............................. 640

Desmognathidæ .............................. 653

Desmognathus ............................... 653

Descriptions ................................... 490

Devil Diver..................................... 632

Devil-fish ...................................... 667

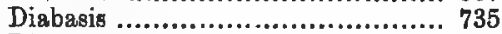

Diacope...................................... 734

Diadophis ................................ 646

Diamond-back Turtlo.................... 639

diaphanes, Raia ........................... 664

diaphanns, Fundulus..................... 693

Diapterus...................................... 742

Didelphia ................................... 492

Didelphidæ................................... 517

Didelphys ................................... 517

Diedapper..................................... 632

Diemyetylus................................. 652

dilophus, Phalacrocorax................. 622

discolor, Dendroica.......................... 560

discors, Anas........................... 611 
Ditch Pike........................... 696

Diver....................................... 633

Diving Birds.............................. 631

Dogfish ..............................660, 695

Dogfishes ................................. 659

Dogs ...................................... 508

Dog Shark............................... 660

doliatus, Ophibolus....................... 647

Dolichonyz............................... 531

Doliodon.................................... 718

Dollar-fish ................................. 721

dolomiei, Micropterus..................... 728

Dolphins (Fishes) ...................... 721

Dolphin (Mammal)..................... 515

domestica, var. of Columba livia...... 584

Gallus (referred to)......... 586

Spizella ...................... 543

domesticus, Passer......................... 539

Troglodytes ................. 566

dominica, Dendroica..................... 559

dominicensis. Tyrannus................ 526

dominicus, Charadrius ................ 597

Nomonyx.................... 619

dorsalis, var. of Eutænia sirtalis....... 645

Semotilus........................ 679

dorsatus, Erethizon........................ 507

Dorosoma .. ............................. 687

Dorosomatidæ... ........................ 687

Dory .. $\quad \ldots \ldots \ldots \ldots \ldots \ldots \ldots \ldots . . .716,718,731$

dougalli. Sterna.......................... 630

Dough Bird.............................. 597

Double-crested Cormorant............. 622

Donble-bearded Flying-fish............ 701

Dovekio .................................... 636

Doves ........................................ 583

Dowitcher...................................... 590

Downy Woodpecker.................... 519

dresseri, Somateria....................... 617

Drumfish (referred to) .................. 516

drummondii, Otolithus .................. 741

Dryobates............................... 518

Dubertus (referred to)................. 514

Dack Hawk............................... 577

Ducks..................................... 609

ductor, Naucrates........................ 718

Dules.. ................................... 734

Dusky Bat.............................. 495

Duck ............................... 611

Salamander ........................ 653

Shark,............................ 660

duodecim, Engranlis.................... 688

F.

Eagle ...................................... 577

Eagle Rayв................................... 666

Eared Grebe............................... 632

Easter Mackerel......................... 712

Eastern Hemitremia...................... 677

Pickerel........................6 696
Eastern Red Horse.................... 675

Eaves Swallow ........................... 549

Echelus ......... ............................... 698

Echen $\theta i d e 9$................................ 708

Echeneis................................. 708

Ectopistes................................... 583

Eelpouts .................................. 755

Fiels ...................................697, 698

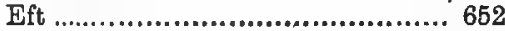

eglanteria, Raia.......................664, 665

Egret...............................607, 608

egretta, Ardea........................... 607

Eider Ducks................................. 617

Elacate ...................................... 710

Elacatidø ................................. 709

Elanoides................................. 574

Elasmobranchii ............................ 659

elegans, Rallus.......................... 601

Electric Rays............................. 664

ellipticus, Chatoëssus.................... 687

elongata, Clupea......................... 684

Elopidæ ................................... 683

Elops........................................ 683

emarginatus, Neomænis................ 734

Empidonax............................. 527

Emydidx .................................6 637

Enchelyopus ...........................755, 756

Enchylycephali ......................... 697

English Sparrow....................... 639

Teal............................. 612

Engraulididæ............................. 688

Engranlis .................................. 688

Enneacanthus........................... 725

enucleator, var. canadensis, Pinicola, 537

eos, var. of Chrosomus ery throgaster.. 676

Ephippidø............................... 744

Ephippus................................. 744

Epinephelus..........................733, 734

equisetis, Coryphæna.................. 722

erate, Lobotes.............................. 736

erebennus, Tursiops ..................... 515

er emophila, Cornuta.................... 528

Erethizon ................................ 507

Ereunetes ................................... 593

Erimyzon .................................. 675

erinacea, Raia ............................. 664

Erismatura.............................. 619

Ermine ...................................... 510

ermineus, Putorius....................... 510

erythrocephalus, Melanerpes........... 520

erochrous, Pœcilichthys.................. 730

erythrogaster, Chelidon................... 549

var. e0s, Chrosomus.... 676

Epinephelus ........... 734

erythromelas, Piranga................... 547

erythrophthalmus, Coccyzus............ 522

Pipilo............... 545

erythrorhynchus, Pelecanus............. 622 erythronotus, var. of Plethodon cinereus 
esculentus, Carangus.................... 716 Esox....................682, 693, 695, 699

Esquimaux Ourlew ..................... 597

estor, Esox................................. 696

Estrella................................... 728

Etheostoma....................728, 729, 730

Etheostomatidæ ......................... 728

Etrumens................................. 684

Eubalæna ................................ 514

Euchalarodus.............................. 762

Eucinostomus............................ 742

Eudocimas................................ 604

Eudytes ..................................... 633

Eudytidæ................................... 633

Enlamia:................................... 660

Euleptorhamphus........................... 700

Eumeces .................................... 642

Eapomotis................................ 726

European Carp............................. 682

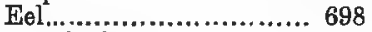

Goldfinch ................... 539

House Sparrow............... 539

Quail .......................... 584

Teal .......................... 612

Widgeon.......................... 612

Woodcock .................... 589

Eutænia ................................. 644

eurystole, Stolephorus.................... 688

Eventognathi.... ......................... 673

Evet ......................................... 652

evolans, Halocypselus ................... 700

Prionotag ....................... 751

Evotomys ............................... 505 excubitorides, var. of Lanias ludovi-

cianus................................... 552

exilís, Botaurus......................... 606

exiliens, Exocotus........................... 701

eximia, Coronella......................... 647

eximius, Cyprinodon..................... 692

Exoccotidæ .................................... 699

Exocostus .................................700, 701

exsiliens, Exoccetus..................... 701

\section{F.}

faber, Chætodipterus..................... 744

falcatus, Caranx........................... 715

Falco Trachynotus................... 718

Falconidæ..................................... 574

Falcons ................................... 574

Falco sparverius (referred to).......... 540

falcinellus, Plegadis...................... 605

Fallfish....................................... 680

Fall Herring................................. 684

Mackerel............................, 712

familiaris, var. americana, Certhia, 568

Fan-tailed Darter......................... 729

fasciata, Amblystoma ................... 655 fasciata, Melospiza ..................... 544

Seriola........................ 719

fasciatus, Achirus........................... 763.

Bryttus........................... 725

Esoz ............................ 695

Eumeces ...................... 642

Grystes ......................... 728

Pogonias......................... 739

Fat-back Syngnathus ..................... 702

Fatbird ........................................ 591

fedoa, Limosa........................... 593

Felidæ .......................................... 508

felis, Arius................................... 673

Fence Lizard............................ 641

Feræ .....................................498, 508

ferina, Aythya............................. 614

ferruginea, Tringa...................... 592

ferrugineus, Scolecophagus............... 534

Fiber ....................................... 506

fiber, Castor................................. 503

Field Mice.................................., 492

Mouse ............................. 506

Plover .............................. 596

Sparrow .......................... 543

Filefish ....................................766, 767

filamentosus, Phycis....................... 757

fimbriatus, Zoarces.......................... 755

Fin-back Whale (referred to)........... 514

Finches ................................. 537

Fine-scaled Sucker....................... 674

Fire Bird................................... 534

Tanager .............................. 547

Fisher.................................... 509

Fishes ................................492, 657

Fish Crow................................ 530

Duck ........................609, 610

Hawk................................. 578

Fishing-frogg................................ 763

Fistularia .................................... 703

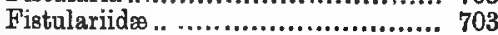

fiabellare, Etheostoma................... 729

Flasher ........................................ 736

Flat Fishes................................. 759

flavescens, Bodianus...................... 731

Brosmius ..................... 757

flavifrons. Vireo............................. 553

flavipes, Totanus.. ...................... 594

flaviventris, Empidonax................. 528

flavolineatus, Pimelepterus............... 738

flavulus, Esox................................ 693

flavus, Noturus,............................. 671

Flicker (referred to, 572)................ 521

Florida................................... 607

Florida Gallinulo......................... 603

floridana, Cichla............................. 727

Neotoma ......................... 505

floridensis, Fundulus...................... 693

Flounders................759, 760, 761, 762

Fluk $\theta$..................................... 762 
fluviatilis, Hudsonius...................677

Perca ........................ 731

Flycatcher .............................. 570

Flycatchers .............................. 552

Flying Gurnard........................ 752

Flying-fish..................700, 701, 751

Flying-fishes .............................. 699

Flying Squirrel......................... 501

Fly-up-the-Cre日k........................ 608

footens, Synodus.......................... 689

fontinalis, Rana............................ 649

Salmo ........................ 691

Foolfish .............................766, 767

Foolish Guillemot...................... 635

forficatus, Catonotus ................... 729

Elanoides.................... 574

Milvalus ................... 526

Fork-tailed Flycatcher.................. 525

Gull........................ 628

formosa, Geothlypis...................... 561

Perca, Hæmulon.............. 735

forsteri, Sorex............................ 496

Sterna......................... 629

Forster's Tern................................ 629

Four-bearded Rockling.................. 756

Fourteen-laminated Remora.......... 709

Four-toed Salamander.................. 654

Fox-colored Sparrow....................... 545

Fox Shark.............................. 662

Snake.............................. 646

Sparrow............................ 545

Squirrel............................ 500

Fratercula ............................... 634

freminvillei, Myliobates.................. 666

frenata, Sterna............................ 630

Fresh-water Marsh Hen............... 601

Sculpin.................. 749

Friar ..................................... 707

Frigate Mackerel....................... 712

Fringed-tongue Warbler................ 556

Fringillid $\circledast$............................... 537

frcenatus, Prodelphinus................. 515

Frogs..................................... 649

Frog-fishes................................ 764

Frost-bird .............................. 597

Frost-fish............................689, 758

frugivoras, Corvas...................... 530

fucorum, Blennius......................... 754

Fulica ..................................... 604

Fulica americana (referred to)........ 633

fulicarius, Crymophilus................. 588

faliginosa, Sterna....................... 630

fuliginosus, Balistes .................. 766 var. of Chilomycterus

geometricus............... 769

Fuligula .................................... 615

Fulix.......................................... 615

Fulmar ...................................... 623

Fulmarus.................................... 623

fulyomaculatus, Pomadys ............. 735 funduloides, Squalius ................. 681

Fundulus ............................693, 694

funerea, Surnia ......................... 582

furcatus, Cypselurus .................... 701

furcifer, Creolus .......................... 733

fusca, Desmognathus ................... 653

Oidemia .............................. 618

fuseescens, Turdus....................... 571

fuscicollis, Tringa........................ 591

fuscum, Siphostoma................... 702

fuscus, Accipiter......................... 574

var. carolinensis, Vespertilio.. 495

var, fuscus, Vespertilio......... 495

Sayornis......................... 527

Veepertilio....................... 495

Fusiform Darter......................... 730

fusiformis, Pœcilichthys ................ 730

\section{G.}

Gadidæ ................................. 756

Gadus...............................757, 759

Gadwall ....................................... 612

Gaff-topsail.............................. 673

Gaff-topsail Pompano.................... 718

galbula, Icterus......................... 534

galeata, Gallinula ...................... 603

Galeocerdo................................ 660

Galeorhinidæ .............................. 660

Galeoscoptes .............................. 565

Galeus ....................................... 660

Gallinæ ................................... 584

Gallinago.................................... 589

Gallinula .................................. 603

Gallus...................................... 586

gallus, Caranx............................... 715

gallopavo, Meleagris ................... 586

gambeli, var. of Anser albifrons...... 619

Gannet .................................... 621

Ganoidei ................................... 668

gardeniana, Hiatula .................... 743

gardeni, Nyctiardæ....................... 609

Stromateus ..................... 720

Gar (referred to)......................... 680

Garfishes ................................... 699

Gar Pike...................................... 669

Garrot ...................................... 615

garrulus, Ampelis ......................... 550

Garter Snake.............................. 643

Garzetta .................................. 608

Gasperea.1................................. 684

Gasterosteidæ ................................ 704

Gasterosteus .............704, 705, 720, 752

Gastrophysus.............................. 768

Gelochelidon .............................. 628

geographicus, Malacoclemnys .......... 638

geometricus, Chilomycterus ............ 769

georgiana, Melospiza ..................... 544

German Duck............................ 612 
Gerres.

742

742

Gerridæ .................................... 647

gibbifrons, Exocotus .................... 701

gibbosus, Aphredoderus ................ 723 Lepomis....................... 727

gibbus. Antennarius.................... 764

gigas, Ephippns....................... 744

Gilt-head ................................. 736

gilvus, Vireo ............................ 553

Ginglymodi ............................... 669

Gizzard Shad.............................. 687

glaber, Pleuronectes .................... 762

glacialis, Fulmarus .................... 623

Harelda ....................... 616

Heuronectes................... 7t2

Urinator ........................633

Gladiator Dolphin....................... 517

gladiator, Orca............................ 517

gladius, Xiphias ........................ 710

Glaniostomi............................... 668

Glass-eye................................ 731

glanca, Isurus......................... 663

Glancionetta.............................. 615

Glancous Gull........................... 626

glaucus, Larus........................... 626

Trachynotus.................. 718

Glires..................................... 492

Globefish................................. 769

Globicephalus ........................... 517 see Grampus........... 516

Glossy Ibis............................. 605

gloveri, Salmo............................. 690

Glut Herring.............................. 685

glutinosa, Myxine...................... 657

glutinosus, Plethodon.................... 654

Glyptemys ............................... 638

Gnatcatcher............................. 570

Goateuckers............................... 523

Gobies ...................................... 747

Gobiidæ............................... 747

Gobio ..................................... 678

gobio, Cottus............................ 749

Gobiosoma ................................ 747

Gobius...................................... 747

Goby ..................................... 747

Godwita (et seq.)....................... 593

Goggle.eye............................. 724

Goggler...................................... 715

Golden-crested Wren..................... 569

Golden-crowned Kinglet................ 569

Thrush................ 560

Golden-eyed Dack........................ 615

Golden Eagle............................ 577

Robin ......................... 534

Shiner ........................ 681

Warbler......................... 556

Golden-winged Woodpecker.............. 521

Goldfish..................................... 682

Gold-thread Roach......................... 681
Gold-thread Shiner...................... 681

Goody ...................................... 740

Goosander ................................. 609

Goosefish............................... 763

gracilis, Perca............................. 731

Uranidea .................... 749

Graculus ............................... 621

Grallæ............................587, 601

Grallæ-Limicolæ ........................ 587

Grall $\infty$.Paludicolæ.......................6 601

Grallatores ............................ 587

gramineus, Poocretes...................... 542

grammacus, Chondestes................. 542

Grampus .................................. 516

grandis, Fundulus...................... 693

Graptemys ............................. 638

Grass Bass................................. 724

Finch ............................ 542

Snake .......................... 646

Snipe .............................. 591

Grasshopper Sparrow................... 541

Gray and Black Squirrel.............. 500

Gray Fox ................................ 509

King-bird ....................... 526

Owl ............................... 581

Rabbit............................ 507

Salamander ....................... 654

Snapper ........................... 734

Snipe ............................ 590

Squirrel ........................... 501

Trout............................. 741

Great Aak (referred to)............... 636

Black-backed Gull............... 626

Blue Heron......................... 606

Crested Flycatcher .............. 526

Dolphin............................ 722

Gray Ow1......................... 580

Horned Owl..................... 581

Lake Pike......................... 696

Marbled Godwit.................. 593

Northern Loon..................... 633

Northern Shrike .................. 551

Bea Lamprey...................... 658

White Egret........................ 607

Greater Redpoll.......................... 538

Snow Goose..................... 619

Shearwater..................... 623

Tell-tale.......................... 594

Yellow-lege ................... 694

Grebes ................................... 631

Green and Yellow Tree-toad........... 651

Green Bags................................ 727

Black-cap Flycatcher........... 563

Black-capped Flycatching

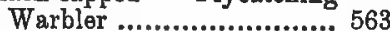

Cod ........................... 758

Greenfish .................................. 720

Green Frog .............................. 649

Heron ......................... 608

Greenlets ................................... 552 
Green Pike

Snake..

Tree-toad

Green-winged Teal.

grex, Scomber.

Macrortampus................ 516

Mesoprion ....................... 734

grisea, Nycticorax ....................... 609

griseigena, Podiceps..................... 632

Groper....................................... 733

Ground Bird................................ 542

Ground-hog............................. 502

Ground Snake .......................... 647

Squirrel ......................... 502

Grouse..................................... 584

Grubby .................................... 750

grylle, Cepphus........................... 634

grylins, var, crepitans, Acris............. 651

Grystes ...............................727, 728

guaguancho, Sphyræna................. 707

Guara..................................... 604

Gubartas (referred to).................. 514

Guillemots ................................ 634

Guinea Fowl (referred to).............. 586

Guiraca ................................... 546

gula, Gerres............................... 742

Gulls........................................ 626

Gull-billed Tern......................... 628

Gunnellus............................. 754

gunnellus, Murænoides.................. 754

Gurnards ................................ 751

guttata, Coryphæna..................... 722

guttatua, Enneacanthus................. 725

Nanemys ................... 638

Percopsis ...................... 691

Pomotis ....................... 725

Upsilonphorus ............746, 747

Gyrinophilus............................ 655

gyrinus, Noturus........................ 671

\section{H.}

Habia 546

Haddock ...................................... 757

hæmastica, Limosa...................... 594

Hæmatopodidæ............................. 600

Hæmatopus ................................. 600

Hæmulon .................................... 735

Hæsitata ...................................... 624

Hagfishes .................................. 657

Hair Bird................................... 543

Hair-finned Silver-fish..............716, 717

Hair-trils.................................. 711

Hairy-tailed Mole........................ 498

Hairy Boxfigh.............................. 768

Woodpecker ....................... 518

Hake.....................................757, 759

Halatractus..........................718, 719 halecina, Rana........................... 649

Haliæëtus ............................... 577

haliaëtus, vor, carolinensis, Pandion.. 578

Halibut.................................. 761

Half-beak .................................... 700

Halocypselus ............................. 700

Hammerheads............................... 661

Hammerhead Sucker................... 674

Haplochilus................................... 694

Haplomi ................................... 692

Harbor Porpoise.......................... 516

Seal .............................. 508

Hard-tail ................................... 715

harelda, Glacialis......................... 616

harengus, Clupez......................... 684

Harlequin Duck........................ 617

Harmless Snakes.......................... 643

Harporhynchus .......................... 565

hastata, Alstrelata......................... 624

Trygon.............................666 666

Harvert-figh.............................720, 721

Hawks .................................... 574

Headfish ................................... 770

Headfighes .................................... 768

Hedge-hog Ray........................... 664

Heath Hen............................... 585

Hell-diver ................................... 632

Helminthophila .......................... 554

Helmitherus............................... 554

helvetica, Squatarola...................... 598

Hemibranchii.............................. 703

Hemidactylium ........................... 654

Hemidurgan................................ 748

Hemirhamphus........................... 700

Hemirhombus .............................. 760

Hemioplite日................................. 725

Hemitremia ................................. 677

Hemitripterus ............................. 748

Hemlock Warbler........................ 559

henslowi, Ammodramus................. 541

Henslow's Sparrow...................... 541

heptagonus, Hippocampus............ 702

Herbivora................................. 513

Hermit Spadefoot........................ 650

Thrush ......................... 571

Herodias............................... 607

herodias, Ardea............................. 606

Herodiones....... ........................... 604

Herons...................................604, 605

Herrings ................................... 683

Herring (referred to, 578).............. 684

Ferring Hog ........................... 516

herschelii, Tetrapturus.................. 711

Hesperocichla ............................ 572

Hesperomys ............................... 505

heteroelitus, Fundulus.................. 693

Heterodon .................................. 643

Heterosomata............................ 759

heterurus, Exocoetus....................... 701

hexacanthus, Centrarchus................ 724 
Histula

hiatula, Labrus

Hickory Shad

hiemalis, Troglodytes.

hieroglyphica, Pseudemys.

Hieroglyphic Turtle.

High-holer.

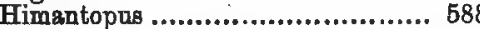

himantopus, Micropalama.............. 590

hinnulus, Mustelus...................... 660

Hippocampidø ............................ 702

Hippocampus.............................. 702

hippocampus, Syngnathus.............. 702

Hippoglossoides.......................... 761

Hippoglossus............................. 761

hippoglossus, Pleuronectes.............. 761

hippos, Carangus.......................... 715

Caranx .......................... 716

Paratractas....................... 715

hipparus, Coryphæna..................... 722

hirundo, Sterna........................... 629

Hirundinid $\approx$............................ 549

hispidus, Monacanthis................... 766

Histrionicus ........................... 617

histrionicus, Histrionicus................ 617

histrio, Pterophrynoides................. 764

hiulcus, Engranlis........................ 688

Hoary Bat................................... 495

Hoe Shark............................... 659

Hog Choker................................ 763

Hogfish.... ...........................729, 735

Hog-nose Snake ........................6 643

Hog Molly............................... 674

Hog Sucker ............................... 674

Holacanthus ............................... 745

Holbcell's Grebo......................... 632

holbœllii, Colymbus..................... 632

holbrooki, Echeneis....................... 708

Scaphiopus..................... 650

Holocentrus ................................ 736 Hololepis....................................729, 730

Holostei .................................... 669

Holostomi................................. 697

homonymus, Gerres..................... 742

Hooded Flycatching Warblers........ 563

Merganser ...................... 610

Warbler .......................... 563

Hoofed Mammals .......................... 513

Hop-toad .................................. 652

horiconensis, Rana......................... 649

Horned Chab............................... 679

Dace.............................. 679

Grebe ................................. 631

Lark .............................. 528

Owls ............................ 579

Pout................................ 671

Horny-head ................................... 679

horridus, Crotalus.......................... 648

Horsefish .................................. 717

Horsehead ..................................... 716
Horse Crevalle........................... 716

Mackerel........................ 714

House Snake........................644, 647

Wren (referred to, 567)......... 566

hoyi, Sorex............................... 497

Hoy's Shrew............................. 497

hudeonia, Cliola........................... 677

Hudsonian Curlew........................ 597

Godwit..................... 594

hudsonica, Limosa........................ 594

Lutra............................ 510

h\&dsonicus, Numenius................. 597

Salmo ....................... 691

Hudsonius.................................... 677

hudsonius, Circus.......................... 574

Hippocampus............... 703

Sciurus ...................500, 501

Zapus ....................... 503

humeralis, Oligocephalus............... 729

Humming Birds ......................... 524

Hump-back Pickerel..................... 696

Huro ....................................... 727

huronensis, Lepidostens................. 669

Hybognathus........................676, 677

Hybopsis ...............................677, 679

Hyborhynchus ............................. 676

Hydrargyra...........................693, 694

Eydrochelidon ............................ 630

hyemalis, Clangula....................... 616

Junco ......................... 544

Hyla .......................................... 650

Hylidæ...................................... 650

Hylomyzon .................................. 674

Hylotomus.............................. 520

Hypentelinm ...............................6.674

hyperborea, var. nivalis, Chen.......... 619

hyperboreus, Lobipes................... 587

Hyperoartia...............................6.657

Hyperotreta ................................6.657 657

hypochrysea, var. of Dendroica pal-

marum .............................. 560

hypogæa, var. of Speotyto cunicularia

Hypsilepis.............................677, 678

Hystricidæ ................................... 507

\section{I.}

Ibididæ ...................................6 604

Ibises........................................... 604

Ibis ordii....................................... 605

Ice Gull ......................................... 626

Iceland Gull.................................. 626

Ichthyomyzon ........................... 658

Ichtholis ................................... 726

Ictalurus ......................................... 672

Icteria....................................... 562

Icteridæ (referred to, 537).............. 531

Icterus......................................... 534 
Iotiobus.

Iguanidæ

674

iliaca, Passerella......................... 545

imber, Urinator ........................... 633

immaculata, Coryphena................ 722

immactalatus, Salmo..................... 691

immer, Urinator............................. 633

impennis, Plautus (referred to)........ 636

Indian Hen................................. 605

Remora.......................... 709

indicus, Tetrapturus...................... 711

Indigo Bunting......................... 546

ingens, Amblystoma.................. 656

insculptus, Calemys..................... 638

Insectivora ................................ 496

Ingessores ............................... 525

insignis, Noturus........................... 681

intermedius, Delphinus, see Globice-

phalus ................................. 517

interpres, Arenaria..................... 600

Ionornis................................ 603

Ipswich Sparrow........................... 541

Isabelita................................... 745

Isognatha ................................ 698

Isogomphodon. .......................... 661

isolepis, Aphredoderus ................ 723

Isospondyli .............................. 682

Istiophoridæ............................ 711

Isuropsis ................................ 663

Isarus...................................... 663

\section{J.}

Jack Curlew.............................. 597

Salmon ............................. 731

Snipe............................ 591

jacobæa, Remora....................... 709

Jaegers.................................. 625

jamaicensis, Porzana...................... 602

jeffersonianum, Amblystoma ......... 656

Jefferson's Salamander................. 656

Jerker .................................... 679

Jew figh ..................................... 683

Johnius .................................... 741

Jordan \& Gilbert........................... 490

Jordan, Professor ........................ 490

Jumping Mouse (referred to, 605).... 503

Jungle Fowl (referred to).............. 586

Junco....................................... 544

Jurel................................... 715

\section{K.}

Kennicott quoted

kentuckiensis, Ceratichthys............. 679

Kentucky Warbler
Killdeer (referred to, 590)............ 598

Killer ..................................... 517

Killiefieh ..................................... 692

Killifish .................................... 693

Kingbird.................................... 526

King Eider............................... 617

Kingfish .................................. 741

Kingfishes .............................. 522

Kinglet ................................. 569

King Plover................................ 599

Rail................................... 601

Snake............................. 647

kirtlandi, Dendroica..................... 559

Tropidoclonium ............... 644

Kirtland's Warbler........................ 559

Kittiwake Gull.......................... 626

Knot........................................ 591

L.

Labidesthes .............................. 707

Labrador Dack.......................... 617

labradorius, Camtolaimus................ 617

Labrax.................................... 732

Labridø ................................. 742

làbrosus, Zoarces.............................. 755

Labrus....724, 726, 727, 735, 739, 741, 743

Lacertilia................................ 641

Lady-fighes................................... 682

lævicaudatus, Hippocampus............ 702

lævigatus, Chironectes.................... 764

Lagocephalus .............. 768

lævis, Raia................................ 665

La Fayette............................721, 740

Lagenorhynchus ........................ 516

Lagocephalus................................. 768

Lagodon ................................. 737

lagopus, var, sancti-johannis, Archi-

buteo ...................................... 576

Lake Mullet................................... 675

Lamellirostres............................. 609

Lamna......................................660, 663

Lamnidæ ................................... 662

Lamnoidea ................................ 661

Lampreys ................................. 657

Lamprey..................................... 658

Lampropeltis ............................. 647

Lampugus ................................. 722

Laniidm....................................... 551

Lanius .......................................... 551

Lanius borealis (referred to)........... 540

Lant ....................................... 708

Lapland Longspur........................ 540

lapponicus, Calcarius.................... 540

Large Killifish. ........................... 693

Large-mouthed Black Bass............ 727

Large-scaled Sucker...................... 675

Large-spotted Salamander............... $65 \hbar$

Larid $¥$......................................... 626 
Larks

Bonting.......... 547

Finch................................. 542

Sparrow ............................ 542

Larus

Lasiurus ..................................... 494

latissimus, Buteo........................ 575

latus, Caranx............................. 715

Laughing Goose....................... 619

Gall ...........................6.627

lawrencei, Helminthophila............. 554

Lawrence's Warbler..................... 554

Lawyer ................................... 588

Leach's Petrel ............................. 624

Least Bittern............................. 606

Darter............................ 730

Flycatcher ........................ 528

Sandpiper .......................... 592

Sculpin .......................... 750

Tern 630

Leather Jacket......................719, 766

Snake ........................... 643

Turtle $\ldots . \ldots \ldots$.

Leathery Turtle.......................... 641

Lebias ...................................... 692

leberis, Regina........................... 643

Tropidonotus .................... 643

Leirus .................................. 721

lentiginosus, var. americanus, Bufo, 652 Botaurus................. 605

Leopard Frog ........................... 649

Lepidosteidæx ........................... 669

Lepidosteus (referred to, 680).........669 669

Lepomis .......................724, 726, 727

Leporidæ ................................. 507

Leptocephalus.............................. 698

Lepturus................................... 711

leptarus, Trichiuras..................... 711

Lepus ..................................... 507

Le日ser Redpoll Linnet................... 538

Scaup Duck..................... 615

Tell-tale ....................... 594

Louciseus ...........581, 676, 677, 678, 680

lencobronchialis, Helminthophila.... 555

leucocephalus, Haliæëtus................ 577

leucophrys, Zonotrichia................. 542

leucopsis, Brantr......................... 620

lencoptera, Loxia............................ 538

leucopteras, Larus....................... 626

leucopus, Hesperomys................. 505

lencorhoa, Oceanodroma.............. 624

Loucosomus.............................679 681

Limanda ................................. 762

limandoides, var. of Hippogloss-

oides platessoides..................... 762

limbatus, Isogomphodon................ 661

Limicolæ.................................... 587

limi, Umbra.................................. 695

Limosa ................................... 593

lim0sa, Myzine.......................... 657 linaria, Acanthis........................ 538

var. rostrata, Acanthis........ 538

lincolni, Melospiza ..................... 544

Lincoln's Finch............................ 544

Sparrow ...................... 544

lineata, Alosa.............................. 684

Echeneis ...................... 708

lineatus, Achirus........................ 763

Buteo........................ 576

Micropogon ..................... 740

Mugil ......................... 706

var. of Prionotus sarritor... 751

Roccus....................... 732

Ling........................................710, 757

Linnets .................................538, 539

Liopeltis .................................... 646

Liopsetta ................................... 762

Liostomns........................................ 740

Lirus ............................................ 721

Little Auk................................... 636

Barracuda .......................... 707

Black Rail......................... 602

Blue Heron....................... 607

Brown Bat........................... 495

Killiefish ......................... 694

Pickerel ................................ 696

Red Owl............................ 581

Sapsucker ........................ 519

Skate.............................. 664

Star-gazer ....................... 749

Top Minnow..................... 694

Tree-frog............................ 652

White Egret...................... 608

littoralis, Squalus........................ 662

Odontaspis .................... 662

lividus, Silurus............................. 672

livia, var. domestica, Columba......... 584

Liza.......................................... 706

Lizard-fish............................... 689

Lizards..................................... 641

lobatus, Phalaropas........................ 587

lobipes, hyperboreus........................ 587

Lobotes..................................... 736

Lobotidm ................................. 736

loculator, Tantalus.......................... 605

Loggerhead Shrike....................... 552

Turtle $\ldots \ldots \ldots \ldots \ldots \ldots . . . . . . .640$

Log Pereh.................................. 729

lomvia, Uria................................. 635

Long-billed Curlew....................... 597

Dowitcher................... 590

Marsh Wren............... 567

Water Thrush............ 561

Long-eared Bat ............................ 495 Sunfish ...................... 720

longicauda, Bartramia.................... 596

longicaudus, Spelerpes..................... 655

Stercorarius ..............6 625

Longipennati ............................. 623

Longipennes ................................ 625 
longipinnis, Rhombns.................. 720

longirostris, var, crepitans, Rallus.... 601

Esox...................... 699

Euleptorhamphus ....... 700

Numenius.................. 597

Long.jawed Catfish......................... 672

Long-nosed Dace............................. 678

Gar........................ 669

Long Shanks ............................... 588

Long-tail Shark.......................... 662

Long-tailed Duck ........................... 616

Jaeger ........................ 625

Shrew ..................... 496

Loons ......................................... 633

Lophiidæ ..................................... 763

Lophins .......................763, 764, 765

Lophobranchii ........................... 701

Lophodytes ............................. 610

Lophopsetta .................................. 760

lotor, Procyon............................ 512

Lonisiana Heron.......................... 608

Tanager......................... 548

Loxia ........................................... 537

Lucania ..................................... 694

luciø, Hydrargyra ....................... 694

lucifugus, Vespertilio...................... 495 var. of Vespertilio subu-

latus ..................... 496

Lucioperca .............................. 731

lucius, Esox............................695, 696

lucifugus, Vespertilio.................495, 496

ludoviciana, Habia..................... 546

Piranga..................... 548

ludovicianus, Anthus................... 564 var. excubitorides, Lanius .................. 552 Lanius..................... 552

Seiurus .................... 561

lumme, Urinator

Lumpfish ................................... 753

Lump Sucker..........................752, 753

Lumpus..................................... 753

lumpus, Cyclopterus........................ 753

lunifrons, Petrochelidon................. 549

lupus, Anarrhichas....................... 755

Lutjanue ................................... 734

Intra.................................... 510

Luxilus .........................676, 677, 678

Lurilus americanus....................... 681

Lycodid $\circledast$.................................. 755

Lynx ..................................... 508

Lythrarus.............................. 678

M.

macarellus, Decapterus

Machetes.
Mackerels.

$.712,713$

Mackerel Scad........................... 715

Shark .........................6. 663

macrocephalus, Anguilla................ 698

Gadus ................... 758

Gunnellus ............. 754

Physeter (referred

to) .................. 514

Macrochires............................... 523

Macrorhampus .......................... 590

macrolepidotum, Moxostoma.......... 675

macrura, Ectopistes..................... 583

Sterna .......................... 629

macroura, Zenaidura...................... 583

macularia, Actitis......................... 596

maculata, Tringa........................ 591

maculaticeps, Boleosoma.:............. 728

maculatum, Cynoscion ................ 741 var. of Labrus squeteague................... 741

maculatus, Bothus........................ 760

Galeocerdo ................ 660

Necturus....................6 656

maculosa, Dendroica..................... 557

maculostriatus, Diodon.................. 769

magna, Sturnella......................... 533

Magnolia Warbler ....................... 557

majalis, Fundulus......................... 693

major, Puffinus............................. 623

Malacoclemmy8........................... 638

Mallard Duck............................. 610

malleus, Zygæna.......................... 661

Malthe ...................................... 765

Malthidæ ...................................... 764

Mammalia ............................... 494

Mammals.................................. 494

Mantidø ................................... 667

mandtii, Cepphus......................... 634

Mandt's Guillemot ....................... 634

Mangrove Snapper...................... 734

Manta ...................................... 667

Manx Shearwater........................ 623

Many-spined Stickleback............... 704

Map Turtle.............................. 638

Mareca ........................................ 612

margaratis, Enneacanthus.............. 725

margaritus, Squalus.................... 681

marginatum, Ophidium.................... 756

marila, var. nearctica, Aythya......... 615

marinus, Flurichthys.................. 673

Larus .......................... 626

Petromyzon .................. 658

Sebastes .......................... 748

Tylosurus ..................... 699

maritima, Tringa........................ 591

maritimus, Ammodramus............... 542

Corvus .......................... 530

Marlin ...................................... 593

marmoratus, Antennarius............... 764

Marmot.................................... 502 
Marsh Harrier.......................... 574

Hawk ........................... 574

Hen.................................. 601

Robin............................ 545

Tern ............................ 628

Marsipobranchii ........................... 657

Marsupialia.............................. 517

martinica, Ionornis.................... 603

Maryland Yellow Throat............... 562

massachusettensis, Canthorinus....... 767

Monacanthus .... 766

Masked Duck.............................. 619

mattowacca, Clupea...................... 684

maxima, Sterna.......................... 628

maximus, Cetorhinus.................... 663

Mayfish.,................................ 693

Meadow Lark............................. 533

Mouse.......................... 505

Mice (referred to)............. 510

mediterranea, Sarda.................... 713

Mediterranean Sea Horse............... 702

mediocris, Clupea......................... 684

Megalops.................................. 683

Megascops................................ 581

Melanerpes ................................. 520

Melanetta ................................ 618

melanocorys, Calamospiza.............. 547

melanogaster, Pleuronectes............. 761

Melanogrammus ........................ 757

melanolencus, Pityophis............... 645

Totanus................. 594

melanosticta, Salamandra.............. 654

Melanura.................................. 695

melas, Ameiurus......................... 671

Globicephalus .................... 517

Melergris ... ................................... 586

meleagris, Numida (referred to)....... 586

moloda, Agialitia ........................ 599

melodia, Melospiza...................... 544

Melospiza .................................... 544

Menhaden ................................ 686

Menidia.................................. 707

Menticirrhus ................................ 741

mephitica, Mephitis .................... 511

Mephitis................................... 511

Merganser................................. 609

merganser, Mergus........................ 609

Mergulus ................................... 636

mergus, Merganser.......................... 609

meridionalis, Procellaria.................. 623

Merlangus .............................. 758

Merlucius .................................. 759

Merula .......................................... 572

mesogaster, Parezocottas................ 700

Mesognistius ............................. 726

Mesoprion ................................ 734

mesotrema, Asternotremia.............. 723

metis, Delphinus, see Tursiops tursio.

Metoponops............................... 760

mexicanus, Himantopus................. 588
Mice ....................................... 504

Micristius .................................... 694

Microgadus............................... 758

Micropalama ........................... 590

Microperca ................................ 730

Micropodidæ .............................. 524

Micropogon ................................. 740

Micropterns............................... 727

Microptergx............................... 717

Microsorex ................................... 497

microstomus, Citharichthys............ 760

Etropas ................... 760

migratoria, Merula..................... 572

migratoriug, Ectopistes.................. 583 var. of Sciurus niger.... 500

milberti, Arius............................6 673

Eulamia............................6 660

Milk Snake.............................. 647

Miller's Thumb................................ 749

Milvulus.................................... 525

Mimus......................................... 564

miniatus, Diemyctylus.................. 653 var. of Diemyetylus viridescens...................... 653

minimue, Empidonax..................... 528

Minnilus ..........................676, 678

minor, var. of Lozia curvirostra...... 537

Philohela ........................ 589

Minnow .......................677, 693, 694

Minnows ...........................676, 692

Mink ...................................... 510

minutilla, Tringa........................ 592

mitchilli, Acanthocottus................ 750

Engraulis...................... 688

Stolephorus...................... 688

mitrata, Sylvania......................... 563

Minytrema ................................. 675

Mniotiltidæ ................................ 554

Mniotilta ................................... 554

Mocking Bird.............................. 564

Moharras... ................................. 742

Mola........................................... 770

mola, Orthagoriscus....................... 770

Molacanthus................................... 769

Moles.......................................... 498

Mole Shrew................................... 496

mollis, Achirus ............................ 763

mollissima, Somateria..................... 617

Molothrus ....................................... 531

Monacanthus ................................... 766

monax, Arctomys........................ 502

Monkfish .................................... 763

monopterygius, Aspidophoroides...... 750

montícola, Spizella......................... 543

Moonfigh........................................ 716

mordax, Osmerus........................... 689

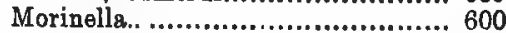

morio, Epinephelus...................733, 734

Morone......................................... 732

Morrhua ................................... 758 
morrhua, Gadus..................... 758

Mossbunker............................... 686

motacilla, Seiurus...................... 561

Motacillidæ ............................. 564

Motella ................................... 756

Mother of Eels............................ 755

Mourning Dove........................... 583

Warbler .................... 562

Mouse....................................... 504

Mougefish................................... 764

Moxostoma................................. 675

mucronata, Perca ....................... 732

mucronatum, Ophidium................ 754

Mud Dab................................. 762

Dace............................... 695

Mudfish.................................... 695

Mud Hen (Fulica americana):......... 604 (Rallus longirostris)......... 601 (referred to).................. 509

Minnow............................. 695

Minnows ........................... 695

Perch ................................ 723

Sucker ............................. 674

Sunfish .......................724, 725

Turtle ......................638, 639

Muffle-jaw .............................. 749

Mugil..............................706, 740

Mugillidæ ............................... 706

muhlenbergii, Chelopus.................. 637

Muhlenberg's Tortoise.................. 637

Mutica, Amyda......................... 641

Mullet ..................................... 675

Mullets.................................... 706

multifasciata, Hydrargyra............. 693

Mummichog .......................692, 693

Mupus ................................... 721

Muræna................................697, 698

Murænoides.............................. 754

Murre..................................... 635

Muridæ ................................... 504

Mus ..................................... 504

Museum Specimens..................... 492

musculus, Mus......................... 504

Muskrat.................................. 506

Musk Turtle............................ 640

Mustela ................................509, 510

Mustelids................................. 509

mustelinus, Turdus....................... 570

Mustelus ................................. 660

Mutton fish .............................. 755

Myiarchus ........................... 526

Myiodioctes................................ 563

Myliobatidæ ............................. 666

Myliobatis.............................. 666

Myrtle Warbler........................... 557

Mysticete................................ 514

mysticetes, Balæna ...................... 514

Myxine .................................. 657

Myxinidx................................. 657

'Myzopsetta.............................. 762
N.

nøvia, Hesperocichla................... 572 næviuf, var. of Nycticorax nycticorax ........................ 609

Seiurus .. ..................... 561

Nanemys ................................ 638

Nashville Warbler....................... 555

nasutus, Argyreus...................... 678

Leuciseus .................... 678

Natalia, var. cupreus, Amiurus........ 672

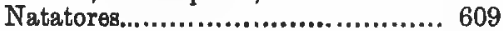

Nauclerus ................................. 718

Naucrates .............................. 718

naucrates, Echeneis..................708, 709

nearctica, var. of Aythya marila...... 615

nebrascensis, Nocomis .................. 679

nebulosum, Syrnium................... 580

nebulosus, Ameiurus.................... 671

Menticirrhus .............. 741

Necturus ................................ 656

Needle-fish ................................ 699

Nelson's Sparrow........................ 541

nelsoni, var. of Ammodramus cauda.

cutus .............................. 541

Nematognathi............................ 670

Neomænis................................ 734

Neotoma ................................ 505

Nettion ................................... 611

Newte................................... 652

New York Stickleback................. 705

Nibbler .................................. 743

niger, Conger............................... 698

Esox............................6 695

Gasterosteus.. .................... 705

Sciurus............................. 500

var. of Sciurus niger............ 501

Night Hawk........................... 523 Jar.............................. 523

nigra, Desmognathus.................... 653

Elacate ......................... 710

Rhynchops ......................6 631 var surinamensis, Hydrochelidon ......................... 630

nigrescens, Serranus................... 733

nigricans, Acanthurus,................. 745

Branta ....................... 620

Catostomus................. 674

Huro ........................ 727

var. of Potromyzon marinus .......................6.658 65

nigricollis, Colymbus..................... 632

Himantopus ............. 588

nigrofasciatus, Fundulus................ 693 var. of Fundulus het. oroclitus .............663

nigromacalatus, Pomoxys.............. 724

nilotica. Gelochelidon.................... 628

Nine-spined Stickleback............... 704

Nisus................................., 574 
nivalis, var. of Chen hyperborea......619

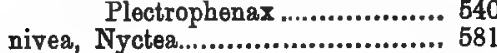

Nocomis ................................. 679

noctivagang, Vespertilio.................. 495

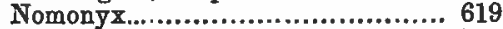

Northern Black Sea Bass.............. 733

Hare ...........................5 507

Phalarope..................... 587

Pickerel ........................6 696

Rattlesnake.................... 648

Raven ....................... 529

Scup ......................., 737

Shrike (referred to) ......... 540

Wax-wing ..................... 550

notata, Menidia.......................... 707

notatus, Hyborhynchus ................. 676

Notemigonus............................. 681

Notophthalmus ......................... 652

Notropis.................................677 678

Notarus...................................... 671

norvegicus, Perca........................ 748

Norway Rat.................................. 504

noveboracensis, A talapha............... 494

Exocœtus ............. 701

Gasterosteus ........... 705

Naucrates .............. 718

Porzana............... 602

Putorius................ 510

Seiurus.................. 561

Vireo................... 553

novemlineatus, Chasmodes ............. 754

nuchalis, Hybognathus.................. 676

Nambfish .................................. 664

Numenius .............................. 597

Numida, meleagris (referred to) ........ 586

nummularis, Molaranthus.............. 769

Nuthateh ................................... 568

nuttallii, Oppselurus........................ 701

Nyctala ..................................: 580

Nyctea ................................... 581

nyctea, Nyctea............................ 581

Nyetiardæ gardeni....................... 609

Nycticorax ............................6.609 609

nycticorax, var. nævius, Nycticorax.. 609

o.

obesus, Ennercanthus.................. 725

obscura, Anas.............................. 611

obscurus, Carcharias........................ 661

Centrarchus .................... 728

obliquus, Liostomas..................... 740

Oblong Flounder.......................... 761

oblonga, Platessa, Pleuronectes........ 761

oblongum, Moxostoma................... 675

oblongus, Paralichthys.................... 761

obeoletus, Coluber........................ 645

occidentalis, Conger....................... 698 occidentalis, Erennetes ................. 593.

Gasterosteus ............... 704

Monacanthis .............. 766

Noturus.................... 671

Scombroides ............... 719

Torpedo .................... 664

occipitomaculats, Storeria.............. 644

oceanica, Isognatha....................... 698

Oceanic Catfish.......................... 673

oceanites ..................................... 624

ocoanodroma ................................. 624

oceanus, Oceanites....................... 624

ocellaris, Chænopsetta................... 761

Paralichthys .................. 761

ocellata, Raia.............................. 664

Scimna ........................... 740

ocellatus, Platophrys...................... 761

ochrophcea, Desmognathus.............. 653

octodecimspinosas, Cott as............... 749

Odontaspidæ ................................ 662

Odontaspis .................................... 662

Odontocete .............................. 515

odoratus, Aromochelys.................... 640

ogak, Gadns............................... 758

oglinum, Opisthonema.................. 686

Oidemia ................................... 618

Old Squaw.................................. 616

Oldwife................................616, 740

Oligocephalus ............................... 729

Oligoplites................................. 719

olivaceas, Vireo............................ 552

Olive-backed Thrash..................... 571

Olive-sided Flycatcher.................. 527.

olmstedi, Boleosoma...................... 728

Olor.......................................... 620

Oncorhynchus........................... 690

oneida, Ptychostomus.................... 675

onitis, Hiatula............................... 743

Onas ............................................... 756

opaca, A mblystoma....................... 655

Opaque Salamander..................... 655

Opheodrys ................................ 646

Ophibolus ................................... 647

Ophidia.......................................... 643

Ophidiidæ.................................... 756

Ophidinm .................................754, 756

ophryas, Paralichthys................... 761

Opisthonema ................................. 686

Oporornis ....................................... 561

Opossum .................................. 517

Orange-crowned Warbler.................. 555

Orange-throated Warbler.................. 559

Orbidus ........................................ 768

Orca............................................ 517

orca, Orca................................... 517

Orchard Oriole............................. 534

ordii, Ibis.................................... 605

ordinata, var, of Entænia sirtalis...... 645

Oregon Robin.............................. 572

ornatus, Esor............................. 695 
Ornichthys ................................. 751

Orthagoriscidm................................. 769

Orthagoriscus .............................. 770

Orthopistis................................ 735

Orthopsetta ............................... 760

orientalis, Oncorhynchus................. 690

Orioles ....................................... 531

Ortolan ..................................... 602

Ortyx ..................................... 584

Oryenus ................................. 714

oryzivorue, Dolichonyx................. 531

osmerinus, Hybognathus ..................6 676

Osmerus ..................................689

Osprey (referred to) ..................... 577

ossens, Lepidosteus.......................... 669

ossifragus, Corvus........................ 530

osteochir, Kombochirus................... 709

Ostraciidæ..................................... 765

Ostracium ..................................... 765

Oswego Bass................................ 727

Otocoris ..................................... 528

Otolithus .................................... 741

Otter........................................ 510

ovatus, Trachynotus...................... 718

Oven Bird................................. 560

ovicephalue, Sargas..................... 738

ovinus, Lebias............................... 692

ovis, Sargus................................. 738

Owl ........................................ 579

Orbird .................................... 592

Ox-eye .................................... 598

Oxyrhina.................................663 663

oxyrhynchus, var. of Acipenser sturio ................................... 668

oxypterus, Epinephelas.................. 733

oxy uris, Lepidostend..................... 669

Oyster-catchers...........................6.60 600

Oyster-fisb................................743, 753

Ozotheca................................... 640

P.

pacifica, var, of Tringa alpina......... 592

pacificus, Argyreiosas..................... 716

Pagrus...................................... 736

Painted Turtle............................ 638

Palinurichthys ........................... 721

Palinurus ................................. 721

pallasi, Molacanthus..................... 769 var. of Turdus aonalaschkæ... 571

palliatus, Hæmatopus...................6 600

pallida, Lepomis........................... 727

palmarum, Dendroica................... 560 var. hypochrysea, Dendroica..................... 560

palmipes, Prionotas....................... 757

Palm Warbler................................ 560

Paludicolæ ................................. 601

palustris, Cistothorus................... 567 palustris, Hesperomys................ 505

Malacoclemmys............... 639

Melospiza ................... 544

Rana.............................. 649

Pammelas.................................. 721

pampanus, Bothrolmmus............... 718

Pandion ................................ 578

Panther (referred to).................... 513

paradisæa, Sterna....................629, 630

Paralichty

Paranthias .................................. 733

Parasitic Jaeger........................... 625

parasiticus, Simenchelys ................. 696

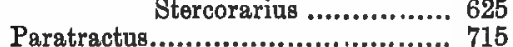

pardalis, Monacanthis................... 767

Parephippus ............................. 744

Parexoccetus................................ 700

Paridm ...................................... 568

Partridge...............................584, 585

Parula ....................................... 556

Parula Warbler............................ 556

Parus.. ....................................... 569

paru, Stromateus......................... 720

parva, Blarina........................... 497

Lucania .......................... 694

Pagsenger Pigeon....................... 583

Passerella ....................................... 545

Passer..................................... 539

passerculus, Ammodranus.............. 541

Passeres ..................................... 525

Passerina ..................................... 546

passerinus, var. of Ammodramus savannarum .................. 541

Coturniculus................... 541

Pavo cristatus (referred to).............. 586

Pavoncella................................. 595

Peabody Bird.............................. 543

Peacock (referred to) ..................... 586

Pearly Dace................................ 681

peckianus, Syngnathus................... 702

Pectoral Sandpiper........................ 591

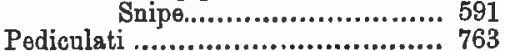

Peop .....................................592, 593

Pee-wee................................... 527

Peo-wit .......................................... 527

Pegador ...................................... 708

pelagica, Chætura........................ 524

Pelamys .................................. 713

Pelecanidæ .................................. 622

Pelecanus .................................... 622

Pelicans ................................... 622

Pelionetta....................................... 618

penelope, Anas......................... 612

pennantii, Mustela.......................... 509

penneylvaniea, Dendroica............... 558

pennsylvanicum, Cinosternum.......... 639

penngylvanicus, Anthus................. 564 
pennsylvanicus, Arvicola,.............. 505

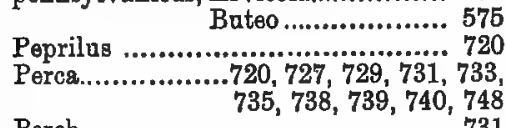

Perch

Perches ........................................ 728

Perching Birds............................ 525

Percidø.............................728, 731

perciformis, Lirus....................... 721

Percina ..................................... 729

Percopsidm ................................. 691

Percopsis.................................. 691

peregrina, Helminthophila............ 555

Peregrine Falcon......................... 577

peregrinus, var. anatum, Falco....... 577

perfasciatus, Stolephorus............... 688

Perissoglosea ............................... 556

personatus, Sorex......................... 497

perspicillats, Oidemia.................... 618

perspicillatus, Lagenorhynchas........ 516

perspicuus, Hyborhynchus.............66 676

Petrels.................................623, 624

Petrochelidon................................. 549

Petromjzontidæ ............................. 657

petrosus, Magil............................ 706

Phalacrocorax............................. 621

Phalacrocoracidø .......................... 621

Phalaropes ................................ 587

Phalaropodidø .......................... 587

Phalaropus .................................. 587

Phasianidæ............................ 586

Phasianus colchicus (referred to)..... 586

Pheasant (referred to, 586)............ 585

phenax, Lepomis ........................ 726

philadelphia, Geothlypis ................ 562

Larue ......................6.627

Philadelphia Greenlet................... 552

Vireo ........................ 552

Warbler.................... 552

philadelphicus, Vireo...................... 552

Philohela .................................. 589

phlebotomus, Acanthorus................ 745

Phoca ...................................... 508

Phocæna ................................. 515

phocæna, Phocæna.......................... 516

Phocidæ ................................ 508

Phobe ..................................... 527

phoobe, Sayornis.......................... 527

phoenicens, Agelaius.................... 532

Pholis ....................................... 754

Photogensis (or Photogenis)............ 677

Phoxinus ................................. 681

Phycis .................................... 756

Phyllophilophis ........................... 646

Physeter macrocephalus (referred to), 514

Physoclisti ................................ 699

Physostomi............................... 670

Pici. ............................................ 518

Picidæ ....................................... 518
Pickerel.............................695, 696

Pickerel Frog............................. 649

pickeringii, Hyla........................651 65

Pickering's Tree-toad................... 651

picta, Chrysemys.......................... 638

Picns ......................................... 518

Pied Shelldrake........................ 610

Pied-billed Grebe.......................... 632

Pigeon Hawk........................574, 578

Pigeons .................................. 583

Pike (referred to, 523)........695, 696, 731

pilatus, Prionotus........................ 751

Pileated Woodpecker..................... 520

pileatus, Ceophloous........................ 520

Pileoma...................................... 729

pilosus, Diodon.......................... 768

Trichodiodon.................... 768

Pilot ....................................... 721

Pilot-fishes.................................. 714

Pilot-fish ............................517, 718

Pilot Snake................................. 645

Pimelepterus ............................. 738

Pimephales.................................. 676

Pimolodus................................. 671

Pimelodus coerulescens.................. 672

Pinicola ................................... 537

Pine-creeping Warbler.................... 559

Pine Finch................................ 539

Linnet................................... 539

Mouse................................. 506

Sigkin................................. 539

Snake ............................... 645

Warbler .............................. 559

pinetorum, Arvicola....................... 506

Pine-tree Lizard......................... 641

Pinfish ..................................... 737

piniger, Enneacanthus..................... 725

Pintado ...................................... 713

Pin-tail ..................................... 613

pinus, Dendroica........................... 559

Helminthophila.................... 555

Spinas .............................. 539

pipiens, Rana .......................... 650

Piping Plover .............................. 599

Pipefishes............................... 702

Pipefish ..................................... 703

Pipilo ...................................... 545

Piranga ................................... 547

Pirate Perches............................. 722

Perch.............................. 723

Pisces........................................ 657

piscatorius, Lophius.................... 763

pisculentus, Esox, Fundulus............ 693

pisquetus, Caranx......................... 715

Pityophis................................ 645

plagiodon, Prodelphinus................ 515

Plagiostomi ................................ 659

Plaice ...................................... 762

Plargyrus .................................. 678

Platessa ............................. 761,762 
platessoides, Hippoglossoides......

Platophrys ................................. 761

platycephalus, Noturus.................. 671

Platypodon................................... 660

platyrhinus, Hoterodon................. 643

Sorex ..................... 497

platystomus, Lepidosteus.................. 670

Plautus impennis (referred to).......... 636

Plectognathi ............................... 765

Plectospondyli............................ 673

Plectrophenax............................ 540

Plegadis................................... 605

Plestiodon ............................... 642

Plestiodon striatus ...................... 642

Plethodon................................... 654

Plethodontidæ.............................. 654

Plethostigma ............................. 761

Pleurodelidæx............................. 652

Plenronectes ....................760, 761, 763

Pleuronectidæs ........................... 759

Plover ..........................593, 596, 598

Plovers .................................... 597

plumbea, Hydrochelidon............... 630

plumieri, Diabasis........................ 735

Mugil ........................... 706

pneumatophorus, Scomber............. 712

Pochard......................................., 614

Podiceps.......................................... 631

Podiceps cornutus.......................6 631

griseigena..................... 632

podiceps, Podilymbus .................... 632

Podicipidø................................ 631

Podilymbus ................................ 632

Posilichthys............................... 729

Pogonias ................................. 739

Poisonous Snake8........................ 648

Pollachius.................................. 758

Pollack ....................................... 758

Polioptila.................................. 570

polyglottus, Mimus ..................... 564

Pomacanthus .............................. 745

Pomadyв ....................................... 735

pomarinus, Stercorarius ..................6 625

Pomarine Jaeger ......................... 625

Pomatomidx .............................. 720

Pomatomus................................. 720

Pomatopsetta ............................. 761

pomatorhinus, Stercorarius ............ 625

Pomobolus .................................. 684

Pompano ................................. 718

Pomotis .....................725, 726, 727

pomotis, Acantharchus................. 725

Pomoxis ................................... 724

Pond Broad-bill............................ 615

Saw-bill $\ldots . . . . . . . . . . . . . . . . . . . . .6610$

Turtles.............................6 637

Poocætes ................................ 542

Popetue...................................... 523

Porbeagles.................................. 662

Porbeagle................................. 663
Porcupine ............................. 507

Porgee ..............................737, 744

porosus, var. of Esox americanus .... 696

Poronotus ................................ 720

porphyriticus, Gyrinophilus............ 655

Porpoises .................................... 515

portlandica, Sterna....................., 630

Porzana...................................... 602

Potomac Channel Catfish................ 672

præstabilis, Alosa........................ 685

Prairie Ohicken............................. 585

Hen............................. 585

Warbler........................... 560

pratincola, Strix ........................ 579

Prickly Ray................................ 665

princeps, Ammodramus................ 541

principalis, var. of Corvus corax...... 529

Prionodon ..........................660, 661

Prionotus................................. 751

Pristipoma.............................. 735

probatocephalus, Diplodus .............. 738

Procellaria meridionalis................ 623

pelagica (referred to)..... 624

Procellariidæ ............................... 623

procne, Cliola................................ 677

Procyon ...................................... 512

Procyonidæx............................. 512

Prodelphinus ............................... 515

Progne .................................... 549

Proteida .................................. 656

protopteræ................................... 670

pruinosa, Morrhua ......................... 758

pruinosus, Vespertilio ................... 495

Psettichthys ............................. 761

Pseudemys ................................. 639

pseudoharengus, Clupea................. 684

Psendopleuronectes..................... 762

Pseudorhombus ............................. 761

Preudotriton.................................. 655

Pteromys.................................. 501

Pterophryne.............................. 764

Pterophrynoides ... ......................... 764

Ptychemys................................. 639

Ptychostomus............................... 675

pubescens, Dryobates....................... 519

Puffers .................................... 768

Puffinus ....................................... 623

puffinus, Puffinus........................ 623

pugnax, Pavoncella..................... 595

Pug-nosed Eel ............................... 698

pulchellus, Chilonemus .................. 680

pallus, Monacanthus.................... 767

Pumpkin Seed........................... 727

punctata, Lamna......................... 663

Sciæna, Perca................. 739

punctatum, Amblystoma............... 656

punctatus, Decapterus................... 743

Diadophis .................... 646

Ictalurus.....................6.672

Phycis....................... 756 
punctulata, Microperca................. 730

punctulatus, Calliurus.................... 728

Lampugus ................ 722

pungitius, Gasterosteus.................. 704

Purple Finch ............................ 537

Gallinule........................... 603

Grackle (referred to, 540).... 535

Martin ........................... 549

Salamander........................ 655

Sandpiper ..................... 591

purpurea, Progne ......................... 549

purpureus, Carpodacus................. 537

Merlangus.................. 758
pusilla, Spizella....................... 543

Sylvania ......................... 563

pusillas, Ereunetes....................... 593 var, traillii, Empidonax...... 527

putnami, Euchalarodus................. 762

Putorius ................................... 510

pygmæa, Umbra ....................... 695 var. of Esox americanus... 696

Pygopodes ................................ 631

Pygosteus ................................ 704

Q.

Qua Bird................................ 609

quadracus, Apeltes... ...................... 705

Gasterosteus ................ 705

quadratus, Zeus .......................... 744

quadricorne, Ostracium.................. 765

quadrilineatum, Hæmulon.............. 736

quadriloba, Rhinoptera................... 666

Quail........................................ 584

Querquedula .............................. 611

quiescens, Uranidea ....................... 749

Quill-back ............................... 674

guinnat, Salmo.............................6 690

Quiscalus .................................. 535

Quiscalus quiscula (referred-to)....... 540

quiscula, var. æneus, Quiscalus ........ 536

Quok Quiscalus (referred to, 540).. 535

R.

Rabbit-fish .............................. 769

Rabbits...................................... 507

Racer......................................... 645

Raccoon, ................................. 512

radiata, Raiz ............................ 665

Raft-duck ................................... 615

Raia....................................... 664

Raiæ ...................................... 663

Raiidw.................................... 664

Rails ....................................601, 602

Rainbow Darter.......................... 729

Rainwater-fish ............................. 694

Rajides.......................................... 663

Rallus ....................................... 601
Rallidæ ................................6 601

Rallus crepitans (referred to) .......... 509

elegans (referred to)............ 601

Rana ........................................... 649

Raptores ...................................... 573

Rasores .................................... 584

Rattleenake .............................. 648

rattus, Mas................................ 504

Raven ...................................... 529

Rays ....................................... 664

Razor-billed Aak........................ 635

Recurvirostra............................. 588

Recurvirostridæ ........................... 588

'Red-backed Salamander................. 654

Sandpiper ................. 592

Red Bass.................................. 740

Bat...................................... 494

Red-bellied Dace........................ 676

Nuthatch ................... 569

Snake........................ 644

Terrapin .................... 639

Woodpecker ............... 521

Redbird.................................... 545

Red-breasted Merganser .............. 610

Nuthatch................. 569

Sandpiper................. 591

Snipe....................... 590

Red-cockaded Woodpecker............. 519

Red Crossbill............................... 537

Deer .................................. 513

Eft .................................. 653

Evet.. .................................... 653

Red-eye......................................... 724

Red-eyed Flycatcher...................... 552

Vireo........................... 552

Red-fin Shiner........................... 678

Redfish .............................740, 748

Red For.................................... 508

Grouper ................................ 734

Red-head ................................... 614

Red-headed Woodpecker ............... 520

Red Horse..............................675, 740

Red-month ............................... 735

Red-neck Duck............................ 615

Red-necked Grebe ......................... 632

Red Phalarope............................. 588

Sea Perch ............................... 748

Red-shouldered Buzzard................. 576

Hawk................ 578

Red-sided Darter......................... 730

Red Snake................................. 647

Squirrel ............................... 501

Red-tailed Buzzard....................... 575

Hawk.......................... 575

Red-throated Diver........................ 633

Loon........................6 633

Red Triton ................................ 655

Red-winged Blackbird.................. 532

Starling..................... 532 


\section{INDEX.}

Red-wings ............................... 533

Reedbird ................................... 531

Reeve ...................................... 595

regalis, Cynoscion......................... 741

Phycis.............................. 756

regius, Hybognathus.....................6 676

Phycis............................... 756

Thalasseus........................ 628

Regulus .................................. 569

remora, Echeneis.......................... 709

Remoras ................................708, 709

Reniceps .................................. 661

Reptilia..................................... 637

Reptiles .................................. 492

reticulatus, Esox......................... 696

Rhinichthyв ............................6 678

Khinonemus............................... 756

Rhinoptera .............................666 666

Rhomboidal Porgee....................... 737

rhomboides, Lagodon.................... 737

Trachynotus................7.78 718

Rhombus.......................720, 721, 760

rhotheus, Semotilus...................... 680

Rhynchopidø............................. 631

Rhynchops .............................. 631

Riband Snake.............................6 645

Ribbon-figh ................................. 711

Ricebird................................... 531

Rice-field Mouse......................... 505

richardsoni, var. meridionalis, Ura-

nidea ..................................... 749

Ridgway, Robert........................... 490

Right Whale.............................. 514

Ring-billed Gull............................ 627

Ringed Perch............................. 731

Ring-necked Duck........................ 615

Snake ..................... 646

Ring-neck Plover......................... 599

Ring-tailed Eagle....................... 577

Marlin...................... 594

ringvia, Uria............................... 635

Riparia ..................................... 550

riparia, Arvicola........................... 505

Clivicola............................ 550

Risea.. ....................................... 626

River Chub................................6 679

Roach ...................................680, 681

Robin..................................... 572

Robin Snipe............................... 591

robustus, Ptychostomus.................. 675

Roceus...................................... 732

rochei, Auxis............................. 712

kockfigh .......................693, 729, 732

Rockfishes ................................ 747

Rockling...................................... 756

Rock Mullet............................... 706

Rodentia .................................. 499

Romero .................................... 718

rondeletii, Exoccetus..................... 700

Rorqualis rostratus (referred to)...... 514
Rorquals (referred to).................. 514

Rorqualus borealis (referred to)....... 514

Roseate Tern.............................. 630

Rose-breasted Grosbeak................... 546

Rose-colored Chub.......................... 680

Rosefish................................. 748

rostrata, var. of Acanthis linaria..... 538 Anguilla ....................... 697

Platessa .......................... 762

Rostrated Dory.....................716, 717

rostratus, Rorqualus (referred to).... 514

Rosy Dace................................... 681

rotunda, Mola.................................. 770

Round Herring.............................. 684

Round Robin............................. 714

Rough-winged Swallow................. 550

Rough Dab..................................... 761

Rough-head Shiner......................... 678

Royal Tern................................ 628

rubicauda, Ichthelis........................ 726

Pomotis......................... 726

rubida, Erismatura........................ 619

ruber, Spelerpes............................. 655

rubra, Piranga..........................547, 548

Ruby.throated Humming Bird........ 524

Ruby-crowned Kinglet................... 570

Rudder-fish .................................. 719707920,721

Ruddy Duck............................... 619

Plover.................................. 593

Ruff ........................................... 595

Ruffed Grouse................................ 585

rufescens, Tryngiteg.................... 596

ruficapilla, Helminthophila........... 555

ruficollis, var. of Ardea tricolor....... 608

rufue, Harporhynchus................... 565

Labrax ................................. 732

LPnx .................................. 508

rugaвz, Pseudemув......................... 639

Ruminantia............................. 513

rupestris, Amboplites...................... 724

rusticola, Scolopaz........................ 589

Rusty Blackbird............................ 534

Rusty-crowned Falcon.................... 578

ruticilla, Sotophaga....................... 564

rutilus, Erotomys......................... 505

\section{s.}

Sabine's Gull.............................. 628

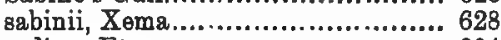

sadina, Etrumeus............................ 684

Saddle-back Gull......................... 626

Sailfieh .................................... 674

Sailor's Choice.............................. 735

Salamanders .....................652, 653-656

Salamandridæ............................ 652

salar, Salmo .................................... 690

Salientia ..................................... 649 
Salmo salmoides, Grystes......................... 728

Micropterus................. 727

Salmon.................................... 690

salmonea, Perca.......................... 731

Spelerpes...................... 655

Salmonidæ................................. 689

saltatrix, Pomatomus.................. 720

Salt-margh Turtle.......................... 639

Salt-water Marsh Hen................. 601

Minnow....................... 693

Terrapin......................... 639

Turtles......................... 640

sancti-johannis, var. of Archibuteo

lagopus.

Sand Dab................................... 762

Eel.................................... 708

Sanderling....................................... 593

Sand Flounder............................. 760

Lannces ............................... 708

Martin ............................... 550

San Domingo Duck....................... 619

Sand Pike................................. 689

Sandpipere................................... 591

Sand Porgee................................ 737

Sharks.............................. 662

Sand-shoal Duck.......................... 617

sandvicensis, var. acuflavidus, Sterna, 629

sandwicheneis, var. 8avanna, Ammo-

dramus

Sandwich Tern............................... 629

Sandy Mocking Bird.................... 565

sapidissima, Alosa....................... 585

Clupea ..................... 685

Sapsucker ................................... 568

Sap-sucking Woodpeckers............... 519

Sarda............................................ 713

sarda, Sarda ............................. 713

Sargas..................................737, 738

Sarpo..................................... 753

sarritor, Prionotas.... .................... 751

satrapa, Regulus.......................... 569

Sauril ...................................... 641

saurita, Eutænia.......................... 645

Saurug ..................................... 689

saurus, Elops............................. 683

Oligoplites ...................... 719

Scomberesox....................... 700

Saury ........................................ 700

savanna, yar. of Ammodramus sand.

wichensis

Savannah Cricket....................... 541

Savanna Sparrow........................... 541

savannarum, var, passerinus, Ammo-

dramus

Saw-whet Owl................................ 58 54

saxatilis, Menticirrhus................... 741

sayi, Trygon............................... 666

sayanus, Aphredoderus..................... 723

Sayornis.
Sayris.,.................................. 700

Scabbard-fish ............................ 711

Scad........................................... 714

Scalops.................................... 498

вcandiaca, Nyctea..................... 581

Scansores .................................. 518

Scapanus .................................. 498

Scaphiopidæ ............................ 650

Scaphiopus .................................6.650

Scarlet Tanager.......................... 547

Sceloporus ................................6.641

schospfi, Alatera......................... 767

Schuylkill Catfish....................... 671

Sciæna ..............................729, 739

Sciænidæ................................ 738

Sciænops...................................... 740

Scincid $\circledast$................................ 642

Sciseor-tailed Flycatcher................. 526

Sciuridx .................................. 499

Sciurus .................................. 500

Sciuropterus ................................. 501

Scolecophagus ............................ 534

Scoliodon .................................... 661

scolopacens, Macrorhampus............ 590

Scolopacidæ................................. 589

Scolopax .................................. 589

Scolopsis ................................... 723

Scomber .......................712, 716, 719

Scomberesox................................ 700

Scomberomorus ....................... 713

Scomberosocidø ......................... 699

Scombridæ................................... 712

Scombroides ................................ 719

scombrus, Scomber....................... 712

Scopelidm.................................. 688

Scorpæna ................................. 748

Scorpænidæ .................................... 747

Scoters..................................... 618

Scotiapex ............................... 580

Scotophilus.................................. 495

Scotophis...................................... 645

Screech Owl.............................. 581

scripta, Alutera............................ 767

Sculpin ................................. 749, 750

Scuppaug ................................. 737

scutatum, Hemidactylium............... 654

scutellatum, Scomberesox............... 700

Sea Bass.................................... 731

Catfish........................................ 673

Coot....................................... 618

Devils....................................... 667

Hog .................................. 515

Horses................................... 702

Seals ............................................ 508

Sea Porpoise................................. 515

Raven ..................................... 748

Robin .................................. 751

Sea side Finch................................. 542

Sparrow............................. 542

Sea Swallow................................... 629 
sebago, Salmo............................ 690

Sebastes ................................. 748

sectatrix, Perca............................. 738

secundo-dorsalis, Thynnus.............. 714

Seiurus ........................................ 560

Selachii ..................................... 659

Selachus.......................................... 663

Selene ..................................716, 717

semifasciatum, Pileoma................. 729

semipalmata, Eg gialitis................... 599

Symphemia............... 695

Semipalmated Plover ..................... 599

Sandpiper ............... 593

Tattler ................... 595

Semotilus ...................................... 679

septentrionalis, Urinator ................. 633

Sergeant-figh ........................... 710

Seriola ................................717, 718

eerotinus, Vesperugo..................... 495

eerpentina, Chilydra..................... 640

Serpents. .................................. 613

serrata, Fistularia ....................... 703

serrator, Merganser ....................... 610

Serranidæ .................................. 731

Serranus .................................... 733

Serripennis, Stelgidopteryz .......... 550

setifer, Monacanthus.................... 766

setipinnis, Selene...................... 717

Setophaga....................................... 564

Shad .......................................... 685

Shad Frog.................................... 649

Sharks....................................... 659

Sharp-nosed Shark....................... 661

Sharp-ghinned Hawk.................... 574

Sharp-tailed Finch........................ 5 51

Shearwaters (et seq.)......................6.623

Shearwater................................ 631

Sheepshead............................... 738

\$heopshead Gull.......................... 629

Shelldrake (et seq.)...................... 609

Shiner....................677, 678, 681, 717

Shitepoke................................ 608

Shoemaker................................ 716

Shore Birds............................... 587

Lark ............................. 528

Short-billed Marsh Wren................ 567

Short-eared Owl.......................... 580

Short-nosed Gar Pike..................... 670

Sturgeon....................... 668

Short-tailed Shrew......................... 496

Shrews .................... 497

Shovel-head Shark........................ 661

Shoveller ................................... 613

Shovel-nose .............................. 662

Shrews...........................491, 496, 497

Shrikes...................................... 551

Sialia........................................ 573

eialis, Noturus........................... 671

Sialia................................. 573

Sibbaldius tectirostris (referred to)... 514
Sickle.bill ............................... 597

Sierra ........................................ 713

Siluridø ....................................... 671

Silurus lividus.............................. 672

Silver-black Bat............................ 495

Silver Chub................................... 680

Eel..................................... 711

Silver-fin .........................677, 711

Silver Fox.................................. 508

Gar ................................ 699

Perch............................... 739

Silversides.............................706, 707

Silvery Carp Sucker..................... 674 Minnow .....................676, 67.7

Simenchelys ................................ 698

similis, var. of Fundulus majalis...... 693

simulans, Enneacanthus................ 725

Single-bearded Flying-fish.............. 701

sipedon, Tropidonotras................... 643

Siphostoma................................ 702

sirtalis, Eutænia........................ 644

Sitta ............................................ 568

Skates ....................................... 664

Skimmers..................................6.6.6. 631

Skim-brck ............................., 674

Skinks........................................ 642

Skipjack ...............................713, 720

Skipper .................................... 700

Skittle Dog................................. 659

Skuas ......................................... 625

Skunk .................................... 511

Skunk Porpoise........................... 516

Slate colored Junco........................ 544

Sleepmarken .............................. 657

Slender Herring............................. 684

Salamander ..................... 655

Small Blue Shark.......................... 660

Box Turtle .......................... 639

Dolphin ........................... 722

Green.crested Flycatcher....... 528

Smaller Spotted Salamander............ 656

Small-mouthed Black Bass.............. 728

Small Mud Turtle....................... 639

Small-scaled Sucker........................ 674

Smelt.......................................... 689

smithsonianus, var: of Larus argen-

tatus..................................6 626

Smooth Hound.......................... 660

Paffer ............................... 768

Snakes..................................... 643

Snapper.................................. 748

Snapping Tartles....................... 640

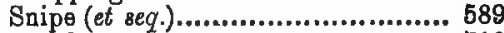

Snooks ................................... 710

Snow Bird................................... 544

Bunting ........................... 540

Snowflake............................. 540

Snow Goose................................ 619

Snowy Egret .............................. 608

Heron ........................... 608 
Snowy Owl ............................. 581

Snuffer .................................... 516

socialis, Spizella........................... 543

Social Whalo................................ 517

Soft-8helled Turtles.................640, 641

Soldier-fish ................................. 729

Sole .......................................... 763

Soler ....................................... 763

Solenostomus ............................. 703

solitarius, Scaphiopus................... 650

Totanas....................... 595

Vireo............................. 553

Solitary Greonlet......................... 553

Sandpiper ....................... 595

Spade-foot..................... 650

Tattler .......................... 595

Somateria.................................. 617

Song Sparrow.............................. 544

Sooty Shearwater........................... 624

Tern ............................... 630

Sora ......................................... 602

Sorex ...................................496, 497

soricidæ .................................. 496

Soriciscus ............................... 497

Soury ...................................... 689

Southern Garanx.......................... 716

Flounder ....................... 761

Porgee ............................. 736

Sting Ray..................... 666

Wax-wing ................... 551

South-8outherly............................ 616

Spade-foot Frogs........................ 650

Spanish Mackerel......................... 713

Spanish Mackerel of Europe.......... 712

Sparidæ.................................. 734

sparoides, Pomozis....................... 724

Sparrows ...........................539, 544

Sparrow Hawk (referred to)........... 540

Sparus..............727, 735, 736, 737, 738

sparverius, Falco (referred to, 540)... 578

Spatula .................................... 613

Spawn-eater ............................ 677

Spearfish...............................6674, 711

Spearfigh Remora ........................ 709

Specimens............................... 492

speciosus, Semotilus..................... 679

Speckle-bill Goose......................... 619

Speckled Tortoige......................... 638

Red-mouth..................... 735

Trout ............................ 691

spectabilis, Somateria.................. 617

Spelerper.................................... 654

Speotyto .................................... 582

Sperm Whale (referred to)............. 514

spet, Sphyræna.......................... 707

Sphyræna ................................... 707

Sphyrænidø.............................. 707

Sphyrapicas ............................ 518

Sphyrna.................................... 661

Sphyrniddø............................. 661
Spiked Dogfish......................... 659

spilopterus, Photogensis.................. 677

Spinacidær.................................... 659

spinarella, Gasterosteds................. 752

spinifer, Aspidonectes.................... 640

spinosus, Trachynotus................... 718

Spinus ...................................... 538

Spiny Dory................................ 718

Garnard.......................... 751

Spiny-rayed Fish......................... 705

Spiza ........................................ 547

Spizella ................................... 543

sponsa, Aix.................................. 614

Spoon-bill Dack.......................... 613

Spot........................................... 740

Spotted Adder............................. 647

Balloon-fish ................... 769

Caranx:............................. 714

Codling........................... 756

Dolphin ...................515, 722

Lampugus..................... 722

Mackerel ...................... 713

Mullet .....................675, 706

Sandpiper....................... 596

Spotted fin Shark......................... 661

Spotted-finned Sunfish ................ 725

Spotted Triton .............................. 652

Sea Trout........................ 741

Turbot .......................... 760

Turtle ............................. 638

Sprig-tail ...................................6 613

Spring Frog................................. 649

Minnow ......................... 693

Snake ................................. 646.

spurius, Icterus.............................. 534

Squali..................................... 659

squalipeta, Remora........................ 709

Squalius.................................... 681

Squalus..................659, 660, 662, 663

Squatarola ................................. 598

equatarola, Charadrius.................. 598

Squawk.................................... 609

Squeteague ................................. 741

squeteague, Labrus....................... 841

Squirrel-fish ............................... 735

Squirrel Hake.............................. 757

Squirrels ................................... 499

Stake Driver.............................. 605

Star-gazer .................................. 749

Star-gazers..................................... 746

Starling..................................... 532

Star-nosed Mole.......................... 498

Starry Ray ............................... 665

stearnsii, Seriola........................ 718

Stegani................................... 493

Steganopodes ............................. 521

Steganopus wilsoni....................... 587

Stelgidopteryx $\ldots . . . . . . . . . . . . . . . . . . . . . .550$

stellaris, Cistothorus....................... 567

Stenotomus............................... 736 
Stephanolepis............................ 766

Stercorariidø .................................... 625

Stercorarius................................... 625

Sterna .......................................... 628

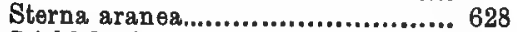

Sticklebacks..........................704, 705

Stiff-finned Remora..................... 709

stigmaticus, Ceratichthys............... 679

Stilbe.............................................. 681

Stilt ........................................ 588

Stilt Sandpiper.............................. 590

Stingaree .................................. 666

Sting Rays................................. 665

Stink-pots ..........................639, 640

. Stizostedium ................................ 731

Stolephoridø ............................... 688

Stolephorus ............................... 688

stomias, Trisotropis........................ 733

Stomodon................................. 759

.Ston $\theta$ Catfish.................................. 671

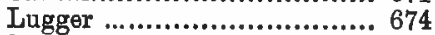

Roller ................................... 674

Snipe ................................... 594

Storeria..................................... 644

Storks ................................... 605

Stormy Petrel (referred to) ............ 624

Strawberry Bass.......................... 724

strepera, Anss.......................... 612

Strepsilas .................................. 600

striata, Dendroica ..................... 558

striatus, Plestiodon......................... 642

Serranus...........................7733

Tamias ......................500, 502

stricklandi, Puffinus........................ 624

strigatus, Prionotus...................... 751

Strigidm ................................ 579

Stripe-backed Salamander.............. 654

Striped Bass................................ 732

Mullet.................................. 706

Snake ............................. 644

Sucker ............................... 675

Strix......................................... 579

Stromateid $x$.............................. 720

Stromateus ............................... 720

Sturgeons.................................... 668

sturio, var, oxyrhynchus, Acipenser.. 668

Sturnella .................................. 533

subarquata, Ancylocheilus............... 592

subarcuatus. Cestracion..................6 66

subis, Progne............................. 549

subruficollis. Tryngites................... 596

subulatus, Vespertilio................... 495

subviolacea, Amblystoma................. 656

sucetta, Erimyzon........................6 675

Suckers ...............................673, 674

Sucking figh ................................. 709

sucklii, Squalus........................... 659

sueuri, Corypbæa a........................ 722

Sula .......................................... 621

Sulidæ ..................................... 621
Summer Dack............................. 614

Flounder ......................... 761

Green Snake...................... 646

Herring .......................... 685

Redbird .......................... 548

Tanager........................... 548

Warbler............................. 566

Sunfighes ............................................... 724

Sunfish .................................726, 770

superciliarie, Sterna....................... 630

superciliosa, Dendroica..................... 559

Surf Birds.....................................60 600

Duck ........................................ 618

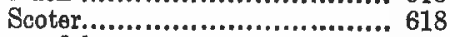

Surgeon fish .............................. 745

surinamensis, var, of Hydrochelidon nigra .................... 630

Lobotes ..................... 736

Surnia ........................................ 582

Surquehanna Salmon.................... 731

sutor, Caranx .............................. 716

swainsonii, var. of Turdus ustulatus.. 571

Swainson's Thrush.......................... 571

Swallows.................................. 549

Swallow.tailed Kite....................... 574

8wampinus, Fuadulus..................... 693

Swamp Blackbird.......................... 532

Owl............................... 580

Sparrow ............................ 544

Tres-frog.......................... 652

Swan.....................................620, 621

Swell Toad................................768, 769

Swifts (Birdg) ................................ 524

(Lizards) .............................. 641

Swift Garter Snaka.......................... 645

Swimming Birds............................ 609

Swingle-tail................................ 662

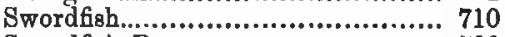

Swordfish Remora........................ 709

Sword Grampus............................ 517

Sylvania ................................. 563

gylvatica, Rana............................. 650

gylvaticus, Lepus......................... 507

Sylvias.. .................................... 669

Sylviida .................................... 569

Sylvicolidæ (referred to) .............. 537

Symphemia …............................ 595

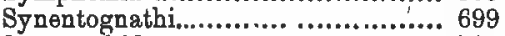

Syngnathida.............................. 702

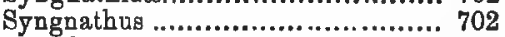

Synodus................................... 689

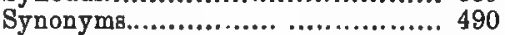

Synopsis of Classification................ 492

Syrnium....................................... 580

T.

tabaccaria, Fistularia................... 703

Tachycineta,............................... 549 
Tadpole Stone Cat..................... 671

tæniatus, Anisotremus................... 735

Tailor Herring............................. 684

Talpidø................................... 498

talpoides, Blarina....................... 496

Tambor ..................................... 768

Tame Duck.............................., 610

Tamias ........................................ 502

Tanagridæ ................................. 547

Tantalidææ.................................. 604

Tantalus ................................... 605

Tarpnm..................................... 683

Tattlers ................................... 595

tau, Batrachus............................. 753

Tautog .................................... 743

Tautoga ................................... 743

Tautogolabrus............................. 743

Tawny Thrush ........................... 571

tchawytcha, Oncorhynchus............ 690

Teal Dacks (et seq.)...................... 611

tectirostris, Sibbaldius (referred to)... 514

Teeter-tail ................................. $5 \varepsilon 6$

Teeter-tiltup (referred to, 561) ........ 596

Teleocephali ................................. 670

Teleostei ...................................... 670

Telestes ...................................... 681

Tell-tale .................................... 594

Temnodon ................................. 720

Tepnessee Warbler........................ 555

Ten-pounder................................... 683

tenuis, Phycis............................. 757

tennirostris, Anguilla.................. 697

teres, Catostomus ......................... 674

Cyprinus......................... 674

Etrumeas........................6, 684

Terns....................................526, 628

terræ-novæ, Scoliodon.................. 661

Terraping ............................638, 639

Tessellated Darter........................ 728

tessellatum, Boleosoma.................... 728

Testadinata ............................. 637

T'etrao ........................................... 584

Tetraodon .................................... 768

Tetraonidæ................................ 584

tetraptnorum, Echeneis................... 709

Tetrasomus................................ 766

Tetrapturus ................................. 711

Tetrodon..............................768, 770

Tetrodontid $\approx$............................. 768

Teuthidæ ................................. 745

Thallasseus caspins ..................... 628

centiacus.................... 629

regius ....................... 628

Thalassidroma wilsoni..................... 624

Thalassochelys............................... 640

thazard, Auxis........................... 712

Thick-billed Guillemot ................ 635

Thimble eye ............................. 712

Thistle Bird.................................. 538

Thread Filefish.......................766, 767
Thread Herring............................ 686.

Three-spined Stickleback............... 704

Thresher..................................... 662

Threeher Sharks........................... 661

thrissa, Opisthonema .................... 686

Thrushes (see Water Thrush, 561)..... 570

Thrynosternum........................... 639

Thryothoras................................. 566

Thunder Snake........................... 647

Thynnus . .................................. 714

thynnus, Orycnas........................ 714

tiburo, Sphyrna...........................6. 661

Tiger Salamander......................... 656

Shark ..............................6 660

Triton............................... 656

Tigoma................................... 681

tigrina, Dendroica........................ 556.

tigrinum, Amblystoma.................... 656

tigrinus, Galeocerdo .....................6.6.6. 660

Tiltup [Teeter-tiltap] (referred to)... 561:

Tinker Mackerel........................... 712

Tip-ap....................................... 596

Titlark ...................................... 564

Titmice ............................................ 568

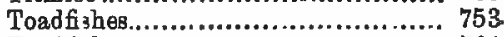

Teadfish........................................ 764 .

Toads ....................................... 652

Tobacco-box.............................. 664

tobianus, Ammody tes..................... 708.

Tomcod .................................... 758

totncodus, Grdus......................... 758

Toothed Minnows........................ 692

Top Minnow ............................. 694

torda, Alca................................. 635

Torpedinidæ............................ 664

Torpedo .................................. 664

torquatus, Colymbus .................... 633

Histrionicus ...................66 617

Tortoises .................................. 637

Totanus ....................................... 594

Toter ... ................................. 674

Towher Bunting.......................... 545.

townendii, Spiza......................... 547

Towneend's Bunting...................... 547

Toxicophis................................... 648

Trachemys................................ 639

Trachurops ............................. 715

trachurus, Gasterosteus................... 705

Trachynotus............................. 718

trachyrhynchus, Pelecanus............. 622

Trachyurus ............................. 673

tractus, Acanthurus (referred to).... 716

traillii, var. of Empidonax pusillus.. 527

Traill's Flycateher....................... 527

Tree Sparrow...........................540, 543

Swift................................ 641

Toads ................................ 650.

triacanthus, Stromateus................... 721

triangulus, var. of Ophibolus doli-

atus ................................. 647 
tribulus, Prionotus...................... 751

tridactyla, Rissa............................ 620

trichas, Geothlypis....................... 562

Trichiuridn ................................... 711

Trichiurus .................................... 711

Trichodiodon ............................... 768

tricolor, Phalaropus....................... 587

Trigger-far, raficollis, Ardea......... 608

Trigla........................................ 751

Triglidø.................................... 751

Trigonidw ................................. 665

Trigonocepbalus ........................... 648

Tringa .................................... 591

Tringoideg ................................. 596

Trionychidæ............................. 640

triseriatus, Chorophilus................... 652

Trisotropis............................... 733

tristis, Spinus............................... 538

Triton ................................652, 656

Troshilidæ................................ 524

Trochilus ................................... 524

Troglodytes ................................. 566

Troglodytidæ ............................. 664

troile, Uria .............................. 635

Tropidoclonium ............................. 644

Tropidonotus...........................643, 644

Tropidolepis ...............................6 641

Trout.. ..................................... 691

Trout Perch.. .................................. 691

Pickerel ........................... 695

trudeaui, Sterna............................. 629

'Trudeau's Tern............................ 629

True Dolphin.............................. 515

True, Fred. W.......................... 516

Trumpeter Swan.........................6.621

Trumpet. fish ................................ 703

truncata, Belone.......................... 699

Trunk-back Turtle....................... 640

Trunkfighes ................................... 765

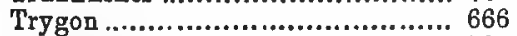

Tryngites.................................... 596

techegrava, Sterna ........................ 628

Tubinares .................................. 623

Tufted Titmouse......................... 569

Tunny......................................... 714

Turbot....................................... 760

Turdidø .................................. 570

Turdus ........................................ 570

targidus, Tetrodon ........................ 768

Turnstone ................................... 600

Turkey Buzzard ............................ 573

Vulture............................ 573

Turkeys ................................... 586

Tursio ...................................... 515

tursio, Tursiops........................... 515

Tursiops................................... 515

Turtles ..................................... 637

Turtle Dove .............................. 583

Two-colored Salamander............... 656
Two-spined Stickleback ............... 704

Two-striped Salamander................ 654

Tylosurus ................................. 699

Tympanuchos ............................ 585

Tyrannidæ ............................... 525

Tyrannus.................................... 526

tyrannus, Alosa............................. 684

Anguilla...................... 697

Brevoortia................... 686

Clupea ............................ 686

Milvulus...................... 525

Tyrannus..................... 526

Tyrant Flycatchers...................... 525

\section{U.}

ulula, Surnia,......................... 582

umbellus, Bonasa .......................... 585

Umbra......................................... 695

Umbridæ.................................... 695

Umbrina .................................... 741

umbrosus, Esox............................ 696

undulatus, Micropogon................. 740

Sceloporus ................... 641

Ungulata ................................... 513

unicolor, Bryttas........................... 726

Unicorn-figh ............................... 767

unicornie, Oitharichthys................. 760

unifasciatus, Hemirhamphus........... 7 $\mathrm{CO}$

Upland Plover............................... 596

Upsilonphorus ................................... 746

Uranidia ........................................ 749

Uranoscopide ............................ 746

Uria ............................................ 635

Urinitorid $¥$.................................. 633

Urinator ................................... 633

Urophycis..................................... 756

Uropsetta ................................. 751

Ursidø ........................................... 512

Ursus ......................................... 512

Urocyon..................................... 509

Urodela..................................... 652

ustulatus, var. swainsonii, Turdus.... 571

\section{V.}

valisneria, Aythya .................... 614

vampyrus, Cephaloptera ................ 667

varia Mniotiltaptera................. 667

variatus, Pœcilichthys..................... 729

Varied Thrush............................ 572

variegatus, Antennarius................. 764

Cyprinodon ................... 692

varius, Sphyrapicus ..................... 519

Veery .................................... 571

velifer, Carpiodes ........................... 674

velox, Accipiter........................ 574 
Velvet Scoter............................. 618

velvetina, Melanetta...................... 618

venenosa, Amblystoma ................. 656

vermiculatus, Esox...................... 696

vermivorus, Helmitherus............... 554

vernalis, Clupea........................... 684

Cyclophis....................... 646

Scomber ........................ 712

versicolor, Abramis..................... 681

Hyla ...........................6 650

Quiscalus ..................... 535

Stenotomus ................ 737

Vertebrata .............................. 494

verticalis, Tyrannus...................... 526

Vesper Sparrow ......................... 542

Vespertilio ................................ 495

vespertilio, Malthe....................... 765

Vespertilionid $\approx$............................ 494

Vesperugo ............................... 495

vigorsii, Dendroica......................... 559

villosus, Dryobates...................... 518

vinciguerræ, Exocœetus.................. 701

Viper.......................................... 643

virens, Contopus......................... 527

Dendroica ...................... 559

Gadus .............................. 758

Icteria ............................... 562

Vireo....................................... 552

Vireonidæ .................................. 552

Vireosylvia ................................. 552

virescens, Ardea .......................... 608

Rana........................... 649

virginea, Cistado.............................. 637

virginiana, Didelphys................... 517

virginianus, Acanthocottus............ 749

Bubo ....................... 581

Cardinalis .................. 545

Cariacus..................... 513

Chordeiles................... 523

Colinus....................... 584

Rallus ....................6 601

Virginia Deer................................ 513

Rail ............................... 601

virginicus, Charadrius.................... 597

Pomadys ........................ 735

viridescens, Diemyctylus.................. 625

Osmerus ..................... 689

viridis, var. of Hyla versicolor ....... 651

viscosa, var. of Uranidea richard-

soni...................................... 749

vison, Putorius............................ 510

Viscid Salamander.......................... 654

vitreum, Stizostedium.................. 731

vittatas, Engraulis..................... 688

vitulina, Phoca.......................... 508

viviparus, var. of Sebastes marinus., 748

vocifora, Eg gialitis....................... 598

vociferus, Antrostomus.................... 523

volans, Sciuropterus....................... 501

volitans, Cephalacanthus................. 732 volitans, Exoccetus ...................... 701

volucella, Sciuropterus................... 501

Vomer....................................... 717

vomer, Argyreiosus...................... 717

Selene ........................... 716

vomerinus, Anarrhichas............... 755

vulgaris, Acanthias....................... 659

Amiurus ...................... 672

Anguilla ...................... 698

Anxis ............................ 712

Brosmius ...................... 757

Conger ...........................6 698

Hippoglossus.................. 761

Mustelus ........................ 660

Pomotis........................ 727

Sphyræna .................. 707

Thynnus........................ 714

Vulpes ........................................ 503

vulpes, Albula.............................. 682

Alopias............................ 662

Vulpes............................... 508

vulpinus, Coluber....................... 646

Vulturidæ ..................................... 573

Vultures ................................ 573

W.

Wading Birds........................... 587

Wagtails ..................................... 564

.Wake-up ................................ 521

Wall-eyed Pike........................... 731

Warbling Flycatcher..................... 553

Warblers Vireo.......................... 553

Water Adder.................................. 643

Lizard ............................. 653

Snake ............................... 643

Thrush ............................... $56^{3} \mathrm{l}$

Turtle. ............................. 637

Wagtail.......................... 561

Witch ............................. 632

Wax-wings ............................ 550

Weakfish ..................................... 741

Weasels ..............................509, 510

Western Sandpiper....................... 593

Whalebone Whale....................... 514

Whales....................................... 514

wheatlandi, Gasterosteus............... 704

Whistler.................................... 615

Whistling Swan.......................... 620

Whip poor-will.............................. 523

Whitebait ................................ 684

White-bellied Nuthatch.................. 568

Sapsucker ................. 568

Swallow .................... 549

White.breasted Nuthatch................. 568

Sapsucker ............... 568

White Catfish............................. 672

White crowned Sparrow:................ 542 
White-eyed Flycatcher.................. 553

Whitefish Vireo ....................... 553

White-footed Moure........................ 505

White-fronted Goose...................... 619

White Hake.............................. 757

Heron .............................6 607

Mullet............................ 706

Perch ............................. 732

Rabbit ........................... 507

White-rumped Sandpiper................ 591

Shrike ................. 552

White Sucker.......................674, 675

White-tailed Remora................... 709

White-throated Sparrow.............. 543

Warbler ............... 555

White-winged Blackbird................ 547

Coot........................6 618

Crossbill ................ 538

Gull ....................6 626

Scoter......................6 618

Surf Duck............... 618

Whiting .................................. 741

Wild cat ......................................... 508

Wild Goose............................... 620

Pigeon.............................. 583

Turkey............................. 586

Willet..................................... 595

wilsonia, Agialitis...................... 598

wilsonianus, Asio........................ 579

wilsoni, Gallinago....................... 589

Steganopus ................... 587

Sterna .........................6 629

Thalassidroma .................6 624

Wilson's Petrel........................... 624

Phalarope..................... 587

Plover............................ 598

Snipe.......................... 589

Tern .........................6.629 629

Thrush......................... 571

Warbler......................... 563

Window-pan $\theta$.............................. 760

Winter Falcon............................... 576

Flounder.......................... 762

Wren .............................. 567

Wolf (referred to

Wolf-fish...................................... 755

Woodehuck ................................. 502

Woodcock................................. 589

Wood Duck.................................. 614

Ibis ............................... 605

Woodpeckers.............................. 518

Wood Pee-wee............................... 527

Rat ............................... 505

Terrapin ............................ 638

Thrugh ............................ 570

Tortoise............................ 638

Warblers........................... 554

Wren ................................. 566
Worm-eating Swamp Warbler........ 554

Wrasees.................................... 742

Wrens .......................................... 564

Wren........................................ 569

X.

Xanthocephalus......................... 532 xanthocephalus, Xanthocephalus.... 532 zanthurus, Homoprion .................. 739

Liostomus.................. 740

Xema ..................................... 628

Xenisma .................................. 693

Xiphias ........................................ 710

Xiphiidm................................ 710

$\mathbf{Y}$.

Yarup .................................. 521

Yellow-bellied Flycatcher.............. 528

Sapsucker .............. 519

Woodpecker ............ 519

Yellow-billed Cuckoo ................... 522

Yellow Bird............................... 538

Yellow-breasted Chat...................... 562

Yellow Caranx......................... 715

Catfish ........................... 672

Desmograth ........................ 653

Yellow-finned Red-mouth.............. 735

Yellow Hammer ....................... 521

Yellow-headed Blackbird ............... 532

Yellow-legs ................................. 594

Yellow-masked Warbler ................ 563

Yellow Mocker .......................... 563

Yellow Palm Warbler..................... 560

Perch........................... 731

Pike............................ 731

Rail .................................., 602

Redpoll Warbler................ 560

Yellow.rumped Warbler ................ 557

Yollow shanks ............................... 594

Yellow Stone Cat ....................... 671

Yellow-tail.. ........................686, 717

Yellow-tail Perch......................... 739

Yellow-throated Flycatcher ........... 553

Vireo................. 558

Warbler ............... 559

Yellow Tritori............................. 655

Warbler .......................... 556

Yollow-winged Sparrow................ 541

Yelting ...................................... 734

Yucker ..................................... 521

Z.

Zamelodia..,............................... 546

Zapodidæ ................................ 503 
Zapts .................................... 503 zebra, Fundulus.............................693 693 Zenaidura ..................................... 583 Zeus.......................................716, 744 zibethicus, Fiber................................ 506 Zoarces........................................ 755 zonata, Sêriola........................718, 719 zonatus, Ephippus ........................ 744

Zonichthys ................................... 719

Zonotrichia .................................. 542

zygæna, Sphyrna............................ 661

Zygonectes ................................. 694 





